\title{
The Image of the Latins in Late Byzantine Epistolography
}

\author{
by
}

Zoltán Szegvári

Supervisors: Prof Dr. Terézia Olajos (SZTE, †2018), Prof. Dr. Tibor Almási (SZTE)

External consultant: Prof. Dr. Anderas Rhoby (ÖAW) 
I, the undersigned, Zoltán Szegvári, candidate for the PhD degree in History, declare herewith that the present thesis is exclusively my own work, based on my research and only such external information as properly credited in notes and bibliography. I declare that no unidentified and illegitimate use was made of the work of others, and no part of the thesis infringes on any person's or institution's copyright. I also declare that no part of the thesis has been submitted in this form to any other institution of higher education for an academic degree.

Szeged, 10 September 2020

Signature 


\section{Table of Contents}

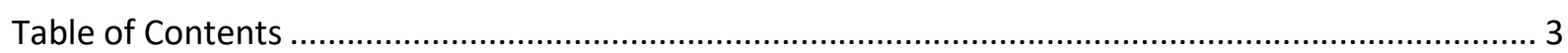

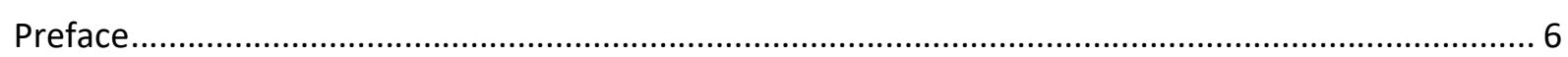

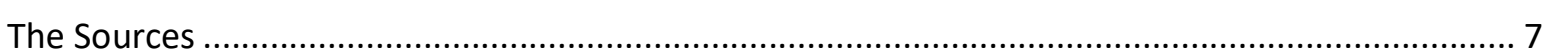

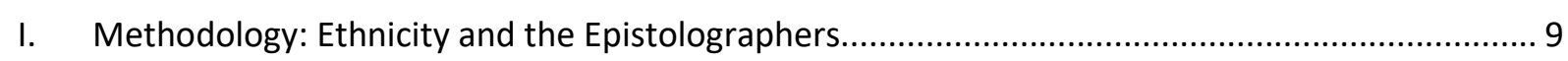

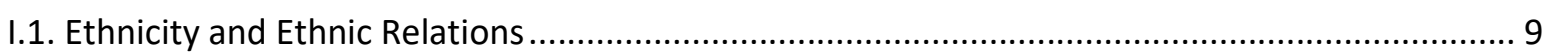

I.2. Greco-Roman and Byzantine Epistolography: Antique and Modern Letter-Theories ................. 12

II. Violent Conflict between the Latins and the Byzantines .......................................................... 18

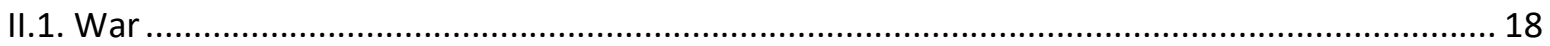

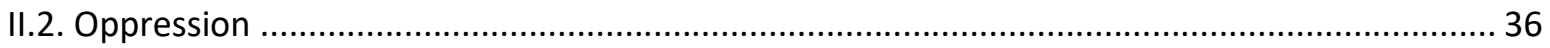

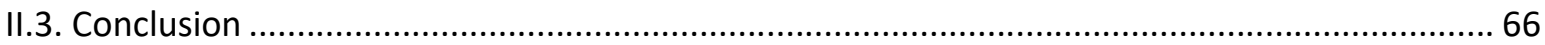

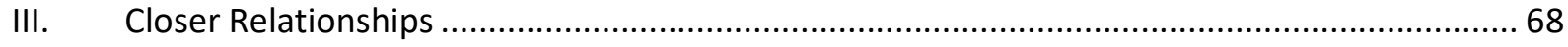

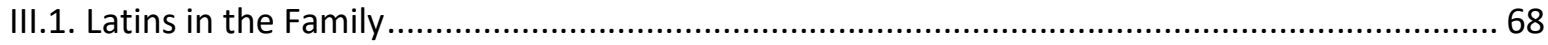

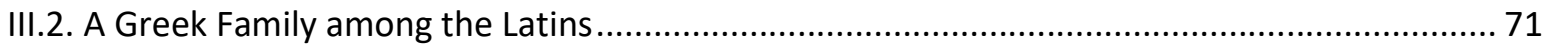

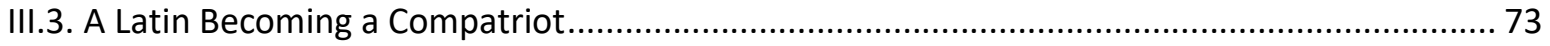

III.4. His Imperial Majesty and the Latin Petitioners .................................................................... 75

III.5. An Appeasing Embassy that Failed Remarkably ...................................................................... 76

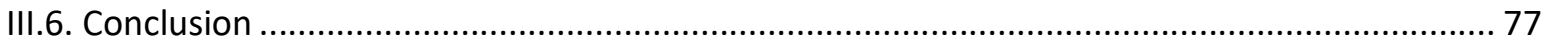

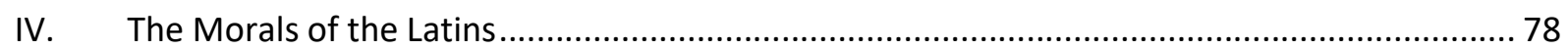

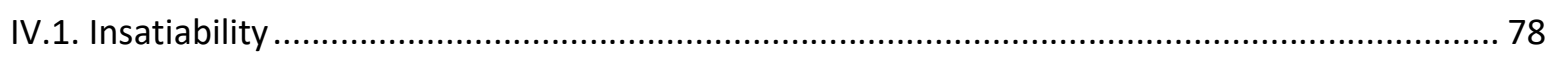

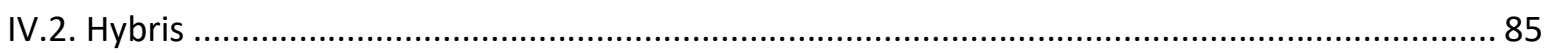

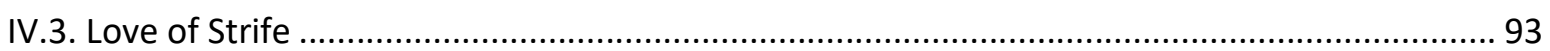

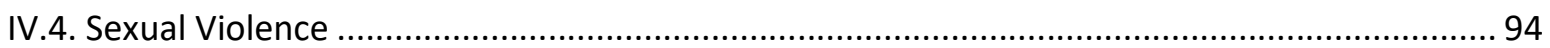

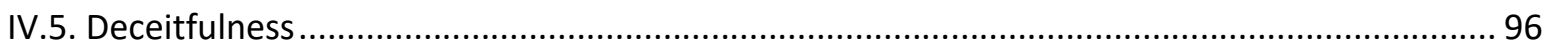

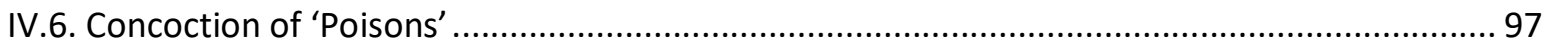

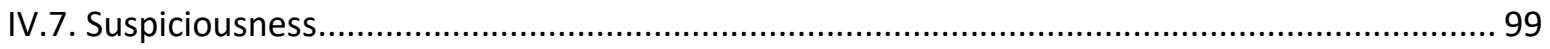

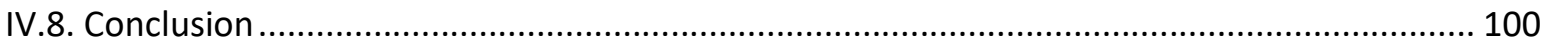

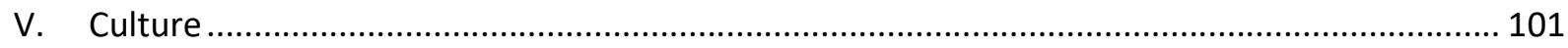

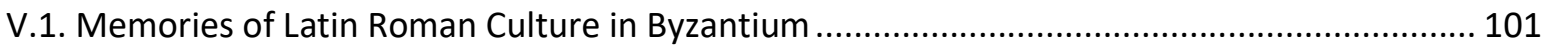

V.2. A Taste Most Questionable? Latin Textiles Worn by Byzantine Citizens ................................ 104

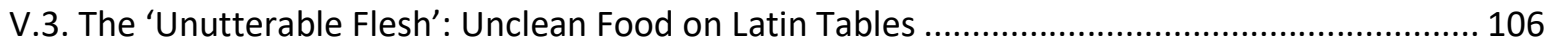

V.4. No Latin should rule over any Roman ... for a Different Level of Culture? ............................. 107

V.5. 'A Return of the Vandals?' Uncivilised Latins Endangering Byzantine Culture........................ 108 


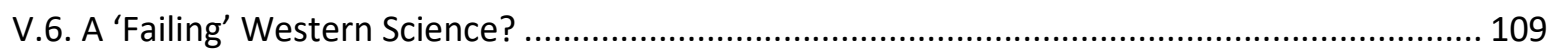

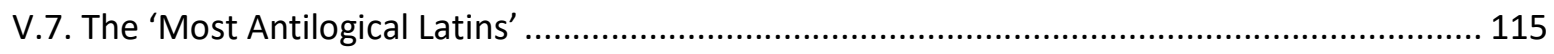

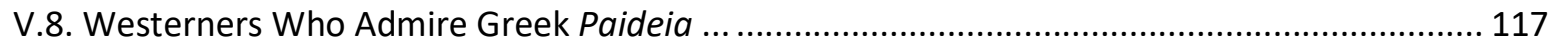

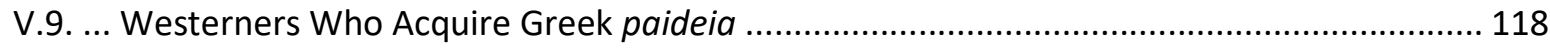

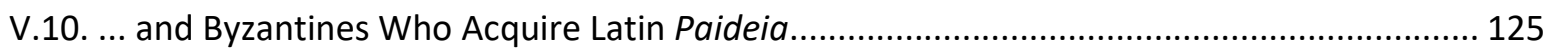

V.11. The Charge of the Cultural Decline of the Greeks.............................................................. 130

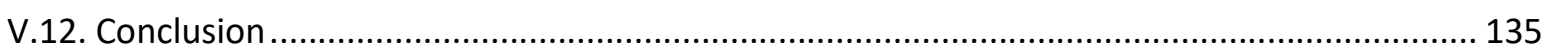

VI. Religious Subjects Occasionally Present in the Letters ..................................................... 136

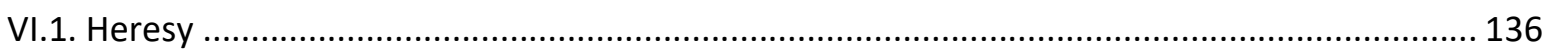

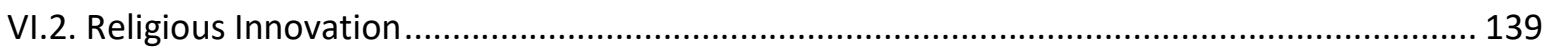

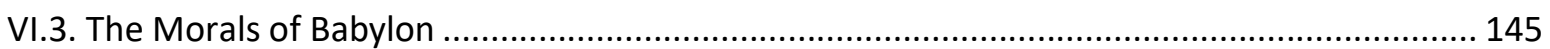

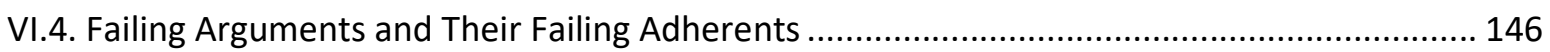

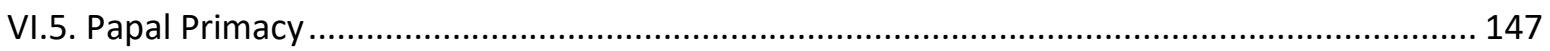

VI.6. A Church Union Built upon Far Too Material Grounds? ....................................................... 149

VI.7. Obscurant Rejection of the Latin 'Religion' and 'Sacrifices'............................................... 150

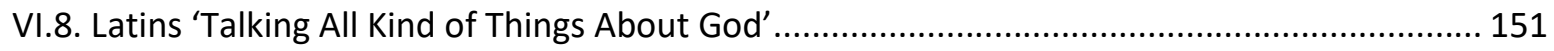

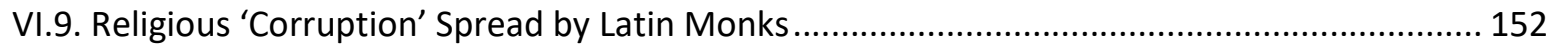

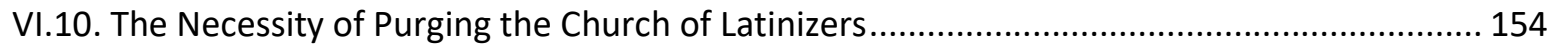

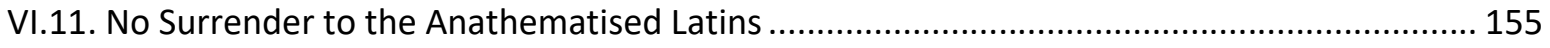

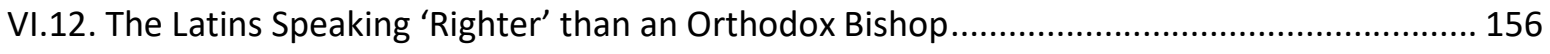

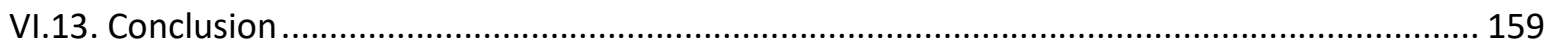

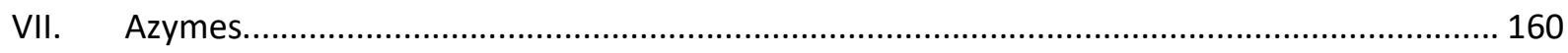

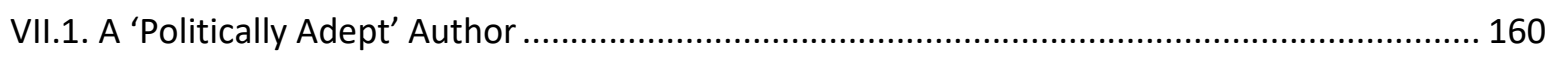

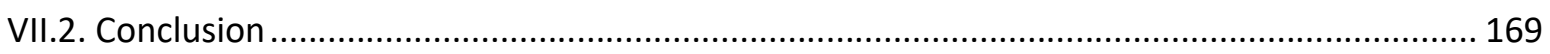

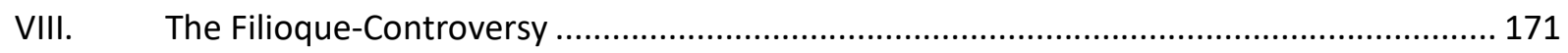

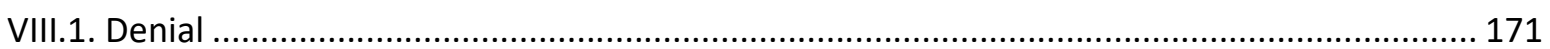

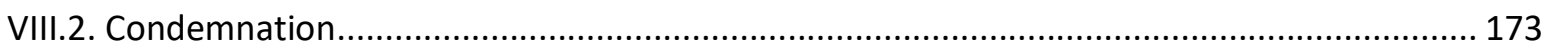

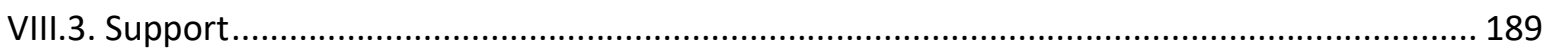

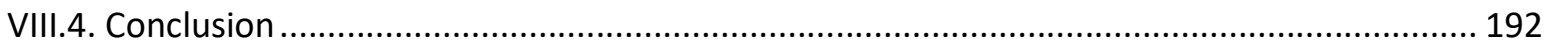

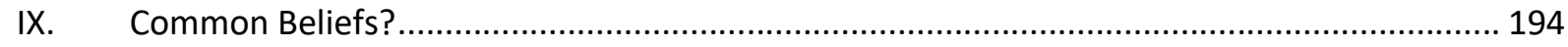

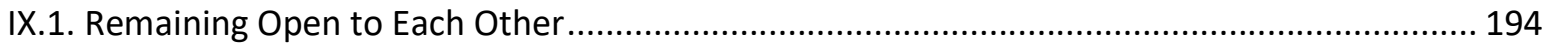

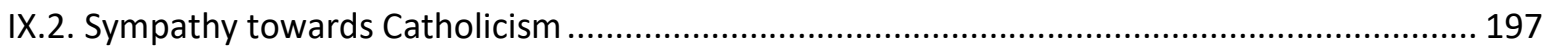

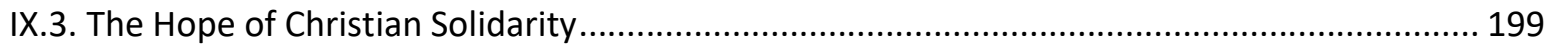

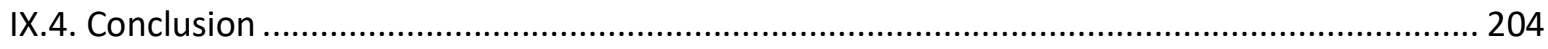

X. Summary

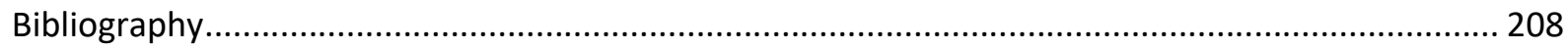


Text Editions .

208

Lexica Grammatica .

213

Secondary Literature

213 


\section{Preface}

This study investigates the image of the Latins in Late Byzantine epistolography. There is more than one reason for choosing this subject for the thesis. First of all, the events of the Fourth Crusade caused an enormous change in Byzantine-Latin relationships, influencing them until the end of the Empire and affecting the relationship between Western and Eastern Christendom even nowadays. Therefore, the question of Byzantine perceptions of the Latins has substantial importance. Second, the image of the Latins in Byzantine culture has been the subject of numerous major studies, examining, for example, historiographical sources, ${ }^{1}$ catalogues of the Latins' perceived religious 'errors', ${ }^{2}$ hagiographical works, ${ }^{3}$ and ethnographic discourses. ${ }^{4}$ However, epistolography proved to be a neglected group of sources, not independently from the stereotype of Byzantine epistolography being verbose and at the very same time containing little if any exact information. ${ }^{5}$

Following the preface, a short description of the analysed sources will be presented. After that, the methodology of the research is described. This part intends to cover both the anthropological and epistolographic background of the present study. The next chapter will discuss the subject of violent conflicts between Latins and Byzantines represented in Late Byzantine epistolography. Thereafter, the representation of closer contacts between Latins and Byzantines will be examined.

The next section will address the polemics on Latin morals, with their perceived parallels and positively or negatively evaluated differences in comparison to contemporary Byzantine morality. This chapter will be followed by a discussion of the perception of Latin cultural niveau and Latin relationship with Byzantine culture in the epistles. In the following chapter, the main topic will be Latin material culture and its representation in the sources.

After these chapters, the study will turn to the field of religion. Within that wide category, the first issue to be discussed will be the descriptions of the Catholic use of azymes,

\footnotetext{
1 PAGE, Gill: Being Byzantine. Greek Identity before the Ottomans. Cambridge, UK; New York, Cambridge University Press, 2008. Henceforth PAGE 2008

${ }^{2}$ KolBABA, Tia M. The Byzantine Lists: Errors of the Latins. Illinois Medieval Studies. Urbana: University of Illinois Press, 2000. Henceforth KolBABA 2000

3 Hinterberger, Martin: A Neglected Tool of Orthodox Propaganda? The Image of the Latins in Byzantine Hagiography. In HINTERBERGER, Martin - SCHABEL, Chris (Eds.): Greeks, Latins and Intellectual History 1204-1500. Leuven - Paris - Walpole, MA, Peeters, 2011, pp. 129-149. Henceforth HINTERBERGER 2011

${ }^{4}$ KALDELLIS, Anthony. Ethnography after Antiquity: Foreign Lands and Peoples in Byzantine Literature. Empire and After. Philadelphia: University of Pennsylvania Press, 2013. Henceforth KALDELLIS 2013

${ }^{5}$ HATLIE, Peter. 'Redeeming Byzantine Epistolography'. BMGS, no. 20 (1996), pp. 213-48, pp. 215-216.
} 
unleavened bread, in the Eucharist, preserved in the letters. It will be followed by depictions of the Filioque, that is, the Catholic teaching on the origins of the Holy Spirit. Remarks on theological subjects uncommon in the analysed letters provides the subject of the following

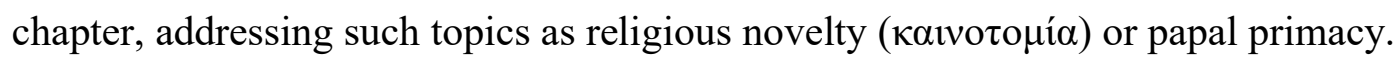

Thereafter, the study will turn to opinions regarding the existence of common points between the Catholic and the Orthodox denominations, voiced in the letters. This chapter involves topics ranging from Catholic sympathies among the authors to hopes for Christian solidarity against the Ottoman threat. The study will end with a summary of its results. Besides that, each chapter will have its own, separate conclusion at its end.

\section{The Sources}

The sources used in the study are epistolographic works, that is, letters. In 1981, Margaret Mullet estimated the number of extant major letter-collections from the Byzantine era to be around 150, and the total number of surviving letters to be approximately $15.000{ }^{6}$ Michael Grünbart, in his 2001 collection, the Epistularum Byzantinarum Initia, counted 15.480 extant Byzantine letters. ${ }^{7}$ These numbers, especially in parallel with the much lower number of surviving works in other genres, mirror a remarkable popularity of letter-writing in Byzantine society.

The thesis is based upon selected letters written by Byzantine epistolographers. From the 33 authors involved, only letters that can be relatively certainly dated to the period between 1204 and 1453 are used for the study, as its aim is to analyse the image of the Latins represented in Late Byzantine Epistolography. The letters are selected upon seemingly rather simple criteria: first, they have to mention a Western ethnic group by ethnonym, or by the collective term 'Latin', and second, they have to voice some kind of opinion regarding the general characteristics of this certain Western group. This opinion may be an elaborate description of a perceived characteristic trait of the group, a short remark on them, or an implicit judgmen, that can be deciphered from the text.

These criteria are needed because the study aims to analyse generalising representations of the Latins, which can only be examined if there is 1) a clear designation of

\footnotetext{
${ }^{6}$ MulLETT, Margaret: The Classical Tradition in the Byzantine Letter. In MuLLETT, Margaret - SCOTT, Roger (Eds.): Byzantium and the Classical Tradition. University of Birmingham Thirteenth Spring Symposium of Byzantine Studies, 1979. Centre of Byzantine Studies, University of Birmingham, 1981, pp. 75-93. Henceforth MULLETT 1981

${ }^{7}$ GRÜNBART, Michael: Epistularum Byzantinarum Initia. Hildesheim et al., 2001, p. 4. Henceforth Grünbart 2001A
} 
ethnicity and 2) the description clearly points beyond judgment on the properties of an individual person. 


\section{Methodology: Ethnicity and the Epistolographers}

This analysis of the image of the Latins represented in Late Byzantine epistolography relies on an interdisciplinary theoretical framework, utilizing the methods of cultural anthropology and literary science. The reason for this is that the sources of the study involve three major issues, and two of them can be addressed most competently by the methods of the above-mentioned scientific disciplines. These issues are 1) the texts under investigation are historical sources, created within the cultural context of the Byzantine civilisation, 2) the sources present the researcher with the issue of ethnicity, particularly ethnic identity and ethnic relations, which favours the application of cultural anthropological methods, 3) they were created within the framework of Byzantine epistolography, making literary approaches towards epistolography relevant. An introduction to the cultural anthropological method and the understanding of epistolography used in this thesis are necessary and they will be presented in the followings.

\section{I.1. Ethnicity and Ethnic Relations}

Refreshingly, an increasing number of works have been published on ethnicity in Byzantium in recent years. These include, beside the book of Gill Page on Byzantine identity ${ }^{8}$ studies of Ioannis Stouraitis ${ }^{9}$, Johannes Koder $^{10}$, Claudia Rapp ${ }^{11}$, Christos

\footnotetext{
${ }^{8}$ See note 1.

${ }^{9}$ STOURAITIS, Ioannis Roman Identity in Byzantium: A Critical Approach. BZ 107/1 (2014), pp. 175-220; STOURAITIS, loannis: Reinventing Roman Ethnicity in High and Late Medieval Byzantium. Medieval Worlds Comparative \& Interdisciplinary Studies, no. 2017/5 (n.d.), pp. 70-94; STOURAITIS, Ioannis: Byzantine Romanness: From Geopolitical to Ethnic Conceptions. In Transformations of Romanness in the Early Middle Ages: Early Medieval Regions and Identities, pp. 123-39, n.d.

${ }^{10}$ KODER, Johannes, Byzantium as Seen by Itself - Images and Mechanisms at Work, in: Proceedings of the 22nd International Congress of Byzantine Studies Sofia, 22-27 August 2011, I. Plenary Papers (Sofia, 2011), pp. 69-81. 11 RAPP, Claudia, Hellenic Identity, Romanitas, and Christianity in Byzantium, In: ZACHARIA, Katerina (ed.), Hellenisms. Culture, Identity and Ethnicity from Antiquity to Modernity (Aldershot, 2008) pp. 127-147.
} 
Malatras $^{12}$, and Ioannis Smarnakis ${ }^{13}$, just like the thought-provoking, but also heavily criticised works of Anthony Kaldellis, ${ }^{14}$ using different approaches to discuss this topic.

In this investigation, ethnicity and relationships between ethnic communities will be analysed utilising the approach to ethnicity introduced by Fredrik Barth and developed further by Thomas Hylland Eriksen, which is an established approach within cultural anthropology. In the Barthian model, ethnic communities should be regarded as ascriptive categories. Ethnicity is a group identity based on the subjective belief of the individual in the existence of a certain group, the belonging of the individual to the group, and usually, discernible cultural traits (language, religious practice, material culture, etc.) are used to define it by the members and to justify its distinctive nature. ${ }^{15}$

In fact, however, it is not the cultural content that is the central factor in the existence of an ethnic community, but the boundary that encloses the group, separating it from other ethnic groups. Thomas Hylland Eriksen used the Zen Buddhist paradox of one hand clapping to demonstrate the key role of the boundary with other communities in defining and perpetuating the existence of an ethnic group. ${ }^{16}$ Contact with other communities increases the awareness of the boundary and the aforementioned observable cultural markers, but does not necessarily lead to their reinforcement.

Ethnic boundaries are negotiable constructs, subjects to constant redefinition under the circumstances. ${ }^{17}$ Contact with a certain group, perception of 'similarity' and belief in a mutually advantageous relationship may make these boundaries highly permeable towards this group, while at the same time boundaries can prove to be solid and definitely exclusive towards another group, on the basis of a perceived 'alienity' and interaction seen as competitive and threatening to the prosperity or the perpetuation of the group defined by them. ${ }^{18}$

\footnotetext{
12 Malatras, Christos, The Making of an Ethnic Group: The Romaioi in the 12th-13th Centuries, in DIMADIS, Konstantinos A. (ed.), Identities in the Greek World (From 1204 to the Present Day), Proceedings of the 4th European Congress of Modern Greek Studies Granada, 9-12 September 2010 (Athens, 2011) pp. 419-430.

${ }^{13}$ SMARNAKIS, Ioannis, Rethinking Roman Identity after the Fall (1453): Perceptions of >Romanitas by Doukas and Sphrantzes, Byzantina Symmeikta 25 (2015), pp. 211-234.

${ }^{14}$ KALDELLIS, Anthony, From Rome to New Rome, from Empire to Nation-State: Reopening the Question of Byzantium's Roman Identity, in Lucy Grig and Gavin Kelly (eds.), Two Romes: Rome and Constantinople in Late Antiquity (Oxford, 2012), pp. 387-404.

${ }^{15}$ BARTH, Fredrik: Introduction. In BARTH, Fredrik (Ed.): Ethnic Groups and Boundaries. The Social Organisation of Cultural Difference. Bergen, Universitetsforlaget, 1969, pp. 11-13. Henceforth BARTH 1969

${ }^{16}$ ERIKSEN, Thomas Hylland. Ethnicity and Nationalism: Anthropological Perspectives. Anthropology, Culture, and Society. London, Boulder, Colo: Pluto Press, 1993, p. 9.

17 BARTH 1969, pp. 32-35.

${ }^{18}$ ERIKSEN 1993, pp. 38-39.
} 
A question that logically arises is whether the concept of ethnicity is applicable for pre-modern societies, which existed before the development of modern nationalism, and with their identity accessible only through extant historical sources. This study regards it as an applicable model, building on the criteria stated by Gill Page in her monograph on Byzantine identity represented in Byzantine historical works. As Page argues, such a model should concentrate on "(1) subjective self-ascription within the context of a group, (2) perceptible criteria by which membership of a group may be expressed or defined and (3) the impetus to ethnic group formation provided by the awareness of difference from other groups and particularly the need to maintain a border against other groups perceived as a threat to one's own group's survival or prosperity."19

Another theory that is used in this dissertation is the crucial role of ethnic crisis in the formation of identities, proposed by nationalism- and identity-researcher Anthony D. Smith. Smith, writing on the resurgence of ethnic conflicts in Europe during the 1980s, stressed the role of ethnic crisis, i.e. a substantive threat to prosperity or existence of an ethnic community, in the birth of modern nationalism and the formation of ethnic identities, including its important effect on the development of ethnic criteria, demonstrating the process with the example of the Bosnian ('Muslim') minority in former Yugoslavia. ${ }^{20}$ As the Latin conquest of former Byzantine heartlands and the consequences of Latin rule can be defined as a serious and prolonged ethnic crisis for Byzantine Greeks, obviously provoking answers from their side, so the theory is applicable to the subject and may have its benefits for the thesis.

In the following part, approximately 150 extant letters written by 33 Byzantine intellectuals, leaving behind collections of letters, in the period from 1204 to 1453, will be analysed. The study will concentrate on different content elements. First of all, it will involve the identification of the standard, classicising ethnonyms used for Westerners by the Byzantines in the sources. Moreover, it will identify key topics, traditionally linked to the Westerners in Byzantine literature, such as the use of unleavened bread (azymes) in the Eucharist, or military prowess. The third step is the identification of the subjective opinion voiced explicitly or suggested implicitly on the topic by the author.

The latter is the most complex stratum of the material. Authors may voice simple or rather nuanced views on a subject, and they can change their attitudes during their lifetime. Furthermore, our sources are letters, intended to be read by an audience with its own worldview and reactions to certain views, all of which are presumable by the author, so the

\footnotetext{
19 PAGE 2008, p. 20.

${ }^{20}$ SMITH, Anthony D.: The Ethnic Origins of Nations. Oxford, 1986, pp. 23-29.
} 
situation may influence the opinion that is voiced by a letter. This is the reason why epistolography, and especially the norms of Greco-Roman epistolography, are so important for the study.

\section{I.2. Greco-Roman and Byzantine Epistolography: Antique and Modern Letter-Theories}

Before analysing the sources at any depth, it is necessary to discuss certain aspects, which are connected to their genre, the letter itself. First, the concept of the letter used for the study must be clarified. After that, the field of Greco-Roman, and relating Byzantine, lettertheories deserves an introduction, in order to understand the complex theoretical background of the genre that heavily influenced, and, in many cases, even determined how the selected authors wrote their respective letters. Finally, their social function should be described briefly, because of the effect it potentially had on the opera.

Epistolographic theory did not always focus on the same aspects as above. The oldest extant source on the subject from the Greco-Roman world is known as De elocutione and is attributed to a certain Demetrios. Tradition erroneously identified the author with Demetrios Phalerinos, a student of Aristotle, but this assumption was later proved to be false and very little is certain about his person. Scholarly consensus dates the work to the mid-second century B.C. The main concerns of the work are with the characteristics of good letterwriting, teaching the reader how to emulate them and how to recognise them in letters written by others. $^{21}$

Demetrios compares the letter to a dialogue, but stresses the differences between dialogue and letter, which arise from the different communicative situation. The main attributes of a good letter are brevity (228), avoidance of inappropriate topics (230), clarity (231) and beauty (232), using a combination of the elegant and plain styles (234). ${ }^{22}$

However, not only the Greek-speaking world produced works on this subject. The first surviving treatise in Latin which deals with letter-writing in detail is an appendix of a rhetorical work, the Ars rhetorica (The Art of Rhetoric), attributed to Caius Julius Victor. Julius Victor discusses epistolography as a genre within the field of rhetoric, and, similarly to

\footnotetext{
${ }^{21}$ Malherbe, Abraham: Ancient Epistolary Theorists. Scholars Press, Atlanta (Georgia), 1988. p. 2.

${ }^{22}$ Halliwell, Stephen - Fyfe, W. Hamilton - Innes, Doreen C. - Roberts, W. Rhys (Transls.): Aristotle, Longinus, Demetrius. Poetics. Longinus: On the Sublime. Demetrius: On Style. Revised by Donald A. Russell. Loeb Classical Library 199. Cambridge, MA: Harvard University Press, 1995, pp. 480-483.
} 
Demetrios, focuses on epistolary style and the effect of the letter on the recipient. The text makes a distinction between letters written to superiors, equals and inferiors, discourages the application of complex rhetorical structures, while highlights the importance of grace and clarity. $^{23}$

Unlike the previous texts, a work extant in two different versions, one attributed to Libanios and one to Proklos, bearing the title De forma Epistolari (On Letter Form), shows a much greater preoccupation with subgenres within epistolography, identifying forty-one

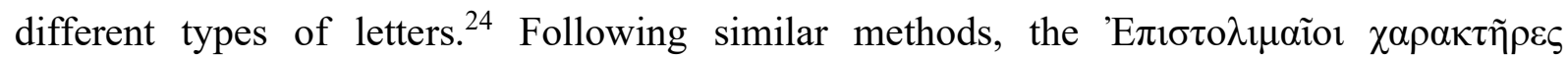
distinguishes twenty-one, while the Tútor 'E Demetrios identifies twenty-one distinct letter-types. ${ }^{25}$

Maybe the most influential Late Antique theoretician of letters was, however, a theologian, Gregorios Nazianzenos. Gregorios, one of the so-called Cappadocian Fathers, provided a brief and easily understandable guide in a letter, written to give advice to his grand-nephew, Nikoboulus. Gregorios expounds that a letter-writer must keep three important

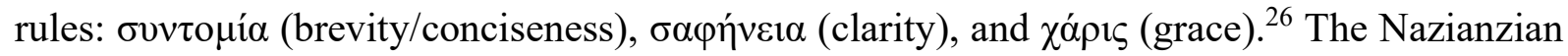
guidelines determined Byzantine letter-writing until the fall of the Empire. ${ }^{27}$

Modern theoretical research on Greco-Roman epistolography began in the field of New Testament Studies, initially with a primary focus on the Pauline Epistles. Gustav Adolf Deissmann, a New Testament scholar attempted to give a more solid scientific basis for studies of Early Christian letter, resulting in a new theoretical approach to Greek and Roman letters. Deissmann divided the letters of Late Antiquity into two main categories: 'real letters' and 'epistles'. Following his interpretation, a real letter is private, related to direct

\footnotetext{
${ }^{23}$ Halm, K. (ed.): Rhetores Latini minores. Leipzig, Teubner, 1863. pp. 447-448.

${ }^{24}$ Forster, R.: Libanii opera X-XI. Leipzig, Teubner, 1921-22. On the role of Libanios in the Greco-Roman rhetorical tradition, see CABOURET, Bernadette: Libanius' Letters. In VAN Hoof, Lieve (Ed.): Libanius: A Critical Introduction. Cambridge University Press, 2014, pp. 144-159.

${ }^{25}$ WeICHERT, V (ed.): Demetrii et Libanii quae feruntur 'Typoi epistolikoi' et 'Epistolimaioi characteres'. Leipzig, Teubner, 1910. On their main characteristics, see POSTER, Carol: A Conversation Halved. Epistolary Theory in Greco-Roman Antiquity. In Letter-Writing Manuals and Instruction from Antiquity to the Present. In POSTER, Carol - MitchelL, Linda (Eds.): Letter-Writing Manuals and Instruction from Antiquity to Present. Columbia, University of South Carolina Press, 2007, pp. 21-51.

${ }^{26}$ GallaY, P. (Ed.), S. Gregoire de Nazianze. Lettres. 2 vols. Paris, Budé, 1964-1967; see also Hunger, Herbert: Die hochsprachliche profane Literaur der Byzantiner I. Philosophie-Rhetorik-EpistolographieGeschichtsschreibung-Geographie. München, C. H. Beck'sche Verlagsbuchhandlung, 1978. pp. 199-200.

27 DenNIS, George T.: The Byzantines as Revealed in Their Letters. In DufFY, John - Peradotto, John (Eds.): Gonimos. Neoplatonic and Byzantine Studies Presented to Leendert G. Westerink at 75. Buffalo, New York, Arethousa, 1988, pp. 155-165, esp. 156-159; Rнову, Andreas: Aspekte des Fortlebens von Gregory von Nazianz in byzantinischer und postbyzantinischer Zeit. In GRÜNBART, Michael: Theatron. Rhetorische Kultur in Spätantike und Mittelalter Rhetorical Culture in Late Antiquity and the Middle Ages Berlin - New York, De Gruyter, 2007, pp. 409-418.
} 
communication or serves as a substitute of it, and strictly non-literary, while an epistle is public, artistic, and literary. ${ }^{28}$

Although Deissmann's framework eventually proved to be too rigid and also flawed, but it provoked further research into the topic, having an effect on Byzantine Studies too. In the early 1930s, Ioannes Sykutris started to promote more scholarly attention towards Byzantine epistolography, stressing the necessity of the development of a reliable theoretical framework (until then relying on the categories of Deissmann) and highlighting the literary qualities of Byzantine letters. Sykutris actually argued that Byzantium even 'outranked' its Greek and Roman predecessors in the field of letter-writing. ${ }^{29}$ Unfortunately, his premature death prevented him from pursuing the ambitious goals he proposed.

Discourse on ancient epistolography went through a major change in the 1960s, when notable New Testament scholar William G. Doty openly rejected the framework introduced by Deissmann. Doty found the dichotomy of 'real letter' and 'epistle' false, and suggested a categorization based upon the level of privacy supposed by the respective letters, making distinctions between 'more private' and 'less private' types of letters. Nonetheless, he did not elaborate his system, partly because of his awareness of the difficulties of determining levels of 'privacy'. 30

A different approach, partly inspired by Doty, and devised by Luther Stirewalt, is the three-level system of normative, extended and fictitious level settings. Normative settings are characterized by the sender using his own name, writing to a personally known addressee, in the widest possible range of subjects. Extended settings differ from these in supposition of a wider audience, and not independently from this aspect, the selection of a conventional subject matter. Finally, the key feature of the fictitious settings is the impersonation of another person by the sender. ${ }^{31}$

In spite of all the above-mentioned developments, the history of epistolographic theory should not be understood as a positivistic process, moving towards 'the ultimate solution'. As a detailed analysis by Stanley K. Stowers had demonstrated it just a few years before

28 DeISSMAn, G. A.: Licht vom Osten.Das Neue Testament und die neuentdeckte Texte der hellenistischrömischen Welt. Tübingen, 1923 (1895), pp. 193-208.

${ }^{29}$ SYKUTRIS, I.: Epistolographie, in: Real-Encyclopedie der classischen Altertumswissenschaft, Suppl. 5. Stuttgart 1930, pp. 185-220; SYKUTRIS, I.: Probleme der byzantinischen Epistolographie. In: OrLANDOS, A. C. (Ed.): Actes du IIIme Congrès International d'Études Byzantines (session d'Athènes, octobre 1930). Athènes, 1932, pp. 295310.

${ }^{30}$ DotY, William G.: The Classification of Epistolary Literature. The Catholic Biblical Quarterly 31 (1969), pp. 183199.

${ }^{31}$ In StIREWALT, Luther M. Jr.: The Uses and Development of Greek Letter-Writing through the Second Century C. E. In StIREWALT, Luther M. Jr.: Studies in Ancient Greek Epistolography. Scholars Press, Atlanta, Georgia, 1993, pp. 1-26. 
Stirewalt proposed his system, it is extremely difficult to find a more appropriate theoretical basis than the one of Deissmann, as the genre of letter proved to be highly adaptable in the ancient world, resulting in a wide variety of possible categories with notoriously fluid boundaries. This fact does not make theoretical work on epistolography futile, and should not prevent literary-historical research, but merely necessitates awareness of the problem and more flexible attitudes by theoreticians of the field. ${ }^{32}$

An inspirational example is the one applied by the Byzantinist Herbert Hunger. Hunger, for his research on Byzantine epistolography, differentiated between 'official letter', 'private letter', 'literary private letter' and 'epistle'. This categorisation evidently relies heavily on the system created by Deissmann, and is not without limitations, but was very effective for the research of Hunger, for instance, the study of the role played by the institution of Byzantine theatra in Byzantine epistolography. ${ }^{33}$

Anthony Littlewood, on the other hand, proposed that letters could be regarded not merely as historical sources, but artistic products as well, and thereby, they could be examined as literary works. Littlewood, in accord with this approach, concentrated primarily on the analysis of style, identifying elements of the display of erudition in Byzantine letters, ${ }^{34}$ and the technics of the representation of their own personality by the authors in their works. ${ }^{35}$

Another methodological approach, heavily influenced by sociology, was demonstrated by Margaret Elisabeth Mullett. In her ground-breaking monograph on the letters of Theophylact of Ochrid, Byzantine metropolitan archbishop of Ochrid, Mullett utilised network theory to analyse the connections of the metropolitan, including addressees, frequency of communication, topics, circles of intimacy, and the uses of his network by Theophylaktos, archbishop of Ochrid. ${ }^{36}$

\footnotetext{
32 StoWers, Stanley K.: Letter Writing in Greco-Roman Antiquity. Philadelphia, Westminster Press, 1986, pp. 1726.

${ }^{33}$ See Hunger, Herbert: Reich Der Neuen Mitte. Der christlichen Geist der byzantinischen Kultur. Wien, Köln, Verlag Styria, 1965, pp. 340-344; HUNGER, Herbert: Johannes Chortasmenos (ca. 1370 - ca. 1436/1437). Briefe, Gedichte und kleine Schriften. Einleitung, Regesten, Prosopographie, Text. WBS 7, Wien, 1969. Henceforth HUNGER 1969; HUNGER, Herbert: Die hochsprachliche profane Literatur der Byzantiner. Byzantinisches Handbuch: Handbuch der Altertumswissenschaft, 12.5. 2 Bde. München 1978, 2. Bde, pp. 208-212.

34 LITTLEWOOD, Anthony: A Statistical Survey of the Incidence of Repeated Quotations in Selected Byzantine Letter-writers. In DUFFY, John - PERADOTTO, John (Eds.): Gonimos. Neoplatonic and Byzantine Studies Presented to Leendert G. Westerink at 75. Buffalo, New York, Arethousa, 1988, pp. 137-154.

${ }^{35}$ LITTLEWOOD, Anthony: An 'Ikon of the Soul': the Byzantine Letter. In Visible Language 10 (1976), pp. 197-226.

${ }^{36}$ MULLETT, Margaret: Theophylact of Ochrid. Reading the Letters of a Byzantine Archbishop. Aldershot, Ashgate Variorum, 1997
} 
Mullett, besides continuing her research on epistolary networks in the Byzantine world, ${ }^{37}$ also issued other questions of Byzantine epistolography, including the role of the classical tradition by the epistolographers, ${ }^{38}$ the performative function of their literary production, ${ }^{39}$ and the role of literary patronage in epistolography. ${ }^{40}$ Her literary research can be paralleled with the respective work done by Littlewood.

Arriving to the question of what a letter according to this work is, first of all, I share the view that a precise definition proves to be evasive, unlike a general specification of the genre. As Michael Trapp states:

A letter is a written message from one person (or set of people) to another, requiring to be set down in a tangible medium, which itself is to be physically conveyed from sender(s) to recipient(s). Formally, it is a piece of writing that is overtly addressed from sender(s) to recipient(s), by the use at beginning and end of one of a limited set of conventional formulae of salutation (or some allusive variation on them) which specify both parties to the transaction. ${ }^{41}$

As all of the letters selected for this study square with these features, and this definition suffices the demands of my analysis, I am going to use it for the purposes of this work.

After forming a working definition of the letter, certain $21^{\text {st }}$-century developments in Byzantine epistolography must be mentioned. Michael Grünbart, the leading specialist of the field in recent decades, has assembled the available editions of all the major Byzantine letter collections, ${ }^{42}$ greatly alleviating the work of future scholars. He furthered the traditional linguistic research via analysing the forms of address in extant Byzantine letters, ${ }^{43}$ and

\footnotetext{
${ }^{37}$ MULLETT, Margaret: The Detection of Relationship in Middle Byzantine Literary Texts: The Case of Letters and Letter-Networks. In OdoRICo, Paolo (Ed.): Épistolographie et la Poésie Épigrammatique. Actes de la 16e Table ronde du XX Congrès international des Études Byzantines, Paris 2001. Paris, Centre d’Études Byzantines, Néohelléniques et Sud-est Européennes, École des Hautes Études en Sciences Sociales, 2003, pp. 63-74; MULLETT, Margaret: Friendship in Byzantium: Genre, Topos and Network. In HASELDINE, Julian (Ed.): Friendship in Medieval Europe. Phoenix Mill, Sutton Publishing Limited, 1999, pp. 166-184.

${ }^{38}$ MULLETT 1981, pp. 75-93.

${ }^{39}$ MuLLETT, Margaret: Rhetoric, Theory and the Imperative of Performance: Byzantium and Now. In JEFFREYS, Elisabeth (Ed.): Rhetoric in Byzantium. Papers from the Thirty-fifth Spring Symposium of Byzantine Studies, Exeter College (University of Oxford, March 2001). Aldershot, Ashgate, 2003, pp. 151-170.

40 MULLETT, Margaret: Aristocracy and Patronage in the Literary Circles of Comnenian Constantinople. In Angold, M. (Ed.): The Byzantine Aristocracy IX to XIII Centuries. Papers of the Sixteenth Spring Symposium of Byzantine Studies (Edinburg, March 1982). Oxford, BAR, 1984, pp. 173-201.

${ }^{41}$ TRAPP, Michael (Ed.): Greek and Latin Letters. An Anthology with Translation. Cambridge University Press, 2003. p. 1.

${ }^{42}$ GRÜNBART 2001A

${ }^{43}$ GRÜNBART, Michael: Formen der Anrede im byzantinischen Brief vom 6. bis zum 12. Jahrhundert. Wien, Verlag der Österreichischen Akademie der Wissenschaften, 2005. Henceforth GRÜNBART 2005
} 
oriented scholarly attention to the representational function and rhetoric background of the genre. $^{44}$

Alexander Riehle, on the other hand, continuing the work of Grünbart, analysed the letter corpus of Nikephoros Choumnos focusing on the representative function of the letters and their 'ritualised communication'. He also examined the function of Byzantine letter corpora as 'official autobiographies' of their authors and certain personal networks of Byzantine authors that could be reconstructed through their epistles. ${ }^{45}$

44 See, for instance, GRÜNBART, Michael: Aspekte der Waren- und Informationsaustauschs in personalen Netzwerken. Byzantion 80 (2010), pp. 157-172. Henceforth GrüNBART 2010A; GrünBART, Michael: Beobachtungen zur byzantinischen Briefrhetorik. In GRÜNBART, Michael - HÖRANDNER Wolfram (Ed.): Épistolographie et la Poésie Épigrammatique. Actes de la 16e Table ronde du XX Congrès international des Études byzantines, Paris 2001. Paris, Centre d'études byzantines, néo-helléniques et sud-est européennes, École des Hautes Études en Sciences Sociales, 2003, pp. 31-41; GRÜNBART, Michael: Der byzantinische Brief und der Raum. In Virtuelle Räume. Raumwahrnehmung und Raumvorstellung im Mittelalter. Akten des 10. Symposiums des Mediävistenverbandes, Krems, 24-26. März, 2003. Berlin, Akademie Verlag, 2005, pp. 343355; GrünBART, Michael: Byzantinisches Rednerideal? Anmerkungen zu einem kaum beachteten Aspekt mittelgriechischer Beredsamkeit. In KofleR, W. - KorenJAK, M. - TILG, S. - TöCHTERLE, K. (Hrsg.): Pontes III: Die antike Rhetorik in der europäischen Geistgeschichte. (Comparanda. Literaturwissenschaftliche Studien zu Antike und Moderne). Innsbruck, 2005, pp. 103-114; GRÜNBART, Michael: Ferngespräche - Zum Briefschreiben im ausgehenden zehnten Jahrhundert. Byzantina 22 (2001), pp. 25-46; GRÜNBART, Michael: Zusammenstellen vs zusammenstehlen. Zum Traditionsverständnis in der byzantinischen Kultur. RHOBY Andreas - SCHIFFER, Elisabeth (Hg.), Imitatio - Aemulatio - Variatio Akten des internationalen wissenschaftlichen Symposiums zur byzantinischen Sprache und Literatur (Wien, 22.-25. Oktober 2008) (Veröffentlichungen zur Byzanzforschung 21). Wien 2010, pp. 129-136.

45 RIEHLE, Alexander: Funktionen der byzantinischen Epistolographie. Studien zu den Briefen und Briefsammlungen des Nikephoros Choumnos (ca. 1260-1327). Inaugural-Dissertation zur Erlangung des Doktorgrades der Philosophie an der Ludwig-Maximilians-Universität München, 2014; RIEHLE, Alexander: Epistolography as Autobiography. Remarks on the Letter-Collections of Nikephoros Choumnos. Parekbolai 2 (2012), pp. 1-22; RIEHLE, Alexander: Kreta: ein 'melting pot' der Frühen Neuzeit? Bemerkungen zum Briefnetzwerk Michael Apostoles. In MÄrTL, Claudia - KAISER, Christian - RICKLIN, Thomas (Hrsg.): “Inter graecos latinissimus, inter latinos graecisssimus" Bessarion zwischen den Kulturen. Berlin - Boston, De Gruyter, 2013 pp. 167-186. 


\section{Violent Conflict between the Latins and the Byzantines}

A key topic in Late Byzantine literature is the violent conflict between the Latins and the Byzantines, which is often portrayed as attacks by the 'violent' Latins against the 'peaceful' Byzantines. The problem is commonly addressed in contemporary Byzantine epistolography too, with various cases of conflict mentioned in these works.

\section{II.1. War}

The analysis of the references to Byzantine-Latin military conflicts in Byzantine epistolography from 1204 to 1453 can be accomplished more effectively via defining subcategories within this main category. The most evident category to begin with, as it was a common phenomenon from 1204 for decades, is that of war.

The letter collection of Michael Choniates, elder brother of the historiographer Niketas Choniates and archbishop of Athens at the time of the Fourth Crusade, provides numerous references to armed conflicts between the Byzantines and the Latin conquerors. One of his letters presents the audience with images of Byzantine success and victory over the 'Italians'. The letter was written to Theodoros I Laskaris (1204-1222), founder of the Empire of Nikaia, in 1208. Michael Choniates stated that 'the swallowing army from Italy' attempted to cross into Anatolia from Europe, and brands this Italian army for 'loving strife'. However, Theodoros I fortified the maritime border of Asia Minor with the barrier of his arms and made everything impassable for the Italians. And, just like nothing is passable beyond of the Pillars of Hercules, so is the Bosporus for those vainglorious ones. ${ }^{46}$

Choniates prays for it that not only Asia Minor would be made unobservable for the Italians by Theodoros, but the Queen of Cities would be free from their hybris and would he [Theodoros] drive them away like mad dogs from their [of the Byzantines] holy enclosures around their Jerusalem, like the Jebusites of the old times were by King David. They [the

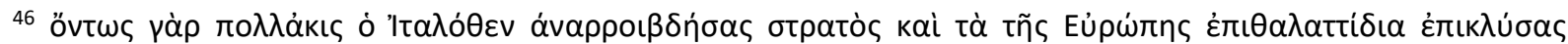

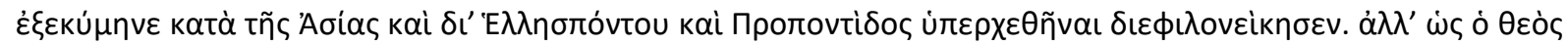

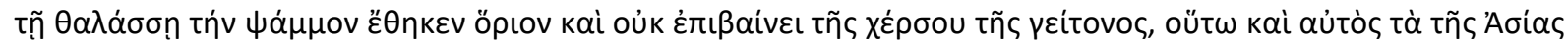

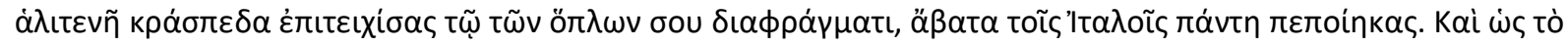

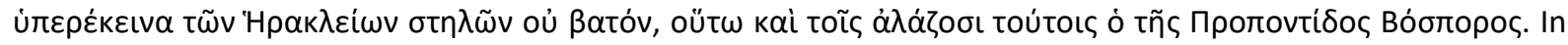
Kolovou, Foteini: Michaelis Choniatae Epistulae. Walter de Gruyter, Berlin - New York, 2001 p. 123-124. Henceforth Kolovou 2001
} 
Byzantines] would make wreaths from blessings, and, to the miserable daughter of Italy, paying back according to the Psalms the payback that was paid back to themselves [to the Byzantines], and [Theodoros] would be called forever a new city-founder, a new synoikistes of the city of Konstantinos, of the imperial one, of the perfectly happy one. ${ }^{47}$

The letter proves to be interesting for more than one reason. The Byzantines are portrayed as the equivalents of the Ancient Israelites, while the Latins are paralleled with the Jebusites, a Canaanite tribe traditionally hostile to the People of Israel, and in control of Jerusalem before King David captured the city. The motive of the mad dog is also very important in this context. In Byzantine culture, the rabid dog is a powerful and common symbol of religious array. Heretics and non-Christians are very often compared to mad dogs, playing upon their perceived irrationality and aggressiveness. ${ }^{48}$ Theodoros I Laskaris appears as a victorious ruler, who is able to drive away the Latins from the holy enclosures of the Jerusalem of the Romans, that is, Constantinople, the City protected by the Virgin Mary, thus becoming a new Konstantinos. ${ }^{49}$

This portrayal is very consistent with the mainstream Byzantine ideological response to the Latin conquest, interpreting the cataclysm as a trial by God for the Romans, who experience a situation similar to the Old Testament trials of the Jewish people, among which the most commonly invoked one is the Babylonian Captivity of the $6^{\text {th }}$ century BC, also promising the eventual victory over the enemy. ${ }^{50}$ The ideological panel of re-establishing the Empire as a new Konstantinos was also well-entrenched in the period of the Latin Empire,

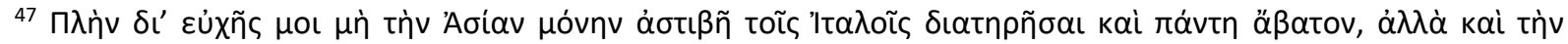

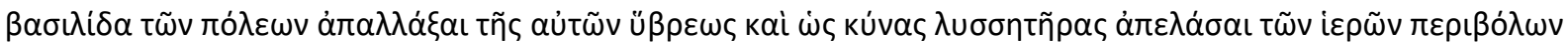

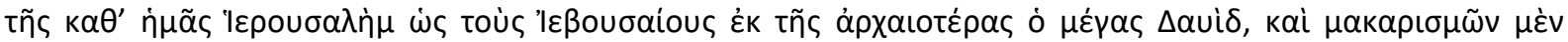

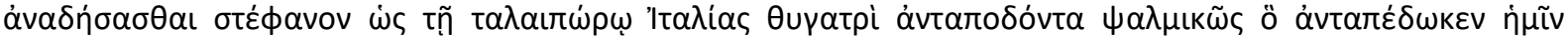

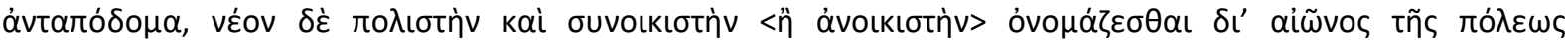

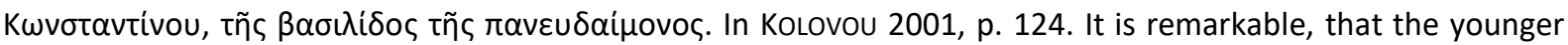
brother of the archbishop, the historian and politician Niketas Choniates also used the phrase 'mad dogs' in an extant speech addressed to Theodoros the I Laskaris. In FRYDE, Edmund: The Early Palaeologan Renaissance. (1261 - c. 1360). Brill, Leiden - Boston - Köln, 2000, p. 79.

48 SCHMIDT, Tristan: Noble Hounds for Aristocrats, Stray Dogs for Heretics. In SCHMIDT, Tristan - PAHLITZSCH, Johannes: Impious Dogs, Haughty Foxes and Exquisite Fish: Evaluative Perception and Interpretation of Animals in Ancient and Medieval Mediterranean Thought. Berlin - Boston, De Gruyter, 2019, pp. 105-133, pp. 119-121.

49 The identification of Constantinople with a new, Roman and Christian Jerusalem, protected by the Virgin Mary, was a well-entrenched element of Byzantine political ideology from Late Antiquity. In AHRWEILER, Hélène. L'idéologie politique de l'empire byzantin. Paris: Presses universitaires de France, 1975, p. 13. Henceforth AHRWEILER 1975

50 ANGOLD, Michael: Byzantine 'Nationalism' and the Nicean Empire. In BMGS 1975 pp. 49-70, pp. 53-55. Henceforth ANGOLD 1975; ANGELOV, Dimiter: Byzantine Ideological Reactions to the Latin Conquest of Constantinople. In LAIOU, Angeliki: Urbs Capta. The Fourth Crusade and its Consequences. La IVe Croisade et ses conséquences. Réalités Byzantines 10. Paris, Lethielleux, 2005, pp. 293-310, p. 297.
} 
underlined very strongly by the propaganda of Michael VIII Palaiologos (1259-1282), the eventual re-conqueror of Constantinople. ${ }^{51}$

The image of Theodoros I Laskaris preventing the Latins from crossing the Bosphoros raises questions too. The Nikaian Empire lost the Battle of Rhyndakos against the Latin emperor, Henry of Flanders (1205-1216), on 15 October 1211, which resulted in the loss of its entire Marmara Sea coast to the Latin Empire, ratified in the treaty of Nymphaion in 1214. ${ }^{52}$ Henry had already achieved an earlier victory against the Byzantine forces in 1205, at the Battle of Adramytteion, but as the Latin Empire had to focus on the Bulgarians, by 1211 only the fortified town of Pegai in Mysia was in Latin hands, a situation that changed dramatically after the Battle of Rhyndakos. The text of Choniates, neglecting its flattering to Theodoros I Laskaris, can refer to the period between 1205 and 1211, probably closer to the second date. ${ }^{53}$ The use of the name 'Italians' for the Westerners is not surprising, as after 1204 the Western conquerors were mostly designated with this ethnonym by the Byzantines. ${ }^{54}$

Regarding the boundaries between the Byzantines and the 'Italians', the first one is constituted by their attiudes towards conflict. The Latins are branded as a group which loves strife, attacking the Byzantines for this reason, who appear as the victims of an aggression that lacks any sound reason. It also suggests that they are rather different in this respect, favouring peace to conflict. The Latins are also charged with being vainglorious, boasting without basis, and although the Byzantines are not described in this respect, the omission of the subject lets the audience to suppose that the victimised community is much more modest than its enemies.

Following his train of thoughts, an extraordinarily strong religious difference is alleged by Michael Choniates. The Byzantines are understood as correct in their religious beliefs, while the Latins are condemned as foul heretics, who are comparable to rabid dogs, making Byzantine religious views superior to Latin ones. The archbishop also accuses the Westerners with hybris, which can refer to both arrogance and the insolent behaviour following it. Meanwhile, Byzantine levels of arrogance or insolence are not mentioned. This omission, supported by the previous comments on the vainglory of Latins, leave an opportunity for the

\footnotetext{
51 See MACRIDES, Ruth: From the Komnenoi to the Palaiologoi: Imperial Models in Decline and Exile. In Magdalino, Paul (Ed.): New Constantines. The Rythm of Imperial Renewal in Byzantium 4th-13th Centuries. Ashgate, Aldershot, 1994, pp. 269-282, esp. 276-278.

52 PRINZING, Günter: Der Brief Kaiser Heinrichs von Konstantinopel vom 13. Januar 1212. Byzantion 43 (1973), pp. 395-431, pp. 409-410 (source text: pp. 415-417).

${ }^{53}$ Kolovou dates it to 1208. Kolovou 2001, pp. 105-106.

${ }^{54}$ KALDELLIS, Anthony: Hellenism in Byzantium. The Transformations of Greek Identity and the Reception of the Classical Tradition. Cambridge, University Press, 2007
} 
audience to regard Byzantines as humble and modest, occupying the higher ground in this aspect too.

The mention of the miserable daughter of Italy ( $\tau \tilde{n} \tau \alpha \lambda \alpha \imath \pi \omega \rho \omega$ 'I $\left.\tau \alpha \lambda i i_{\varsigma} \theta 0 \gamma \alpha \tau \rho i\right)$ proves to be a quite inaccurate claim, as it is not clear who or what the daughter of Italy is, and what the author means by being miserable. The daughter of Italy might be interpreted as the Latin Empire, because of the above-mentioned Byzantine equation of the ethnonyms Italian and Latin after 1204, and a possible misunderstanding of the Latin Empire as the progeny, that is, daughter of the Western world. Relying on this interpretation, 'miserable' seems to be a general devaluation of the Westerners inhabiting and upholding the Latin Empire, mirroring a strong disdain for them.

The allusions to payback and the wish for the inhibition of the Italians observing Asia Minor, on the other hand, obviously point to a strong desire of military retribution, logically for their conquests in the Byzantine world. Considering these 'objectives', the signs of positive bias for the Byzantines mentioned earlier and the previously discussed expression together, the Byzantines should be understood as far from being miserable.

On the contrary, based on their aforementioned exploits, they are supposedly an ethnic community of generally positive characteristics, which image is made even more flattering by the comparison with the 'lowly' Latins. Furthermore, these military actions are suggested to be possible, which supposes Nikaian military prowess being at least on par with that of the Latin Empire, or even surpassing it. In the first case, military prowess does not mean a strong boundary between the two groups, while in the second one, it does, granting the upper hand for the Byzantines even in this field.

Another important contemporary Byzantine epistolographer, George Bardanes, archbishop of Kerkyra and former close associate of Michael Choniates, formed a less religious and more historical metaphor about the Italians in his letter to patriarch Germanos II, written in 122627. Talking about the capture of Dyrrachion by the forces of the Epirote ruler, Theodoros I Komnenos Doukas (1215-1230), Bardanes presents the reader with a parallel of three levels.

First, Theodoros is presented as the equivalent of his distant ancestor, Alexios I Komnenos (1081-1118). Second, the 'Italians' facing the army of Theodoros are paralleled with the 'Italians' fighting Alexios I, that is, the invading Sicilian Norman army. The third level of the parallel is the equation of the two historical situations. The victory over the garrison of Dyrrachion is presented as standing at the same level as the repulsion of the 
Norman invasions, attempting to magnify the importance of the military success achieved by Theodoros. ${ }^{55}$

A few sentences later, Bardanes claims that Theodoros I Komnenos Doukas wants to protect the city from the "beasts grinning from Sicily" that all embarked onto the Adria and would throw stakes at it. Here Bardanes heavily relies on the image of the animalistic and aggressive barbarian, using it to stress the threat meant by the Latins to the Romans and to present Theodoros as a Roman leader capable of protecting his people, who does not deserve the enmity of Germanos II. ${ }^{56}$

There is a certain degree of historical reality behind this exaggerated description of the fight for Dyrrachion. In 1217, the newly elected Latin Emperor, Peter de Courtenay (12171219?) unleashed an attack against the Adriatic city as a retaliation for the offensives of Theodoros I against the Kingdom of Thessalonike. It was hoped that with the campaign they would take control of the important harbour and ease the Epirote pressure on the kingdom that was losing ground steadily in Thessaly and Macedonia. The endeavour, however, proved to be a catastrophe for Peter de Courtenay: Theodoros I ambushed his forces in the area of Dyrrachion, crushingly defeated them and even the body of the Latin emperor was impossible to be found, leaving his survival a possibility for years. ${ }^{57}$

The apologetic tone of the letter regarding the person and actions of Theodoros I, on the other hand, is inseparable from the contemporary ecclesiastical conflict between Epirus and Nikaia, in which his politics played a crucial role. In 1224, after he captured the city of Thessalonike, Theodoros I proclaimed himself emperor, and, after the metropolitan archbishop of the Thessalonike, Mesopotamites refused to oint and coronate him emperor, the ceremony was performed by the archbishop of Ochrid, Demetrius Chomatenos. These actions contradicted the canon law and were considered illegitimate by Germanos II and the Nikaian high clergy, just like the Nikaian emperor John III Vatatzes (1222-1254). ${ }^{58}$

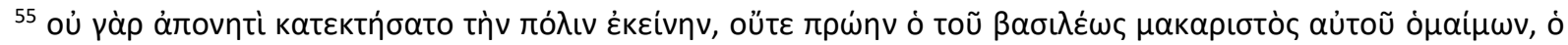

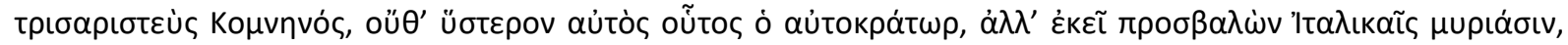

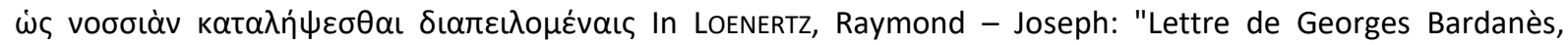

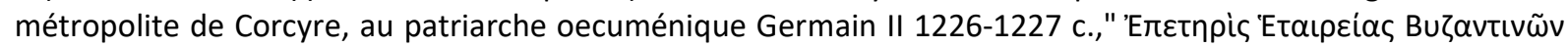

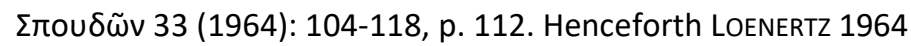

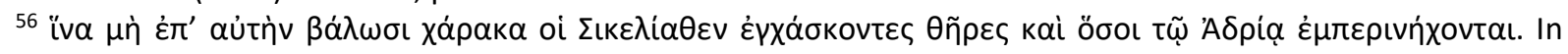
LOENERTZ 1964, p. 113.

${ }^{57}$ NICOL, Donald M.: The Fourth Crusade and the Greek and Latin Empires 1204-1261 In HusSEY, J. M. (Ed.): The Cambridge Medieval History IV: The Byzantine Empire, part 1: Byzantium and its Neighbours. Cambridge, 1966, pp. 275-330, p. 305.

${ }^{58}$ Karpozelos, Apostolos: The Ecclesiastical Controversy between the Kingdom if Nicea and the Principality of Epiros (1217-1233). Thessalonike, KENTPON BYZANTIN $\Omega N$ EPEYN $\Omega N, 1973$, pp. 72-80. Henceforth KARPOZELOS 1973
} 
Therefore, apologetics was very much necessary to attempt to justify these decisions, especially that Theodoros I appointed the new archbishop of Dyrrachion without consulting the patriarch, creating another gravamen for Nikaia. Through pointing to the successful protection of the city from the Latins by his sovereign, Bardanes attempts to justify that Theodoros has the right to control the affairs of the city, offering a hardly satisfying answer to Germanos II. ${ }^{59}$

The main difference between the Latins and the Byzantines implied in the source seems to present itself between their respective attitudes towards conflict. Bardanes envisages a serious

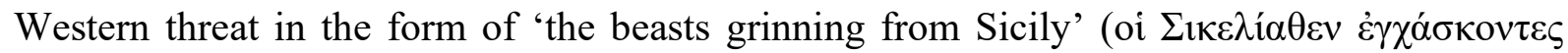
$\theta \tilde{\eta} \rho \varepsilon \varsigma)$, which not only invokes the historical memories of the Byzantine-Norman wars, but also suggests wild, animalistic aggressivity, resulting in a tendency of seeking conflict, while also dehumanizes the Westerners threatening the realm of Theodoros I.

The Byzantines are depicted as the community under the threat of these aggressors, protecting their homeland and themselves. Their attitudes towards aggression are not mentioned, but the stressing of Latin wildness and conflict-seeking and Byzantine Victimhood leaves little doubt that they are to be imagined as relatively peace-loving and restrained, especially compared to their Western enemies.

Epirote propaganda is present, although in a less grandiose way, in another corpus of letters, compiled by Ioannes Apokaukos, metropolitan archbishop of Naupaktos. Writing to the previously mentioned ruler, Theodoros I Komnenos Doukas, Apokaukos praises the addressee for freeing the church of Neopatras from the 'Italian' hand with his strong hand. ${ }^{60}$ Here, hand clearly refers to power, control, invoking the image of a grip and the state of being oppressed.

The title epithet 'strong' ( $\kappa \rho \alpha \tau \alpha$ ló $\varsigma$ ) used for an imperial claimant is also characteristic, as it was one of the common epithets of the Byzantine emperor by his subjects. ${ }^{61}$ At the very same time, Theodoros is presented as the liberator of the Romans that is similarly strong

\footnotetext{
${ }^{59}$ Nicol, Donald: The Despotate of Epirus, Oxford, Basil Blackwell, 1957, p. 96. Henceforth NicOL 1957

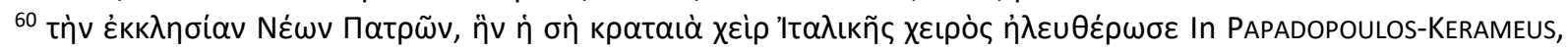
Athanasios: Noctes Petropolitanae. Sankt-Petersburg, 1913 (Reprint 1976), p 263.

${ }^{61}$ GRÜNBART 2005, p. 140.
} 
compared to the previous letter written by Bardanes. The exact date of the conquest of Neopatras by Theodoros I is unknown, but it had to happen around $1218 .^{62}$

An ethnic boundary is not necessarily present in these comments of the author. However, there may be an implicit perception of Byzantine military prowess, which is suggested to be better than that of the Westerners formerly dominating Central Greece, as it might be mirrored by the liberation of Neopatras. However, such an interpretation is far from being sure, as the source mentions only the victory of Theodoros over the Latins, which could have been attributed to several other factors by Apokaukos, including, for instance, superior numbers on the Epirote side, a better strategy, good luck, and divine support.

Furthermore, in his letter to Constantine, who was at that time the surgeon general of the Epirote army, from the years 1218-1219, Apokaukos states that God scourges the 'Italians' with strong hand and sublime arm. ${ }^{63}$ As the letter was written during Epirote advance into the territory of the Kingdom of Thessalonike, taking over Thessaly, ${ }^{64}$ the circumstances fit well for such a portrayal, presenting the Latins as being punished by God, evidently for their sins, which could be easily understood as their sins against the Romans.

But if God scourges the Italians for their sins, and the Byzantines became the tools of this divine punishment, these developments suggest that the Byzantines are a more moral community than the 'Italians'. So, in this very tacit way, the impression of a serious ethnic difference is invoked in the audience.

The reader can also find examples of more concrete mentions of conflict with the Latin oppressors in the corpus of Apokaukos. One of his letters describes a raid conducted by a certain 'Thomas the Italian' against Epirote territories in Central Greece. The letter, addressed to Dokeianos, the contemporary archbishop of Dyrrachion, ${ }^{65}$ states that as Theodoros I possesses the territory of Belechatuïa, ${ }^{66}$ he also possesses 'the Italian Thomas' as a

62 KODER, Johannes: Neai Patrai. In KODER, Johannes - HILD, Friedrich: Tabula Imperii Byzantini Bd. 1. Österreichische Akademie der Wissenschaften Philosophisch-Historische Klasse Denkschriften. Bd. 125. Wien, Österreichische Akademie der Wissenschaften, 1976. pp. 221-222.

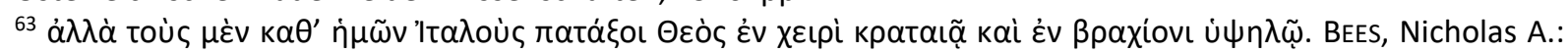
"Unedierte Schriftstücke aus der Kanzlei des Johannes Apokaukos des Metropoliten von Naupaktos (in Aetolien)," Byzantinisch-neugriechische Jahrbücher 21 (1971-1974): 57-160, p. 157. Henceforth BEES 19711974

64 NiCOL 1957, pp. 57-58.

${ }^{65}$ Very little is known about archbishop Dokeianos. What is certain is that he was appointed to his see in 1213 , by a synod held at Arta. KARPOZELos 1973, p. 52.

${ }^{66}$ Belechatuïa was a Byzantine designation of the area of Demetrias and Thebai Phthiotides. Hild, Friedrich: Belechatuïa. In KODER, Johannes - HILD, Friedrich: Tabula Imperii Byzantini Bd. 1. Österreichische Akademie der 
neighbour. ${ }^{67}$ The sentence suggests a dichotomy, in which the rule over the area is to be understood as a positive development, while having Thomas as a neighbour is clearly a negative one.

This suspicion is validated by the following description of the raid organised by the aforementioned Thomas against Epirote territories. Apokaukos states that Thomas is a neighbour for Theodoros and for all, who are descending with a wide laughter to Belechatuïa, just like for the feeding herds around $\mathrm{Bela}^{68}$ and Karouta. ${ }^{69}$ And nobody set against this deprivator [Thomas], but the heart of the lord of these places shivered at his voice and the blood contracted from his extremities. And if the fear of it [of the voice of Thomas] would have not routed all the living, the person in authority at once would not differ from a dead at all.

But as God has not given everyone everything, so he has given to this one [Thomas] playing on the cithara and voice, ${ }^{70}$ for other, his figure is crowned with words, such as for this [for the local lord]. And, if cowardice inhabited his heart, concerning the archbishop and the peasants of the local church, they showed the most courageous thing for a lifetime. And he [the lord] pursued him, just as a furious storm, the undershrubs of herbs and all the rootless ones that are scattered around the earth. To these [the local people] the once pharaoh sent harsh taskmasters, but they do not mix clay with chaff, they do not make bricks and they do not build strong cities for this new and contemporary pharaoh. ${ }^{71}$

How could be these peculiar passages interpreted? First of all, 'the Italian Thomas' is identifiable with Thomas II d'Autremencourt, the lord of Salona, ${ }^{72}$ a vassal of the duke of Athens and Thebes. The father of Thomas II, Thomas I, was killed by Michael I of Epirus in 1210, while Salona was taken by the Epirote forces, and an attempt to take it back was

Wissenschaften Philosophisch-Historische Klasse Denkschriften. Bd. 125. Wien, Österreichische Akademie der Wissenschaften, 1976. p. 133.

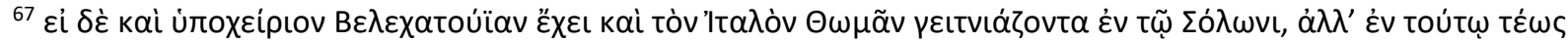

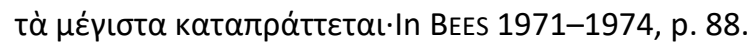

${ }^{68}$ Bela was the see of a suffragan bishop of Neai Patrai, otherwise even the once location of this former settlement is unknown. KODER, Johannes: Bela. In KODER, Johannes - HILD, Friedrich: Tabula Imperii Byzantini Bd. 1. Österreichische Akademie der Wissenschaften Philosophisch-Historische Klasse Denkschriften. Bd. 125. Wien, Österreichische Akademie der Wissenschaften, 1976. p. 132.

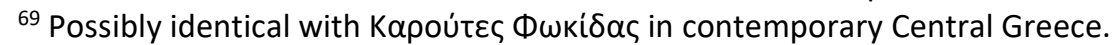

70 II.13.731.

71 IN BeEs 1971-1974, p. 143. Bees convincingly argued that the damaged letter 88 is in fact the missing end of the damaged letter 27 of the corpus, which is accepted in this study. BeEs 1971-1974, pp. 184-185.

${ }^{72}$ Salona is identical with modern day Amphissa in Central Greece. Koder, Johannes: Salona. In KODER, Johannes - Hild, Friedrich: Tabula Imperii Byzantini Bd. 1. Österreichische Akademie der Wissenschaften PhilosophischHistorische Klasse Denkschriften. Bd. 125. Wien, Österreichische Akademie der Wissenschaften, 1976. p. 254. 
thwarted in $1218 .{ }^{73}$ However, by 1223 Thomas II successfully reclaimed his patrimony, as a letter of Pope Honorius III dated to $25^{\text {th }}$ of September 1223 urges the duke of Athens to take part in the fortification of Salona against possible Epirote attacks, offering to absolve his excommunication if he does that, commenting on recent Epirote conquests of territories belonging to the Kingdom of Thessalonike. ${ }^{74}$ It logically dates the letter between 1218 and 1223, while N. A. Bees, based upon these data and other details, dated the letter to 1221$1222 .^{75}$ If Thomas II had just recently recovered Salona, while the Epirote army was advancing in Thessaly and Macedonia, it could be interpreted as a debacle for the reconquista of Theodoros I, and news about any recent defeat of Thomas II against Epiros could serve as valuable material to counter interpretations like that.

Furthermore, remembering to the, from the Byzantine point of view, embarrassing lack of resistance to the Latins in most of the territories conquered by the Crusaders, a representation of the local population routing the Latin lord and his forces could also have its propagandistic value, displaying the moral of Epirote society. As the territories affected by the raid were probably recent acquisitions from the Kingdom of Thessalonike, it may also represent the improvement of Byzantine moral under the rule of Michael I and Theodoros I.

It is interesting that the source concentrates exclusively on Thomas II on the Latin side of the conflict, while presenting the Byzantine lord of Belechatuiia as its main character, besides giving a catalysing role for the bishop and featuring the local Byzantine populace. None of the soldiers participating in the raid led by Thomas II are mentioned, not even as a collective. The very existence of these Latins is only proven by the logical conjecture that a raid must have required troops.

Yet, it can be argued that they are represented by their leader, so the evaluations attached to the person of d'Autremencourt should be interpreted as ones valid to his troops too. The lord of Salona is condemned for being a 'deprivator', which term itself invokes the idea of a weak respect for the property of others, while the local Byzantines are presented as leading a peaceful life, herding among laughs, suggesting a sharp contrast in their norms.

But when the raid reaches the settlement, the roles soon change to the opposite, as the Byzantine populace routs the attacking Westerners. The participation of the Byzantine lord makes the participation of soldiers in the counterattack evident, but it is not mentioned

\footnotetext{
${ }^{73}$ LoCk, Peter. The Franks in the Aegean: 1204-1500. Longman, London and New York, 2014, p. 81. Henceforth LOCK 2014

74 LONGNON, Jean: Les Autremencourt, seigneurs de Salona en Grèce (1204-1311)". Bulletin de la Société historique de Haute-Picardie XV (1937), pp. 15-46, p. 25.

${ }^{75}$ In BEES 1971-1974, p. 185.
} 
explicitly anywhere in the text, unlike the role of the locals, which is stressed by Apokaukos. That gives the impression of a group of soldiers being on the run from Byzantine everymen, suggesting only a slight difference in the quality of training, but a great divide between the morals of the Byzantine and the Latin forces.

The circumstance that the encounter began as a Latin raid with the very probable intent of sacking Belechatuïa enhances the effect, making d'Autremencourt and his forces to appear as a company of cowardly brigands, whose purpose is plundering but who retreat quickly if they face resistance. In contrast, the Byzantines show themselves as brave countryfolk, ready to defend themselves against the aggression.

The origins of letters describing conflicts with the Latins can be traced back not only to Latin-occupied territories and Epiros, but also to the Empire of Nikaia. In a letter addressed to his mentor, Nikephoros Blemmydes, Theodoros II Doukas Laskaris, that time heir to the imperial throne, later emperor of Nikaia (1254-1258), expounds to his teacher that he understands the foreign affairs of the empire are menacing with armed conflicts, suggesting caution and preparedness.

The imperial crown prince states that the hatred moves the multitude and the foreign people against them [that is, the Empire of Nikaia], and, as he asks a rhetorical question, who will aid them? How will the Persian aid the Hellen? The Italian is raging very much too, the Bulgarians can be seen the most plainly, the Serbian is subjugated by force and shrouded: this one [the Serbian] is quickly ours, then quickly not ours, to tell the truth. Only the Hellen himself aids himself, taking his resources from home. ${ }^{76}$

These lines can be seen as characteristic for the ideology of the Empire of Nikaia. The world beyond the borders of the Empire is portrayed as violent and hostile to the state and its people, who, showing a phenomenon typical for contemporary Nikaian elite culture, are proudly designated as 'Hellenes', neglecting the former Byzantine meaning of the word, which was 'pagan'. ${ }^{77}$ The neighbouring people are regarded as unsuitable allies, because of their attitudes towards Nikaia. Persians, that is, Turks, are so unimaginable to become allies of Nikaia that even the idea itself is presented in an ironic question. The Italians, which is an

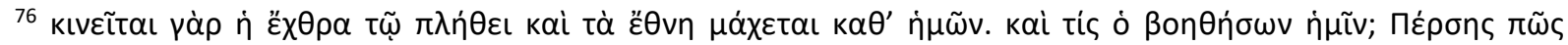

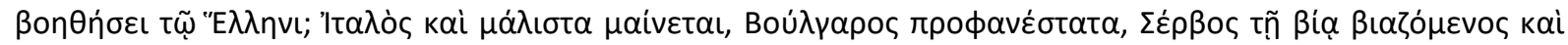

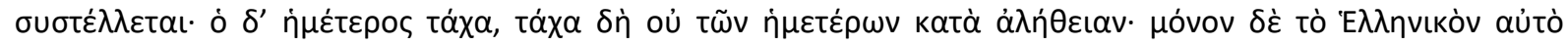

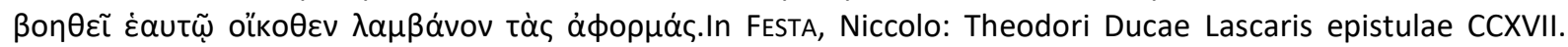
Florence, 1898. p. 58. Henceforth FESTA 1898

${ }^{77}$ ANGOLD 1975, pp. 50-53.
} 
alternative of saying Latins, are depicted as a group raging, in that context, against the Empire, which is most understandable, as the father of Theodoros II, Ioannes III Vatatzes (1222-1254) reduced the Latin Empire to Constantinople itself, and threatened the positions of its surviving vassal states and the ones of Venice too with his expansion.

Bulgaria similarly suffered serious territorial losses as a consequence of the campaign of Vatatzes in $1246,{ }^{78}$ which must have been a relatively fresh gravamen at the time of the writing of the letter, as Theodoros was still crown prince, so he wrote the epistle before 1254, excluding Bulgarians as allies. Furthermore, Serbians are portrayed as a people influenced by force and untrustworthy, who quickly change sides as military fortune shifts. Therefore, the Hellenes have to rely on themselves, utilising their own resources for their military activities, which are motivated by self-defence, as they are shown to be the threatened party in conflicts possibly involving them.

This attitude presented by Theodoros II, i. e. the Greeks standing alone in a sea of hostile nations, was part of a 'traditional-minded' Byzantine reaction to the loss of Constantinople and the territorial reduction of the Empire. The Byzantines were the 'New Israel', who experienced their own 'Babylonian captivity' as Constantinople was in barbarian hands. ${ }^{79}$ The use of the term $\tau \grave{\alpha}$ है $\theta v \eta$ ('the foreign people') also has strong Old Testament connections (goyim), which may have been chosen by Theodoros II because of its relation to his ideological argumentation.

This suspicion is supported by his claim that the Hellenes should rely on their own resources in their struggle against their enemies, which is very consistent with the policies of his father, Ioannes III Vatatzes. ${ }^{80}$ Theodoros II in this part of his letter presents the audience again with a victimisation, or rather an attempt of victimisation, of the Byzantines ('Hellenes') by their enemies, including the Latins. However, the Hellenes are portrayed as being able to defend themselves even in this hostile environment, transmitting a hopeful message to the contemporary Byzantine audience.

Concentrating on possible divisions between the Byzantines and the Latins, there is one that emerges from the lines of Theodoros II. The Byzantines appear at the process of seeking for allies, considering the possibility of cooperating with the 'Italians', that is, Westerners. It suggests openness towards possible military partners, and a notable one, given the history of the relatively recent conflicts with the Latins, which also points to a remarkable willingness to

\footnotetext{
${ }^{78}$ FINE, John Jr.: The Late Medieval Balkans. A Critical Survey from the Late Twelfth Century to the Ottoman Conquest. Ann Arbor, the University of Michigan Press, 1987, p. 156. Henceforth FINE 1987

${ }^{79}$ ANGOLD 1975, pp. 53-55.

${ }^{80}$ ANGOLD 1975, p. 66.
} 
forgive perceived Latin transgressions. It is not their fault that a partnership with the Latins remains beyond reach; Westerners are literally raging against the Byzantines, being so hostile that it excludes the possibility of forming an alliance.

So, it is suggested that the Westerners are consumed by their hatred against the Byzantines, of which the source remains obscure. The audience can fill the gap with several possibilities, including anger for their recent military defeats against the Empire of Nikaia and ideological reasons as prominent ones.

In the Palaiologan Era, which followed the Laskarid period, the Latin Empire had to experience further conflicts between the Byzantines and the Westerners, which are also represented in contemporary Byzantine epistolography. The letter of Patriarch Gregory II of Cyprus (1283-1289), date and place unknown, the latter probably being Constantinople, written to the protosebastos and protobestiarios, describes violent conflicts between Byzantine and Genoese merchants on the Black Sea.

The Patriarch claims that a friend of him, Symeon, a Greek-speaking native of Palestine sought his aid with this problem. The Genoese, who could only enter the Black Sea in earlier times if the emperor let them in, now sail it at their leisure, and not with the earlier conditions. They commit many treacherous deeds against the expedition of the emperor; they display many arrogant and contemptuous deeds. And hence, if the threat of this evil view facing them [the Byzantine sailors] and shaking their souls will not take control of them, [the Genoese] are ready to fight a sea battle against them: their number filled six ships and could have filled more. $^{81}$

The acts described by the patriarch do qualify as open piracy, even by the standards of the age. The Byzantines appear as the victims in a double-folded way: the Genoese attack them, when they peacefully sail on the Black Sea, so they suffer an unprovoked attack. Second, as Gregory states, in earlier times, the Genoese could only enter the Black Sea, if the emperor let them in, but now, they sail on the Pontic waters freely, so they are trespassing in quasi-Byzantine waters, violating the rights of the Empire. It enables them to commit such atrocities, which also demonstrate a decline, an end of a previous, from the Byzantine

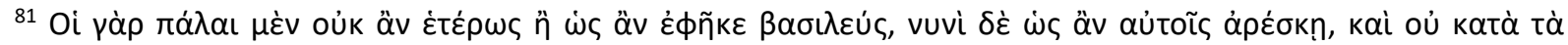

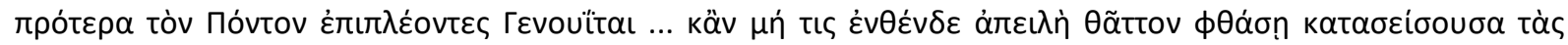

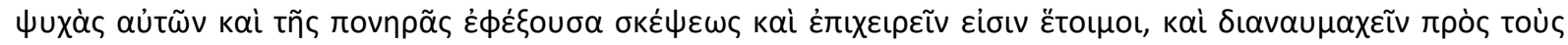

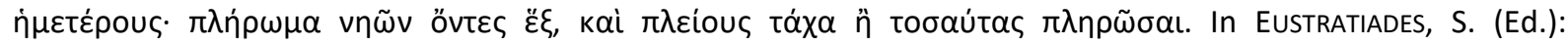

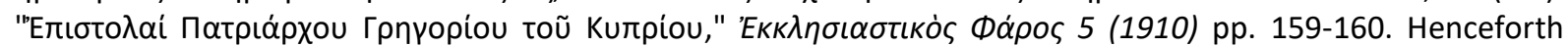
EUstratiades 1910
} 
perspective, more fortunate era. According to Angeliki Laiou, the attack described by the patriarch could not be an isolated incident as the Genoese established their naval control over the Black Sea, making them the dominant trading power in the region of the Pontos Euxeinos. ${ }^{82}$ The outrage over the decline of Byzantine positions is clear in the text, with the evident intent to provoke the urgent intervention of imperial authorities.

The lines of the patriarch also imply differences between the Byzantines and the Genoese, represented by the Byzantine seafarers in the Black Sea and their Genoese equivalents. First, the free sailing of the Genoese in the Pontic waters, the way the Byzantines do, is presented as an unfortunate development, which replaced the earlier state of affairs, when they needed imperial allowance to enter the Black Sea.

According to this portrayal, free Genoese sailing in the area is problematic for two reasons. First, it is a breach of a boundary, which determined clear conditions for their presence in the Black Sea. Second, as free Byzantine sailing in the Black Sea is treated as a natural phenomenon, the fact that the Genoese seafarers reached the same rights as the Byzantines is viewed as unfair. That points to a marked difference between the rights that the Byzantines and the ones that the Genoese 'deserve' according to the author.

Furthermore, the Genoese are charged with arrogance, contempt, and naval attacks targeting Byzantine merchant ships. Not any Byzantines involved are charged with similar behaviours by the source, which conveys the impression that they are not engaged in such deplorable conduct. The unfolding image shows the Byzantine seafarers as moderate, peaceful victims of their Genoese counterparts, who have a seriously twisted understanding of the value of themselves and others and are violent enough to commit piracy.

So, the main boundaries established by this author present themselves on the fields of the evaluation of oneself and others and the attitudes to violence, in both cases granting the higher standing for the Byzantines.

A similar wish for the restoration of Byzantine power, this time seemingly fulfilled, and the happiness felt over it, is expressed in a letter of Maximos Planoudes written to general Alexios Philanthropenos (date and place unknown). Philanthropenos, acting as a commander of the Byzantine contingent which was sent to halt the Turkish expansion in Asia Minor and possibly restore imperial sovereignty over significant Anatolian territories lost under Andronikos II Palaiologos, campaigned successfully against the Turkish forces in the valley

\footnotetext{
82 LAIOU, Angeliki: The Greek Merchant of the Palaeologan Period: A Collective Portrait. The Proceedings of the Academy of Athens, 1982, pp. 96-124, pp. 100-102.
} 
of the river Maiandros between 1293 and 1295. Maximos was a regular correspondent of him and his brother-in-law, Melchisedek Akropolites, until the failed revolt of the general against the emperor in $1295 .^{83}$

Maximos, after lengthily praising the victories achieved by Philanthropenos against the Turks and expressing the pleasure he felt over watching the large number of Turkish prisoners of war taken by the general, mentions that the father of Philanthropenos similarly took prisoners from the ranks of the Gauls, who are presented by Planoudes as a nation ruled by nobody, but only by its own leaders. ${ }^{84}$ This comment refers to a clearly identifiable military action in 1281, in which Michael Tarchaneiotes Palaiologos, the father of Philanthropenos, captured Hugues Le Rousseau de Sully. Le Rousseau de Sully served as the general vicar of Charles I Anjou of Sicily in Dyrrakhion and Kerkyra in 1279-1281, ${ }^{85}$ so his capture was a major Byzantine feat of arms in the conflict of the Kingdom of Sicily and the Byzantine Empire.

Planoudes comments on this victory of Tarchaneiotes Palaiologos stating that the Gauls, that is, the French, do not obey anyone else but the leaders of their own people, suggesting a fiercely independent ethnic community with the military prowess to avoid subjugation, which naturally magnifies the glory of taking a group of them captive. This effect is greatly enhanced as the following triumph of the Byzantines is described as 'bloodless', expressing that the fearsome French warriors did not even resist the father of Philanthropenos and his Byzantine troops.

As the victory of the father against the French is paralleled with the victories of the son against the Turks, a story of Byzantine restoration following a major crisis is presented: the militarily successful years under Michael VIII Palaiologos were followed by unfortunate setbacks under his son, Andronikos II, but, at the time of the letter, these are being reversed by the achievements of Philanthropenos.

Neither of the emperors is mentioned, which gives an opportunity to avoid both the need of sharing the glory between the generals and their autokratores and any suggestion of a

\footnotetext{
${ }^{83}$ LAIOU, Angeliki: Some Observations on Alexios Philanthropenos and Maximos Planoudes. BMGS 4 (1978), pp. 89-99, pp. 89-92.

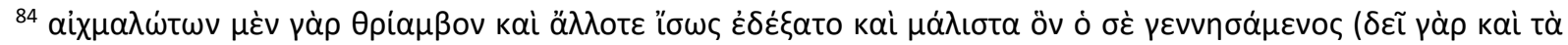

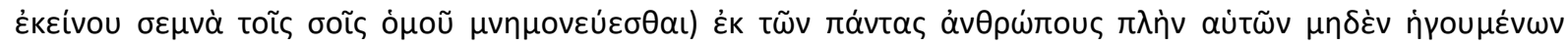

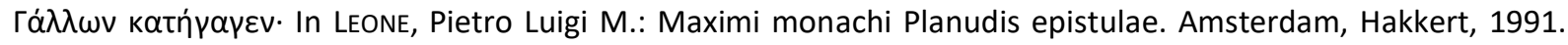
pp. 180-181. Henecforth LEONE 1991

85 PLP 26324, BEYER, Hans-Veit: Die Chronologie der Briefe des Maximos Planudes an Alexios Doukas Philanthropenos und dessen Umgebung. REB 51 (1993), pp. 111-137, p. 132.
} 
comparison between Michael VIII and Andronikos II, which would be possibly unfavourable for the latter one.

It is also worth investigating the relationship between the French and the Byzantines. The latter appear as ruled by nobody else but their own rulers, which, as it has been mentioned above, suggests a high value attached to their independence among them and their ability to protect it. However, the Byzantines could not boast about being ruled by nobody else but their own leaders, as significant 'Roman' populations lived under foreign rule. It could point to an attitude less cherishing towards their autonomy than that of the French or Byzantine military strength representing a lower quality compared to that of the 'Gauls'.

However, Tarchaneiotes and his contingent achieved the surrender of Le Rousseau de Sully and his soldiers, who were 'intruders' in Byzantine territories, without any bloodshed, which gives the impression that the Byzantines are even more protective of their independence and more formidable warriors than the French, beacuse they prevailed to such an extent. The two ethnic communities are compared regarding their appreciation of their independence and their military prowess, and the Byzantines seem to occupy the high ground in both respects.

A few decades later, Nikephoros Gregoras, the famous polyhistor of his age, presents a similar image in his letter addressed to Alexios Doukas Philanthropenos, the governor of the island of Lesbos, to whom Gregoras had wrote more letters between 1328-1336/1337 ${ }^{86}$ The letter was sent from Constantinople in 1336/1337, to Lesbos. Gregoras praises Philanthropenos for his successes as a military commander, including an episode in which he saved Mytilene, the capital of the island, in which he claims that his addressee routed 'the

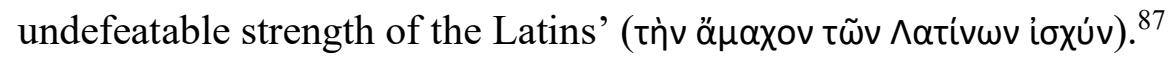

The words of Gregoras here refer to a real, exactly identifiable historical event. Philanthropenos was appointed as governor of Lesbos by emperor Andronikos III (13281341) and his mandate was prolonged before May 1335. After that, he recovered the city of Mytilene that was captured by Genoese forces. In contrast to what the representation of Gregoras suggests, Philanthropenos actually bribed 500 Latin soldiers of the garrison to achieve this remarkable success, as he neutralised the Turkish naval threat in 1336/1337 via a

\footnotetext{
${ }^{86}$ PLP 29752

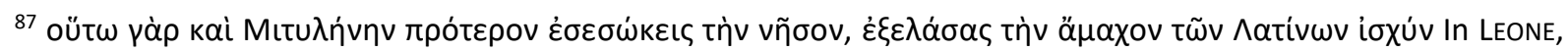
Pietro Luigi M.: Nicephori Gregorae epistulae. I-II. Matino, 1982. p. 281. Henceforth LEONE 1982
} 
handsome sum paid to the Turks for their protection. ${ }^{88}$ So a cunning move that avoided bloodshed is presented by Gregoras as a glorious victory achieved in battle.

This is most understandable regarding the system of social values embraced by Byzantine society. A soldier had to prove his military prowess, first of all, his courage ( $\dot{\alpha} v \delta \rho \varepsilon i ́ \alpha)$, to become a respectable member of his profession in the eyes of fellow Byzantines. ${ }^{89}$ Sabotage and ruse were not alien from Byzantine warfare and even enjoyed a certain respect, ${ }^{90}$ but it offered less opportunity for praising the courage of the subject. The purpose of establishing or maintaining a good relationship with the addressee, especially keeping the representative function of the Byzantine letter in mind, may have influenced Gregoras to present the events in this more flattering way.

Regarding the Latins in question they are depersonified and referred to as a collective, 'the

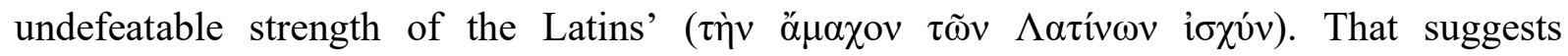
extremely high military strength, stating the impossibility to prevail against it. Yet, Philanthropenos is claimed to have routed ( $\dot{\varepsilon} \xi \varepsilon \lambda \alpha ́ \sigma \alpha \varsigma)$ this powerful force, proving that he and his forces were even more formidable than them. Therefore, with respect to military prowess, Byzantine vantage is established in the text.

In a letter written to Konstantinos Palaiologos, the later emperor Konstantinos XI Palaiologos (1448-1453), Ioannes Dokeianos praises the war waged by Konstantinos against the Latins in the Peloponnesos. According to the letter of Dokeianos, Konstantinos, as soon as he arrived in the Peloponnesos, waged war against the local Latins. And, eagerly plunging himself into this struggle, and neither mistrusting the irregularity of the circumstances, nor the difficulty of the question, he captured ancient Patras, the far-famed city, disposing the onecalled-the-first. He achieved a conspicuous victory, showing the ones fighting without restraint as refugees. ${ }^{91}$

The above description of the events, however poetic and grandiose it is, can be identified with the early Peloponnesos campaigns of Konstantinos. In 1426, Carlo I Tocco (1376-1429)

\footnotetext{
88 PLP 29752

${ }^{89}$ MAgdalino, Paul: Honour among Romaioi: The Framework of Social Values in the World of Digenes Akritas and Kekaumenos. BMGS 13 (1989), pp. 183-218, p. 201.

${ }^{90}$ For this attitude, see ALBU, Emily: Bohemund and the Rooster: Byzantines, Normans, and the Artful Ruse. In GoumA-Peterson, Thalia (Ed.): Anna Komnene and Her Times. New York-London, Garland Publishing, 2000. pp. 159-168.

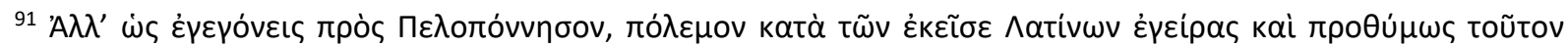

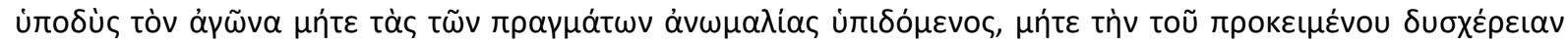
ن்

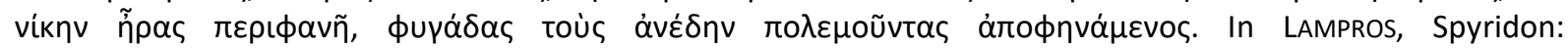

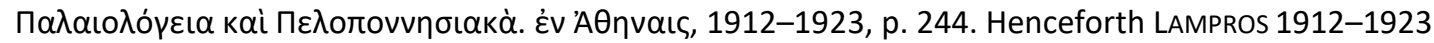


count palatine of Kephalonia, despot of Epiros and ruler of Clarentza and Elis in the Peloponnesos, broke his truce with the Theodoros Palaiologos, the despot of Morea. In 1427, the emperor Ioannes VIII (1425-1448) and Konstantinos moved to the peninsula with an army to aid their brother, Theodoros. In a naval battle near the Echinades-islands, west of the Peloponnesos, the fleet of Carlo I Tocco suffered a crushing defeat, so he sought peace, offering his niece, Maddalena Tocco to Konstantinos as a wife, with his Peloponnese territories as her dowry, which was accepted. Konstantinos, establishing himself in the Morea, turned against the city of Patras, governed by its archbishop, Pandolfo Malatesta, brother-inlaw of Theodoros Palaiologos. In a long and complicated siege in 1429-1430, during which Konstantinos was once almost captured by the defenders, first the city itself was surrendered by its leading citizens to Konstantinos, then the garrison of its citadel capitulated to him. ${ }^{92}$

The campaigns are portrayed by the words of Dokeianos as heroic acts committed by Konstantinos. He begins his stay at the Morea with launching a campaign against the local Westerners, who do not receive any further designation. The young scion of the imperial dynasty, not caring about the difficulties and irregularities of the situation (including the captivity he narrowly escaped, not mentioned by the rhetor), takes Patras.

The city is described as 'ancient' and 'far-famed', using aggrandizing epithets, which enhance the impression that its successful siege was a great victory. From a Byzantine viewpoint, it was peculiar that Patras was ruled by a Catholic archbishop that may be responsible for the strange designation of its sovereign ('the one-called-the-first'), while the surrender and retreat of the garrison of the archbishop is probably behind the reference to the warmongering enemies becoming refugees.

It is worthy of attention that the letter represents the Byzantine side as the active, aggressive agent that initiates the conflict, while the Latins constitute the passive, defensive, reactive side. With that, the text belongs to the minority of the sources analysed in this chapter, as most letters depict Byzantine-Latin conflicts in the exact opposite way, attributing aggressivity and conflict-initiation to the Westerners, and the Byzantines are the peaceful subjects of this aggression, who are forced to respond to it.

In these cases, the Latins do not bear any responsibility for the escalation of the situation as the aggressors, while the deeds of the Byzantines are framed as rightful self-defence against unreasonable violence. There is not any self-representation as victims-of-aggression in that case, but an image of them as triumphant conquerors is promoted. Aggression from the

\footnotetext{
92 NICOL, Donald: The Immortal Emperor: The Life and Legend of Constantine Palaiologos, Last Emperor of the Romans. Cambridge, University Press, 1992, pp. 8-11.
} 
side of the Byzantines does not receive any reasoning, as the campaigns aimed at reconquering former 'Roman lands, inhabited mostly by 'Romans', make them most evidently rightful acts in the eyes of Dokeianos and his targeted potential audience.

The difference between offensive, victorious, powerful Byzantines and defensive, defeated, less powerful Latins is underlined by the claims that the Latins fought with all their strength, yet they had to escape as refugees. If all their efforts proved insufficient to thwart the Byzantine conquest, then the Byzantines had to be more formidable then the Latins. The remark that they became refugees can further enhance the gap between their respective levels of power in the mind of the audience, as it implies utter defeat.

A rather interesting comment on the topic of violence can be found in the letter corpus of Ioannes Eugenikos. In one of his letters written to the despot of the Morea, Demetrios Palaiologos in 1453, Eugenikos addresses the despot to exhort him for the Church of Christ. After a segment arguing for the claim that every calamity on this world is nothing against Christ and truth, Eugenikos turns to his deduction. If many and great dangers preceded, it is proper to generously receive everything for their [of the Orthodox believers] piety, and not trusting the human things, respecting more the fear of God, that even those say, loving the truth, who take council in the City bitterly and ill-advisedly. But, for the Franks never to harm them [the Orthodox believers], let there be a colour of Latinism, nor the neighbours, nor the Pope, nor the lord Gregorios [to harm them] ${ }^{93}$

Here the audience meets with a different presentation, than in the cases discussed earlier in this chapter. The most notable is the vagueness of the term 'harm'. It very clearly covers the field of violent atrocities, but it can refer to many other methods of disadvantageously influencing the life of others. It may include, for instance, theft, cheat, dishonest trading policies, including the very actual problem of Catholic people oppressing Orthodox people living under their rule in the period of Eugenikos' rule.

The difference between the levels of power between the Byzantines and the Franks, that is, Latins is apparent, as the former are depicted as having to feign Latinism, with other words, Catholicism, to avoid Western aggression. It would not be the case if the balance of power would not favour the Franks. Moreover, Byzantines once again appear as the suffering party, who have to pretend to adhere to the Latin beliefs to avoid harsh Catholic retaliation.

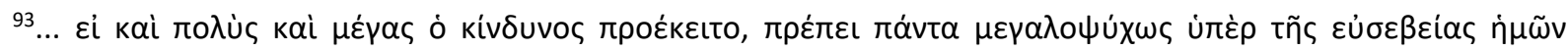

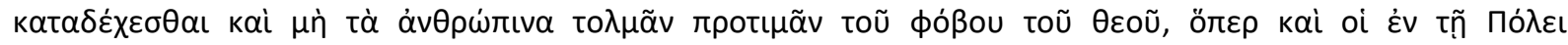

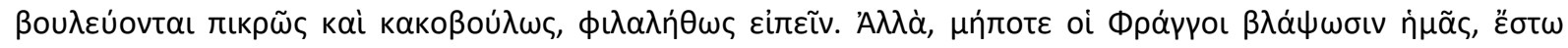

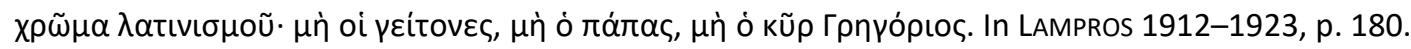


That frames the Franks as prone to act aggressively over denominational differences, while leaving the audience in blissful ignorance about how peaceful the Byzantine behaviour would be in a reversed situation according to Eugenikos, not mentioning his own preferences in such a hypothetical situation. These remarks, although they are concerned with possible Western aggression against Byzantines, also lead to another subject common in the analysed sources, that is, the question of Latin 'tyranny'.

\section{II.2. Oppression}

A recurring motive in the letters of Choniates is 'Italian tyranny', occurring in four different letters. In three cases the expression has other epithets too. In a letter to Euthymios Tornikes, he praises his friend for the achievement of having guided noble young children into the light through the Italian and 'discussion-hating tyranny'. ${ }^{94}$

The use of the term 'discussion-hating' ( $\mu 1 \sigma o \lambda$ ó ${ }^{\circ} \mathrm{v}$ ) for the governemental system in the Duchy of Athens invokes certain entrenched stereotypical images. The Greco-Roman image of the barbarian traditionally included the lack of education, being uncivilised and hostile towards culture, at the very same time affirming perceived Greco-Roman cultural superiority by comparison. ${ }^{95}$

Such an interpretation is supported by the claim that Tornikes educated the local Byzantine youth notwithstanding the rather sorry attitudes of the government, which seems to point well beyond a mere aversion to discussions involving public affairs, which could be another interpretation. Therefore, an intellectual boundary between the Latins and the Byzantines is firmly established, with a definite advantage for the latter side.

However, it is also important that Western rule over the territory is described as tyranny, invoking disturbing images of abuses against its mainly Byzantine subjects. The subjugated majority society of the area is portrayed as the victims of their Western minority rulers, who appear as despotic. Meanwhile, their Byzantines subjects, by their mere victimhood and the lack of any references to similar autocratic tendencies, are implicitly suggested to be better in their attitudes towards governance, allowing the audience to perceive another boundary between the two communities, with the Byzantines occupying the higher ground in this case too.

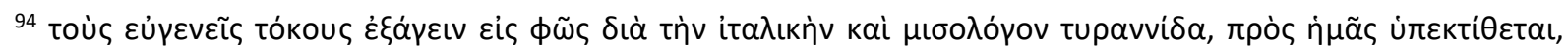

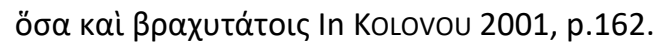

${ }^{95}$ KALDELLIS 2013, pp. 10-11.
} 
In his letter to his nephew, Niketas (not to be confused with the younger brother of the archbishop of the very same name), wondering why his nephew and certain others hold to Athens, he asks if they regard the honey-sweetened juice of the Hymettos mountain as the sweetest lotus? Then, he states that even that juice has turned to the opposite because of the 'rather bitter Italian tyranny'. Choniates closes his train of thought with another rhetorical question, asking what the one [tyranny] of Peisistratos, the one of the Thirties, or the one of the Macedonians is in comparison to that [the tyranny of the Latins] ${ }^{96}$

These words, of course, should not be understood as an advocation for democracy from the side of Choniates. Byzantine political ideology was highly critical towards democracy, regarding it as a flawed system, prone to cause mob rule and social upheaval. ${ }^{97}$ However, Byzantine political thinking made a clear distinction between benevolent monarchy and tyranny, praising the former as the optimal form of governance and shunning the latter as an abuse of power. In that, it relied on the ideas of Plato and Aristotle, while it also presented a tendency of labelling disliked foreign rulers as tyrants. ${ }^{98}$

Besides, the word 'tyrannos' ( $\tau$ ṕpavvos) had a connotation of power of illegitimate source (for instance, rebellions against the lawful emperor), and also kept its ancient semantics, referring to a ruler like 'anax' (őv $\alpha \xi)$ and 'basileus' ( $\beta \alpha \sigma \iota \lambda \varepsilon v ́ \varsigma)$ but with a special secondary meaning, referring to the harshness of the rule. ${ }^{99}$ Therefore, the comparison of Latin rule over Athens with former, infamous tyrannies that ruled the ancient city in the past most probably serves the aim to brand the governance of Othon de la Roche (1205-1225), duke of Athens and Thebes.

The reference to the mountain of Hymettos, the range separating Athens from the inner parts of Attica, the classical Mesogeia, ${ }^{100}$ similarly signifies the classical erudition of Choniates. In Greek mythology, the Hymettos was proverbially known for its abundant and

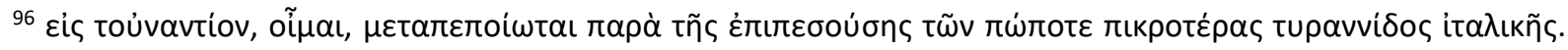
In Kolovou 2001, p. 218.

97 For Byzantine views on democracy, see CAMERON, Alan: Circus Factions: Blues and Greens at Rome and Byzantium. Oxford, 1976, pp. 305-06; Syros, Vasileios: Between Chimera and Charybdis: Byzantine and PostByzantine Views on the Political Organization of the Italian City-States. Journal of Early Modern History 14 (2010), pp. 451-504, p. 456; ANGELov, Dimiter. Imperial Ideology and Political Thought in Byzantium (12041330). Cambridge, UK; New York: Cambridge University Press, 2007, pp. 200-202. Henceforth ANGELOV 2007 ${ }^{98}$ ANGELOV 2007, pp. 245-246.

99 ILIEVA, Aneta: Frankish Morea (1205-1262) Socio-cultural Interaction between the Franks and the Local Population. Historical Publications 9. Athens, S. D. Basilopoulos, 1991, p. 119. Henceforth ILIEVA 1991.

100 KODER, Johannes: Hymettos. In KODER, Johannes - HILD, Friedrich: Tabula Imperii Byzantini Bd. 1. Österreichische Akademie der Wissenschaften Philosophisch-Historische Klasse Denkschriften. Bd. 125. Wien, Österreichische Akademie der Wissenschaften, 1976. p. 174.
} 
excellent quality honey, and that symbolism of the mountain survived until the end of the Byzantine Empire. ${ }^{101}$ Choniates also uses this connotation in his epistle.

The source also suggests differences between the Byzantines and the Latins. Italian rule is condemned as tyranny, suggesting an oppressive government, while the Byzantines are the ones suffering the abuses committed by this system. The nature of this alleged tyranny is not described, just like the attitudes of the local Byzantine population towards autocratic political systems.

The former omission allows the possible audience to freely imagine the presumably abhorrent governance of the Latin elite. But the latter one, combined with the bitterly condemning verdict of archbishop Choniates, a member of the local Byzantine community, gives an impression that the oppressed majority would perform better in case its members governed the territory, exacting a definitely less harsh rule. Comparing the two ethnic groups mentioned in this letter, the Byzantines seem to be more temperate in their attitudes towards power, more modest and less prone to abuses than the Latins.

A rather similar expression appears in another letter of Choniates addressed to Theodoros I Laskaris. Choniates praises the archon thematikos and sebastos Chalkoutzes, coming from Euripos on the island of Euboia and a 'Latin-hater man', but who else would be friendlier towards the Roman state? Still unable to bear the hybris of Latin tyranny, he renounced all his belongings, children, homeland, relatives, and chose to depart and risked living somewhere under the rule of the Roman state, rather than staying in the tyrannised homeland and under the Latin hand. ${ }^{102}$

The letter is a recommendation of the refugee Chalkoutzes to the Emperor. One of its devices is stressing the loyalty of Chalkoutzes towards the Byzantine Empire, but his generalised hatred towards the Latins is also underlined. As the emperor cannot be regarded an unjust or unscrupulous ruler, who prefers persons based upon their utility and not caring about their human qualities, the hatred of Chalkoutzes, this very strong negative emotion, has to be justified for a certain degree and not merely mitigated by his love for the 'Roman' Empire.

An indeed, Choniates describes that Chalkoutzes has left behind all his belongings and his family because of his inability to tolerate the hybris of Latin tyranny anymore and his desire

\footnotetext{
101 RHOвY, Andreas: Reminiszenzen an antike Stätten in der mittel- und spätbyzantinischen Literatur. Eine Untersuchung zur Antikenrezeption in Byzanz. Göttingen, Peust \& Gutschmidt Verlag, 2003, pp. 219-220.

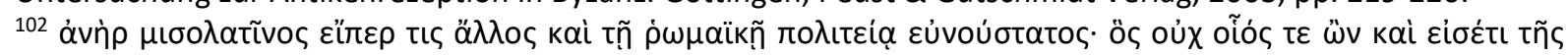

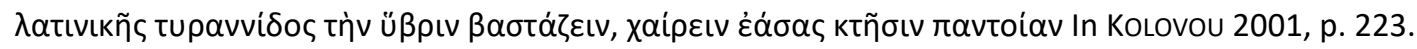


to live under Roman rule. Such sacrifices made by the refugee for these reasons point to a very strong attachment to the Byzantine state on the one hand, but also to a rather harsh Latin autocracy on the other, which was also characterised by extreme arrogance, hybris.

It is suggested that the Empire of Nikaia, under a Byzantine government regarded as legitim, should be free, in strong contrast to the island of Euboia, ruled by Latins who usurped control over it, where tyranny holds sway. Therefore, a strong dichotomy is implied between the Byzantine elite of Nikaia, whose rule is 'free' and legitim, and the Latin elite of Euboia, whose rule is tyrannical and illegitim.

Meanwhile, the Latins of Euboia are also branded by their boundless arrogance. Such a trait is not mentioned regarding the Nikaians, who, already standing in contrast to the Latins with respect to tyranny, are easily supposed to be better than the Westerners in this regard too by the audience.

However, it is not the only version of the story of the refugee archon. In his letter to patriarch Michael Autoreianos of Constantinople (1206-1212), Choniates depicts another negative image of perceived Latin autocracy, through another account of the story of Chalkoutzes. The archbishop laments that on the island of Euboia, the pansebastos Chalkoutzes, whom Choniates calls the best among the archons of Chalkis in Euboia, was subject to the common adversity and 'went under the very heavy yoke of Italian tyranny'. ${ }^{103}$ When he could not bear the tyrannical yoke anymore, he escaped without his belongings to Nikaian territory, and Choniates asks the patriarch to aid the unfortunate aristocrat.

As Kolovou states, both letters were written in the period between 1208 and 1212, just like a third one, that recommends Chalkoutzes to the archbishop of Crete, Nicholas, without mentioning his anti-Latin sentiments or even his very name. ${ }^{104}$ This period correlates with major changes in the history of Euboia. In 1205, the island was conquered without any resistance by Boniface of Montferrat, king of Thessalonike. Boniface donated the island to Jacques d'Avesnes, who in turn parted the island among three Veronese noblemen.

These three major vassals, Ravano della Carcere, Pecorraro and Giberto, ruled the island from the death of d'Avesnes in 1206 to 1209, when Ravano achieved sole control. Under

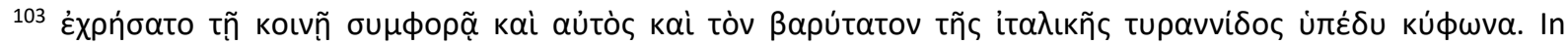
Kolovou 2001, p. 224.

104 See Kolovou 2001, p. 130. The omission of these details from the letter to archbishop Nicholas is probably connected to the fact that the island was under Venetian rule and, if the letter was intercepted, the consequences could have been very serious for both sender and addressee. Besides, the bearer must have been capable of giving these crucial pieces of information.
} 
Ravano, Venetian influence gradually strengthened, and after his death in 1216, the island was parted between the inheritors of the three original triarchs and the Republic of Venice, while the new triarchs accepted the suzerainty of the Serenissima, establishing de facto Venetian rule over Euboia. ${ }^{105}$

These events, resulting in drastic changes in the governance and power-relations of the island, must have been sufficient to convince a Byzantine aristocrat to choose immigration to 'Roman' territory. Choniates also states that it is better to choose the life of a wanderer without fear than being the slave of barbarian brutality at home, ${ }^{106}$ invoking another powerful image of oppression and absence of civilisation.

It is noticeable that Choniates designates Chalkoutzes as a person hailing from Euripos in his letter to Theodoros I Laskaris but identifies him as an archon from Chalkis when writing to patriarch Autoreianos. Here Choniates clearly demonstrates his classical erudition. Euripos and Chalkis are the very same settlement. The name Chalkis was the original name of the town, but, from the $6 / 7^{\text {th }}$ centuries, it fell from use, and after that the town was known as Euripos, and the name Chalkis was used only in a classicising context. ${ }^{107}$

Turning towards the image of the Latins in the second account of the story, it is notable that tyranny is once again pronounced, but this time not the image of hybris, but that of a yoke accompanies the charge. Being a powerful symbol of servitude it greatly stresses this aspect of Latin rule, which could have been the more outrageous regarding the fact that an archon had to suffer such an abusive regime.

As Chalkoutzes escaped from this Latin tyranny to the Empire of Nikaia, the Nikaian system of governance is supposed to be considerably better. It all points to a marked difference between the Latins, who establish tyrannical rule comparable to a yoke, and the Byzantines, who organised a state in Nikaia where such abuses are thought to be absent.

Mentions of 'Italian tyranny' in the letters of Michael Choniates do not end with his versions of the sufferings of Chalkoutzes. In a letter written to Euthymios Tornikes, Choniates complains that he finds it most tragical that Tornikes has some good words about 'Italian

\footnotetext{
105 KODER, Johannes: Negroponte. Untersuchungen zur Topographie und Siedlungsgeschichte der Insel Euboia während der Zeit der Venezianerherrschaft. Wien, Verlag der Österreicischen Akademie der Wissenschaften, 1976, pp. 45-46.

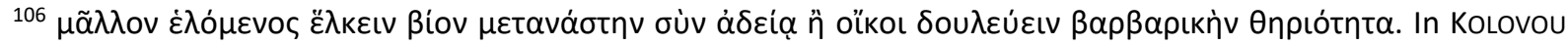
2001, p. 225.

107 KODER, Johannes: Euripos. In KODER, Johannes - HILD, Friedrich: Tabula Imperii Byzantini Bd. 1. Österreichische Akademie der Wissenschaften Philosophisch-Historische Klasse Denkschriften. Bd. 125. Wien, Österreichische Akademie der Wissenschaften, 1976. pp. 156-158, p. 156.
} 
tyranny' in the letters he sends to him. Though there are Hellenic theatres and stages, and there are viewers and listeners indeed, Tornikes could very much wonder the pathetic grandiloquence.

Tornikes himself wondering, Choniates too may wonder whether a tongue so much trained for saying things well could interpret magnificently what small is, and very solemnly that is cheap, then he [Tornikes] has told what great is with so much magnificence and proportionally. ${ }^{108}$ Western rule, designated as Italian, is suggested to be culturally detrimental or at least depriving contemporary Greek theatre from suitable themes with its oppressive atmosphere, leading to mediocre works being performed.

A standard to which Latin rule is compared, has to exist, which is logically to theatrical life of the Byzantine rule, personally experienced by both the author and the addressee. The great skills that contemporary authors can only waste on minor subjects or observe silence, had to be acquired in those decades, suggested to offer more solemn subjects besides erudition.

In this case, Latin and Byzantine governance are not only compared as the former standing for tyranny, while the latter being a 'fair' rule, but Latin despotism is also portrayed as harmful for theatrical life, giving the authors subjects that are mediocre at best, tacitly opposed by Byzantine rule that supposedly offered them sublime topics to write about.

Tyranny also appears in another context. In a letter to George the sebastos, who can be identified as Georgios, archbishop of Kerkyra and the nephew of Choniates, ${ }^{109}$ Michael Choniates exclaims how much they [the Romans] were enriched in bad things. It was not enough to be under the tyranny of foreigners and to be appointed to the rank of slaves, but to so much pain of their wounds, this one add more, who is allegedly a compatriot, whose very person's flame ran over great parts of Hellas and the Peloponnesos before the Italian

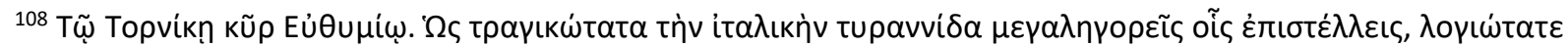

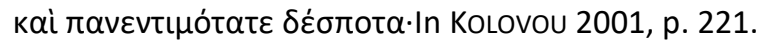

${ }^{109}$ BECK, Hans-Georg: Kirche und theologische Literatur im byzantinischen Reich. 2., unveränd. Aufl. Handbuch der Altertumswissenschaft Abt. 12, Byzantinisches Handbuch, Teil 2, Bd. 1. München: Beck, 1977. p. 702. Henceforth BECK 1977.
} 
onslaught, and the brands burn after the attack. ${ }^{110}$ Later in the same letter, he expounds how the Italians besieged the city of the tyrant of Nauplion. ${ }^{111}$

The tyrant of Nauplion referred to in the letter can be identified with the infamous Byzantine magnate, Leon Sgouros, ${ }^{112}$ de facto ruler of the North Eastern Peloponnesos and later the third son-in-law of the dethroned ex-emperor Alexios III Angelos (1195-1203). Sgouros took hostage and later, while he was already under Latin siege in the Acrocorinth, the citadel of Corinth, murdered the son of Georgios the sebastos, merely for breaking a glass at his table while serving the dishes. ${ }^{113}$ The boy was a relative of Choniates, and it is worth to mention that Choniates himself was threatened by Sgouros in 1204, when the magnate tried to attach Attika to his domains, and the besieged city of Athens was successfully defended against him by the archbishop. ${ }^{114}$

Therefore, Choniates had more than enough personal motivation to display the imminent defeat of Sgouros in the hands of the Latin forces as a rightful judgment over him for his actions. At the very same time, the author is maybe using an ancient topos for the events. Barbarians had been portrayed in Greco-Roman culture as the tools of divine punishment since Classical Antiquity.

Even more remarkable is the claim by Choniates that Sgouros and his rule are partly responsible for the acceptant behaviour that the inhabitants of Attica, Boiotia, and Chalkis show towards the Latin rule, because he was a worse tyrant than the Latins. As he states, the Italians are judged in comparison to him [Sgouros]. By the evils of him, the ones from these [the Italians] are more humane and, the ones from foreign stock seem to be more civilised than the one from the same stock, and, in general, more suitable.

Evidence for that is that nobody from cities, which are serving to the Italians, escaped to him [Sgouros], who is from the same people. Because this [escaping to him] was nothing else but one fleeing from smoke and falling into fire. And from the forts tyrannised by him, those

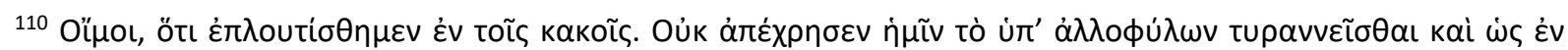

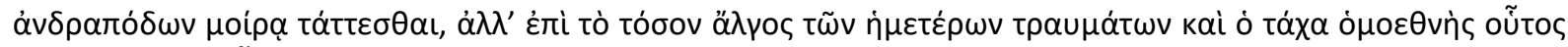

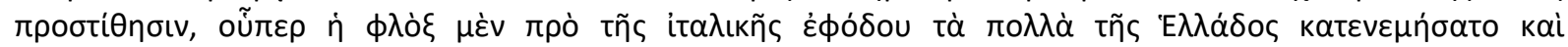

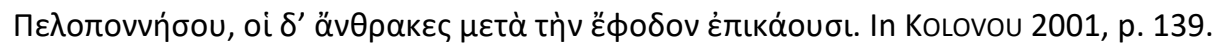

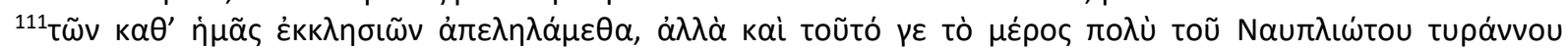

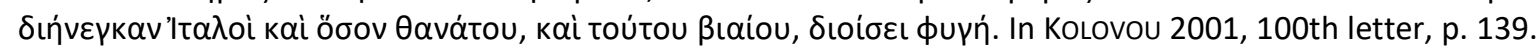

${ }^{112}$ For a summary of the activities of Leon Sgouros, see ILIEVA 1991, pp. 108-134.

113 KALDELLIS, Anthony: The Christian Parthenon. Classicism and Pilgrimage in Byzantine Athens. Cambridge, University Press, 2009, p. 164.

${ }^{114}$ For the conflict between Choniates and Sgouros, see HeRRIN, Judith: Realities of Byzantine Provincial Government: Hellas and Peloponnesos, 1180-1205. Dumbarton Oaks Papers, Vol. 29 (1975), pp. 253-284, pp. 265-266.
} 
who were able to escape happily deserted to these ones [the Italians], as if they had been set free from Hades itself.

As Choniates briefly states it, the clearness of the facts testifies about it, as where are so many of the inhabitants of Argos, Hermione and Aigina? ${ }^{115}$ Where are the happy citizens of Corinth? Do they not go away all, unseen and unheard of? But the Athenians, the Thebans, the Chalcidians and all of those who live beside the sea more upwards, stay at home and have not escaped from their houses yet. ${ }^{116}$

The reasons behind the relative swiftness of the Latin conquest following the Sack of Constantinople in the Aegean is still vehemently debated by historians, most of them seeing it as a result of demoralisation caused by the shock of the fall of the capital. ${ }^{117}$ The Byzantine contemporaries themselves tended to explain it with divine punishment for their own grave sins. ${ }^{118}$

In the case of the letter of Michael Choniates, as he writes about the events in Central Greece and the Peloponnesos, the concept of sin dominates his description, but the main blame is on Leon Sgouros, and implicitly on his loyalists, whose evil deeds made his rule less acceptable for the Byzantine population than the Latin domination. This interpretation provides at least an excuse for the behaviour of common Byzantine citizens.

Besides, the Latins are portrayed as noticeably more civilised and more 'Roman-like' than Sgouros, who is once again branded with the name 'tyrant'. However, these qualities are relative, bearing any meaning only by comparison. The Latins are not civilised and 'Roman' enough to qualify as real Roman archontes, being under their rule is still 'servitude'

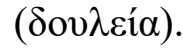

In addition, when he mentions that the inhabitants of territories under Latin rule in Central Greece did not escape their homes, Choniates uses the expression 'and not yet' (ov่ $\delta \varepsilon \dot{\pi} \omega$ ),

\footnotetext{
115 Important settlements in Argolis, the main power base of Sgouros in the early 13th century.

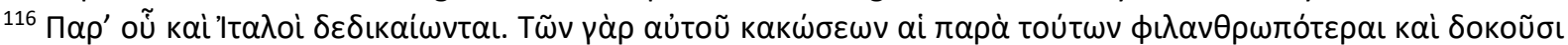

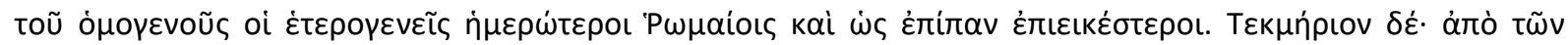

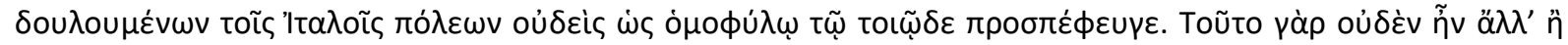

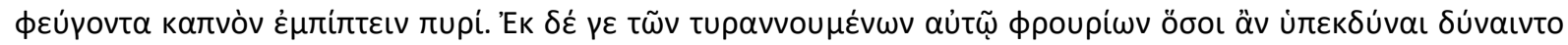

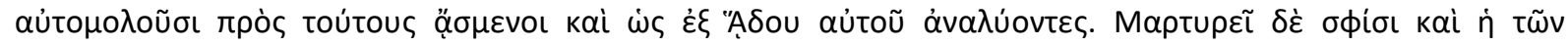

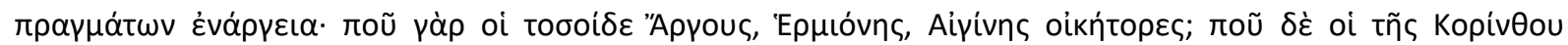

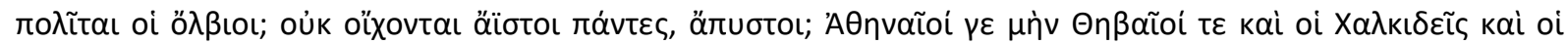

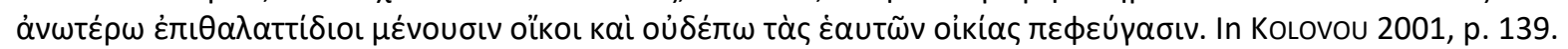

${ }_{117}$ ANGOLD, Michael: Greeks and Latins After 1204: The Perspective of Exile. In ARBEL, Benjamin - HAMILTON, Bernard - JACOBY, David (Eds.): Latins and Greeks in the Eastern Mediterranean After 1204. London, Frank Cass, 1989, pp. 63-86, p. 66-67.

118 MACRIDES, Ruth. '1204: The Greek Sources'. In Laiou, Angeliki (Ed.): Urbs Capta. The Fourth Crusade and its Consequences. La IVe Croisade et ses conséquences. Réalités Byzantines 10. Paris, Lethielleux, 2005, pp. 141150, p. 146.
} 
leaving open the opportunity of Latin rule convincing them to do so. The norms serving as the base of the comparison between the Byzantines and the Latins are still defined by traditional Byzantine norms. The Byzantines are still supposed to be capable of living up to these high standards, while Sgouros and his accomplices represent a morally depraved minority in the population. Similarly, the complacency of so many Byzantine subjects is explained with their apathy and despair after the experiences of life under the rule of Sgouros, which do not prevent later positive change.

Notwithstanding the aforementioned aspects, Latin autocracy is not only explicitly present in the corpus of Michael Choniates. In his letter written to his nephew, Niketas, referred to above, he ends his epistle with a question relevant to this inquiry. As a closure, he asks his nephew that if they [Michael and his nephew] would not be filled with the ill changes inflicted by Italian hands on the affairs of Niketas, what would the preservation from these things by a myriad of expeditions and supplications use to them [Choniates and his nephew]? ${ }^{119}$

Although the details are far from entirely clear, the words of the archbishop from his selfinflicted banishment to the island of Keos suggest that the affairs of Niketas were suffering from detrimental changes, caused by the Latins ruling Athens. Implicitly, it suggests an abuse of power by the Westerners dominating Attica. The nature of these adverse vdevelopments was most probably well-known to the recipient, making concretisation unnecessary.

If ill changes happened, a previous, more advantageous situation had to exist, which deteriorated as a result of these adverse developments. Regarding the context of the epistolographic corpus of the archbishop, the origins of this 'better' past are to be found in the last decades of Byzantine rule over the peninsula. Therefore, a particular boundary is supposed between Western and Byzantine governance, as the former inflicts negative effects on the affairs of citizens, while the latter offers opportunities for improvement, presumably in connection with its perceived non-oppressive nature.

Implicit statements of Latin oppression are not limited to this case. In another letter, written to Basileios Kamateros, the maternal uncle of the wife of Theodoros I Laskaris, Choniates talks about his own banishment to the island of Keos. The archbishop expounds to Kamateros that he considers his escape from Athens a divine sentence, calling his island a

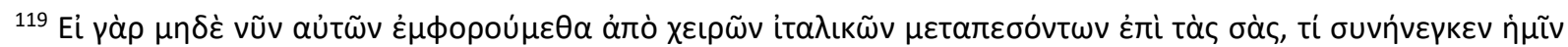

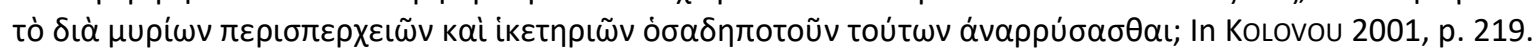


refuge, and stating that it is the third year he spends on it, which place is lamentable, as Kamateros could say. But he [Choniates] does not tell anything trivial, avoiding that the untrodden refuge become easily passable for the "most hateful Italians". ${ }^{120}$

As Choniates stresses that he was forced to leave Athens and is openly afraid of the possibility that Westerners may access his island sanctuary, which was in those years under firm Latin control, a vivid ambience of oppression and fear is conveyed to the reader. The concept of the divine sentence is used to politely reject the offer of Kamateros, who asked Choniates to move to Nikaia. ${ }^{121}$ The adjective 'most hateful' also stresses the representation of the Italians as enemies.

Such a presentation underlines that Latins establish an oppressive rule in the territories conquered by them, in strong contrast to Byzantine-ruled Nikaia, which appears as a land where Michael Choniates could enjoy freedom and peace. The difference is so marked that the only reason why the archbishop does not leave Latin territories for Nikaia is that he thinks that his circumstances are in accordance with the will of God, unquestionable and to be accepted.

Among contemporary Byzantine epistolographers, it is not only Choniates who writes about the subject of Latin oppression. One of his correspondents and friends, Euthymios Tornikes comments on the flight of Choniates from the Westerners. Tornikes draws a parallel between his friend with Moses. The Old Testament prophet fled from the face of the Pharaoh, just like Choniates fled from the Italians, who knew the teachings of the Lord. After that, Tornikes combines the images of Moses opening the Red Sea with his staff and his prayer ${ }^{122}$ and Choniates crossing to the island of Keos, strengthening the parallel further. ${ }^{123}$

However, the parallel between the figures of Moses and Choniates is not the only one, as the 'Italians', evidently the Latins of Athens, are paralleled to the biblical Pharaoh of Egypt. This latter association is far from flattering, regarding the connotations of the Pharaoh in Christian theology, and within that in Byzantine religious thinking.

It is worth mentioning that the Byzantine symbolism of Moses and the crossing of the Red Sea, besides the Exodus, was heavily influenced by the New Testament Letter to the Jews

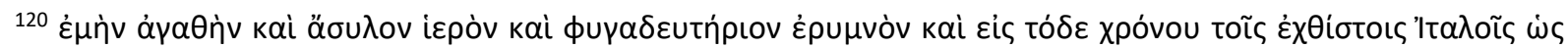

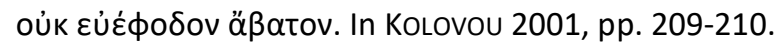

${ }^{121}$ Kolovou 2001, pp. 125-126.

122 Ex, 14:15-30.

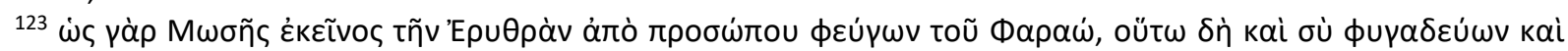

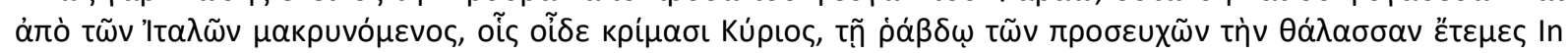
Kolovou, Foteini: Euthymios Tornikes als Briefschreiber. JÖB 45 (1995) pp. 53-74, pp. 71-72.
} 
(caput 7) and The Life of Moses by Gregorios Nyssenos. Notwithstanding these, the most powerful association was the equation of the crossing of the Red Sea and the Battle of the Milvian Bridge between Konstantinos I and Maxentius in 313, regularly used for imperial triumphs since the $10^{\text {th }}$ century. Both events had a special connotation with salvation and fortunate escape from despairing situations too. ${ }^{124}$ It opens a possibility that Tornikes wanted to induce hope into his friend via using this image.

The very circumstance that a man above suspicion of any wrongdoing, the metropolitan archbishop of Athens, fled from the 'Italians', the local authorities, provides a rather dissonant impression, as innocent men should not be on the run. The comparisons of Michael Choniates with Moses and the Italians with the Pharaoh of the Exodus, serve as an explanation of how the audience should judge the situation, making it clear that Choniates should be understood as an innocent victim of persecution, and the Italians as its perpetrators.

The wider implications also involve the nature of Latin rule. Such mistreatment of the archbishop by the Latin authorities suggests that their regime is rather oppressive. And it is very easy to find a counterpole in the form of the earlier Byzantine rule over Attica, during which Michael Choniates did not have to leave his see and flock behind, implying a strong boundary between the two regimes.

The metropolitan archbishop of Naupaktos, Ioannes Apokaukos also discussed the problem of perceived Western tyranny in his epistles. In one of them, written to the Epirote ruler, Theodoros I Komnenos Doukas (1215-1230), at the end of 1224, who is represented as the awaited liberator of the Romans and triumphant over the Latins, Apokaukos voices his hopes that Theodoros, whom he calls 'emperor', may end the 'Italian tyranny' that scourges the Romans, banishing the 'Italian cloud' like the Sun. ${ }^{125}$

Tyranny receives the epithet 'Italian' once again, just like in the letters of Choniates discussed earlier. The image of the 'Italian cloud' suggests threat and even impending catastrophe, underlying the idea that Roman statehood and society are gravely endangered by Westerners. Not only is the imperial title used for Theodoros I in the letter, but he is also

\footnotetext{
${ }^{124}$ Grabar, André: L'empereur dans l'art byzantin. Paris, Les Belles Lettres, 1936 (reprint London, 1971), pp. 9596, pp. 236-37.

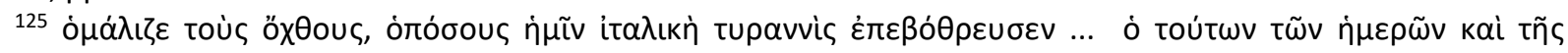

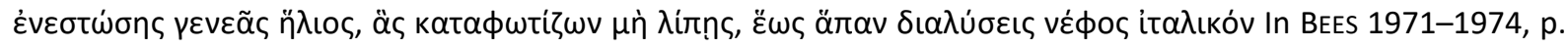
131.
} 
paralleled with one of the main traditional symbols of the Byzantine emperor, the Sun itself. ${ }^{126}$

The difference between Latin and Byzantine rule is quite clearly defined by Apokaukos. The former is branded as tyranny and even associated with a generalised threat to the wellbeing of the Byzantines. The latter, embodied by the victorious Theodoros I, is portrayed as liberation from the other, and the dismantling of Latin rule by him is compared to the Sun vanquishing dark clouds. It all gives the impression of a gaping chasm in the two regimes attitudes towards power and the well-being of those governed, and definitely granting the upper hand to the Byzantine side.

This is not the only occasion when Apokaukos complains about 'Italian tyranny'. In a letter written to the patriarch, that is Germanos II (1222-1240), he recalls how Germanos ceased to communicate with him after becoming a patriarch. Furthermore, he states that it was maybe a consequence of the chasm that Italian tyranny dug for them, which was very deep from both sides. ${ }^{127}$ Besides remembering the patriarch to his less than friendly silence, which is a cliché of Byzantine epistolography, ${ }^{128}$ Apokaukos immediately offers an excuse for his correspondent.

Moreover, 'Italian tyranny' is charged with the digging of deep chasm between the author and the addressee. It is a clear reference to the fact that the Latin Empire separated the State of Epiros and the Empire of Nikaia from each other, hindering communication between the citizens of the two Byzantine successor-states. In addition to this, the contemporary audience could easily think that this hindrance of communication between the two states was connected to the fact that both were treated as possible threats by the Latin Empire, serving as a means to sabotage their possible cooperation against the conquerors.

With this short sentence, Apokaukos also implies that the real conflict is not between Epiros and Nikaia, but between the Latins and these two states, suggesting a common cause for the two successor-states, that is, defeating the Latins, while devaluating their rivalry at the same time.

Through this formulation, the tyranny of the Latins does not remain an abstract vision of an oppressive system, but an 'insight' is offered into its foreign policy, inhibiting communication between states hostile to it, logically to avoid their cooperation against it.

\footnotetext{
126 GRÜNBART 2005, pp. 144-145.

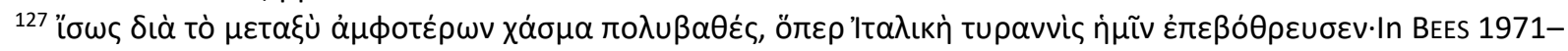
1974, p. 112.

128 MULLETT 1981, p. 79.
} 
Such behaviour could be a legitimate practice by a threatened state, but the Western regime in Byzantine lands is called a tyranny, while Epiros and Nikaia, implicitly present, are not, and there is no mention about a similar practice followed by them.

Furthermore, their citizens, Apokaukos and Germanos II are the sufferers of the Latin practice, which destabilizes the legitimacy of the actions of the Latin regime. So, the image of an oppressive Latin system, impairing the rights of the citizens of two sovereign, supposedly not oppressive, Byzantine states unfolds, implying a marked difference between the modi vivendi of the Byzantine and the 'Italian' regimes.

Condemnation of Western attacks and rule over the Byzantines also appear in more poetical forms, just like the idea of revenge. In another letter to Theodoros I Komnenos Doukas, whom he addresses as emperor, Apokaukos presents the case of a pious monk, who was knocked out of his kellion by the cruel peg of the Latin abuse. "Even if he [the monk] 'pegged back' the Latins many times with the righteousness of his behaviour, but the one [needle] of those proved to be strong and lead him [the monk] out of his own kellion. ${ }^{129}$

The monk mentioned by Apokaukos can be identified with the hieromonachos Ioannikos. ${ }^{130}$ The equation of his ill-treatment by the Latins with being knocked out by a cruel peg, on the first hand, is a possible playful reference to a fragment of Aristophanes from the Merchant Ships (O$\lambda \kappa \alpha \dot{\delta} \varepsilon \varsigma)$ ), ${ }^{131}$ while, on the other hand, an effective device of the suggestion of violence to the audience.

The charge that a monk, who is presumably a very pious person, was ejected form his humble cell (kellion) via the Latin abuse, doubtlessly brands the behaviour of the Latins as rightless. Moreover, the claim that the monk 'pegged back' the Latins many times with his righteous conduct depicts Ioannikos as morally superior to his abusers, suggesting that he responded with exemplary Christian behaviour to their attacks, and that he achieved moral victories over the Latins with these deeds, which irritated them.

It is an important circumstance that there is no mention of the Latin authorities reacting to the abuse, but it is Apokaukos, who petitions for the displaced monk at Byzantine authorities. It supports an interpretation that the Latin authorities did not care about the abuse, or it even

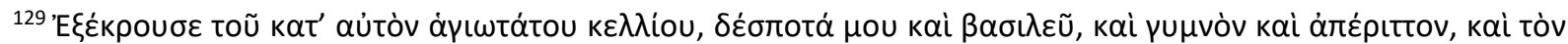

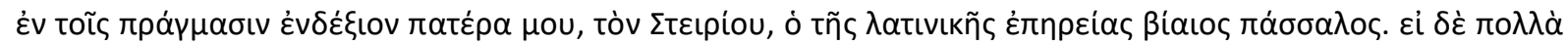

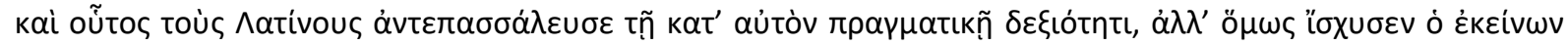

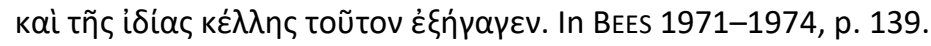

${ }^{130}$ BEES 1971-1974, p. 221.

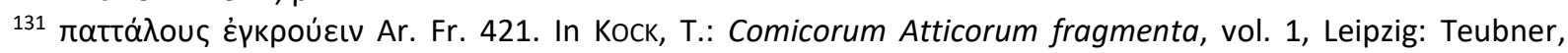
1880, p. 501.
} 
happened by their order. Both are characteristics of autocratic systems, in which members of the elite can violate the rights of other citizens with impunity or it is the regime itself that harasses innocent people for dubious reasons. Meanwhile, the petitioned Epirote government, by the very fact of the petition, is supposedly inclined to help the mistreated Ioannikos.

Furthermore, the portrayal of the events also bears a definite resemblance to the standard representations of Christians martyred or persecuted because of their faith, which enhances the impression of an oppressive Latin government mistreating its Byzantine citizens, possibly for their Orthodox faith. Regardless of the reasons behind the forceful eviction of Ioannikos, a strong boundary is established between him, an innocent Byzantine violated in his basic rights, and the depraved Latins, who rightlessly evicted him from his cell, just like between the Epirote court inclined to justice and the Latin regime with its oppressive tendencies.

It was not the last letter of Apokaukos addressed to Theodoros I Komnenos Doukas. Another one of them defined Italian oppression similarly by one of the negative traits often attributed to it by $13^{\text {th }}$-century Byzantines. Apokaukos, frequently insulted by the local Epirote authorities, writes to Theodoros I in hope of an intervention on his own side. After praising the philanthropy of his sovereign, Apokaukos turns to his military achievements.

As the metropolitan archbishop dramatically claims, God has crushed the molars of those anthropomorphic lions through Theodoros and may he [God] make them [the lions] absolutely disappear, so that he [Theodoros] may have good fame until the times are recorded, and so he [Apokaukos] may shake off the obedience of the harmful bond and achieve his former unenslaved freedom in the next step. Let it be, that the churches and cities and all that belong to the Empire receive clearing and sanctification instead of the Italian defilement. ${ }^{132}$

Apokaukos here designates Western rule not by name, but by one of its perceived major characteristics, that is, its brutality, attributing to it the common Byzantine epithet, 'Italian'. The image becomes even more vivid by mentioning anthropomorphic lions facing Theodoros I and God, which are clearly equivalents of the hated Latins. The lion had already been traditionally a symbol of ferocity and cruelty in Byzantine culture, ${ }^{133}$ strengthening the

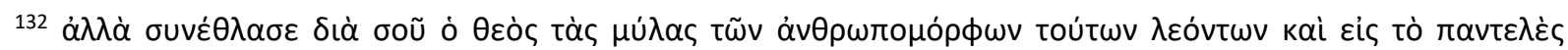

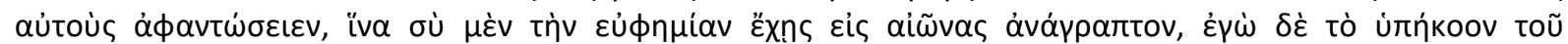

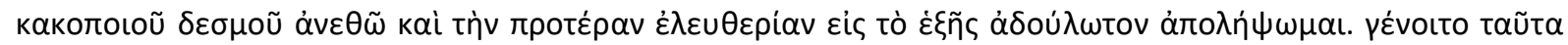

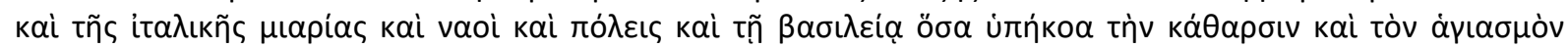

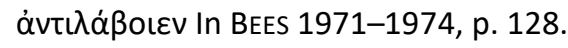

${ }^{133}$ SCHMIDT, Tristan: Protective and Fierce: The Emperor as a Lion in Contact with Foreigners and his Subjects in Twelfth and Early Thirteenth-Century Byzantine Court Literature. In STEWART, Kirsty - WAKELEY, James Moreton (Eds.): Cross-Cultural exchange in the Byzantine World, c. 300-1500 AD. Byzantine and Neohellenic Studies vol.
} 
invocation of Latin brutality, while partly dehumanizing the Western conquerors at the same time.

As they are depicted as similar to wild animals, humans in their appearance only, extreme acts of violence are justified sanctions against them, represented by the metaphor of crushing their molars and making them completely disappear (suggesting that the Epirote ruler ruthlessly wiped them out after defeating their forces). This justification becomes the more pronounced by the claim that God himself assisted Theodoros in crushing the molars of those Latin lions, attributing their utter demise to divine support.

The claims that Theodoros Komnenos Doukas and his Byzantine forces obviously assisting him were justified in their countenance against the 'brutal' Latins and were favoured by God in their fight also show them being much better than the Latins in this respect, devoid of Latin brutality and not at all similar to raging lions. The boundaries implied by the source are presented in the fields of tendencies for animalistic brutality, right to violence against the other party and divine favour. In in all three cases it is the Byzantine party which is featured as having a far higher standing.

References to Western oppression were not limited by Apokaukos to letters written to his sovereign. In a letter from 1217-1218, written to Euthymios Tornikes, he praises his correspondent as being able to console populous cities that were antagonized by Italian bitterness. ${ }^{134}$ The cities in question seem to be Athens, Thebes and Euripos, frequented by Tornikes, whom Apokaukos, his friend, missed greatly and repeatedly attempted to convince about settling in Naupaktos, which Tornikes finally did in $1219 .{ }^{135}$

Regarding these actions of Apokaukos, the reference to the talent shown by Tornikes to console cities suffering from Western rule is not only a criticism of Latin domination, but a gesture of understanding the 'noble occupations' of his friend that prevent him from joining the archbishop in Naupaktos. But the criticism of Latin rule over Attica and Euboia and the praise of Tornikes also imply a marked difference between the Byzantines and the Latins. The embittered state of the cities frequented by Tornikes is attributed to Latin bitterness ( $\dot{\varepsilon} \xi$ i $\tau \alpha \lambda \imath \kappa o \tilde{~} \dot{\alpha} \psi \imath v \theta \imath \alpha \sigma \mu о \tilde{v})$, which is a very vague term.

14. (2016) Edited by Louth, Andrew - Ricks, David. Peter Lang, Oxford - Bern - Berlin Bruxelles - Frankfurt am Main - New York - Wien, pp. 159-173, pp. 167-168.

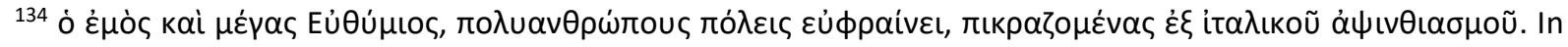
BEES 1971-1974, p. 104.

135 DARROUZES, Jean: Notes sur Euthyme Tornikès, Euthyme Malakès et Georges Tornikès. REB 23 (1965), pp. 148-167, pp. 153-154. 
However, the contexts of the epistolographic corpus of Apokaukos and the historical situation support an argument, namely that it should be interpreted as a generally oppressive Latin regime, limiting the opportunities of its Byzantine subjects. Tornikes consoling the locals suffering under this Latin rule is also a symbol of Byzantine values and a supposedly very different Byzantine style of governance, understood as clearly superior to the Latin system.

Moreover, among the many possible consolations which he may offer a very potent one is definitely the hope of liberation from the Latin regime, its most probable source being the army of Epiros. Even if they remain mostly implicit, the condemnation of 'Italian' rule and its unfavourable comparison to Byzantine rule are present in the source.

The third remarkable personality of the contemporary Epirote ecclesiastical elite besides Apokaukos and Bardanes, is Demetrios Chomatenos, archbishop of Ochrid, who had also written about Latin oppression against Byzantines. In one of his letters, he discusses the question of the acceptability of following the Latin habits in difficult times. ${ }^{136} \mathrm{He}$ refers to the Athonite monk, Gregorios Oikodomopoulos, who was asked to judge in a case presenting this very problem, and who turned to the expertise of Chomatenos to help him decide the case.

Until the Latin invasion of the Roman territories, in one of the monasteries of Athos, Greek and Iberian [that is, Georgian] monks lived together, following the rules of the founding father of the monastery, actually differing only in their languages. But the Latin power and the division caused by it made their community collapse. ${ }^{137}$ The detail that Georgian and Greek monks lived together makes it clear that the Iviron is the Athonite monastery in question. ${ }^{138}$

Even the very beginning of the story sets up a definitely tendentious narration. The lives of the monks are presented as ones living up to the Orthodox monastic ideals. But Chomatenos writes that it was the state of affairs until the Latin invasion, strongly suggesting that it had unfortunately changed after the foundation of the Latin Empire. And indeed, it is stated that the Latin power and the internal conflict generated by it undid this idyllic state.

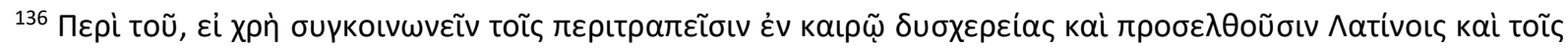

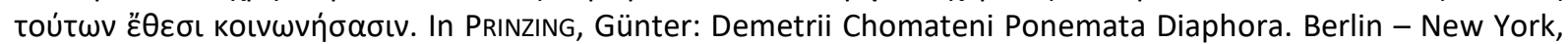
Walter de Gruyter, 2002, p. 198. 54th letter. Henceforth PRINZING 2002.

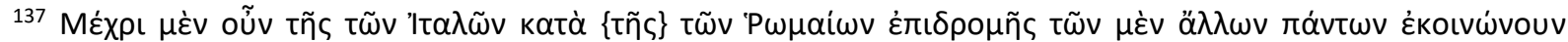

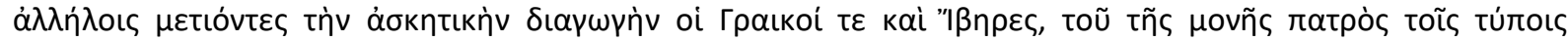

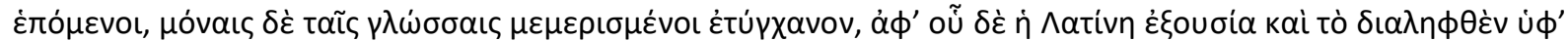

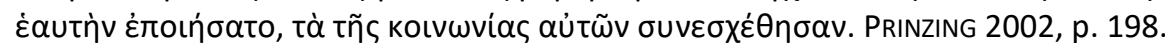

${ }^{138}$ NICOL 1957, p. 81.
} 
Latin rule, as an abstract, malevolent force, appears as a cause of division within Byzantine society and that destroys a faithful Orthodox monastic community.

As Chomatenos states, many violent acts were committed by the agents of the 'Italian Church' to make all the priests and monks 'by us', that is, in the conquered Byzantine lands, to come under the power of the Roman pope, and, as a consequence, to mention his name on the occasions, when the memory of the archbishops is used to be remembered at the altar, and to follow the habits of the Roman Church. ${ }^{139}$

In this presentation, the Latins attempt to coerce the Greek clergy into joining the Catholic Church, and they easily turn to violence to achieve their goals, committing numerous violent acts against their seemingly peaceful victims. It all fits well to the traditional image of the persecutors of Christians for their faith, while suggesting that Catholics neither have valid arguments nor practice Christian morality, and that is why they persecute those who reject their credo. It is worth mentioning that Chomatenos chose an interesting solution to describe those practices of the Catholic Church that the Orthodox perceived as erroneous. He comments on the Catholic habits in general and brings only one into the limelight: that is, the question of papal primacy.

As the letter states it, the Georgian monks of the community did not withstand force, but, caring little, disgracefully went to Thessalonike, to the cardinal ${ }^{140}$ of the Roman pope and subjected themselves to the will of the Pope, following the Latin habits. They immediately showed the sign of communion, voluntarily putting their hands into the hands of those ones [the Latins], thus blurring the common life with the Greek monks and making it turbid. ${ }^{141}$

The archbishop of Ochrid contrasts the behaviour of the Georgian monks with the attitudes of all those Orthodox who resisted the Latin demands. Persons blessed and worthy of numerous encomia did not obey the lawless violence of the Latin rule to change their [the Orthodox] holy habits. But, giving up their bodies to ill-treatment and spitting upon what was inflicted to them, to avoid becoming traitors of the habits of their fathers, [these] brilliant

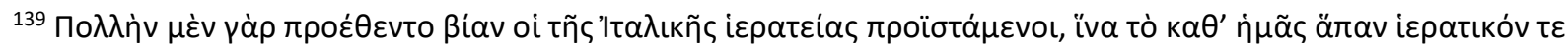

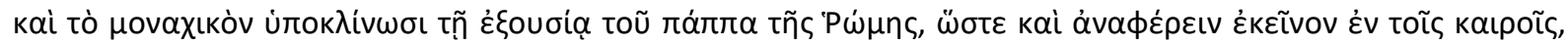

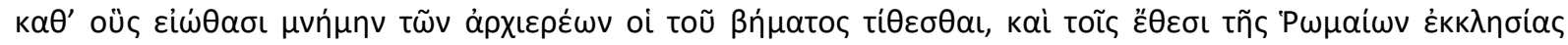

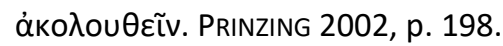

${ }^{140}$ The cardinal in question is most probably Benedict of S. Susanna, who participated in the debates about the Union of the Catholic and Orthodox Churches that were held in the Latin Empire between 1205-1207 and visited Thessalonike in autumn 1205 and at the end of 1206. PRINZING 2002, p. 134.

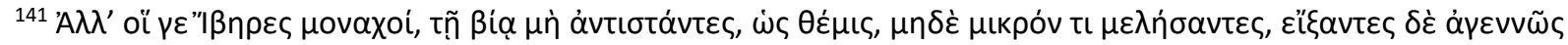

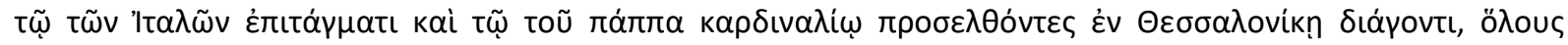

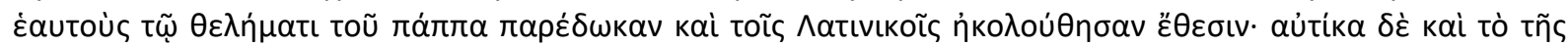

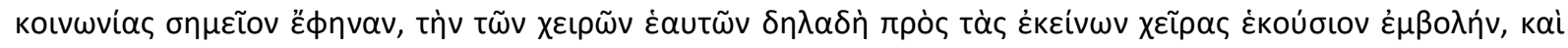

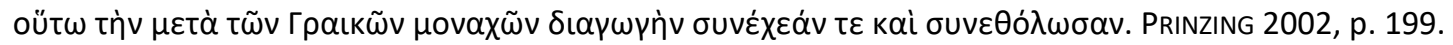


martyrs brilliantly shined with their preference. And, as it is well-known for the readers, for the ones who fight in a way pleasing to God, for the ones who kept the faith, the wreath of righteousness will be weaved. ${ }^{142}$

The argumentation of Chomatenos here seems to follow a strong tradition within Byzantine heresiology. That is, first the author describes the practice he deems religiously problematic, then he attempts to demonstrate it erroneousness. ${ }^{143}$ As Chomatenos was a canon jurist and an authority on theological issues, writing with a didactic aim, it was probably a deliberate solution. Beyond this, he draws a strong dichotomy between bodily and spiritual well-being, emphasizing that the martyrs suffered in their body, but their souls deserved the wreath of righteousness.

As he uses the word 'martyrs' and closes his train of thought with a paraphrase from 2 Timothy, ${ }^{144}$ in which the author appears in the process of evaluating his life at its end, his texts suggests that the faithful he mentions were murdered for their resistance. It increases the dramatic effect, and the supposedly theologically educated audience of the letter probably recognised the paraphrased text of the New Testament.

Chomatenos is adamant in his verdict. It is impossible for the Greek monks the commune in anything with the Georgian ones, and with all of those, who share their opinion, as they had intercourse with the Italian habits and dogmas, that were rejected by their Holy Church [the Orthodox one]. This harsh judgement can only be annulled if the Georgians repent their sins, deny the Catholic credo and accept the Orthodox credo once again, because the Orthodox Church follows the habit of philanthropy. ${ }^{145}$

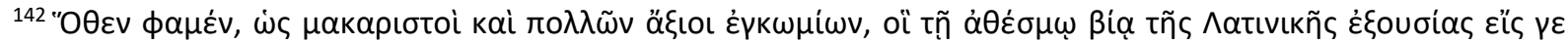

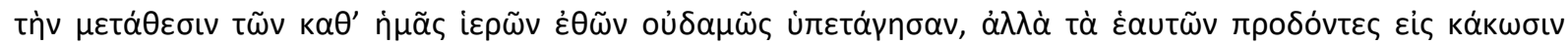

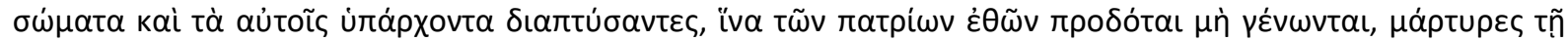

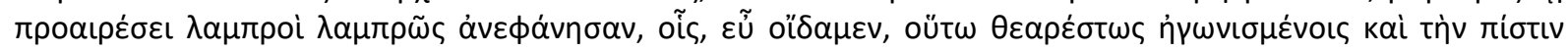

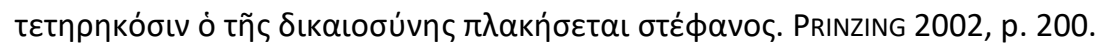

${ }^{143}$ CAMERON, Averil: How to Read Heresiology? In Journal of Medieval and Early Modern Studies, 33:3, Fall 2003, pp. 471-492.

1442 Tim 4, 6-8: "As for me, I am already being poured out as a libation, and the time of my departure has come. I have fought the good fight, I have finished the race, I have kept the faith. From now on there is reserved for me the crown of righteousness, which the Lord, the righteous judge, will give me on that day, and not only to me but also to all who have longed for his appearing." (In every case when I quote the Bible, I do that according to the New Revised Standard Version. Metzger, Bruce Manning (Ed.): The Bible. New Revised Standard Version with the Apocrypha. Division of Christian Education of the National Council of the Churches of Christ in the USA, 1989. Henceforth NRSV. - Zoltán Szegvári.)

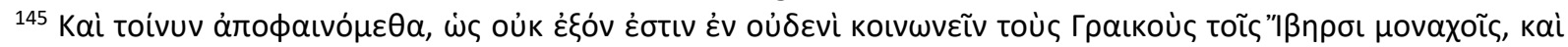

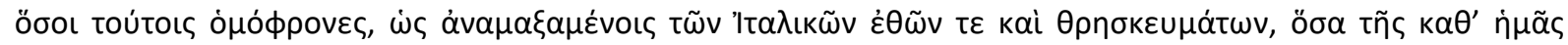

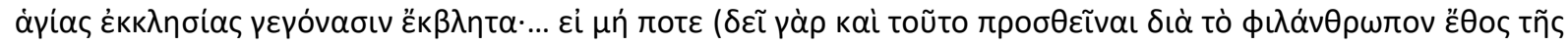

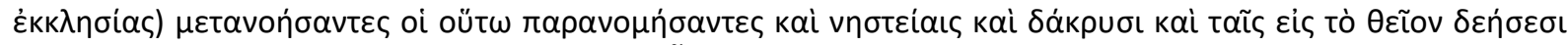

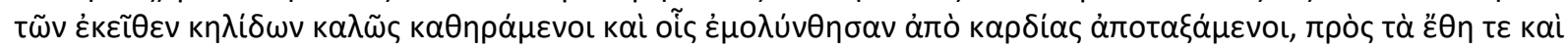

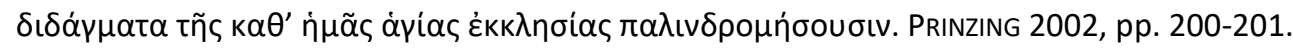


Stressing the error of the Georgian monks and complete repentance as the only way of their readmission into the Orthodox Church and the Iviron monastery is probably not only a matter of 'heterodoxy'. The Byzantine culture of Orthodoxy traditionally tended to link heresies not only to base morals but also to political disloyalty. ${ }^{146}$ The communion of the Georgians with the Catholic Church could have been interpreted by contemporary Byzantines as a compromise of their loyalty to the defunct Byzantine Empire, pledging their allegiance to two foreign powers at the same time: the Papacy and the Latin Empire.

Here it should be noted again that papal primacy is the sole 'problematic' Catholic dogma that Chomatenos explicitly mentions, otherwise writing on Latin habits in general. As the themes of domination and oppression are very emphatic in the text, the political dimension of heresy may be implicitly present, emphasized by the reference to papal primacy and the gestures of reverence connected to it (mentioning the pope in certain rituals).

In the case of the references to philanthropy and repentance as reasons behind a possible redemption for the 'apostate' monks, the case is far clearer. The pure love of God for mankind was a core tenet of Byzantine Orthodoxy and preached that every good Christian thrives to emulate this love in his life towards others. In a strong connection to this concept, the Orthodox Church had a special function as a place of healing for errand souls, and every spiritual 'malady', even apostasy could be cured in this 'hospital'. The only important conditions were the acknowledgement of the sin committed and the due repentance for it. ${ }^{147}$

So, the opportunity for redemption offered by Chomatenos is far from an individual opportunity, but very much a reiteration of an important teaching of the Orthodox Church. This, with the description of Catholic abuses, suffered by the peaceful Orthodox believers, at the very same time underlines the moral superiority of Orthodoxy over Catholicism and the Byzantine followers of the former over the Latin followers of the latter.

That moral superiority represents itself as Catholic Latins turn to violence and other devices of coercion to force their own faith upon the Orthodox Byzantines, who do not harm their abusers, but adamantly oppose their attempts. The Byzantine ethnicity of the latter group is stressed by the fact that the monks who resisted Latin pressure are designated as Romans, while the apostates are identified as Georgians.

\footnotetext{
146 Magdalino, Paul: Orthodoxy and Byzantine Cultural Identity. In Rigo, Antonio - ERMILov, Pavel (Eds.): Orthodoxy and Heresy in Byzantium. The Definition and the Notion of Orthodoxy and Some Other Studies on the Heresies and the Non-Christian Religions. Università degli Studia di Roma "Tor Vergata", 2010 pp. 21-40, p. 29.

147 Constantelos, Demetrios J.: Poverty, Society and Philanthropy in the Late Medieval Greek World. New Rochelle, Aristide D. Charatzas, 1992, p. 40.
} 
In spite of the efforts of Chomatenos, it seems that the verdict did not reach its goal, falling on deaf ears. Until the Epirote conquest of the Chalkidike-peninsula, the monasteries of Athos officially existed under the ecclesiastical control of a Latin bishop, whose see can be identified as Sebasteia or Samaria. The monasteries all refused to accept the jurisdiction of the Catholic bishop - except Iviron. ${ }^{148}$

The above mentioned letter by Gregorios II Kyprios to the protosebastos and protobestiarios, Thedoros Mouzalon, also deals with the problem of Latin oppression, and does it explicitly. As the patriarch urges the authorities to act on the behalf of the threatened Byzantine merchants, he states that it seems necessary to him to dispatch imperial warships against those Genoese [against the ones who turned to piracy] and to send letters to the local [Constantinopolitan] leaders of the Genoese community, that forbid attacks on the sea and command to cease the tyranny against others, which is completely unnecessary to be displayed against their ones [the Byzantines]. [The Genoese pirates] rush into the ships, sail to those who want to trade, steal like if they would be some kind of owners of everything, all but thrust headlong to their [of the Byzantines] ships and sink them so that only they [the Genoese pirates] have passage and profit. ${ }^{149}$

To begin with, these lines of the patriarch suppose a certain collective responsibility: according to Gregorios II, if the emperor acquires letters from the leaders of the Genoese community in the capital, in which they forbid piracy and the harassing of other seafarers, it will diminish the number of pirate attacks committed by the Genoese. If someone does not believe that the Genoese simply did not know it earlier that piracy was illegal under Byzantine law (as it had to be most evident for them), then this advice implicitly claims that at least a sizeable part of the Genoese community in Constantinople, including its leaders, knew well who among their compatriots had turned to piracy, and they could prevent it in the future if they would have experienced pressure to do so.

Furthermore, Genoese piracy is described besides 'attacks on the sea' as 'tyranny'. That points to an interpretation of maritime raids committed by those hailing from the Ligurian city as part of an oppressive system, operating with the intent of violating the rights of others with

\footnotetext{
148 FINE 1987, p. 79.

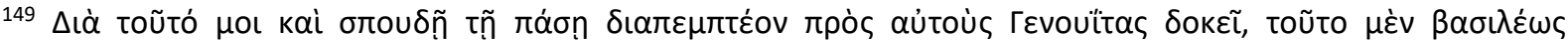

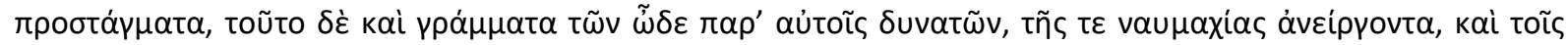

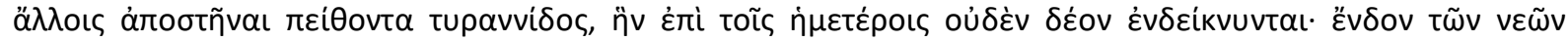

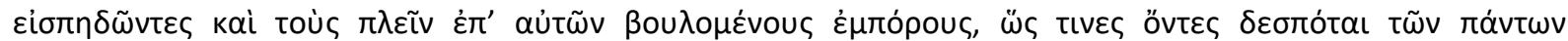

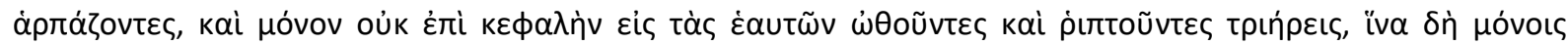

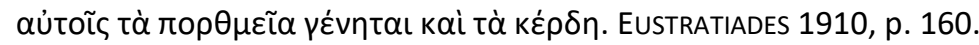


the intent of gaining profit. It is corroborated by the following sentence, which states that the intent of the pirates was that only they could have a passage in the Black Sea and own the profit accompanied by it, suggesting a vision of a Genoese monopoly of Pontic trade in the formation.

It also supports that Gregorios II supposed a certain collective responsibility of the Genoese in Constantinople, as such an operation, if it would have existed, would had logically involved a high number of participants, making it unlikely, that a sizeable part of the inhabitants of Galata would not have been at least aware of these nefarious activities.

The reality of the claims of the patriarch about Genoese piracy at a large scale pose an interesting problem. The $13^{\text {th }}$ century saw a rise in the importance of the Black Sea Region in the grain supply of Italy, and the main intermediaries of this commerce were Genoese and Venetian merchants, acquiring great profits for themselves in the process. ${ }^{150}$ Achieving a hegemonistic Genoese role in this trade would have meant invaluable profits for those participating in it.

However, the cooperativeness of the Byzantine government was of great importance to keep the routes of supply continuously open, and such a policy against their Byzantine competition would have seriously threatened to provoke an action of the imperial governement against Genoese trade, which could have had a disastrous effect on Genoese interests, both private and state ones. It is also hard to imagine that the Venetian competition could have tolerated any Genoese attempts to reckon the market in such a scale, as it would have threatened their long-term business interests.

Therefore, although it is very probable that certain Genoese merchants have turned to piracy to discourage their Byzantine competition, the claim made by Gregorios II about their intent on making Black Sea trade their own privilege should rather be understood as a rhetoric hyperbole, intended to provoke governmental action, instead of a real Genoese objective.

The presentation shows another curious element. Besides the victimised merchants, the honour of the Byzantine state, and of the emperor himself, is portrayed as being under attack by the pirates, and all of them on a large scale. This is hardly accidental, but rather a conscious device to provoke state officials to take piracy seriously and counter it effectively. ${ }^{151}$ The suggested proposals to change state policy were futher expedited by

\footnotetext{
${ }^{150}$ LAIOU, A.: Monopoly and Privileged Free Trade in the Eastern Mediterranean. In LAIOU, A.: Byzantium and the Other. Relations and Exchanges, Farnham, 2012, pp. 511-526, pp. 522-523.

${ }^{151}$ LAIOU, Angeliki: The Correspondence of Gregorios II Kyprios as a Source for the History of Social and Political Behavior in Byzantium, or on Government by Rhetoric. In SEIBT, Werner (Ed.): Geschichte und Kultur der
} 
Andronikos II (1282-1328) having disestablished the powerful fleet he inherited from his father and predecessor, Michael VIII (1259-1282), thus making his empire extremely vulnerable against maritime threats. ${ }^{152}$

Patriarch Georgios II also defines clear differences between the Genoese and the Byzantines. The Genoese are portrayed as engaged in a type of 'naval tyranny', resorting to piracy to achieve a hegemonic position in Black Sea trade. The victims of this behaviour are the Byzantines, depicted as peaceful, law-abiding seafarers devoid of malevolent intent similar to those of the Genose pirates.

As it has been discussed above, the patriarch also generalises these traits to a great extent. He argues for the existence of widespread Genoese involvement in the atrocities, and supposes a form of collective responsibility among the Genoese of Galata, while the entire Byzantine merchant community engaged in Black Sea trade is understood as being in grave danger. Furthermore, the infringement of imperial rights is another serious concern for the patriarch: Genoese piracy is an attack on the authority of the emperor and sovereignty of the Byzantine Empire regarding the Black Sea.

In other words, the boundaries between the two ethnic communities appear in two fields, the proneness to violence, which is more particular, and the respect of the rights of others, which is more general. The Genoese of Galata are in both respects portrayed as definitely the inferiors of the Byzantine merchants on the Black Sea.

One of the numerous correspondents of Nikephoros Gregoras, Gregorios Akindynos, a central figure in the Palamite controversy, offers a different representation of violent conflicts between the Catholics and the Orthodox. In one of his letters, addressed to the philosopher Gregoras and sent to Constantinople in the spring of 1345, Akindynos serves with a vehement speech against Gregorios Palamas, his main theological opponent, and heavily relies on disparaging the morals of Palamas to support his own argumentation. Towards the end of the letter, the Latins play a rather interesting part in the condemnation of Palamas.

Akindynos claims that Palamas repeatedly attempted to convince the Latins of Galata and the grand master of the Hospitallers of Rhodes ${ }^{153}$ about the piety of his teachings, utterly

Palaiologenzeit. Wien, Verlag der Österreichischen Akademie der Wissenschaften, 1996, pp 91-108, p. 101. Henceforth LAIOU 1996.

152 ANGold, Michael: Michael VIII Palaiologos and the Aegean. In SAINT-GuILLAIN, Guillaume - StATHAKOPOULOS, Dionysios (Eds.): Liquid and Multiple. Individuals and Identities in the Thirteenth Century Aegean. Paris, ACHCByz, 2012, pp. 27-44, p. 43.

153 Following the date of this letter by Akindynos, the Hospitaller grand master mentioned is identifiable with Hélion de Villeneuve, who hailed from Provence, and held the office of grand master from 1319 to 1346 and 
failing every time. And, after he did that, he keeps accusing and slandering those Orthodox who were subjugated to the Latins by war, yet dare to openly debate with their theology, merely because they reject the doctrines of Palamas. ${ }^{154}$

This section fits well into the context of the letter, which attacks both the theology and the moral integrity of Gregory Palamas. The leader of Hesychasm is presented as a hypocrite, who attempted to gather Latin support for his cause, but, after he had failed to achieve that, he turned to accusing those Orthodox believers who had to live under Latin rule with impiety, despite the courageous behaviour presented by those oppressed people. ${ }^{155}$

Besides condemning Palamas for his alleged hypocrisy, this section presents another dichotomy of the oppressed Byzantines and their Latin oppressors. Akindynos states that the unfortunate souls about whom he is writing are under Latin rule, yet they openly refute Latin teachings, which could hardly be called bravado, if it could not potentially lead to Latin retaliation. It is also important that the origin of this Latin dominance is identified with war, further augmenting the motive of Latin violence in the text.

It is suggested that the Latins who ruled these territories inhabited by an Orthodox majority are warlike conquerors with a tendency to retaliate if their Orthodox subjects criticise their religious views. Meanwhile, it is also implied that their Orthodox subjects offer many examples of courageous, outspoken criticism against the Catholic dogmas, conquering their fear of harsh punishment and, supposedly, often suffering such retribution for debating the Latin teachings, yet without any sign of resorting to violence. They, including many Byzantines leaving under Western rule, are presented as innocent victims of Latin oppression for confessing their religious views, which are implied to be 'better' than the respective views of their Catholic rulers.

It is interesting to see, however, how the Latins occupy a moral position between Palamites and what Akindynos perceives as 'Orthodoxy'. Earlier in the letter, he points out

led two campaigns against Smyrna, to curtail Turkish piracy in the Aegean, in 1334 and 1344. For these campaigns, see LEMERLE, Paul: L'émirat d'Aydin, Byzance et l'Occident: recherches sur "La geste d'Umur Pacha", Paris, Presses Univ. de France; 1957, pp. 91-100, pp. 180-203.

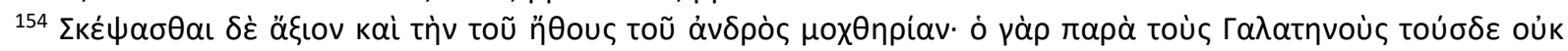

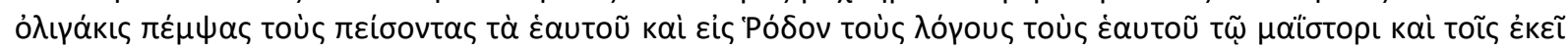

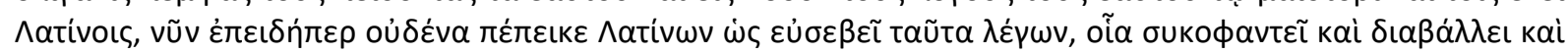

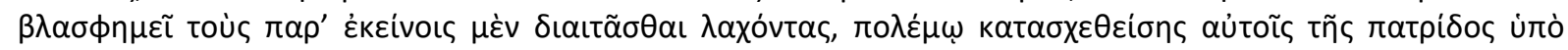

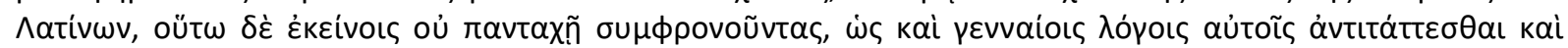

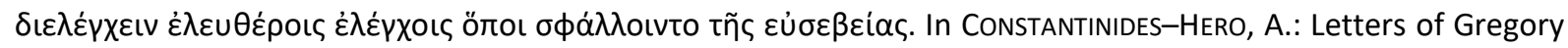
Akindynos [Corpus Fontium Historiae Byzantinae. Series Washingtonensis 21. Washington, D.C.: Dumbarton Oaks, 1983]: 2-304. p. 192. 44 ${ }^{\text {th }}$ letter. Henceforth CONSTANTINIDES-HERO 1983.

${ }^{155}$ CONSTANTINIDES-HERO in her commentary links this remark to the debate between Lapithes, who was a friend and theological supporter of Akindynos, and Hugh IV (1324-1358) of Cyprus and his scholars. In COnStANTINIDES-Hero 1983, p. 384. 
that none of the patriarchates accepted the hesychast teachings, naming them by their sees, and, after that, he states that Rome has rejected these doctrines too. Later, the text mentions the rejection by the Genoese of Galata and the Hospitallers of Rhodes. This way, Catholicism and Latins acquire a certain amount of moral authority in the context of the letter. Though they are not accepted as equal to the Orthodox in their theology, yet they are presented as ones standing above the Palamites nonetheless. The fact that the two Latin communities explicitly mentioned cultivated a rather positive relationship with the Empire in this period further reinforces this impression. ${ }^{156}$ Akindynos seems to rely on a very traditional technic of denigration: he underlines that not only the faithful Orthodox, but even the (from the Orthodox point of view) heterodox and traditionally despised Latins rejected the Palamite doctrines, suggesting that these teachings are even more abominable than the 'errors' of the Latin Church. Therefore, it implies the necessity of showing a rejection against Palamism that is even firmer than the one shown against the Latin dogmas.

Ioannes/Ioseph Bryennios (c.1350-1431/1438) commented on Latin violence against Orthodox believers a generation later, writing to Ioannes Syrianos from Crete. Bryennios cites six reasons that he appealed to the Emperor and the Patriarch before travelling to the island of Cyprus. From these, the third and fourth ones are worth examining, because both of them designate the Latin threat as an important motivation.

The third reason mentioned by Bryennios was that the Latins hearing about it [his journey], relying on a spy, gathering the information about what he [Bryennios] did in Crete, becoming his implacable enemies, will be suspicious to him and everything [Bryennios will do] after that. Besides, his fourth reason was that he, falling into the hands of the 'Frankish bishops', will be an object of malignant joy for his enemies.

These claims have multiple implications. The island of Cyprus was ruled by the House of Lusignan as well as a Catholic minority elite since 1192, and tensions between them and the Greek majority were often high. ${ }^{157}$ So, the claims brought up by Bryennios about the anticipated suspicion of the local Latins, the possibility of those persons becoming his

\footnotetext{
156 The relationship deteriorated dramatically after the victory of John VI Kantakouzenos (1347-1354) in the civil war of 1341-1347, in connection to his open support for Palamism. The Genoese and the Hospitallers turned against Byzantium and unsuccessfully attacked Constantinople in 1348, early after the ascension of John VI to the imperial throne. In Nicol, Donald M.: Byzantine Requests for an Oecumenical Council in the Fourteenth Century. Annuarium Historiae Conciliorum I (1968), pp. 69-95, pp. 83-84.

${ }^{157}$ ASDRACHA, Catherine: Cypriot Culture during the Lusignan Period. Symmeikta 9 (1994), pp. 81-93, esp. pp. 8889. Henceforth ASDRACHA 1994.
} 
implacable enemies, and the danger of the Frankish bishops prosecuting him, could hardly be dismissed as baseless fears.

Besides, these excuses could seem to be credible and sound reasons in the eyes of the Byzantine authorities corresponding with the author, to whom Bryennios refers as the 'emperor' and the 'patriarch'. These references to the high notabilities demanding his departure may serve as apologies for his eventual travel to Cyprus despite all of his reservations, and as devices to strengthen and validate the seriousness of these reservations at the very same time.

Later in his letter, Bryennios expounds the expectable difficulties of holding masses in Cyprus, claiming that he did not go there to go away, but to die. After claiming that holding masses either openly or secretly will be perilous or impossible, he begins a thought experiment. According to the hypothesis, let it be possible, to hold masses openly, as those [the Latin authorities] will comply with everything they [Bryennios and his fellow priests] want. Let a place pass by for the freedom of speech of that liturgy. There will be, as Bryennios thinks, straight in the liturgy or after they finished the liturgy, an open disturbance and strife will follow it against those who profess heresy and the archons of the area.

What ensues from this, asks Bryennios? They [him and his fellow priests] will suffer badly, and those too who dared to join their mass and are unwilling to deny what they beware to agree with them [Bryennios and his fellow priests] due to force. And for all the people because of those who acted unavailingly with them [Bryennios and his fellow priests], persecution will follow, and confusion. The clerics one after another not returning to the City anymore will be discussed in the whole of Cyprus as really treacherous and malignant ones.

In this segment, Bryennios hits a very dark tone with the statement that he went to Cyprus to die, creating a strongly pessimistic, dark ambience. Just after that, he presents his thought experiment on the possibility of open Orthodox masses in the Lusignan Kingdom of Cyprus with barely hidden irony, turning the tone into tragicomic. His imperatives ('let it be', 'let a place pass by') and unusual use of words ('will comply' for the behaviour of the Latin authorities), are the main devices of his irony and the sources of this atmosphere.

The images of open strife and violence erupting after the end of their first mass, or even before it, identifying the opposition of the implicitly present Orthodox as 'those who profess heresy' and the 'archons', have multiple implications. First of all, it implicitly refers to the social stratification of Latin Cyprus, as the archons ('leaders') appear as natural supporters of 
the Catholic Latin side, which is most understandable, regarding their Catholic and mostly French identity. ${ }^{158}$

Furthermore, tolerance from the side of the Catholics is excluded as a possible outcome. In the presentation of Bryennios, the Latin side will definitely react with intolerance and violence. Their predictable victory is not mentioned explicitly but is clear by the images of the martyrdom of the Orthodox priests and their loyal stock in the hands of the Latins. The final tragedy is the prediction that they are the martyrs who will be condemned by the survivors and not the perpetrators.

As his train of thought continues, that will happen, if they hold the liturgy openly. And if they do it in secrecy, which is at least inconvenient, there will have to be a way to identify this practice, either with corresponding words or the hands will meet. Many of those, who will be suspects of apostasy because of this, will be investigated, imprisoned and given to death. And they [Bryennios and his fellow priests], will be searched for because of the faith and life of those [the aforementioned faithful people] and will die as plotters.

And if they hide everything, that is at least impossible, nothing will be accomplished and finished, except if their earlier fraud or their [of the Latins] boasting against them [Bryennios and his fellow priests] and the blame of the common people will make them [Bryennios and his fellow priests] to commune with them [the Latins], without a purpose and in vain. If they [Bryennios and his fellow priests] refuse to commune with them because of their doctrinal failings, that is, with the Franks and the Genoese residing by them [the Greek Cypriots]? For these [the Franks and the Genoese] it will seem, that they [Bryennios and his fellow priests] are surely spies, which will give the easiest pretext for the Frankish bishops to give them [Bryennios and his fellow priests] to death for being open enemies of their faith. ${ }^{159}$

The theme of the hostile Latins dominates in the aforementioned lines too, excluding any possibility of peaceful, tolerant behaviour from the side of the Latins. Hyperbolic as this solution may be, Lusignan Cyprus had a long history of oppression of its Greek Orthodox

\footnotetext{
158 For social stratification in Lusignan Cyprus, see ARBEL, Benjamin: The Cypriot Nobility from the Fourteenth to the Sixteenth Century: A New Interpretation. In ARBEL, Benjamin - HAMILTON, Bernard - JACOBY, David (Eds.): Latins and Greeks in the Eastern Mediterranean After 1204. London, Frank Cass, 1989, pp. 175-197, esp. pp. 176-178.

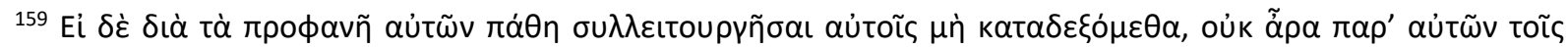

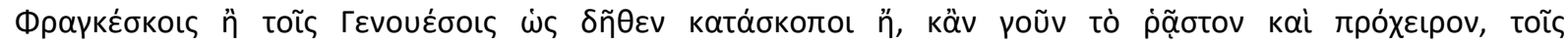

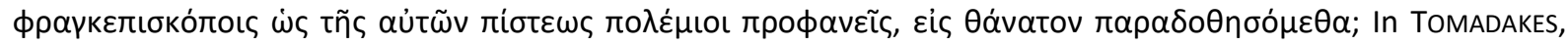

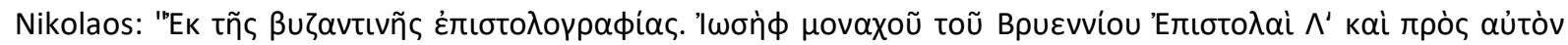

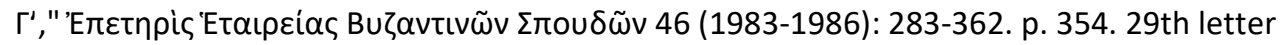


majority by its Catholic minority on denominational grounds, so it could seem that Bryennios had some reason to worry about his mission on the island. ${ }^{160}$

Bryennios supposes several boundaries between the Byzantines living in Cyprus, accompanied by the delegation led by himself, and the Latin population of the island. Social stratification is presented as having a strong ethnic character on the island, since the archons are identifiable as members of the Latin community, and the local bishops are designated as Franks. Meanwhile, there is no overlap between the Byzantine community and the local elit, further strengthening this impression.

Moreover, the Latin government of the island features many signs of a harshly oppressive regime. It is presented as highly intolerant towards Orthodox religious practices, demanding full communion between the local Orthodox Church and the Catholic Church, spying on the religious life of the local Byzantine populace, and even on the Orthodox religious authorities who travel to the island.

Furthermore, it is portrayed as brutally violent, ready to murder even clerics who are members of an imperial embassy and slaughter its own Byzantine subjects if its extreme level of control over Byzantine religious life seems to be even slightly challenged. Although not mentioned explicitly, but such harsh retaliation for minor offenses gives the impression that the tight Catholic control over Orthodox religious life on Cyprus relies on the brutality of the system, just like the very strong correlation between ethnicity and social status.

The Byzantines, on the other hand, are envisioned as an utterly oppressed community, who live under close control and are used to suffering astonishing cruelty for minor reasons. Their passivity and submissiveness are the results of their deplorable status, just like the possibility of many of them blaming the innocent victims, who provoked Latin aggression with their otherwise perfectly respectable behaviour, for the suffering of the wider Byzantine community.

The circumstance that there would be people who dared to defy the Frankish orders still implies a remarkable resilience by the majority population of the island. It stands even if only certain members of it behave this way, in secrecy and avoiding the use of force. The latter two characteristics also point to the dissenters showing caution. Regarding social status, the Latins are superior to the Byzantines on the island, but regarding the use of violence and oppressive tendencies, the situation is evidently the exact opposite, provoking strong moral judgements from the possible audience.

\footnotetext{
${ }^{160}$ For some notable atrocities committed by the Latins against the Orthodox on Cyprus, see HINTERBERGER 2011, pp. 139-141.
} 
A letter, written by Ioannes Chortasmenos to Bryennios, contextualizes the aforementioned mission of his correspondent, Ioseph Bryennios, quite interestingly. Around 1403, but surely before the summer of 1406, the Cypriot Orthodox bishops wrote a letter to the Patriarch of Constantinople, Matthew I (1397-1410), offering the possibility of reuniting the Church of Cyprus with the Church of Constantinople. The offer was definitely complicated by the circumstances. According to the so-called Constitutio Cypria, a bull issued by Pope Alexander IV (1254-1261) in 1260, the Orthodox bishops of Cyprus were subordinated to the local Catholic bishops that resulted in difficult circumstances for them and their flock, ${ }^{161}$ and the possibility of an amelioration of their situation probably played a role in their wish for a union with Constantinople.

On the other hand, Constantinople could have strengthened its influence through a union with the respectable Church of Cyprus. However, a union with a Catholic-influenced church may have seemed undesirable for many, including Bryennios, who was sent to the island as the leader of a delegation of three by the Patriarch to establish the union. He finally decided against fulfilling his mission, fearing the possible adverse consequences due to the subordination of the Cypriot Church to the Catholic Church. ${ }^{162}$ His decision led to his temporary fall from the grace of the imperial court. ${ }^{163}$ With his behaviour, Bryennios remained loyal to himself, being an ardent opponent of any compromise with the Catholic Church. ${ }^{164}$ His disdain for Catholics probably influenced claims about his and his fellow delegates' lives being threatened by the local authorities, mentioned in the previously analysed letter, and the credibity is rather dubious. ${ }^{165}$

In his letter, Chortasmenos hits a friendly tone towards Bryennios. As he explains, going through the letter of Bryennios, at the beginning, he laughed very much, as every time, when he hears these apologists, and, as Euripides says, the barbaric and ill-sounding cry of the passion hit his ears. ${ }^{166}$

\footnotetext{
${ }^{161}$ HUNGER 1969, p. 80; Gill, Joseph: The Tribulations of the Greek Church in Cyprus 1196-c. 1280. Byzantinische Forschungen V (1977), pp. 73-93, pp. 89-90.

162 His corpus suggests that he was not hostile to the Cypriot clergy in general. Bryennios wrote a friendly letter to Makarios, Orthodox archbishop of Famagusta in 1406-1407, from Constantinople. LOENERTZ, RaymondJoseph: Pour la chronologie des œuvres de Joseph Bryennios. REB 7 (1949), pp. 12-32, pp. 23-24.

163 BECK 1977, p. 749.

164 PLP 3257.

${ }^{165}$ See the earlier note on the theological debate between Lapithes, a friend of Akindynos, and Hugh IV of Cyprus. It was not without precedent that Constantinopolitan ambassadors visited the island with important ecclesiastical missions, and they were not abused by the Cypriot authorities.

${ }^{166}$ Eur. Or. 1385.
} 
But after that, contemplating over the case later and thinking about the loss of so many souls, his disposition toward them [the Cypriots] changed to the opposite, since he considered them [the Cypriots] as much more miserable than the others who are subiugated to the Latins, because in the case of the Cypriots, the aberration is accompanied by the evils of foolishness, and this pair has the power to lead down those who suffer from it to the bottom of Hades, as they say. ${ }^{167}$

These passages go further than the ones encountered before, prognosing extremely detrimental consequences of subordination to the Latins. Cypriots are designated as a community who suffer under the Latin rule. However, the real tragedy for them is hidden in the effects of this subiugation, as it leads to theological aberration and foolishness, which, as it is stated by Chortasmenos, are able to lead its victim to the very bottom of Hell, designated with its synonym, the Greek name of both the Underworld and its god, that is, Hades.

With regard to the image of the Cypriots kneeling in front of their Latin masters, while they are threatened by being banished to Hades, it is worth remembering that Byzantine depictions of the Last Judgement regularly portray Hades, who became an integral part of Byzantine depictions of Hell, with a damned soul sitting on his knee. ${ }^{168}$

Later in the same letter, Chortasmenos states that, from the beginning, there were bright hopes and everybody thought that those [the Cypriots] will annul there communion with the Latins, as it was indicated to them. ${ }^{169} \mathrm{He}$ recalls that there were certain persons, who accounted those who were going there [Bryennios and his fellow ambassadors going to Cyprus] as happy ones, if they were going to the garden of Alkinoos, but, as it seems, it was destined for the island to be filled up until excess with the rheum of the Latins, which, as he [Chortasmenos] thinks, is much more capable of destroying cities than the emanations of Aphrodite [Ourania], sending rays through the region of the Cypriots if one does not have to doubt the myth. ${ }^{170}$

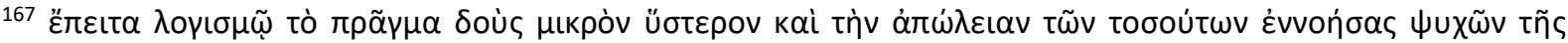

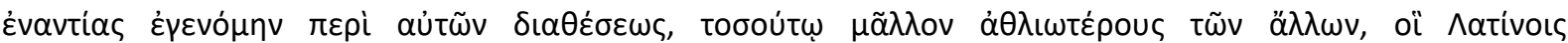

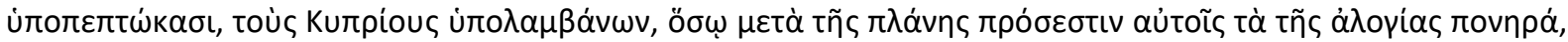

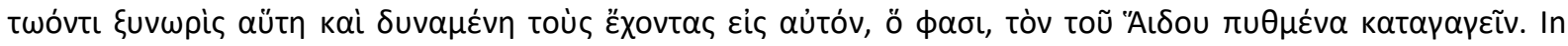
HUNGER 1969, p. 161.

${ }^{168}$ AlexIOU, Margaret B. - ŠEVČEnKo, Nancy Patterson: Hades. In KAZHDAN, Alexander - TALBOT, Alice-Mary (Eds.): The Oxford Dictionary of Byzantium. New York, Oxford, Oxford University Press, 1991, p. 891.

${ }^{169}$ A merely rhetorical first-person plural or a reference to the audience listening to the letter being read aloud?

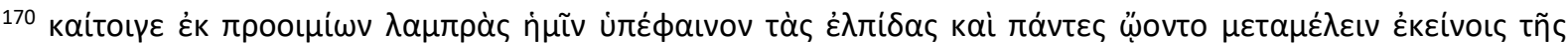

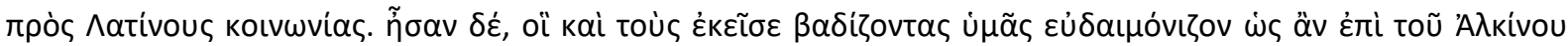

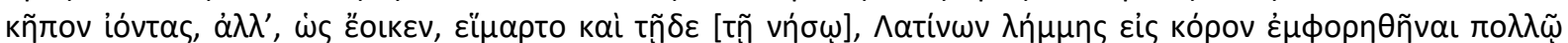

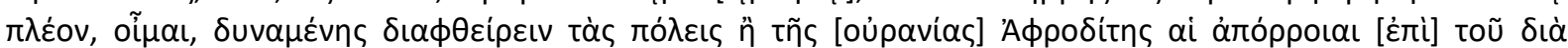


Chortasmenos here utilizes two classical Greek reminiscences for his argumentations, which is not an uncommon solution in a Byzantine letter, as mythological allusions were popular devices of Byzantine epistolography. ${ }^{171}$ The first of them is the garden of Alkinoos (king of the Phaiakians and father of Nausikaa) as a symbol of happiness, depicted as a miraculously joyful place in the Odyssey. ${ }^{172}$

The use of the image is clearly ironic, as the most optimistic supporters of the unionist mission are portrayed as if they had imagined Bryennios and the two other ambassadors going to such a delightful place as the garden of the mythological king, while in fact they were heading to the Kingdom of Cyprus, facing a difficult ecclesiastical challenge. This ironic phrase, combined with the expression 'bright hopes', suggests to the reader that the union council in 1406, supported by Patriarch Matthaios I, was essentially a futile attempt, without any hope for advancing the cause of Orthodoxy.

Providing an explanation for the other image proves to be a slightly more complicated issue. The text points to the existence of an Ancient Greek mythological story in which the emanations of Aphrodite (Ourania) proved their destructive capabilities in the island of Cyprus, but it remains unidentified yet.

However, the equation of these emanations with the Latin rheum upon their similar destructive qualities is most interesting. Rheum in its biological meaning inhibits clear sight, while rheum in the abstract meaning, obviously used by Chortasmenos, inhibits sight in the abstract meaning: understanding. In the strongly religious context of the source, it can be interpreted as a claim that Catholic dogmas, through the adherence to them, prevent the understanding of religious truth, which leads to eternal damnation, to ultimate horror in Christian theology.

Later in his epistle, Chortasmenos makes another important statement. As he says, to tell it plainly, [Bryennios and his fellow ambassadors] showed it with [their] act, that their [teachings] are not hypocrisy and knavery [of the Orthodox], but are entirely the contrary, they honour nothing else more than the precision of the dogmas, even if the deceitful Latins strike them through. ${ }^{173}$

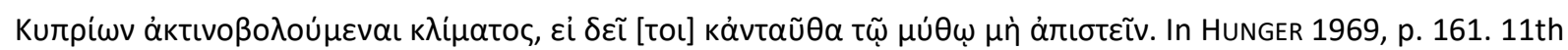
letter

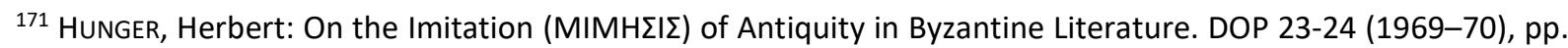
17-38, pp. 25-26.

172 Od. $\eta 112 \mathrm{ff}$.

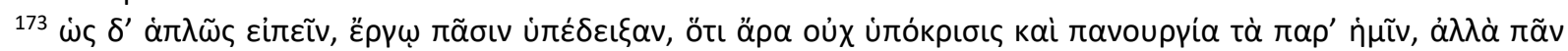

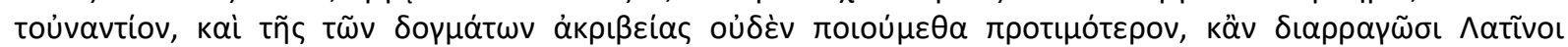

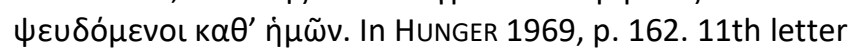


This single sentence formulates a ring of charges against the Latins. First of all, the use of the epithet 'deceitful' for the Latins and the statement that Bryennios and the two other ambassadors proved that the Orthodox teachings are not hypocrisy and knavery and the Orthodox honour nothing more than the precision of their dogmas suggest that the Catholics accuse the Orthodox with the corruption of their dogmas, besides their habits being hypocrisy and knavery, although these accusations are presented as obviously wrong, casting serious doubt on the honesty of the Latins.

Moreover, they are once again depicted as extremely violent, and their aggression is implicitly supposed to have an agenda: to coerce the Orthodox into accepting the charges brought up against them and 'correct' their behaviour. This 'correction' would logically mean the fullest acceptance of the Catholic teachings, claimed to be the 'true' ones by their adherents, but evidently not accepted as such by Chortasmenos.

Differences between Byzantines and Latins are multiple in the text of Chortasmenos. First of all, there is an extremely strong religious boundary separating the two groups: the Orthodox are presented as believers in Christian religious 'truth', while Latin teachings are condemned for preventing the understanding of this truth to such an extent that it eventually condemns their adherents to Hell.

Orthodox Byzantines are also depicted as evidently devoid of the hypocrisy, knavery and corruption that the Catholic Latins attribute to them, suggesting that the Latins are liars, creating another boundary between them. Finally, Latins are charged with keeping the Byzantines in Cyprus subjugated, upholding an oppressive system, while the Byzantines appear as the innocent victims of this system. It separates them not only in respect of access to power, but, especially accompanied by the other alleged failings of the Latins, implying a very different attitude towards power itself.

\section{II.3. Conclusion}

As it has been demonstrated above, the two main fields of violent conflict represented in the analysed letters are the perceived oppression by the Latins and the military engagement against them. First, the authors represent Latin rule as an actual 'tyranny' and ascribe to it various negative consequences, from the despair of the native population to the decline of cultural life and the persecution of innocent citizens. 
Secondly, in the case of Byzantine-Latin military conflict, the Byzantines are nearly always depicted as occupants of the moral high ground, their motivations are portrayed as 'right' and 'valid', while the motivations of the Latins as 'wrong' and 'invalid'. The only exception of it is a letter of Michael Choniates describing the fight between Leon Sgouros and the Latin crusaders, in which case the crusaders appear as the lesser of two evils. However, it is mainly motivated by the personal enmity felt by the archbishop against Sgouros, not by a tolerant attitude towards Westerners.

Regarding the portrayal of war between the Byzantines and the Latins, there is an observable tendency to present the Byzantines as victims for the audience. Most letters dealing with these military engagements depict the Latins as the initiators of conflicts, that is, the aggressors, while the Byzantines usually appear victimized as the reactive, defensive side, shifting the moral responsibility for violence to the Latins. Furthermore, if the Byzantine side appears as the initiator, there is always an explicit or implicit, for the contemporary readers, most convincing, justification for their behaviour, which is most usually the liberation of 'Roman' territories from Latin occupation, the heinous crimes committed by the Latins, or a potent combination of these two cases. 


\section{Closer Relationships}

A peculiar aspect of references made to the Latins in the analysed letters is the phenomenon of close relationships between the Byzantines and the Westerners, defined as friendships across the ethnocultural borders and even mixed families. Regarding the conflicts between the Byzantines and the Latins in the post-1204 era, such relationships were bound to attract criticism, as it is also presented in the letters.

\section{III.1. Latins in the Family}

A letter of Chomatenos explains the inheritance of those persons, who die without leaving a will or children, but their widow survives them. He highlights this issue through the example of a case from Corfu, in which certain Latins were heavily involved. Chomatenos describes how Marinos Kalopoulos from Corfu sought his legal aid.

He had a brother-in-law, Nikolakios Akronaras, who died without a will or any children, but left behind his young widow, Kale. Kale did not keep the mourning period, but married an "ethnic person", who was English. When the Englishman died, he did not leave any will or children, but Kale survived him. Soon she remarried with another man, a foreigner, who was the adjutant and deputy of the doux of Kerkyra. This man similarly died childless and untested, leaving her behind. In all cases, Kale kept the belongings of her late husbands. She did not remain a widow for long, as she married a fourth time and became the wife of a native Greek. ${ }^{174}$

From this man, she gave birth to a son, called Theodoros Salerinos. After the birth of Theodoros, Marinos felt it rightful to ask his inheritance from the belongings of his late brother-in-law from Kale, and her fourth husband was willing to compromise. However, both the fourth husband and Akronaras died before the case ended and Kale tried to install her son, Theodoros as the legal inheritor of all the wealth of his previous husbands.

It is important to note that while divorce in the Orthodox Church is permitted and can be even a necessity (for instance, in the case of adultery), the Church never encourages any

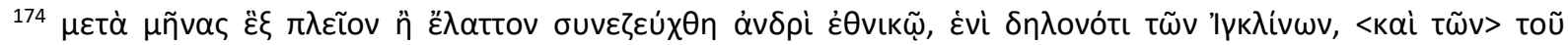

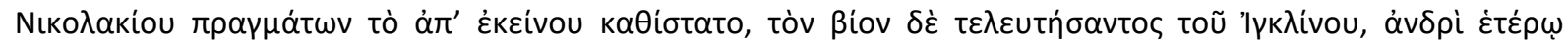

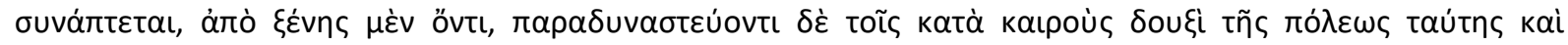

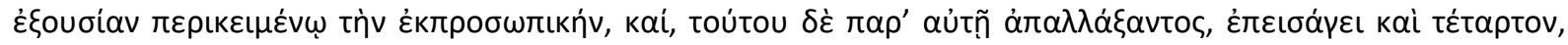

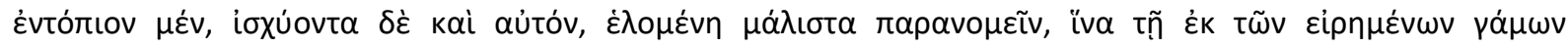

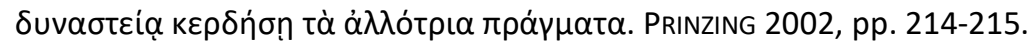


parties involved to remarry. Paul the Apostle in 1Cor. 7:39-40 states that a new marriage is allowed for widowers, but they receive no encouragement for practising their right for that, while Saint Ioannes Chrysostomos in his treatise, entitled To a Young Widow, admonishes the young lady addressed by his text to remain a widow instead of obeying human nature.

Furthermore, Saint Basileios the Great regarded a second marriage as an act punishable by one or even two years of excommunication, while, in his view, a third marriage called for three or four years of excommunication, and did not even deserve the name 'marriage', rather worthy to be called 'polygamy' or 'fornication'. Theodoros Stoudites in the $9^{\text {th }}$ century accepted that civil law allowed such marriages, but regards it forbidden to bless them in a church, branding the decisions of emperor Konstantinos V Kopronymos (741-775), who married for a second time and then for a third time.

From the same century, patriarch Nikephoros of Constantinople (806-815) stated that only the first marriage of a person may receive a 'crowning' by the Church. These sanctions against remarriage were only consequently practiced in the case of clerics, but a fourth marriage was unacceptable even in the case of laypeople. ${ }^{175}$

Another problematic factor is the fact that Kale kept all the belongings of all his deceased husbands, although she bore a child only to the last, fourth one. According to Byzantine canon law, a widow without children has a right to the wealth of her late husband only, if their marriage contract or the will of the late husband states it. In any other case, the natural heirs shall receive it. ${ }^{176}$ In the mirror of the aforementioned regulations, certain acts of Kale regarding her marriages and widowhoods were at least highly questionable, or even illegal. ${ }^{177}$

Another question that rises regarding the behaviour of the four-time widow was whether her second and third marriages were unions with Roman Catholics or not. According to canon law, an Orthodox could marry only another Orthodox, and, after 1204, branding the Catholics as 'heretics' became increasingly common among the Orthodox, ${ }^{178}$ creating a serious obstacle against any mixed marriages. The second husband is designated as an

\footnotetext{
175 MeYendoRfF, John: Christian Marriage in Byzantium: The Canonical and Liturgical Tradition. DOP 44 (1990), pp. 99-107, pp. 101-102.

176 SIMON, Dieter: Das Ehegüterrecht der Pira. Ein systematischer Versuch.Forschungen zur byzantinischen Rechtsgeschichte. Fontes minores VII, Löwenklau Gesellschaft e.V., Frankfurt a. Main, 1986, pp. 193-238, pp. 227-228.

177 For a very short commentary on this astonishing case, see PRINZING, Günter: Sozialgeschichte der Frau im Spiegel der Chomatenos-Akten. JÖB 32.2 (1982), pp. 453-462, p. 458.

178 NiCoL, Donald M.: Mixed Marriages in Byzantium in the Thirteenth Century. In DugMORE, C. W. - DugGAN, C. (Eds.): Studies in Church History I. Oxford - Edinburgh, 1964, pp. 160-172, p. 162.
} 
'Englishman' and an 'ethnic person', which, at first reading, suggests an English and therefore Roman Catholic man.

However, the possibility of conversion to Orthodoxy apart, members of the Orthodox Varangian community settled in the Byzantine Empire could be called 'English' since the late $11^{\text {th }}$ century, ${ }^{179}$ and, for instance, an imperial document of Michael VIII Palaiologos, from

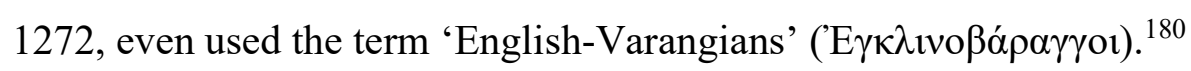

The third husband is described as a 'foreigner', and adjutant and deputy of the doux of the Kerkyra. The island came under the control of a Venetian pirate, Vetrano, a few years before the Fourth Crusade, but he seemed to disappear when the Crusaders reached the island, only to resurface as an independent ruler of the island shortly thereafter. In 1205, the Venetian fleet escorting Thomas Morosini, the new Latin patriarch of Constantinople, captured the island, but the inhabitants revolted against Venetian rule in the same year and Vetrano was reinstalled as ruler.

Nevertheless, Venice sent another invasion force in 1206, captured and fortified the island, and Vetrano was promptly executed. The island came under the rule of Venetian noble families in July 1207. However, the Venetians were ousted from Kerkyra soon again by Michael I Komnenos Doukas, ruler of Epiros, which can be dated to $1214 .^{181}$

As a consequence, Kale had the opportunity to marry Catholics. However, The Orthodox Church rejected Catholic-Orthodox mixed marriages after 1204, and Chomatenos, who is not hesitant to condemn her actions that contradicted the canon law, does not mention such a transgression. This circumstance makes it very unlikely that the second and third husband were Catholics. And so, the denominational boundary separating Byzantines and Catholics even in respect of marriage, although implicitly, is present in the source.

It is worth reflecting on the seemingly astonishing detail that Kale managed to marry four times, although Orthodox canon law explicitly forbade it. However, the social elite of contemporary Northern Greece entered into various types of illicit marriages as our sources testify. ${ }^{182}$

\footnotetext{
179 BLONDAL, Sigfus: The Varangians of Byzantium. Revised by Benedikz, S. Cambridge, University Press, 1978, p. 141.

${ }^{180}$ RHOBY, Andreas: Byzantine Greek Words in English Vocabulary? With an Appendix on Byzantine Terms for 'English'. In JuHÁsz, Erika (Ed.): Byzanz und das Abendland: Begegnungen zwischen Ost und West. Budapest, Eötvös-József-Collegium, 2013, pp. 53-69, p. 66.

181 NiCOL, Donald M.: The Despotate of Epiros. Oxford, Blackwell, 1957, pp. 17-19, 38.

${ }^{182}$ LAIOU, Angeliki: Mariage, amour et parenté à Byzance aux XI $-\mathrm{XIII}{ }^{\mathrm{e}}$ siècles. Travaux et Mémoires du Centre de Recherche d'Histoire et Civilisation de Byzance, Collège de France, Monographies 7. Paris, De Boccard, 1992, p. 54; LAIOU, Angeliki: Contribution à l'étude de l'institution familiale en Épire au XIIIIme siècle. Fontes Minores (Forschungen zur byzantinischen Rechtsgeschichte) VI (1984), pp. 275-323, p. 280.
} 


\section{III.2. A Greek Family among the Latins}

Another letter of Chomatenos, dated to the period between December 1222 and $1224,{ }^{183}$ describes the case of the freedom-fighter Chamaretos and his traitorous father-in-law and wife, who colluded with the enemy. According to Chomatenos, the paneutychestatos despotes, Ioannes Chamaretos sought the help of the ruler of Epiros, Theodore I Komnenos Doukas, as he wanted to divorce his wife, whom he left in the Peloponnesos, from where he had to escape. He had good reasons for both decisions. Chamaretos, an influential magnate of Lakonia, organised a revolt against Geoffrey I Villehardouin (1209-1228). Another magnate of the region, Georgios Daimonoioannes, until that time a supporter of Villehardouin, offered him an alliance against the Latins and betrothed his daughter to the uncle of Chamaretos, later even to Chamaretos himself.

The offers were accepted by the Chamaretos family to their ill fortune: neither did Daimonoiannes and his daughter cease to side with the Latins, nor did they provide military support. Instead, the daughter stole the most valuable belongings of her husband, sending them to the house of her father, and even betrayed the plans of Ioannes Chamaretos to Georgios Daimonoioannes, who then informed the Latins about them. Daimonoioannes even attempted to trap his son-in-law, calling him to the local Saint George Church to discuss the already emerging conflicts regarding their 'alliance', but Chamaretos managed to escape the trap and sought refuge in Epiros, achieving the favour of Theodore I and high social standing. ${ }^{184}$

After Theodore I listened to the petition, he proved supportive, but wanted to be sure about the situation, so he sent a delegate in the person of Manuel Stases to Daimonoioannes, in which he expressed his good will towards him, offering him an alliance against the Latins and asked him to send his daughter, the lawful wife of Chamaretos, to her husband. The delegate Stases, whose mission was carried out in secret, stayed in the house of Gabriel Larynx, another magnate in the Latin Empire, who maintaned quite decent relations with the Latins, so he was allowed to meet with Epirote subjects but was secretly on the side of the Romans. He suggested that Stases should not visit Daimonoioannes personally, as he would

\footnotetext{
183 Paul Magdalino dated the letter to 1222, while Günter Prinzing dated it to 1224 . For their respective argumentations, see MAgdalino, Paul: A Neglected Authority for the History of the Peloponnese in the Early Thirteenth Century: Demetrios Chomatenos, Archbishop of Bulgaria. BZ 70 (1977), pp. 316-323, p. 318. Henceforth MAGDALINO 1977; PRINZING 2002, p. 88.

184 PRINZING 2002, pp. 86-87.
} 
probably arrest him, but give the letter to a loyal priest instead, who could accomplish the mission without a grave danger. ${ }^{185}$

As the priest reported, he met Daimonoioannes in the aforementioned Saint George Church, ${ }^{186}$ who cursed the name of Theodore I Komnenos Doukas, claimed that Chamaretos had never had any wife when he had lived in the Peloponnesos but wanted one now and dismissed the frightened cleric. After Theodore I received the report and heard the testimony of the bishop of Pelagonia, who was also a refugee from the Peloponnesos and knew of the wickedness displayed by Daimonoioannes and his daughter toward Chamaretos, he referred the case to Chomatenos, who stated that marriage was beyond repair, so he canonically dissolved it. ${ }^{187}$

The treacherous behaviour attributed to Georgios Daimonoioannes by Chomatenos was not without parallels in real life, as, for instance, the Doxapatres family, which owned estates in the Skorta region, was regarded as a clan similarly duplicitous, feigning loyalty to Epiros, while seeking the friendship of the Latins. Furthermore, Ioannes Chamaretos, the sole magnate who resisted the Latins in the Peloponnesos after the fall of Leon Sgouros (1207/1208), may have been the son of Leon Chamaretos, who allied himself with Geoffrey I Villehardouin. ${ }^{188}$

If that identification is correct, the infamous past of the father is logically omitted from the text of Chomatenos, stressing the loyalty and bravery of Ioannes Chamaretos himself instead, forming the figure of a gallant, patriotic hero, who was deceived by his treacherous wife and father-in-law, but fortunately escaped from their hands, establishing himself in the bastion of Byzantine independence, Epiros.

This impression of Epiros being such a bastion is enhanced by the solution that Chomatenos quotes the letter of Theodoros I to Georgios Daimonoioannes in full, in which the Epirote ruler explains how his realm served as a safe haven for those, who escaped from the Peloponnesos and that the archbishop parallels Chamaretos with Odysseus, and Daimonoioannes with the cyclops, implicitly identifying the Saint George Church with the cave of Polyphemos and nicely placing the later mentioned escape of Chamaretos automatically into this epic context. ${ }^{189}$

\footnotetext{
185 PRINZING 2002, pp. 87-89.

186 Paul Magdalino identifies it with the Saint George Church in the citadel of Geraki, Lakonia. see MAGDALINO 1977, p. 322.

187 PRINZING 2002, pp. 89-90.

188 LOCK 2014, pp. 71-72.

189 PRINZING 2002, p. 87.
} 
One can see important differences between the Latins and the Byzantines in this text. Fighting against Western rule and for the re-establishment of Byzantine rule is presented as a laudable activity, which at least suggests that Byzantine rule over Byzantine territories is legitimate, while Latin rule over them is illegitimate.

But the Latins also appear using despicable persons as their agents to sabotage the fight against their rule and to set up a vile trap for Chamaretos, the leader of the anti-Latin resistance in the area. It implies that the Latin government of the Principality of Akhaia is not fastidious if it comes to eliminate its opponents, and openly ally itself with amoral individuals to achieve its objectives, pointing to rather low moral standards.

In this context, the cooperation of the Daimonoioannes family and the Latin elite of the Peloponnesos has a mutually degrimental effect on the perception of their respective morals in the eyes of the audience, the moral shortcomings of one side also harming the image of the other in terms of morality.

Meanwhile, the Epirot government shows helpfulness to the escaped leader of the resistance but also insists on investigating the involvement of Daimonoioannes and his daughter in the case, despite the details that suggest their collusion with the Latins. These acts frame the government of Theodoros I as moral and benevolent, in clear contrast to the Villehardouin regime.

\section{III.3. A Latin Becoming a Compatriot}

In another letter, written to Manuel Raoul, sent to Cyprus from Crete, in the summer of 1401, Manuel Kalekas states that he has sent his letter a short time earlier, using [the services of] a young Italian, who can be designated as their [of the Byzantines] fellow citizen. As nothing hinders that, neither the situation, nor the actual alliance, to call the [state] standing so close to their homeland [of the Byzantines]. And now he [Kalekas] will do exactly that, finding a bearer [for his letter] from the mentioned brothers, who was nigh at hand. ${ }^{190}$

This young Italian mentioned in the text was most probably a Genoese citizen, as this Italian state was the closest ally of Byzantium against the Ottoman Empire, as much in 1401 as in 1453. Besides, sending a letter with a Genoese subject to the island of Cyprus was also a

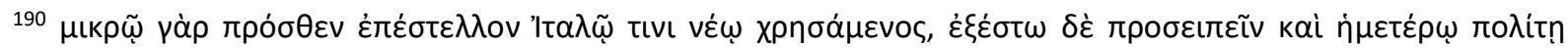

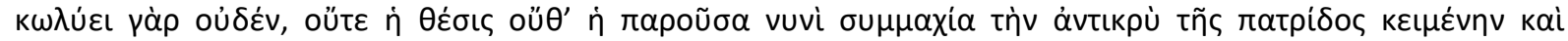

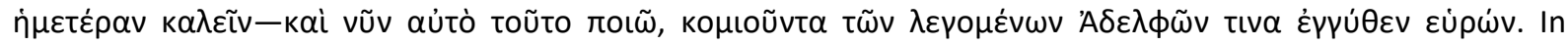
LOENERTZ, Raymond-Josef: Correspondance de Manuel Calecas. Epistolae. Città del Vaticano, Biblioteca Apostolica Vaticana, 1950. p. 254. 61st letter. Henceforth LOENERTZ 1950.
} 
question of practicality, as, following the successful war of the Italian city state against the Kingdom of Cyprus in 1373-1374, Genoa was the dominant commercial power in the island, its subjects enjoying a privileged status in the Lusignan possessions. ${ }^{191}$

Kalekas depicts an interesting image of this young man. The audience receives very few details about the letter-bearer, except that he is portrayed as a fellow citizen because of the alliance between Genoa and Byzantium, designated as a 'sibling' (just like all the other Genoese) and it is also suggested that he was willing to carry the letter of the author to Cyprus. The relationship of the two states is portrayed as being determined of certain qualities of their citizens, turning them into actual compatriots and even 'siblings' from a certain point of view, and the impression of the helpfulness displayed by the young Genoese underlines these claims.

These details also enhance the image of an exceptionally strong bound between the two states. Kalekas goes on to state that the close alliance between the two states allows their respective citizens to call both states their homelands, and by claiming that he is about to do that (even if not delivering on this promise in his letter), he stresses this argument even further. The emotionally upbeat representation similarly strengthens this impression.

The analysed remarks of Kalekas promote a very open-minded attitude towards the Genoese, depicting them as quasi-Byzantines. The origin of this compatriot status is claimed to be the alliance between Genoa and Byzantium, which is portrayed as capable of determining the relationships between their respective citizens essentially, turning them into fellow citizens of each other and citizens of both states. It is even suggested that the behaviour of Genoese and Byzantine individuals is influenced by the alliance, creating a good disposition towards the citizens of the other state.

However, the most important detail seems to be that Kalekas leaves the boundaries of this fictive community open. Genoese are depicted as ones who have become quasiByzantines by their solidarity and helpfulness towards Byzantium, which means that any other Latin community can join this group if it shows the same attitudes. As a result, an astonishingly inclusive ethnical identity is presented by the source, which was improbable to be shared by many contemporary Byzantines.

\footnotetext{
191 EPSTEIN, Steven A.: Genoa and the Genoese 958-1528. University of North Carolina Press, Chapel Hill \& London, 1996, pp. 236-237.
} 


\section{III.4. His Imperial Majesty and the Latin Petitioners}

In one of his letters (date and place unknown), written to Demetrios Chrysoloras, the emperor, Manuel Palaiologos vividly describes how occupied he is at the time of writing. As he says, it is impossible to excuse oneself from seeing those outside and those within and anyone troubled by some serious business. There is a Latin, there is a Persian, a citizen, a foreigner, not least of all a monk, each of them requesting a different thing, crying out that he would suffer injustice if his demand would not be fulfilled at once. ${ }^{192}$

These lines above provide some interesting details for the analysis. The depiction of tolerance towards such rudely demanding behaviour and absence of etiquette in the imperial court is fictitious, but it is part of the playful element in the representation given by the emperor, who, from the perspective of the addressee, presents an obvious caricature of a special aspect of his imperial duties, that is, listening to petitioners and deciding about their cases.

The crowd of petitioners arriving to have an audience with the emperor in hope of persuading him to assist them in solving their problems underlines a crucial function of the autokrator in Byzantine imperial ideology: being the supreme guardian of justice, upholding the rule of law, helping those whose rights had been violated and punishing criminal deeds. This function is intertwined with the duty of the emperor to embody philanthropy, to act benevolently towards every righteous person, and to care about their necessities as well as to reward them. ${ }^{193}$

Manuel stresses that it is impossible for him to neglect the petitioners and so underlines his own strict adherence to these two imperial duties, eventually representing himself in a very favourable light. The reference to Latins and Persians, that is, Westerners and Turks, appearing among those waiting for an audience, depicts the importance of the emperor as a ruler whose sway stretches far beyond the actual political boundaries of his own state, in accord with his universal role as Roman Emperor.

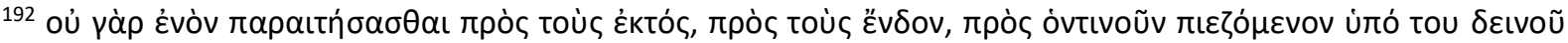

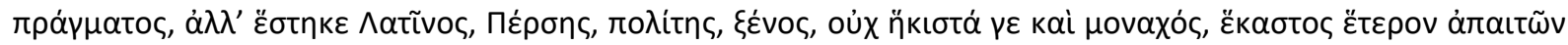

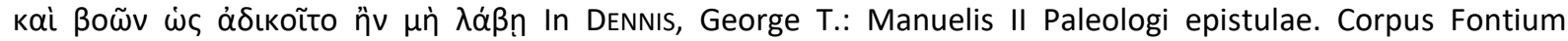
Historiae Byzantinae VIII = Dumbarton Oaks Texts IV) Washington D.C. 1977. p. 117. 44th letter. Henceforth DENNIS 1977.

${ }^{193}$ ANGELOV 2007, pp. 140-145.
} 
Besides, it also invokes the image of a just ruler, who, although he himself is Orthodox and 'Roman', does not refuse to provide impartial justice for 'non-Romans', even if these people happen to be Catholics or Muslims. The claims about the petitioners being shouting out disrespectfully seemingly without any consequence, is a comic exaggeration of the eminence of Manuel in practising these two imperial duties of him, stressing his virtues even further but serving a source of humour too.

\section{III.5. An Appeasing Embassy that Failed Remarkably}

In a letter addressed to Leon Bardales, Maximos Planoudes claims that earlier the Venetians did not receive them, who were carrying on an embassy [Palnoudes and Bardales] as such people who were beyond the fear of suffering anything that was possible or who would be rescued from that, but as [persons] who became subjected to so many terrible things that it is fearsome to describe them, if someone does not want to open up old wounds. ${ }^{194}$

These words suggest certain details about the Venetian reception of a Byzantine embassy in which Planoudes participated but are far from being exact. The letter of Planoudes suggests a rather rude and hostile behaviour by the Venetians against their embassy, but the details provided concretise only the harsh nature of this treatment.

However, this very embassy and its background are known relatively well from other sources. It happened in December 1296 in the Byzantine capital, that the head of the Venetian community in the city, the bailo, was murdered by Genoese citizens, who were probably motivated by the ongoing war between Genoa and Venice, into which Byzantium entered on the Genoese side that very year. The perpetrators fled to Genoa after their crime. In addition to this, Byzantium and Venice were in a war and Andronikos II has confiscated the entire property of the Venetian community in Constantinople earlier that year (circa 80.000 hyperpyra). Without doubt, all this led to the considerable deterioration of ByzantineVenetian relations.

To reduce the diplomatic harm caused by the assassination and the successful escape of the murderers, the emperor sent Maximos Planoudes and Leon Bardales, the addressee of the letter discussed, to Venice with the mission to explain that the Byzantine government did not have anything to do with the assassination. However, the results of the embassy proved to

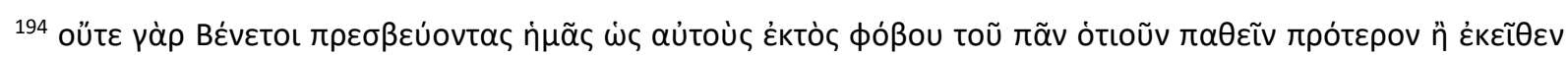

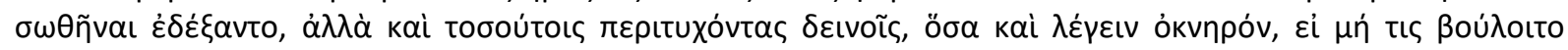

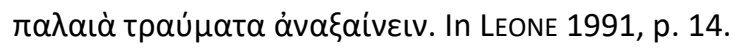


be disappointing. The Venetians openly condemned the perceived incompetence of Byzantine law enforcement and expected full compensation for the confiscated Venetian properties. In case their demands remained unfulfilled, they threatened with their refusal of renewing the 1285 bilateral treaty between the two states. ${ }^{195}$

Regarding these details, Planoudes probably refers to the threatened situation he and Bardanes felt in the Venetian capital. The text suggests fear of being attacked, by a mob or assassins, and not being protected, even allowing an interpretation that they were afraid of suffering atrocities by the Venetian authorities. The events that were not meant to be mentioned, if someone was not willing to cause emotional pain, were rather clearly the indignities experienced by the duo during their embassy, a reference that had to be far too obvious for Bardales.

\section{III.6. Conclusion}

Closer relationships with Latins receive different evaluations in the letters commenting on them. For instance, the Daimonoioannes family is presented as a dynasty of 'collaborants' to borrow an expression of modern political language, who cooperate with the Latin conquerors for material benefits, treacherously marrying a member of their family to a leader of an antiLatin resistance group just to make his movement fail, thus undermining the case of Byzantine restoration. The appeasing embassy led by Maximos Planoudes is claimed to be a source of fear and humiliation for its participants.

However, Manuel II Palaiologos treats his own benevolence towards the Latin petitioners in his court as natural and deserved by them, while Manuel Kalekas depicts a young Genoese contact of him as a quasi-Byzantine compatriot. The evaluations of establishing close relationships with the Latins present a wide spectrum, ranging from the utterly negative to the extremely positive.

\footnotetext{
${ }^{195}$ LAIOU, Angeliki E.: Constantinople and the Latins: The Foreign Policy of Andronicus II, 1282-1328. Cambridge, Mass., 1972, pp. 105-106.
} 


\section{The Morals of the Latins}

A recurring subject in Late Byzantine literature is debating on Latin morality, the spectrum ranging from the images of morally bankrupt people to depictions of decent fellow Christians. Epistolography is not an exception and the analysed letters serve with numerous examples for references to Latin morality.

\section{IV.1. Insatiability}

In a letter, written to Ioannikos, the kathegoumenos of the Saint Meletios Monastery, Michael Choniates, living already on the island of Keos, thanks the addressee for sending him food and drink with his last letter. As Chonaites claims, if anything edible or drinkable was left, avoiding the attention of the Italians passing by, who are beyond the mythological Harpies, who seized the food of people, that was sent by him [Ioannikios] to them [Choniates]. ${ }^{196}$

The monastery of Saint Meletios, founded by the eponymous saint himself in 1081, was near Eluetherai in Attica and remained in Orthodox control after the Crusader conquest, both of which facilitated the transportation of letters and food to the archbishop, residing in Keos. ${ }^{197}$ But the mentioning of food points to a common paraphernalia of Byzantine epistolography, that is, the attachment of a present to the letter. ${ }^{198}$ Another important factor of epistolography, the person of the letter-bearer, is similarly mentioned in the letter. Although the role of the bearer should not be overstressed, the written message contained by the letter

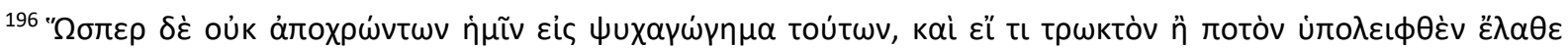

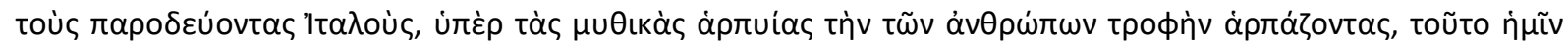

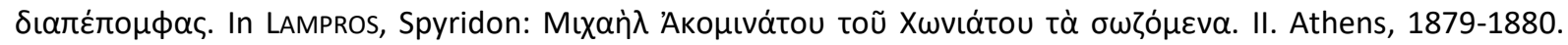
(Reprint Groeningen, 1968). p. 149. 93rd letter

197 KODER, Johannes: Hos. Meletios. In KODER, Johannes - HILD, Friedrich: Tabula Imperii Byzantini Bd. 1. Österreichische Akademie der Wissenschaften Philosophisch-Historische Klasse Denkschriften. Bd. 125. Wien, Österreichische Akademie der Wissenschaften, 1976, pp. 217-218.

198 GRÜNBART 2010A, pp. 159-169, esp. pp. 165-169 for presents sent by Choniates himself; MuLLETT, Margaret: Writing in Early Mediaeval Byzantium. In MCKITTERICK, Rosamond (Ed.): The Uses of Literacy in Early Mediaeval Europe. Cambridge, University Press, 1990, pp.156-185, pp.182-183. Henceforth MuLletT 1990; Bernard, Floris: 'Greet me with words': Gifts and Intellectual Friendships in Eleventh-century Byzantium. In GRÜNBART, Michael (Ed.): Geschenke erhalten die Freundschaft. Gabentausch und Netzwerkpflege im europäischen Mittelalter. Akten des internationalen Kolloquiums Münster, 19. - 20. November 2009 (= Byzantische Studien und Texte; Bd. 1), Münster / Hamburg / Berlin / London: LIT 2011, pp. 1-11.
} 
itself was most often accompanied by an oral message trusted to the carrier. ${ }^{199}$ This is very probable in that case, regarding the practice and the claim of Choniates, that the letter and the the monks produced a perfect image of Ioannikios. The identification of the letter with a substitution of the personal presence of its sender is also a topos of Byzantine epistolography. ${ }^{200}$

The classical erudition of the archbishop is proven by the reference to the mythological harpies. The harpies, originally the personifications of storms in Greek mythology, are already present in the Iliad, ${ }^{201}$ the Odyssey ${ }^{202}$ and the Theogony of Hesiod, ${ }^{203}$ but the most prominent story involving them is presented in the Argonautica ${ }^{204}$ of Apollonios of Rhodes. According to this myth, the blind Thracian seer and king, Phineus was tormented by these demonic creatures that always snatched away his food when he attempted to touch it. When Iason and the Argonauts arrived, Phineus offered them to predict the rest of their voyage if they chase away the harpies, which task was accomplished by the sons of Boreas. ${ }^{205}$ A little difference to the original myth is the claim that the malevolent creatures stole the food of many people instead of just the meals of Phineus.

As the Latins are presented as surpassing the harpies, these par excellence snatchers of anything edible and drinkable, taking away foods and drinks, it casts a very negative image of them. First of all, although the Latin activities mentioned by Choniates were merely collections of taxes, the parallel with the harpies invokes the image of rightless acquisition, and even robbery.

This impression is enhanced by the expression "passing by" ( $\pi \alpha \rho \circ \delta \varepsilon v ́ o v \tau \alpha \varsigma)$ which suggests an ad hoc raid. Furthermore, the statement that Ioannikios sends all of the food and drinks left by the Latins to subsidize Choniates supposes that their amount is scarce. Therefore, the Latins are framed both as robbers and extremely greedy persons simultaneously. The contrast between the selfless behaviour of the Byzantine and Orthodox Ioannikios, a representative of Byzantine values as a kathegoumenos, and that of the Latin

\footnotetext{
199 MULLETT 1990, pp. 181-182.

200 MULLETT 1981, pp. 79-80.

201 Il. 16. 149-51.

202 Od. 1. 241, 14. 371, 20. 66-78.

203 Hes. Theog. 267.

${ }^{204} \mathrm{Arg}$. 2. 234-434; a less detailed version of the story is presented in Hes. Fragm. 150-156 M-W.

205 Bremmer, Jan N.: Harpies. In Hornblower, Simon - SpaWforth, Anthony (Eds.): The Oxford Classical Dictionary. 3rd edition revised. Oxford, University Press, 2003, p. 667; Bremmer, Jan N.: Phineus. In HORNBLOWER, Simon - SPAWFORTH, Anthony (Eds.): The Oxford Classical Dictionary. 3rd edition revised. Oxford, University Press, 2003, p. 1172.
} 
tax-collectors, supposedly representatives of Latin values as trusted officials, could hardly be any more pronounced.

In his already mentioned letter to the patriarch of Constantinople, Michael IV Autoreianos, Michael Choniates echoes very similar accusations. Writing on behalf of the immigrant archon thematikos, Chalkoutzes, the archbishop pens that the archon saw the hopes to be nothing else but, as the proverb says, the dream-appearances of those already awake, as the 'tyrannical yoke' stood unmovably, as a Pythagorean man could say, like the axle of everything or like the tower of Zeus, and the things constantly pouring over with the not even for a little-while-covered jar of abundance were emptied out by the Latin insatiability.

He [Chalkoutzes] managed to escape the endless struggle of the Danaids through flight, rather escaping the aforementioned thing [the Latin insatiability], simply like the cave of other man-eaters, to never eat him after the last health-drinking of all things, in accord with the Cyclopic cup of friendship. ${ }^{206}$

The archbishop presents several Ancient Greek mythological, respectively philosophical allusions in this part of his letter. The jar of abundance may refer to the ancient idea of the cornucopia, which provided enough food for the - at least in the world of Greek comedies - legendarily voracious demigod hero, Herakles, ${ }^{207}$ so if the source refers to this element of the Greek mythological paraphernalia here, it portrays the Latins as ones surpassing the most ravenous Greek hero.

The Danaids, damned to bring water into a leaking jar for eternity in their futile job to fill it, suffering a divine judgement for the murder of their respective husbands, serve as a powerful image of an arduous and meaningless struggle. Furthermore, it mirrors the effect of the intriguing process of Roman interpretation of Greek mythology, as the story of this punishment of the Danaids in the Tartaros did not appear in their story until the Roman Imperial Era. ${ }^{208}$

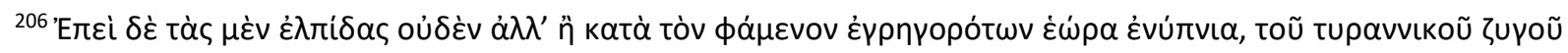

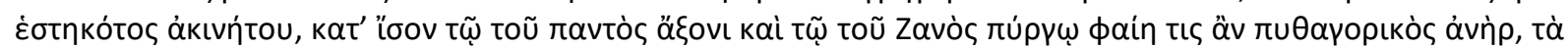

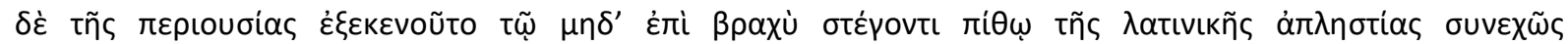

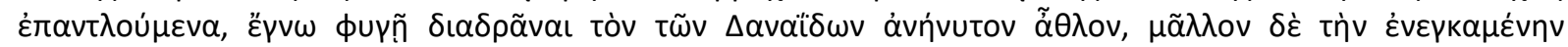

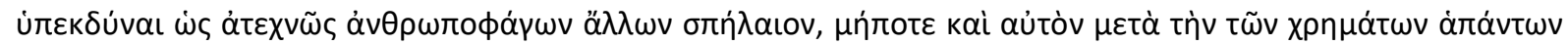

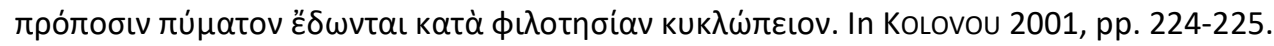

${ }^{207}$ Graf, Fritz: Herakles. In CANCIK, Hubert-SCHneIDER, Helmuth (Eds.): Der Neue Pauly. Enzyklopädie der Antike. Band 5. Metzler, Stuttgart-Weimar, 1998, pp. 387-394, p. 391.

208 Brown, Andrew L.: Danaus and the Danaids In Hornblower, Simon-SPAWFORTH, Anthony (Eds.): The Oxford Classical Dictionary. Third Revised Edition. Oxford, University Press, 2003, p. 428.
} 
The axle of the world and the tower of Zeus mentioned in the letter are one and the same concept in Pythagorean philosophy, to which ancient Pythagoreans also referred as the Central Fire. This concept was developed by the influential Pythagorean philosopher, Philolaos (BCE c. 470 - BCE c. 385), as an important element of his cosmological system. The Central Fire served as an axis of the cosmos in this system indeed, around which the Earth, a hypothesized counter-Earth and the other planets revolved. ${ }^{209}$

The most probable source of this reference is a part of a work by Aristotle, the On the $S k y$, in which he offers a falsification of the theory of the Central Fire, ${ }^{210}$ and which was definitely accessible in contemporary Byzantium. This reference demonstrates the very haute niveau paideiai of both archbishop Michael Choniates and the Patriarch, as it supposed knowledge of a very particular field of Ancient Greek philosophy from both the sender and the addressee. It can be regarded as a fine example of the phenomenon described by Michael Grünbart as paideia having a distinctive function as a social marker in the educated minority of Byzantine society, serving as a representation of social status. ${ }^{211}$

This part of the letter to Patriarch Autoreianos also envisions a noticeable difference between Chalkoutzes, presented as an exemplary Byzantine, and the Latins ruling Euripos in comparison to the previously discussed part of the letter. Latins have already been charged for their harsh tyranny, which has been suffered by Byzantines like Chalkoutzes, who had been used to a definitely more self-restrained style of governance.

Now, Latins are also condemned as people who are plagued by an extreme level of insatiability, always demanding more and more from those under their yoke. The local Byzantines found it difficult to tolerate it, not only because of its financial burden, but also supposedly because such behaviour was alien to their moral code. Chalkoutzes, designated as the most excellent of the local archontes, so theoretically the most eminent Byzantine on the

\footnotetext{
${ }^{209}$ On the role of the Central Fire in the cosmogony of Philolaus including its identification with the axle of the world and the throne of Zeus, see HuffMAN, Carl A.: Philolaus of Croton. Pythagorean and Presocratic. A Commentary on the Fragments and Testimonia with Interpretative Essays. Cambridge, University Press, 1993, pp. 202-215, pp. 397-398.

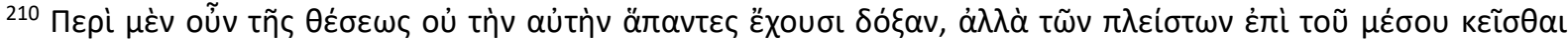

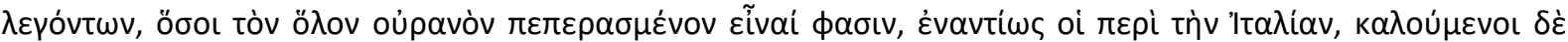

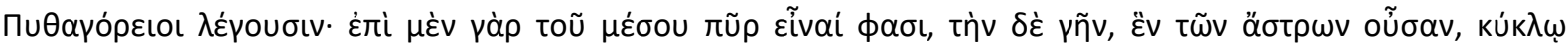

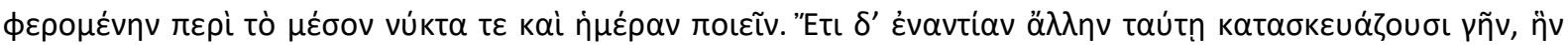

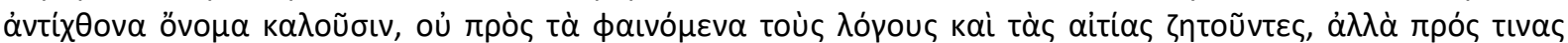

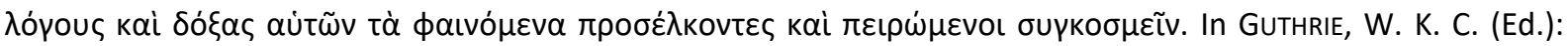
Aristotle: On the Heavens. 2.13.293b.1-16. Loeb Classical Library 338. Cambridge (Mass.) - London, Harvard University Press, 1939.

211 GrünBART, Michael: Paideia Connects: The Interaction Between Teachers and Pupils in Twelfth Century Byzantium. In SteCKEL, Sita - GAUL, Niels - GrünBART, Michael (Eds.): Networks of Learning. Perspectives on Scholars in Byzantine East and Latin West, c. 1000-1200, pp. 17-31, pp. 19-20.
} 
island, finally even left behind his native island, which is implied to be not a consequence of his finances becoming ruined, but his outrage felt for the behaviour of the Latins, marking a moral boundary.

The image of Latin insatiability also appears in a 'pair' of this letter, connected to the very same subject. In his above-mentioned lines, written to the archbishop of Crete, Nicholas, who escaped to Nikaia from his archdiocese, Michael Choniates describes Chalkoutzes as the pansebastos man who is the reason of addressing [Nicholas] with friendly writings and of speaking about things abroad, who comes from Euripos and is the best of the local archontes thematikoi and ktematikoi.

He [Chalkoutzes] paid a lot of things with money to the ones [Latins] tyrannising over Euripos. But there was no surfeit of the Latin insatiability, but, as the proverb says, as much was poured over them, he saw them to inflame so much more. Like the flame of fire quenches out in oil, finally he refused [to pay more], and chose to depart and exchange the aforementioned [land] with a foreign one. ${ }^{212}$

This version noticeably omits any references to classical culture, using a proverb and a parallel from everyday life, which may suggest that Michael Choniates did not suppose that his fellow archbishop would understand them, and recognised that he would potentially embarrass him with allusions that he would not understand, thus risking the success of his recommendation of Chalkoutzes to Nicholas.

Instead, he turned to a straightforward yet creative solution, representing the insatiability with the Latin triarchs and the Venetians with the proverbial fire, flaming the more intense the more water is poured upon it, while, exactly after that, the patience of Chalkoutzes appears as an everyday fire, finally quenched by oil, creating a thoughtprovoking dichotomy. This way the two letters, both being recommendations of Chalkoutzes to high-ranking clerics, provide an interesting instance for telling the same story with devices very different in their cultural niveau and complexity.

The letter to Archbishop Nicholas frames the problem of Latin insatiability suffered by the Byzantines of Euripos rather similarly to the letter addressed to Patriarch Autoreianos.

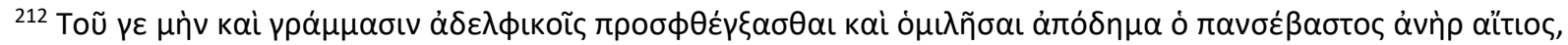

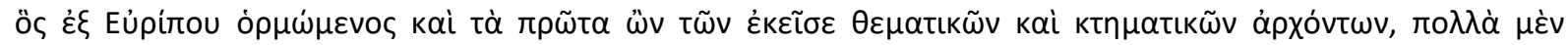

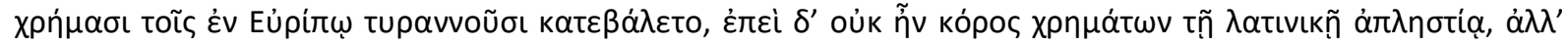

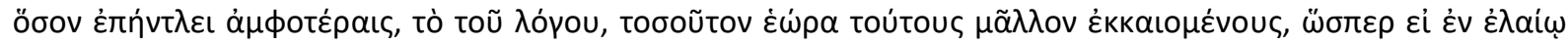

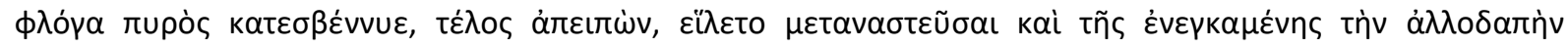
$\mu \varepsilon \tau \alpha \lambda \lambda \dot{\alpha} \xi \alpha \sigma \theta \alpha$ l. In Kolovou 2001, pp. 225-226.
} 
The local Latin community is presented to the archbishop of Crete as people who are never fulfilled with the money they extract from the Byzantines under their control, always demanding more.

Yet, it was not the financial burden of this exploitation that primarily motivated the escape of Chalkoutzes, but his moral objection to tolerate such behaviour. He appears as the most eminent member of the local Byzantine community, so it can be argued that the other members of the community might have had similar objections to Latin insatiability, even if they were not courageous enough to choose emigration. It all points to a general difference between the attitudes of the Byzantine and Latin citizens of Euripos, featuring the Byzantines as more modest people.

In another letter, addressed to Manuel Beriboes, Michael Choniates condemns the greed displayed by the Italians. He states that the barbarophon Italians turned the worship of Christ into the worship of gold, the Italians being comparable to the gold-digging ants, and he wishes if only the fate of Midas may reach the ungodly ones. ${ }^{213}$ According to Choniates, the greed of the Italians has reached such a degree that even Christianity was corrupted among their hands into a cult of gold, as he sarcastically remarks it with a Greek wordplay on the similar pronounciation of 'Christ' and 'gold', as ypsilon and iota were both pronounced as /i/ in contemporary Byzantine Greek. Furthermore, he uses a classical Greek allusion in his charge against Westerners, that is, the story of Herodotos on the gold-digging ants in his Histories. $^{214}$

Such charges against those Christian groups, whose beliefs were branded erroneous or even heretic, were common from the early centuries of Christianity, and the Catholics started to count as definitely such a group in the Byzantine world after 1204. The main argument behind this practice of accusation was that the deviation of Judas Iscariot from Christian piety and his later betrayal of Christ were said to be rooted in his avarice, ${ }^{215}$ certain quotes from the Gospels serving as the most handful arguments for this claim. ${ }^{216}$

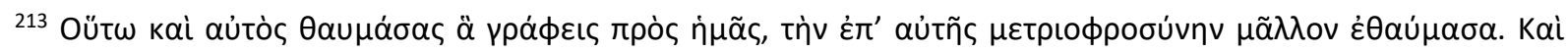

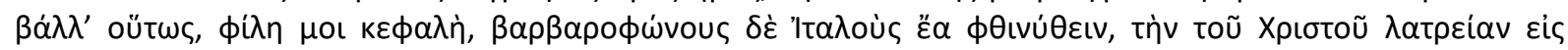

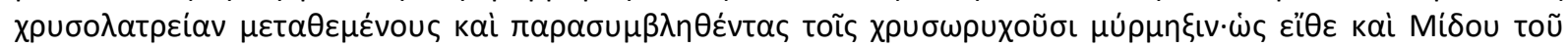

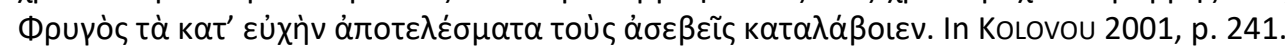

${ }^{214}$ Her. Hist III. cc. 102-105.

215 IRMSCHER, Johannes - WEYL, Carl Annamarie: Judas Iscariot. In KAZHDAN, Alexander - TALBOT, Alice-Mary (Eds.): The Oxford Dictionary of Byzantium. New York, Oxford, Oxford University Press, 1991, pp. 1077-1078, p. 1077.

216 In Matthew 26: 14-16, Judas Iscariot asks the authorities how they will reward him for his betrayal, while John 12: 1-6 states that he kept the purse of the apostles, regularly stealing from it.
} 
The wish for the Latins suffering the fate of Midas invokes the Greek mythological story about the legendary Phrygian king, who, for treating well Silenos, the lost mentor of Dionysos, received a wish from the god. He foolishly wished that anything he touches may turn into gold, soon discovering that it was rather a curse than a blessing, begging Dionysos to revoke his gift, which the god did.

After that, Midas hated luxury and became a companion of the god Pan in the wilderness, being present when Pan and Apollon competed for the title of the best musician. Only Midas questioned that Apollon performed better, and the angry god cursed him with having the ears of a donkey. As the king hid his transformed ears, only his barber knew the secret, whispering it into a hole in the ground, being unable not to utter the truth. Reeds grew above the hole, whispering the words of the barber, thus humiliating Midas.

It is not clear, which of these misfortunes are wished as punishments for the Latins by Choniates, but the gravity of any of them conveys an impression of harsh anger against the Westerners to the audience. Furthermore, the author drafts a very strong boundary between the Latins and the Byzantines, partly by disparaging the shortcomings of the Latins and partly by the omission of any comment on similar Byzantine sins. The Latin degradation of Christianity into a cult of gold could only be a spectacular phenomenon for the Byzantines, if their own Christian practice was markedly different, suggesting a strong difference between the religious life of the two groups.

In a letter dated to the $14^{\text {th }}$ century and addressed to Demetrios Maurianos in Thessalonike, Ioannes Chortasmenos depicts a more concrete aspect of Latin insatiability. After apprehending Maurianos, an aristocratic captain of the fleet, ${ }^{217}$ for not writing to him for such a long time, Chortasmenos hits a more lenient tone. He asks Maurianos, who prepares to set sail, with the words of Homer, to the wine-coloured sea, ${ }^{218}$ to get to know the habits of the people while seafaring between different islands, on each of them [islands], which were taken by the Latin greed, whether they [the local people] have not become entirely wild and have forgotten the Greek language. ${ }^{219}$

For the purpose of this chapter, the important detail is the claim that the islands were taken by the Latin greed. So, Chortasmenos portrays the main reason behind the Latin

\footnotetext{
${ }^{217}$ PLP 17414.

${ }^{218}$ Hom. II. E $771 ; \Psi 143$.

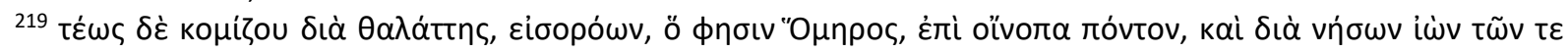

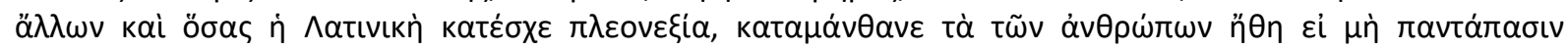

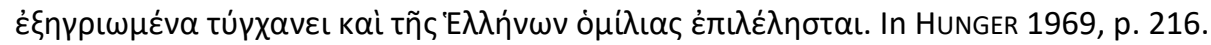


conquest of numerous Aegean islands as a powerful inner drive in the Latins for possessing more for the sake of owning it. The Westerners are depersonalized: it is not them but their greed that holds sway over a myriad of formerly Byzantine islands.

The local Byzantines are depicted as the hapless victims of the Latin greed and its consequences. Although it is invoked as a result of Latin rule that they unfortunately forgot the Greek language, but the Latin greed never infected them, just like there is no suggestion of them having been similarly greedy before the Latin conquest, which implies that they are different than the Latins in this respect.

\section{IV.2. Hybris}

Another recurring accusation against the Latins in the letters is their perceived hybris. An example of this is provided by a letter of Michael Choniates, written to his old friend, Ioannes Apokaukos, the archbishop of Naupaktos. After he praised Apokaukos for his letters and the care he showed for his nephew, Choniates claims that both Apokaukos and Euthymios Tornikes are fortunate men, as Apokaukos had never experienced the power of the Italian hybris, while Tornikes, being proud worthily, escaped [from the power of the Italian hybris], and now, living at the same place, they breath upon each other the sweetest thing, which is beyond the sweet oil of Aaron, just as the fragrance of Christ. ${ }^{220}$

Their perceived hybris had been a recurring accusation against the Latins during the centuries of Byzantium. The Western challenge against the supremacy of the Byzantine emperor and their questioning of the identification of the Byzantine Empire with the Roman one were seen as the pinnacles of this Latin trait. ${ }^{221}$ However, arrogance was a general characteristic of Latins in Byzantine ethnography, regularly presenting itself in all aspects of everyday life. ${ }^{222}$

As hybris was an integral and central part of the Byzantine stereotype of the Latins, it is not surprising that archbishop Choniates, experiencing Latin rule in the time of writing, voices this accusation against them. It is notable that hybris is connected to power and an

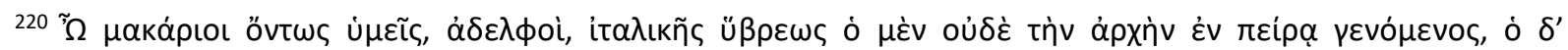

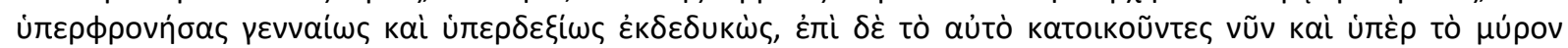

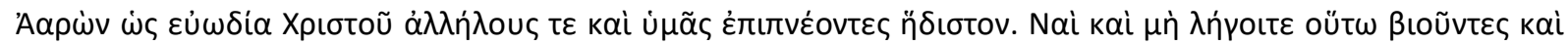

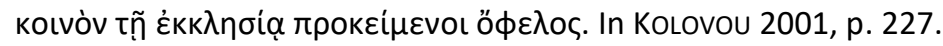

${ }^{221}$ HARRIS, Jonathan: Byzantium and the Crusades. Hambledon Continuum, New York, 2006 (First edition: 2003), pp. 22-23.

222 MESSIS, Charis: Lectures sexuées de l'altérité. Les Latins et identité romaine menacée pendant les derniers siècles des Byzance. JÖB 61 (2011), pp. 151-170, p. 154. Henceforth MESSIS 2011.
} 
implicit experience of suffering, avoided by Apokaukos, escaped by Tornikes, and, logically, still suffered by Choniates himself. The Byzantine stereotype of the Latins also included other 'masculine vices' besides their arrogance, that is, their striving for power, their very real power and capability of dominance, just like the victimisation of the Byzantines by them, ${ }^{223}$ causing these traits to fit well together for a contemporary Byzantine audience.

In turn, as the three friends are described regarding their suffering brought about by Latin hybris, or the fortunate evasion of it in the case of Apokaukos, it is suggested that they are not guilty of this moral fault. Moreover, they are not merely three friends, but also Byzantines, for some degree representatives of their community, despite all of their special qualities. This gives the impression that the Byzantines have definitely less problems with hybris than the Latins do, who seem to be plagued by this sin.

Drawing a parallel between the friendly discussions of Apokaukos and Tornikes and the unction of Aaron and the sweet odour of Christ is a creative step. The first refers to the unction with which Aaron, the younger brother of Moses was anointed to the priesthood, ${ }^{224}$ while the second is a reference to a concept appearing in Corinthians II of Paul the Apostle, in which he states that the faithful ones are the sweet aroma of Christ to God. ${ }^{225}$ These allusions should have been evident for Apokaukos, and they present a certain erudite, playful game with biblical references between the two highly educated archbishops.

A variant of this accusation, with a political charge even more pronounced, appears in the previously already mentioned letter of Michael Choniates, which was written to the emperor of Nikaia, Theodoros I Laskaris. As the archbishop states in his epistle, he prays for that the glorious emperor make not only Asia Minor impossible for the Italians to observe, but to free the Queen of Cities from their hybris too, chasing them away like mad dogs from their [of the Byzantines] holy enclosures around their Jerusalem, like the Jebusites of the old times

\footnotetext{
${ }^{223}$ MESSIS 2011, p. 163.

${ }^{224}$ NRSV Exodus 30: 30-33: „30 You shall anoint Aaron and his sons, and consecrate them, in order that they may serve me as priests. 31 You shall say to the Israelites, "This shall be my holy anointing oil throughout your generations. 32 It shall not be used in any ordinary anointing of the body, and you shall make no other like it in composition; it is holy, and it shall be holy to you. 33 Whoever compounds any like it or whoever puts any of it on an unqualified person shall be cut off from the people."

225 NRSV 2 Corinthians 2: 14-16: „14 But thanks be to God, who in Christ always leads us in triumphal procession, and through us spreads in every place the fragrance that comes from knowing him. 15 For we are the aroma of Christ to God among those who are being saved and among those who are perishing; 16 to the one a fragrance from death to death, to the other a fragrance from life to life. Who is sufficient for these things?"
} 
were by King David. ${ }^{226}$ The special significance of Constantinople in the Byzantine political ideology and its parallelisation with a new, Roman Jerusalem ${ }^{227}$ has been discussed earlier (p. 17), along with the portrayal of Byzantine-Latin conflict in this letter.

Regarding the above-mentioned Byzantine stereotypes of Latin arrogance and their political aspects, the reference is decipherable. The Latins are not the rightful rulers of Constantinople, their domination of the city and their imperial claims are tantamount to barbarian usurpation. The emperor, as the main representative and guardian of divine order in the world, ${ }^{228}$ violated in his own imperial rights, is the person most capable of restoring order and putting an end to the outrageous imperial façade of the Latins, who went beyond any previous atrocities with their conquest of Constantinople.

It is important to mention at this point, when Choniates depicts the emperor as avenging the gravamina committed against him and his empire by the Latins, that hybris retained not only its classical moral connotations in Byzantine erudite culture but it was also a legal term. Hybris was a wide legal category in Byzantine law, of any injury caused to another person by deeds or even by words, while wounding the other person that was considered severe hybris. The state did not automatically persecute acts defined under the term, but the injured person had to initiate the legal process. ${ }^{229}$

Remembering to this aspect of the word, the emperor as an agent of justice is depicted in two ways: first, as the guardian of divine order in the world, second, as an injured party taking action in his own case against the usurping Latins. Furthermore, the emperor is not only acting against the violation of his own rights, but the ones of his Byzantine subjects, as the actions of the Latins also caused serious grievances among them, and he is clearly aided by many of them in his mission.

Extending the category of victimhood to them too, it is suggested that the entire Byzantine community is an innocent victim of Latin hybris. The effect of being presented implicity as hapless victims is that they are very much devoid of this sin. Through this indirect way, once again, a boundary is presented between the Latins displaying serious hybris and the Byzantines avoiding this regrettable moral fault.

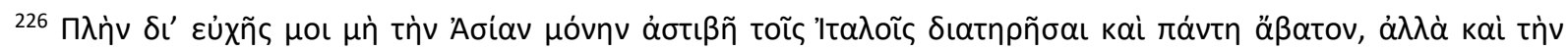

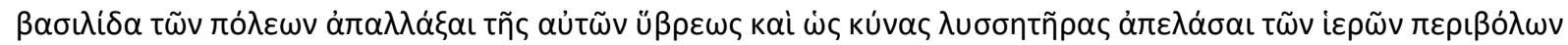

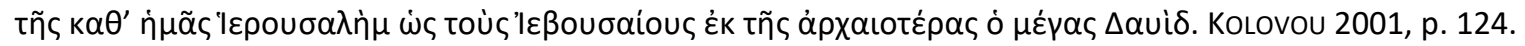

${ }^{227}$ AHRWEILER 1975, p. 13.

228 AHRWEILER 1975, pp. 138-139.

229 BuRgmanN, Ludwig: Hybris. In KAZHDAN, Alexander - TALBOT, Alice-Mary (Eds.): The Oxford Dictionary of Byzantium, New York-Oxford, Oxford University Press, 1991, p. 959. Henceforth BuRGMANN 1991.
} 
Another letter by archbishop Choniates, similarly written to Theodoros I Laskaris, has also been mentioned earlier (pp. 16-17) as one of the three recommendation letters written for the sake of arkhon Chalkoutzes and serves with an example of the Latins being condemned for their hybris. The metropolitan praises Chalkoutzes, who is from Euripos in the island of Euboia and a 'Latin-hater man', first because who else would be friendlier towards the Roman state.

Then, he explains that the arkhon, still being unable to bear the hybris of Latin tyranny, renounced all his belongings, children, homeland, relatives, chose to depart and risked being somewhere with the rulers of the Roman state, rather than staying in the tyrannised homeland and under the Latin hand. ${ }^{230}$

First of all, the theme of victimisation permeates the text, as the Latins appear as cruel oppressors in it. However, another subtext is present, in which political concepts play a key role. The most important characteristic of Latin tyranny in this context is its hybris and, as it has been demonstrated a few sentences above, Latin challenge against imperial legitimacy was understood as a special form of their inherent hybris, especially after 1204, as the former crusaders usurped the imperial title and ruled large, formerly Byzantine territories.

This interpretation of hybris in this argumentation of Choniates is supported by the following factors: he stresses the hatred of Chalkoutzes against the Latins, his loyalty to the Roman state, most naturally represented by Nikaia in this context, and that he left behind his children, relatives, homeland and wealth because he was unable to accept being under Latin rule, and wanted so fervently to live within the borders of the Roman state.

These elements merge into a powerful political statement, in which Nikaia is the sole legitimate successor of Byzantium, the Latins are arrogant usurpers who make a mockery of the great Roman heritage they claim to take over, while Chalkoutzes is a heroic figure, whose noble personality and suffering for the Empire should be rewarded by the emperor. It is also suggested that Chalkoutzes is an exemplary inhabitant of Euripos, an exquisite representative of his community.

His heroic resistance against the Latin hybris implies his general objection of such behaviour, and his role as representative gives the impression that a similar antipathy against

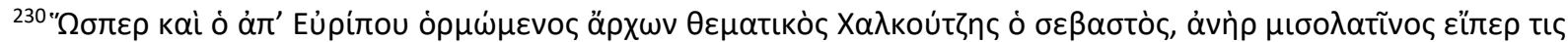

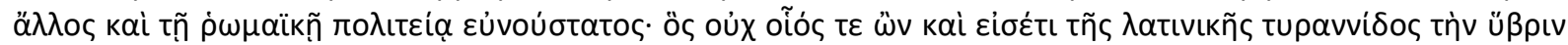

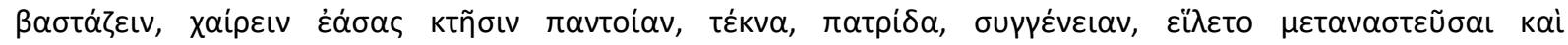

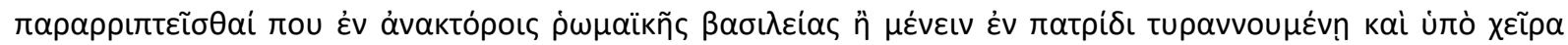

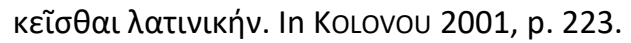


hybris exists among the Byzantines of Euripos. It presents a great difference between the arrogant Latins and the modest Byzantines.

Interestingly, the beginning of the very same epistle contains a rather similar accusation against Westerners. Choniates, after greeting the emperor, confesses that he is nearing to the end of his days, but still hopes and prays that he can see the Roman state being united under the rule of Theodore I Laskaris, who will crown his own God-crowned head with Davidian blessings, and will repay for the Latin 'madness' for what the Latins repaid to them [the Byzantines]. ${ }^{231}$

The message of the text is multi-faceted. The vision of Theodore I Laskaris reuniting the entire realm of his dethronized father-in-law, Alexios III, under his sceptre is a captatio benevolentiae rather than a realistic hope of archbishop Choniates. Although he probably desired it indeed, just like the barely concealed wish for revenge against the Westerners in the closure. The divine legitimation of the emperor is strongly stressed through the epithet "Godcrowned', strengthened further by the prospect of 'Davidian blessings'.

The invocation of the figure of David is especially important, as he was venerated, as being the author of the Psalms, the inventor of Jewish and Christian music, and as a great warrior king, who conquered Jerusalem from the Jebusites. What is more, David was a prefiguration of Christ, foreshadowing the victory of Christ over Satan with his victory over Goliath. ${ }^{232}$ As the emperor is clearly paralleled with David, Goliath serves as a parallel for the Latins, invoking the identification of Christ with the former and of Satan with the latter ones, which constitutes an extremely harsh judgement on the Latins.

Furthermore, the term 'madness' (árovoía) proves to be very interesting, as the principal meaning of aponoia is 'loss of all sense', which can be caused by fear, hope and despair, by madness and can be an equivalent of chaotic rebellion. ${ }^{233}$ Moreover, hybris in a

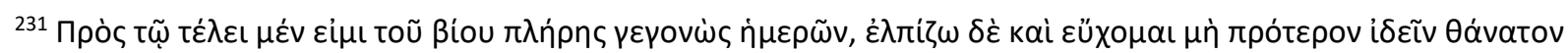

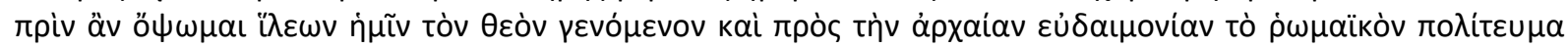

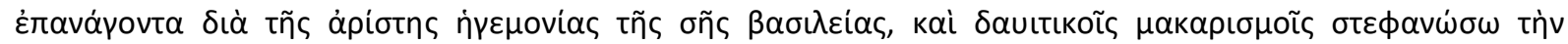

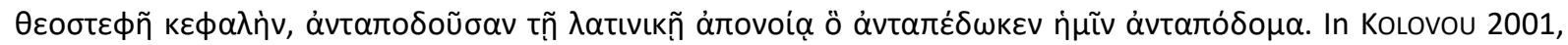
pp. 222-223.

232 LOWDEN, John H. - IRMSCHER, Johannes - CUTLER, Anthony: David In KAZHDAN, Alexander - TAlBot, Alice-Mary (Eds.): The Oxford Dictionary of Byzantium, New York-Oxford, Oxford University Press, 1991, pp. 588-599.

233 See áróvoı́a in Liddel, Henry George - Scott, Robert - Jones, Henry Stewart - McKenzie, Roderick (Eds.): Greek-English Lexicon. Ninth Edition with a Revised Supplement. Oxford, University Press, 1996, p. 211.
} 
Christian context has an aspect of rebellion against the divine order of the world, ${ }^{234}$ which evidently encompassed the Latin conquest of Constantinople for the Byzantines.

It makes Latin aponoia and Latin hybris closely related, and, regarding the context of this letter and the strong representative aim of Byzantine epistolography, it is possible that Choniates used the two expressions in the awareness of their semantic connection. If it is the case, the dichotomy of the Latins, plagued by their hybris, harming modest Byzantines is implicitly present even at the very beginning of the source.

However, this is not the sole example of the Latins being portrayed as arrogant people in a less-than-explicit way in the corpus of Michael Choniates. Writing to his nephew, also bearing the name Michael, the archbishop tells that he trusted a certain Kommolardos to be the abbot of Saint George monastery on the island of Makre. The metropolitan confesses to be afraid that the monastery in Makre will soon become deserted, suffering the fate of another Saint George monastery, located in the Kerameikos district of Athens.

As if that [monastery], being under the leadership of the honourable Loukas, who was respected even by the Latins, did not escape falling into ruin, how could the one in Makre [escape this fate], governed by the apprentices of Loukas? Because there is no apprentice who surpasses his master. There is no doubt that otherwise the monastery of Saint George in Makre would become a metokhion of the one in the Kerameikos, as that one [the one in Kerameikos] clearly came into complete ruin. ${ }^{235}$

The description provided by the metropolitan is highly pessimistic and worrisome. As he, in a rather authoritarian mindset, denies that any apprentice could surpass its master, the monastery in Makre under the governance of the apprentices of abbot Loukas, who failed to protect his monastery in the Kerameikos from coming into ruin, would suffer a fate even worse, unless a new abbot would arrive in the person of Kommolardos.

The depiction of this fate, alleged to be even worse, is very interesting, as it is portrayed as the monastery of Makre becoming a metokhion of the monastery in the Kerameikos. As a metokhion was a monastic community which did not qualify for the rank of

\footnotetext{
${ }^{234}$ FISHER, Nick R. E.: Hubris. In HORNBlOWER, Simon - SPAWFORTH, Anthony (Eds.): The Oxford Classical Dictionary. 3rd edition revised. Oxford, University Press, 2003, pp. 732-733, p. 732.

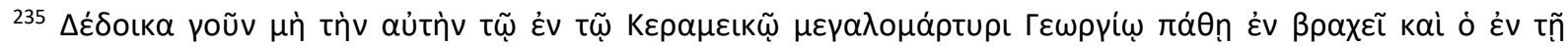

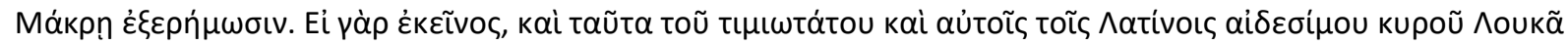

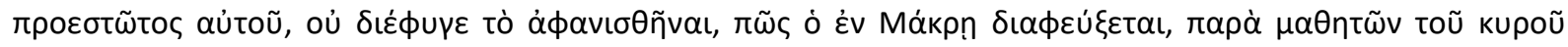

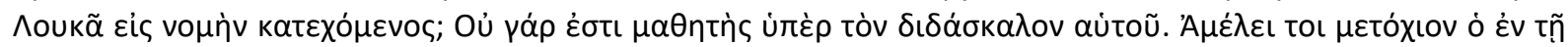

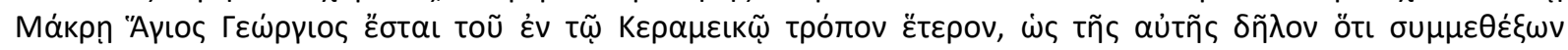
$\pi \alpha v \tau \varepsilon \lambda$ õৎ $\dot{\xi} \xi \varepsilon \rho \eta \omega \dot{\sigma} \sigma \varepsilon \omega \varsigma$. In Kolovou 2001, p. 193.
} 
a monastery, instead, it is controlled by the abbot of one, and often has no more than one or two permanent residents, ${ }^{236}$ this image envisions a deplorable future for the monastery of Saint George in Makre, without the aid of Kommolardos, chosen wisely by Choniates himself.

It is rather curious to see how Choniates utilizes the Latins in his discourse. According to him, Loukas, the unfortunate abbot of Saint George in the Kerameikos, was an honourable person and even the Latins respected him. This portrayal may be flattering for the memory of Loukas but has much less positive to say about the Latins. The statement implicitly suggests that whether the Westerners do not give due respect for venerable Orthodox religious authorities, but Loukas proved so honourable that he commanded respect even among them, or worse, they are disrespectful with most people in general, but the abbot managed to conciliate their approval.

In either of these cases, their underlying arrogance would be the clearest reason for this behaviour, presenting an appalling image of the new rulers of Attica. In turn, the late Loukas is suggested to be a remarkable abbot, as he managed to earn the respect of even these arrogant people. His apprentices at Makre are, unfortunately, not expected to be so charismatic to have such special effect on the Latins, standing much closer to the average Byzantine than their master did.

However, Choniates is concerned about them having the talent which would be needed to uphold the monastic community of Makre under the adverse Latin regime, but no piety, which gives the impression that the audience should view them as very moral persons. In addition to this, their proximity to the average Byzantine in talent, implying them to be relatively average, gives the audience the perception to see them as close to the average Byzantines in other respects, including their moral qualities, thus making the Byzantine everymen look decently moral, which hardly allows them to display hybris. This effect creates an implicit, yet detectable contrast between the Latins and the Byzantines.

Certainly, the appointment of Kommolardos did not save the monastery of Makre from the decline envisioned by Michael Choniates: eventually it became a metokhion of Saint George in the Kerameikos. ${ }^{237}$

\footnotetext{
${ }^{236}$ TALBOT, Alice-Mary: Metochion In KAZHDAN, Alexander - TALBOT, Alice-Mary (Eds.): The Oxford Dictionary of Byzantium, New York-Oxford, Oxford University Press, 1991, pp. 1356-1357.

${ }^{237}$ KODER, Johannes: Makre. In KODER, Johannes - HILD, Friedrich: Tabula Imperii Byzantini Bd. 1. Österreichische Akademie der Wissenschaften Philosophisch-Historische Klasse Denkschriften. Bd. 125. Wien, Österreichische Akademie der Wissenschaften, 1976, p. 210.
} 
However, it is not only Choniates who echoes the accusation of Western arrogance. In his letter, addressed to the protosebastos and protobestiarios, warning to Genoese piracy on the Pontic waters, Patriarch Gregorios II Kyprios states that the Genoese commit many treacherous deeds against the expedition of the emperor, they display many arrogant and contemptuous deeds. ${ }^{238}$ The key term is once again hybris, which can refer to both their perceived arrogance and the harm caused by them, as it has been mentioned earlier, ${ }^{239}$ which is accompanied by the accusation of displaying contemptuous behaviour, strengthening the previous impression.

Moreover, their arrogant attitude toward the imperial expedition and so toward the emperor and the Byzantine state itself is accompanied by the charge of Genoese treachery against the imperial ships. Treachery is a relatively wide concept, but the earlier mentioned charges of piracy in the same letter makes it decipherable as attacks on the imperial expedition.

The presentation of the Genoese attackers as persons who show utter hybris toward the imperial merchant ships, resorting even to piracy, and through this behaviour, showing hybris toward the emperor and his realm, also clearly defines the Byzantine merchants and their crew as the innocent victims of the behaviour of the Genoese, definitely not guilty in hybris like their abusers. This pronounced victimhood establishes yet another boundary between the Genoese pirates, who are alleged to be extremely arrogant, and the Byzantine merchants and crew, who are implied to be modest people, who respect imperial authority.

In one of his letters, written shortly after the summer of 1351, from Constantinople, to Athanasios Lepentrenos, to Cyprus, Nikephoros Gregoras makes a complex and rather obscure point. Lepentrenos was on friendly terms with Gregoras but harboured anti-Latin sentiments, besides his probable anti-Palamite ones, ${ }^{240}$ which helps to decipher the words of Gregoras to a certain degree. Gregoras claims that Lepentrenos could tell him how he [Lepentrenos] bears the Italian pride and the indeed not-exceedingly-genuine nonsense of the tongue and the arrogant arrow-barbs of the things told about themselves [by the Latins] and he [Lepentrenos] would not lose his head very much. As they tell the truth much less than they

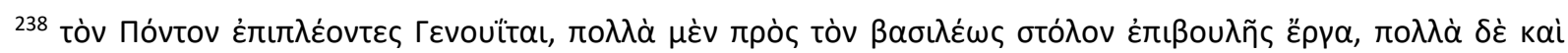

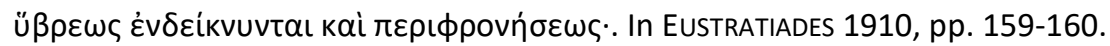

239 BURGMANN 1991, p. 959.

240 PLP 14743
} 
blether, they do not feel shame over the evidences from deeds, instead hybris gives birth to hybris and lie to lie. ${ }^{241}$

Gregoras charges the Italians, logically Latin intellectuals engaging in debates with Byzantine scholars, with an extreme level of arrogance, which is supported by his claim that the statements of the Italians about themselves are presented as a multitude of arrogant arrowbarbs, invoking that they are painful to be heard. And, while they rather blather instead of telling the truth, they do not display any shame when they are proved to be wrong, but, as it suggested, one arrogant act follows the other, and lies multiply.

The Latins, this time called Italians, are once again portrayed as an akme of human arrogance, unwilling to admit their own shortcomings even when they are uncovered without any doubt. This is in clear contrast to the Byzantines, represented by Gregoras and Lepentrenos, who are depicted as capable of identifying these Western moral faults, and do not seem to share them, but, without becoming infuriated by these haughty blathers, simply point out that the Latins are wrong.

\section{IV.3. Love of Strife}

Another moral failing attributed to the Latins surfaces in a letter, written by Manuel Kalekas to his friend, Maximos Chrysoberges, sent both to Florence and Crete, from Perai, Constantinople, in the spring of 1398, when Chrysoberges was studying theology in Florence. ${ }^{242}$ Kalekas comments on a 'characteristic' of the Latins, which, as he supposes, is known to Chrysoberges, that is, their love to strife. ${ }^{243}$

The reference most probably points to the second war conducted by Gian Galeazzo Visconti (1395-1402), the first duke of Milan, against the Republic of Florence, one of the main obstacles to his hegemonistic aims in Northern Italy. The war, which was fought from March 1397 to May 1398, demanded great sacrifices on both sides and the peace treaty that

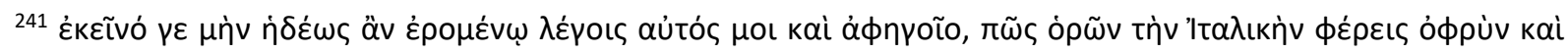

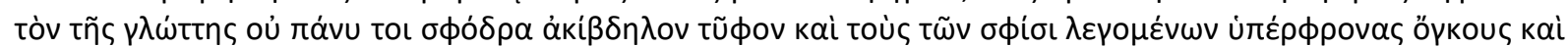

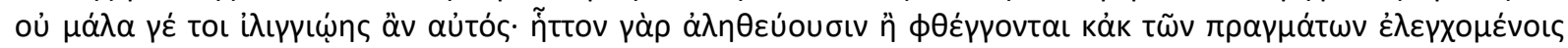

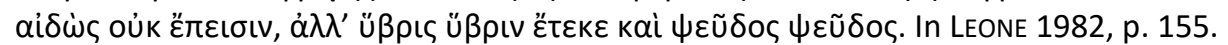

242 Delacroix-BESNIER, Claudine. Manuel Calécas et les Frères Chrysobergès, grecs et prêcheurs. In: Actes des congrès de la Société des historiens médiévistes de l'enseignement supérieur public, $32^{\mathrm{e}}$ congrès, Dunkerque, 2001. Les échanges culturels au Moyen Âge, pp. 151-164, p. 159.

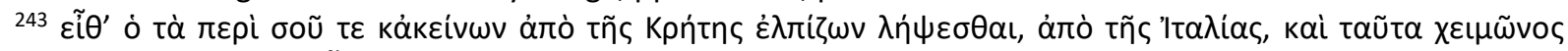

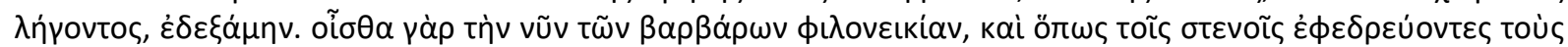

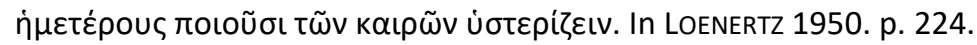


ended it, mediated by Venice, failed to solve the underlying conflict, promising nothing else but another clash in the foreseeable future. ${ }^{244}$

The explanation of the war between Milan and Florence expressed in the letter of Kalekas is a rather typical one, as it designates its main reason as the love of strife (philoneikia) among the 'barbarians'. This attitude that presented the Latins as inherently impetuous and eager to settle differences through violence was common in the Palaiologan era, continuing earlier stereotypes on Western 'barbarians' and providing a compensation for the military balance that shifted more and more in favour of the 'Franks'. ${ }^{245}$

However, attributing this trait to the Latins, and branding them as barbarians also establishes a position of confident Byzantine moral superiority, which supposes that the love of strife is not at all characteristic of the Byzantines, supposing a striking difference between the two ethnic communities.

\section{IV.4. Sexual Violence}

Nevertheless, the range of accusations disparaging Latin morality does not end with the claim of philoneikia. A very curious accusation is made against the Latins in a letter of Michael Choniates, addressed to his old friend and former hypomnematographos, then chartophylax, Georgios Bardanes. As Choniates asks Bardanes about the reason why he stayed in occupied Athens, the letter must have been written before Bardanes became the bishop of Grevena in $1218 .^{246}$

Choniates tells the story of Ioannes Syrinos, who became Christian (therefore, he must have been Jewish or Moslem previously) and wanted to marry the daughter of a certain Nyktopas, but Nyktopas protested against the marriage vehemently, although Syrinos was a righteous man and his daughter was willing. Furthermore, times were hard, not helping families with daughters, and Bardanes personally supported the young man.

As Choniates comments on the problem in a sarcastic, yet still worried way, people tell that the daughter of Nyktopas has shown importunate and uncompounded bad manners against her father. But it is also possible that her father shouted at her daughter, wandered during the night and did not listen to the marriage proposal, just as if he was hard of hearing

\footnotetext{
244 NAJEMY, John M.: A History of Florence, 1200-1575. Malden, Massachussets, Wiley-Blackwell, 2008 (1st edition), pp. 193-194.

245 KALDELLIS 2013, p. 176.

${ }^{246}$ NICOL 1957, p. 83.
} 
or deaf. But, if [Nyktopas] had an ear to hear, he could have heard how the Latins violate girls under the show of marriage. ${ }^{247}$

This charge against the Latins is definitely serious and raises questions. Nyktopas rejected the marriage proposal of Syrinos, most probably because the suitor was not a Christian in his earlier life, and Nyktopas harboured stereotypes against (former) nonChristians in general, or against (former) Jews or Moslems. However, with his behaviour, he endangered his daughter to become a victim of Westerners, who, according to Choniates, committed sexual violence against girls behind a cold-hearted façade of marriage.

However, an explanation much more plausible can be derived from the circumstances of the conquerors. The army of the Fourth Crusade logically consisted of men, and many of them did not have a wife with them or at home. These Latins had two opportunities after establishing their existence in the Latin Empire: marrying a woman from abroad, which would have been complicated and expensive beyond the resources of the average Latin in Romania, or marrying a local woman. The latter solution was far easier, cheaper and could serve as a means of creating ties with the native population and entrenching the new elite through blood relationships. However, it was not favoured by the noble strata of Latin society, who preferred Western wives, unlike sergeants and other not knightly groups, who very often accepted their limitations and intermarried with local Greeks. ${ }^{248}$

The interpretation of Choniates is definitely biased against these attempts, probably because such marriages involved the children being raised as Roman Catholics, and usually also the conversion of the originally Orthodox wife, which the archbishop could most probably not tolerate. It may be a consequence of his own attitudes that he presents such relationships as violence, himself being abhorred by the option that certain families and their daughters entered mixed marriages with consent.

The accusation that Latins violate young Byzantine women while pretending to marry them is claimed to be a real danger, and the praise of the convert Ioannes Syrinos as a possible husband for the daughter of Nyktopas are rather important details of the source. Even if he was a Jew or a Moslem earlier, Syrinos is a pious Orthodox now, wanting a lawful marriage and willing to join the local Byzantine community, in a clear contrast with the Latins, who are Christian, but in an 'erroneous' way, and do not show any real willingness to join the

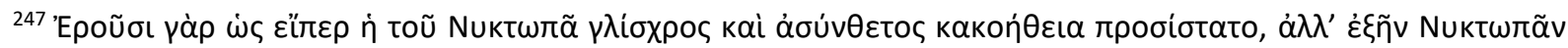

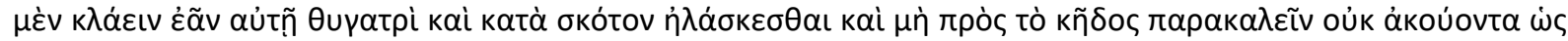

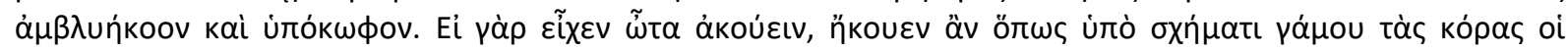

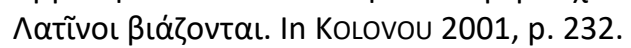

248 Lock, Peter: The Franks in the Aegean. 1204-1500. New York, Longman, 1995, pp. 290-292.
} 
communities they rule over, only pretend it to make sexual violence against Byzantine women easier.

Therefore, the audience is confronted with three serious moral differences. Implicitly, the dichotomy of 'correct' Orthodoxy leading to morally righteous behaviour and 'incorrect' Catholicism leading to depravity is present in the background. Explicitly, there is the contrast between the aim to lawfully marry a woman and the aim to violate her under the pretext of a marriage, and the chasm between the willingness to join the community and the intent to merely exploit it feigning an attempt to fit in.

The negative aspects of these qualities are embodied by the local Latin conquerors, while the positive ones are represented by Syrinos, already treated as a representative of the Byzantines by Choniates, generalising his attributes to his entire new community, Orthodoxy of these being evident. In this way, three moral boundaries are suggested by the author, featuring the Byzantines as definitely more ethical in all of these three respects.

\section{IV.5. Deceitfulness}

Another charge is Western deceitfulness that appears in the already mentioned letter of Patriarch Gregorios II commenting on Genoese piracy, in which he also voices his opinion on Genoese attitudes towards given word and friendship. After stating that he could hardly believe what the merchant Symeon told him about the Genoese pirate attack he survived in the Black Sea, the patriarch states that his addressee, the protosebastos and protobestiarios, Theodoros Mouzalon, should not doubt the reality of the story. As this tribe, of the Genoese, is evidently not to be trusted in regard of friendship and is otherwise disdainful and malicious. And it was neither of any use ever for the one who obtained them [the Genoese] as acquaintances, nor did they appear as persons behoving favours to anyone, as they delivered bitterness for favours. ${ }^{249}$

The Genoese are explicitly accused of regarding friendship as a façade that merely serves to further their own agenda, but does not entail on them any obligation. This personality trait, besides being a general characteristic of the Genoese, seems to show a strong tie with their disdain towards others, which is a manifestation of their hybris.

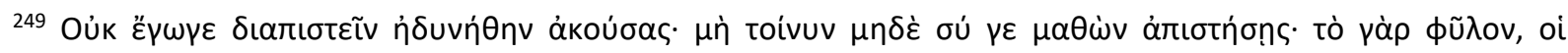

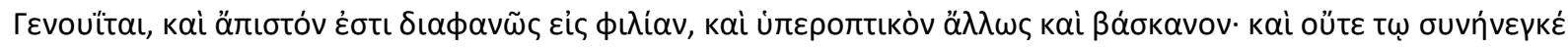

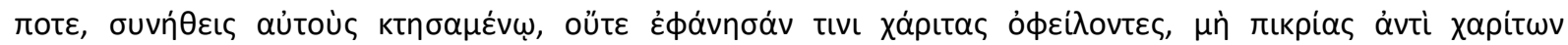

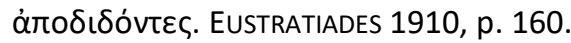


In the eyes of Gregorios II this is the reason why they proved to be worthless allies for everyone who was in league with them and did not seem to deserve any benevolence to anyone because they repaid favour with harm. A question logically derived from this is why the Byzantine Empire is allied to such people, so the letter implicitly suggests rethinking this alliance of the two states by the Byzantine government, showing a not very hidden political message in this part of the source.

It is worth mentioning that conflicts of interest between Byzantine and Genoese citizens were not unilateral aggressions by Genoese against Byzantines, unlike the patriarch presents the problem, but the sources also mirror atrocities committed by the Byzantines against the Genoese. For instance, the Genoese commune of Thessalonike addressed a letter of complaints to the imperial government in 1294, only five years after the end of the pontificate of Gregorios II, in which abuses against Genoese citizens committed by certain Byzantine officials of Thessalonike were presented among the major grievances of the Genoese community. ${ }^{250}$ However, all these incidents combined together did not qualify as a reason for the respective governments of the two states to severe the alliance between them.

\section{IV.6. Concoction of 'Poisons'}

In a letter written to Barlaam Kalabrios, Gregorios Akindynos criticised the addressee, part of which criticism was related to the Latins. First, he stated, he [Barlaam] seemed to him to have risen very high as a result of his great Italian embassy. ${ }^{251}$ Later on, Akindynos mentioned the possibility that maybe he himself had drunk a potion of forgetfulness and [therefore] did forget his own earlier behaviour towards Barlaam, [but] it seemed to him that he [Barlaam] suffered that [forgetfulness] from Italian poisons, because he [Barlaam] accused him [Akindynos] of not talking to him. ${ }^{252}$

The mentioned embassy can be dated to 1339. Andronikos III (1328-1341) sent Barlaam early that year to Robert the Wise of Sicily (1309-1343), Philip VI of France (1328-1350) and Benedict XII (1334-1342), with a mission of appealing for military aid against the

\footnotetext{
250 BALARD, Michel: The Genoese in the Aegean (1204-1566), Mediterranean Historical Review, 4:1 (1989), pp. 158-174, p. 160.

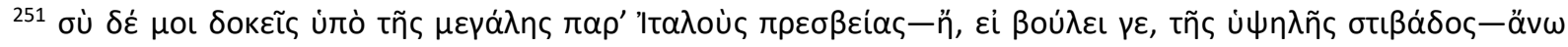

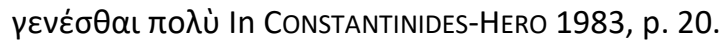

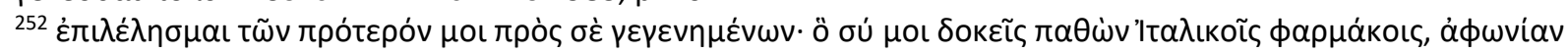

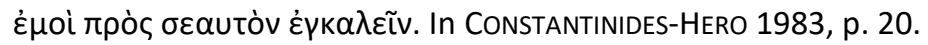


advancing Ottomans. Unfortunately, in spite of the relatively high hopes about these talks on the Byzantine side, they failed to secure any military aid for the Empire. ${ }^{253}$

The remarks of Akindynos are of a very friendly tone. First, the author praises Barlaam for the respect enjoyed by him as a result of his Western embassy (although, at the end, it failed to achieve its main goal), calling it an 'Italian' one. Then, he offers a humorous excuse for the scarcity of his communication with Barlaam, alleged by the addressee, logically in a recent letter to Akindynos. With playful irony, he ponders on that he may suffer the consequences of drinking a potion causing amnesia, and, therefore, not remembering his own negligence towards communicating with his correspondent, just to swiftly cast it aside to propose that it may be Barlaam, who suffers from such a condition, as he complained for Akindnyos not communicating with him (logically in the form of letters).

While this statement suggests that Barlaam had no reason to complain about the scarcity of letters sent to him by Akindynos, still he does it in an elegantly witty way, an especially interesting aspect of it is the creative utilisation of Westerners in its imagery. The claim about the enhanced status of Barlaam due to his embassy to the West merely used the ethnonym 'Italian' to determine the direction of the embassy (with questionable precisity). But the humorous excuse of Akindynos suggests that Barlaam has forgotten about Akindynos writing to him because of the effect of certain Italian poisons.

The author invoked the image of a potion causing forgetfulness and his suffering its detrimental effect, which concept he parallels with Barlaam suffering from Italian poisons of the same effect, so the poisons should be understood as physical ones and not abstract ones, that is, 'wrong' and 'harmful' ideas. As poison closely bound with the concepts of danger and dastardliness (characterised by underhandedness or treachery), and there is a definite ethnic marker attached to it, the joke also invokes rather unflattering images regarding Italians or, in a wider meaning, Westerners.

More precisely, even if playfully, Italians are conveyed as people concocting potent poisons, which are even capable of inducing amnesia, and some of them poisoning Barlaam with such a chemical agent. It ties the Italians with the concepts of grave danger and underhanded dealings with their targets. A moral division is conveyed between those turning to such vile deeds (the Italians) and those supposedly being above of committing them (the Byzantines), even if it unfolds in a mere joke, in a tone which is definitely not serious.

\footnotetext{
253 BosCH, Ursula Victoria: Kaiser Andronikos III. Versuch einer Darstellung der byzantinischen Geschichte in den Jahren 1321-1341. Verlag Adolf M. Hakkert, Amsterdam, 1965, pp. 139-145.
} 


\section{IV.7. Suspiciousness}

In a letter, addressed to the kathegoumenos of the Kaisariane monastery, Michael Choniates bitterly voices his fear that the addressee may think, just like some of the Latins and the Romans, that he [Choniates] earned a lot of money while he was metropolitan of Athens, and he and his companions lead a luxurious life on the island of Keos. ${ }^{254}$

These rumours can be connected to certain circumstances the conquerors met in the occupied Byzantine territories. Numerous bishoprics and archbishoprics existed in the conquered Byzantine territories and they were relatively poor in comparison with the Catholic sees of Western Europe. Therefore, most Latin hopes of acquiring great wealth through taking over the Orthodox dioceses and archdioceses were in vain, and, in many cases, these sees failed to provide the expected sources for their Catholic holders. It eventually led to a tendency of unification of bishoprics and archbishoprics by the Latins as a solution for the latter problem. ${ }^{255}$

However, among the first reactions to the disappointing conditions of the Byzantine churches, accusations about the Orthodox clergy hiding the wealth they had accumulated from their sees was probably a common one, denying the possibility that the hoped material goods did not exist at all, providing a psychologically more comforting explanation. As the letter can be dated to $1210,{ }^{256}$ it was a product of this early period of Latin rule, when suspicions of hidden wealth could be still very much alive among the conquerors.

The statement of Choniates that certain 'Romans' shared these Latin views can be explained that impoverished provincial Byzantines had their own motivations to believe that their clergy, enjoying a standard of living definitely higher than them, had accumulated considerable wealth through their ecclesiastical offices. Implicitly, these charges can be connected to a much more common charge against the Latins in contemporary Byzantine sources, including letters, that is, their insatiability and avarice, which has already been discussed in this chapter.

A circumstance worth mentioning is Michael Choniates' intention to draw nonethnical boundaries. Certain Latins in the Duchy of Athens are portrayed as suspicious

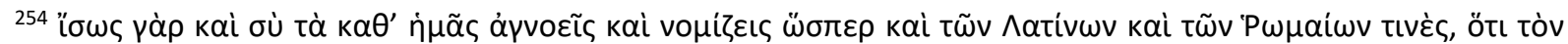

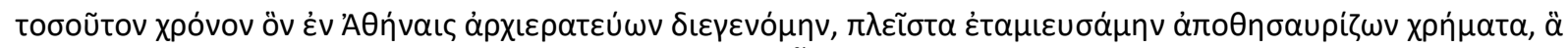

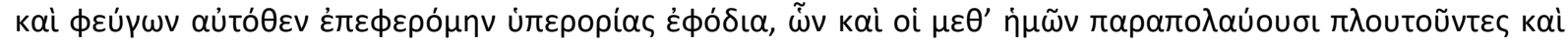

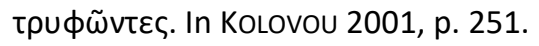

255 WolfF, Robert Lee: The Organization of the Latin Patriarchate of Constantinople, 1204-1261: Social and Administrative Consequences of the Latin Conquest. In Traditio VI (1948), pp. 33-60, pp. 44-47.

${ }^{256}$ Kolovou 2001, p. 139.
} 
persons, which is connected to their perceived greed. However, the same moral faults are attributed to certain local Byzantines, while there are both Latins and Byzantines in the peninsula, who are logically devoid of these shortcomings. In other words, a boundary is suggested within the Christian populace of Attica, but it is not drawn between the Latins and the Byzantines, but between those who are plagued by a baseless suspicion of hidden ecclesiastical wealth and those who are not subject to it, both groups encompassing Westerners and 'Romans' alike.

\section{IV.8. Conclusion}

The presentation of the morality of the Latins in the analysed letters shows a peculiar image. The range of the subjects involves the level of respect shown to the property and material well-being of the native population by its new rulers, the problem of treating the Greeks without haughtiness, the dilemma presented by the option of marriages being interethnic and interfaith at the very same time and the fairness of the system of justice under Latin rule, just as the trustworthiness of the Westerners. All these questions logically arise in a society when a part of it has to live under foreign rule while other parts of it experience a decline of their community's power and becoming dependent of the benevolence of another society, being less and less able to interact with said group as its equal.

Suspicion, fear, and frustration are necessarily present in such situations, and are greatly magnified if there is a history of hostilities with the dominant community, while perceived negative experiences in these fields are regular and numerous for the non-dominant group. As a consequence, exaggerated and one-sided stories about the moral faults displayed by the dominant group can express an actual belief in their shortcomings on the behalf of the non-dominant narrator, an attempt to articulate a sense of moral superiority as a compensation for the balance of power, which is understood as very unfavourable, and even a device of organising actions against the dominant group with the objective of changing the status quo.

Such attitudes are clearly present in the sources and serve as a viable explanation for their overwhelmingly negative (re)presentation of Latin morals, just like for the disparagement and condemnation they voice against Western moral shortcomings they accept as facts. 


\section{Culture}

Secular culture, with its incredibly various aspects, offers a very fertile ground for representations of another ethnocultural community at any historical era. That was also true for Byzantine depictions of Latins between 1204 and 1453, as it is proven by the numerous references made to Western culture in the analysed letters.

\section{V.1. Memories of Latin Roman Culture in Byzantium}

In a letter of Michael Choniates, addressed to Euthymios Tornikes, to Karystos, ${ }^{257}$ the Latins are connected to a special aspect of culture, poetry. Tornikes and his friends are praised for their capability of composing $i \alpha \mu \beta 1 \sigma \mu o i ́, \sigma i ́ \lambda \lambda o r$ and Italian $\varphi \alpha ́ \mu o v \sigma \alpha .^{258}$ These praises suggest that Tornikes and his circle were familiar with the genres of Ancient Greek and Latin literature, and could compose in them, even if their knowledge did not surpass that familiarity to a great extent, and it is not very probable that they understood Classical Latin.

'I $\alpha \mu \beta 1 \sigma \mu$ óv refers to the satirical genre of the í $\alpha \mu \beta$ os, tracing back its origins to Archaic Greek literature, its most consequent characteristic being its insulting voice. ${ }^{259} \sum \hat{i} \lambda \lambda$ ov can be identified with Classical $\sigma i ́ \lambda \lambda o \zeta$, which, according to the Greek literary tradition, was a genre established by the Pyrrhonist philosopher, Timon of Phleios (ca. 320 BC - ca. 230 BC), who composed a collection of them which was divided into three books, under the title $\Sigma i \lambda \lambda o r$, relying heavily on the tradition of the moralising diatribe cultivated by the Cynic school. ${ }^{260}$

Finally, $\varphi \alpha ́ \mu o v \sigma o v$, generally designating slanderous, libellous texts, ${ }^{261}$ in that case refers to the genre of $\varphi \alpha ́ \mu \omega \sigma \sigma \alpha$. Фá $\mu \omega \sigma \sigma \alpha$ has its roots in the Latin term 'carmina famosa',

\footnotetext{
${ }^{257}$ Karystos was a town on the southern coast of the island of Euboia. KODER, Johannes: Karystos. In KODER, Johannes - HILD, Friedrich: Tabula Imperii Byzantini Bd. 1. Österreichische Akademie der Wissenschaften Philosophisch-Historische Klasse Denkschriften. Bd. 125. Wien, Österreichische Akademie der Wissenschaften, 1976, pp. 183-184, p. 183.

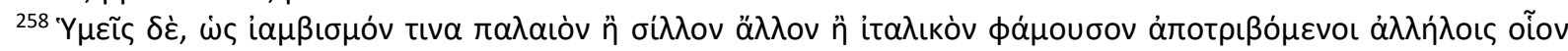

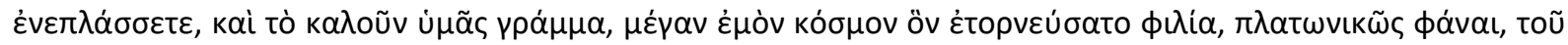

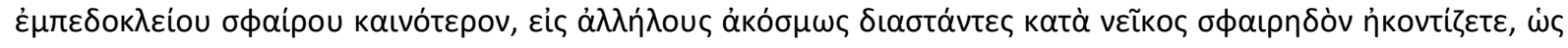

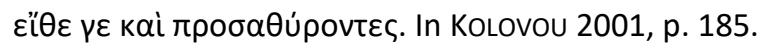

${ }^{259}$ WEST, Martin: lambus.In WEST, Martin: Studies in Greek Elegy and lambus. In DöRRIE, Heinrich - MoRAUX, Paul (Eds.): Untersuchungen zur antiken Literatur und Geschichte. Band 14. Berlin - New York, De Gruyter, 1974, pp. 22-39, p. 22.

260 BeTt, Richard, "Timon of Phlius", In ZALTA, Edward N. (Ed.), The Stanford Encyclopedia of Philosophy (Winter 2018 Edition), URL = <https://plato.stanford.edu/archives/win2018/entries/timon-phlius/>. Last accessed 5 November 2019.

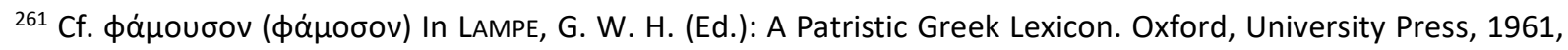
p. 1470.
} 
that is, 'infamous songs' also known as 'famosa libelli', which were satirical and offensive verses composed to criticise the person chosen as their subject, whose group ranged from private citizens to emperors. ${ }^{262}$ The Suda, the most important Byzantine lexicon, identified it as a satirical genre, ${ }^{263}$ and mentioned the case of the emperor Iovianus (363-364), who became the subject of vitriolous $\varphi \alpha ́ \mu \omega \sigma \sigma \alpha$, because he handed over the strategically important Mesopotamian city of Nisibis to the Sasanian Empire, causing a public outrage within the Roman state. ${ }^{264}$

Relying upon these facts, the use of the ethnonym 'Italian' could evoke the knowledge of Tornikes and other educated members of the audience about the Classical Latin origins of the genre of $\varphi \alpha \dot{\mu} \omega \sigma \sigma \alpha$, the close connection between this culture and Italy, and the relationship between the Latin-speaking inhabitants of Italy in Late Antiquity and its contemporary populace, which spoke various Italian dialects. Moreover, given the use of the terms 'Latin' and 'Italian' as synonyms for Westerners in $13^{\text {th }}$-century Byzantine culture, this ethnonym can even be interpreted as a designation of all Western Christians, tying all of them to the cultural heritage of Ancient Latin culture.

Whether the term refers to only Italians or Westerners in general, such a solution enhances the cultural standing of the group in question through tying it to a respected literary genre to one of these communities, both usually portrayed as culturally backward groups compared to the Byzantines in mainstream Byzantine culture and also in the epistolographic corpus of Choniates himself. Furthermore, it also establishes a connection between the Byzantines, regarding themselves as the Greek-speaking inheritors of the Ancient Latinspeaking Romans and the Italians/Westerners, who also appear as connected to the latter group.

Although Choniates makes these concessions, he still obviously sees great differences between the Byzantines and the 'Italians'. Even if both communities have their respective ties to the Ancient Romans, they are still understood as different ethnocultural groups and the Byzantine relationship to Ancient Rome is definitely much stronger, given the contexts of

262 AgOSTI, Gianfranco: Late Antique lambics and lambikè Idea. In CAVARZERE, Alberto - AloNI, Antonio BARCHIESI, Alessandro (Eds.): lambic Ideas. Essays on a Poetic Tradition from Archaic Greece to the Late Roman Empire. Lanham - Boulder - New York - Oxford, Rowman \& Littlefield Publishers, 2001, pp. 219-255, p. 240.

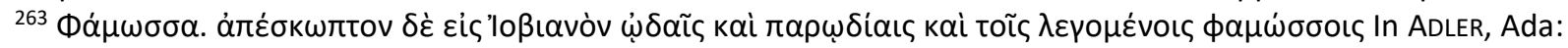
Suidae lexicon, 4 vols. [Lexicographi Graeci 1.1-1.4. Leipzig: Teubner, 1.1:1928; 1.2:1931; 1.3:1933; 1.4:1935]: 1.1:1-549; 1.2:1-740; 1.3:1-632; 1.4:1-854. Vol. 4. p. 696, Ф 64. Henceforth AdLER 1928-1935.

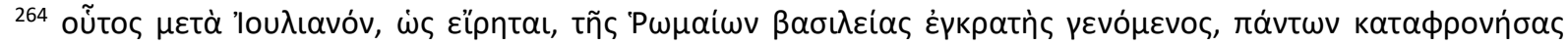

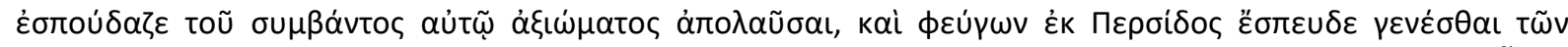

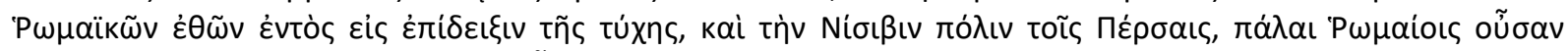

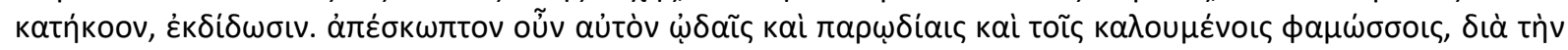

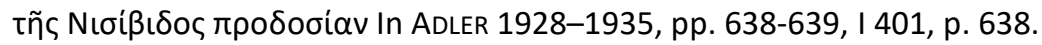


Byzantine elite culture and the letter corpus of Choniates. Similarly, the perceived gap in cultural niveau narrows down but it does not close, as it is supported by the same contexts and the fact that Choniates mentions two, definitely Ancient Greek genres before the $\varphi \alpha \dot{\mu} \mu \sigma \sigma \alpha$.

In another letter of him, Choniates describes an unclear monetary transaction between an unnamed Latin and a certain Peter the Monk, a person otherwise unknown. The letter was written to a grammatikos in Thebes and displays numerous wordplays on copper. Two details of this letter are of interest for this study. First, Choniates states that small copper coins are known as noummi by the Italians and as oboloi by the Atticans. ${ }^{265}$ Second, he states that the Latin taking part in the business gave the noummi to Peter the Monk for certain products. ${ }^{266}$

Choniates here displays his classical erudition once again. The reference to oboloi as a denomination made of copper in Attica describes the currency system of Classical and Hellenistic Athens, while the reference to noummoi in Italy has to mean the Italikos noummos, which became the smallest denomination of the Roman monetary system by the reforms of Diocletianus (284-305). ${ }^{267}$

Later, the noummos lost its role as an extant denomination, but the Greek language preserved its memory, as noummos leptos and simply noummos served as synonyms for small change in Byzantium. ${ }^{268}$ The unknown Latin person, who bought some products, most probably of low value, from Peter the Monk, just like the monk himself, seems to be of superficial interest for Choniates, their business serving merely as an à propos for the wordplays the archbishop wanted to show to the unnamed grammatikos.

However, the fact that small exchange copper coins were known as noummi in contemporary Byzantium and that Choniates states that the Italians use the very same name for them, also demonstrates a common point between Byzantine and Latin culture, regarding a peculiar financial aspect of them. It is even possible that the anonym grammatikos (suggesting an educated person) was aware of this circumstance and its historical roots, although it is far from being sure.

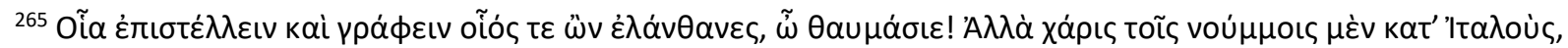

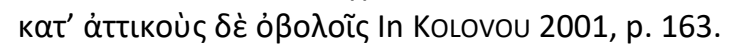

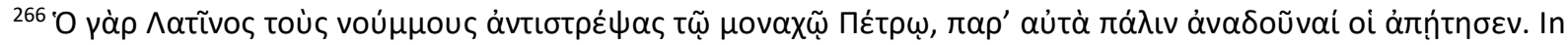
Kolovou 2001, p. 164.

${ }^{267}$ HeNDY, Michael F.: Studies in Byzantine Monetary Economy, c. 300-1450. Cambridge, University Press, 1985, p. 453. Henceforth HENDY 1985.

268 HeNDY 1985, p. 330.
} 


\section{V.2. A Taste Most Questionable? Latin Textiles Worn by Byzantine Citizens}

References to material culture are not limited to the field of coins in the sources. In a letter (date and place unknown), addressed to the protosebastos and protobestiarios, Theodoros Mouzalon, Patriarch Gregory II of Cyprus tells a story that only superficially involves the Latins world. Phrangopoulos, a former tax collector, after his wife had passed away, sold his landed property and began to practice a lavish lifestyle, including that he wore fine textiles made with much care by Italians. ${ }^{269}$

Unfortunately, he committed a horrible crime with eight associates, including four tzakones. ${ }^{270}$ They broke into the house of the megas sakellarios of Hagia Sophia, armed with swords, silenced his wife with force, then abducted and raped one of his daughters. Gregory II personally took part in the hunt after these criminals, being present at the arrest of some of them. The four tzakones remained at large, but the other culprits were arrested and Phrangopoulos was sentenced to be paraded on the streets of Constantinople, during which he was publicly shaved and humiliated in other ways, then was imprisoned.

Later, his relatives petitioned for his release claiming that he was dying, but the patriarch had doubts, so he asked a reliable doctor to judge the health of Phrangopoulos and help to decide if there was a real need for mercy. ${ }^{271}$ The prisoner was released upon the judgement of the doctor, and his later fate remains unknown. ${ }^{272}$

It is worth mentioning that the name Phrangopoulos itself points to Western origins. The Byzantines started to designate Western mercenaries with the name Phrangopouloi in the 11th century. The Phrangopoulos family was founded by such a mercenary and it achieved a relatively high status in Byzantium to the 13th century. ${ }^{273}$ The patriarch may have mentioned the circumstance of the criminal possessing expensive Italian garments not only because it demonstrated his vanity, underlining his moral corruption, reaching its summit in committing

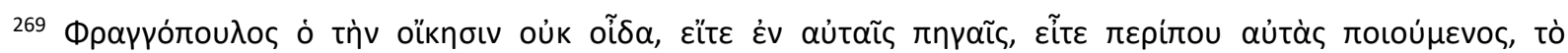

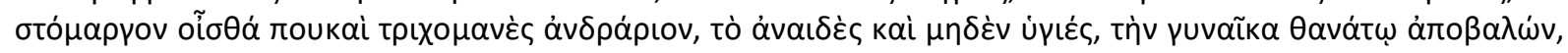

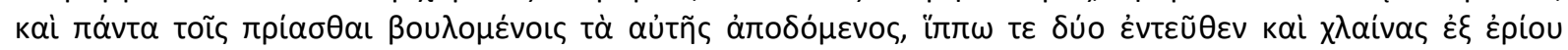

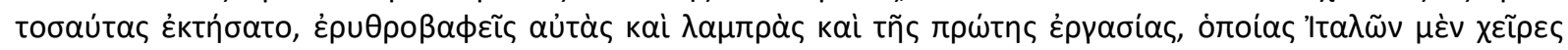

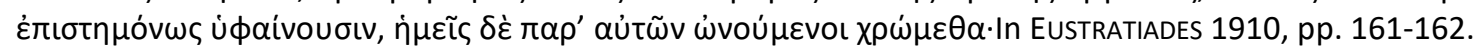

${ }^{270}$ For the application of the tzakones as a police force in Byzantium see CHARATZAS, St. C.: Les Tzakones. Berlin, 1976, p. 189.

271 LAIOU 1996, pp. 104-105.

272 PLP 30080.

273 NICOL, David: Symbiosis and Integration. Some Greco-Latin Families in Byzantium in the 11th to 13th Centuries. Byzantinische Forschungen VII (1979), pp. 113-135, pp. 114-116.
} 
sexual violence, but because of his family had evidently Western origins, possibly portraying him in an even more negative light.

The fact that he asked for a careful medical control of the allegedly fatally ill Phrangopoulos before anybody would release him, suggests distrust against the imprisoned man and his relatives, and makes the presence of antipathies believable, especially remembering his personal involvement in solving the case.

Regarding the Italians, the claim that the clothes of Phrangopoulos were made with a lot of care by them and the text designating them as important elements of the lavish lifestyle of their bearer, defines them as luxury products created with exquisite skills. Their producers, the Italians are excellent artisans as their ability to make them shows it, while the patriarch does not mention it if Byzantine tailors would have been able to sew garments of the same quality.

However, the circumstance that Phrangopoulos, portrayed as wealthy and very vain, used these clothes as parts of his self-representation, suggests that these Italian textiles were held in high esteem among the contemporary Constantinopolitan elite, lacking home-made parallels, or, if they had their Byzantine equivalents, the Latin products were more appreciated for an unknown reason. Combined with the claim about the skills required to their making, the former possibility seems to be more probable.

If this is the case, the Italians are not only supposed to be excellent artisans, but also as ones more adept in their trade than their Byzantine colleagues. The embarrassment for the difference in knowledge would make the lack of an explicit comparison understandable. But why does the patriarch even refer to the skills of the Latin tailors? A possible explanation is that through tying the fine Italian garments to the convicted criminal Phrangopoulos, and especially to one of his moral faults, vanity, the letter can imply that they are in fact similar to each other.

Phrangopoulos was haute niveau regarding his material goods, caring much about this aspect of life, but lowly in respect to his morals, neglecting them, and the Italians, closely connected to his failings by the text, may resemble him to a certain degree. It would establish a large difference between the Byzantines and the Italians in the field of generally understood morality. 


\section{V.3. The 'Unutterable Flesh': Unclean Food on Latin Tables}

In one of his letters, addressed to Euthymios Tornikes, Michael Choniates mentions how difficult it is to hunt bears in Attica, and when they are caught, they most often land on 'Latin tables' as gifts, serving as a most delicious meal for Westerners. ${ }^{274}$ These comments on Latins who appreciate bear meat fits into an important Byzantine tradition, the lists of the Latins errors, which regularly contain statements about the perceived 'unclean' dining habits of the Latins.

In these lists, a recurring accusation is that Latins consume the meat of bears and greatly err with that. As Kolbaba argues, relying on the theory of 'anomalous animals', developed by Mary Douglas in her book on the restrictions imposed by Judaism on food consumption, ${ }^{275}$ the Byzantine treatment of bears as unclean animals may be a consequence of them walking on four feet yet do not having any hoofs, unlike most animals with four feet. According to the theory of 'anomalous animals' proposed by Douglas, the human mind attempts to organise the world into categories, and certain animals that prove to be ambiguous in their categorisation for a culture, are often treated with suspicion and termed 'unclean' by said culture. ${ }^{276}$

Following this interpretation, the claim that Latins eat bears as a delicacy most probably wanted to demonstrate their 'wrong' dietary habits and their 'low' cultural niveau, showing them less civisled than their Byzantines subjects and serving as a comfort for the Byzantine readers of the letter for the social order of the Latin Empire, which was disadvantageous for their community. Implicitly, these remarks could also urge the reestablishment of the status quo ante, in which social status and level of culture could be imagined by contemporary Byzantines as having a stronger connection with each other than in the new social system, introduced by the conquerors.

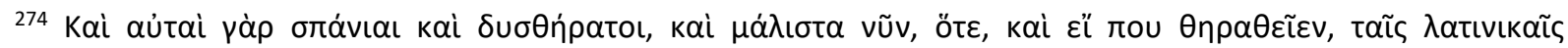

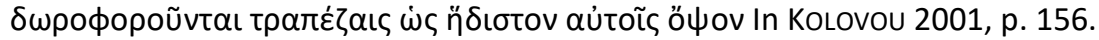

275 Douglas, Mary: Purity and Danger. An Analysis of Concepts of Pollution and Taboo. Abingdon-on-Thames, Routledge, 1966.

276 KOLBABA 2000, pp. 154-155.
} 


\section{V.4. No Latin should rule over any Roman ... for a Different Level of Culture?}

As Apokaukos states it in a letter to Theodore I Komnenos Doukas, he could give the opinion, if maybe he was asked, that it is not fitting for any Latin to hold Roman men as pronoia, even if [this person] would work for wages, even if [this person] would confess the dogmas. ${ }^{277}$ The context in which the expression pronoia appears in the sentence supports the supposition that in this case pronoia should be understood with its fiscal meaning. In its fiscal meaning, pronoia was officially a grant of certain tax revenues originated from designated properties and designated paroikos (dependent peasant) households, but, in practice, the holder of the pronoia was also entitled to some of the rents on the property. ${ }^{278}$ Furthermore, these grants provided rights over the local paroikoi, to such an extent that these grants where occasionally described as attributions of paroikoi. ${ }^{279}$

According to Apokaukos, it is not fitting if a Latin has such a grant over Roman (that is, Byzantine Greek) men (logically dependent peasants), which suggests a perceived hierarchy of ethnicities. As, in the system of pronoia, a pronoiar, whose status was higher than being just a free subject of the Empire, received rights over paroikoi, dependent peasants. Apokaukos implicitly claims that, in this perceived ethnic hierarchy, qualitative difference between the Byzantines and the Latins is so formidable that even a Byzantine paroikos should not be subordinated to a Latin whose status is logically higher than of a mere free imperial subject.

The metropolitan archbishop stresses that he upholds this judgement even if the Latin person involved serves for a wage, and even if this person confesses the (Orthodox) dogmas, which means that rewarding deeds for the Byzantine state and following Orthodoxy do not mean exemptions over this rule stated by him. These statements suggest the perceived qualitative difference between the Byzantines and the Latins to be even larger than it had been suggested by the beginning of the letter, while excluding heterodoxy as a potential source of this unequal status.

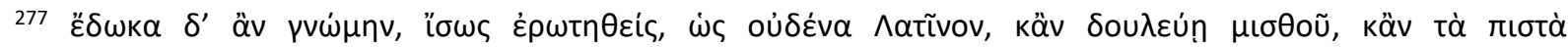

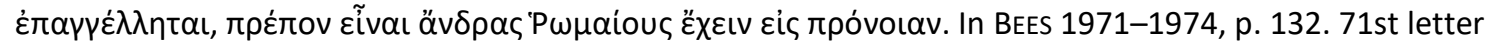

278 BARTUSIS, Mark C.: Pronoia In KAZHDAN, Alexander - TALBOT, Alice-Mary (Eds.): The Oxford Dictionary of Byzantium. New York, Oxford, Oxford University Press, 1991, pp. 1733-1734.

${ }^{279}$ ANGOLD, Michael: Church and Society in Byzantium under the Comneni, 1081-1261. Cambridge, University Press, 1995, p. 319.
} 
So, Apokaukos implicitly alleges that a qualitative difference exists between members of the Latin and 'Roman' (Byzantine) ethnic groups but does not precise the source of this perceived difference. It is possible that this lack of explanation is not by accident but is the consequence of the understanding of Apokaukos that the reasons of this unequal status should be evident for the addressee. Another possible explanation is that this omission of details originates from the intention to invoke certain ethnic stereotypes in the addressee with a bare reference to the perceived unequal standing of the Latins and the Byzantines, and stress their 'evident' nature by remaining silent about them.

In either case, the most a historian can do is making a conjecture relying on otherwise known historical information. Byzantine culture did not hold racist views of the Latins being inherently inferior to Byzantines, which excludes the possibility of such an approach by the author. The option that Apokaukos treated every Latin as a threat in the ethnic crisis caused by the Fourth Crusade and the Latin Empire, and his opposition to any Latin having control over even Byzantines of dependent peasant status was rooted solely in this circumstance, is hardly tenable regarding his other extant written attacks on Latins, which many times include ethnic stereotypes that serve as explanations of his rejective attitude.

A very probable reasoning for the perceived Latin inequality could be the religious difference, but the author claimed that his verdict is valid even if the Latin in question is an Orthodox believer. However, another deeply rooted Byzantine stereotype on Latins was their perceived cultural inferiority to Byzantine culture, and the archbishop does not exclude this justification in the source. This belief and the strained relations between the State of Epiros and the Catholic world under Theodoros I are the most probable arguments Apokaukos implicitly relies on in his qualification of the Latins and the Byzantines.

\section{V.5. 'A Return of the Vandals?' Uncivilised Latins Endangering Byzantine Culture}

In one of his letters, addressed to Theodoros, the metropolitan archbishop of Euripos $^{280}$, Michael Choniates mentions Italian barbarians, who acquired his library, but they

\footnotetext{
280 Theodore was one of the Orthodox bishops in Latin Greece who submitted themselves to Pope Innocent III. In 1208, he was still ejected from his see by Bérard, the Latin archbishop of Athens, who followed the friend of Theodore, Michael Choniates in this metropolitan see. But his loyalty to Innocent III caused the pope to order his reinstallation. COUREAS, Nicholas: The Latin and Greek Churches in Former Byzantine Lands under Latin Rule. In Tsougarakis, Nickiphorus - Lock, Peter (Eds.): A Companion to Latin Greece. Boston - Leiden, Brill, 2015, pp. 145-184, pp. 154-155. Henceforth COUREAS 2015. The open collaboration of Theodore with the Latins, regarding
} 
proved far too uneducated to understand them [the books], understanding as much as donkeys from the play of lyre, or scarabs from the scent of perfume. ${ }^{281}$ These remarks evoke the traditional Greco-Roman image of the barbarians, who are generally described as ignorant, oafish people, standing on a level of civilisation which is much lower than that of their GrecoRoman counterparts. ${ }^{282}$

Choniates views Latins as ignorant and hostile towards culture, which per definitionem means Byzantine culture, not the least because this culture is beyond their understanding. ${ }^{283}$ This circumstance is not only a consequence of their lack of knowledge about the humanities and sciences, but also a result of the existing language barrier, that is, their lack of a good command of Greek, which is also a strong marker of their alterity, ${ }^{284}$ their perceived 'alienity' of the Greek world. This linguistic problem, however, as Greek was the evident language of culture for contemporary Byzantine state ideology, definitely brands them as people without any proper erudition and with a very limited knowledge about the world.

\section{V.6. A 'Failing' Western Science?}

Theodoros II Doukas Laskaris (1254-1258) in a letter sent by him to his mentor, Nikephoros Blemmydes, in the autumn of 1253, discusses Western culture from another peculiar point of view. The source deals with the Holy Roman Imperial embassy of scholars, led by the marquis Berchtold von Hohenburg, who were sent to the court of Ioannes III Vatatzes in Nymphaion by emperor Konrad IV (1237-1254). The Western scholars debated with their Byzantine colleagues on different subjects and they tried to solve scientific problems presented by the others, both with the intent of deciding, whether Byzantine or Latin science stood on a higher level in specific fields and in general. ${ }^{285}$

the expressions of strong anti-Latin sentiment in the epistolographic corpus of Choniates, make the cordial relations between him and Theodore, similarly voiced in the letters of the former metropolitan, most interesting.

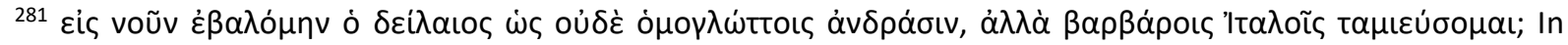
Kolovou 2001, p. 238.

282 JONES, W. R.: The Image of the Barbarian in Medieval Europe. Comparative Studies in Society and History, Vol. 13, No. 4 (Oct., 1971), pp. 376-407, pp. 378-379.

283 ISNENGHI. Laura: La quarta crociata e la questione dell'identita. Spunti per una lettura di alcune fonti bizantine e occidentali, da Nicola Mesarite a Martin da Canal. In Piatti, P. (Ed.): The Fourth Crusade Revisited 1204-2004. Andros (Greece), 27-30 May 2004. Citta del Vaticano, 2008, pp. 104-126, pp. 112-113.

${ }^{284}$ MITSIOU, Ekaterini: The Byzantines and the "others". Between "Transculturality" and Discrimination. In Gastgeber, Christian - DalM, Falko (Eds.): Byzantium as Bridge between West and East. Wien, Verlag der Österreichischen Akademie der Wissenschaften, 2015, pp. 65-74, p. 68.

285 Tinnefeld, Franz. 'Das Niveau der abendländischen Wissenschaft aus der Sicht gebildeter Byzantiner im 13. und 14. Jahrhundert'. BF, no. 6 (1979), pp. 241-80, pp. 254-256. Henceforth TINNEFELD 1979. 
One of the problems presented by Blemmydes, in script, because of his absence, involved the field of sphere geometry, and neither the erudite marquis, nor his scholars could solve it, stating that it was impossible, as it was explained to Theodoros when he asked about the situation. ${ }^{286}$ Following their debacle, the young imperial crown prince, that is, Theodoros, solved the riddle effortlessly, causing a great joy among the Byzantines present, who stated it happily to the stupefied marquis and his entourage that in fact there was a solution. ${ }^{287}$ According to the then heir apparent himself, he proved the superiority of Byzantine science against Latin science, thankfully to his education received from Blemmydes. ${ }^{288}$

This letter presents a perceived Byzantine cultural superiority over the Latins to its audience. The marquis and the Western scholars accompanying him are presented as ones who are incapable of solving the problem in sphere geometry, and are overly confident in their opinion that it means that the problem cannot be solved at all, their alleged aporia invoking a stereotypical reasoning of inerudite persons and schoolchildren when they fail to answer a question, thus belittling the Latin scholars, which sheds a rather unfavourable light on Western European culture in general, as the delegation was logically meant to represent its most educated stratum.

On the other hand, this impression is moderated by the fact that the sole person capable to solve the problem was the crown prince, Theodoros himself, who achieved the education needed for it under the tutelage of Blemmydes, portrayed as an exceptionally learned Byzantine scientist. It suggests that the question of sphere geometry presented by Blemmydes was a complex one indeed, and a very high-level mathematical knowledge was required to solve it, making its solution a glorious achievement for his imperial majesty.

Regarding these circumstances, the failure of the Western delegation in solving the problem serves as an evidence of the inferiority of Latin science in comparison to Byzantine science, but does not point to a seriously backward scientific level, as there was only one

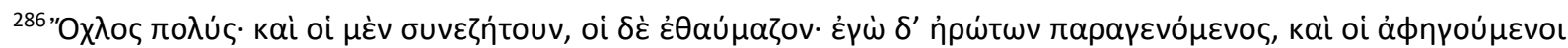

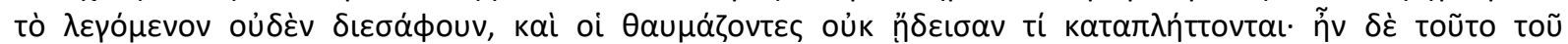

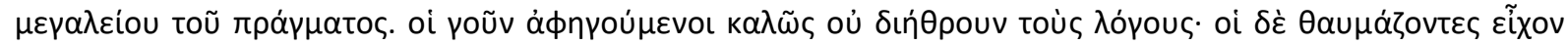

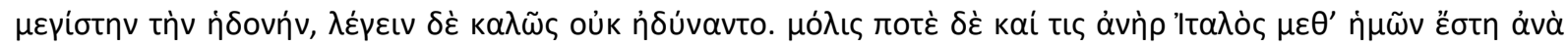

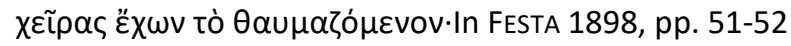

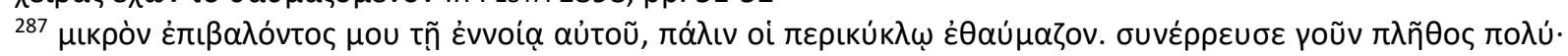

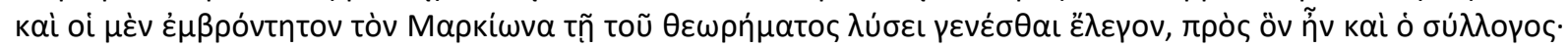

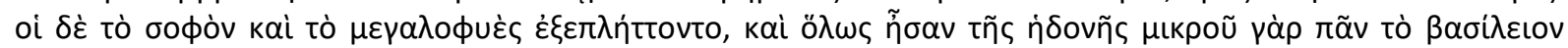

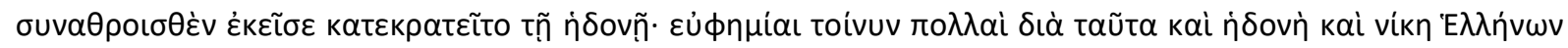

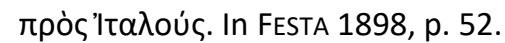

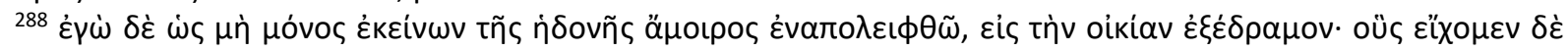

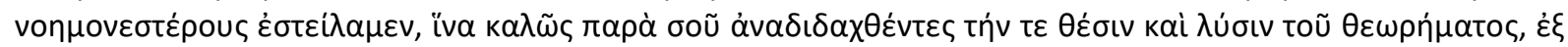

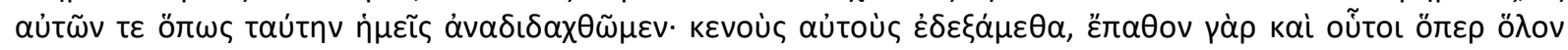
हैं $\alpha \theta \varepsilon$ tò $\beta \alpha \sigma i ́ \lambda \varepsilon$ Iov. In FESTA 1898, p. 52. 
Byzantine person present, who was surely able to provide a solution. The details that point to very embarrassing cultural deficiencies are the answers given by the Latin scholars to their failure, explaining it with claims that the problem could not be solved at the very beginning, suggesting infantile attitudes towards the limits of their own knowledge, in this way humiliating them much more than by simply referring to their lack of an answer, insidiously supporting the argument of Theodoros.

However, another letter of Theodoros Doukas Laskaris, addressed to Andronikos, the metropolitan archbishop of Sardeis, depicts a much more nuanced image of the very same debate. Berchtold von Hohenburg appears decorated with a wreath of positive epithets, among others he does not like strife, is polite, measures his words carefully before speaking and commands Latin science on a high-level. His sole shortcoming is that he only superficially studied Hellenic science. ${ }^{289}$

It is most unfortunate that the same cannot be told about the entourage of scholars accompanying him. These people are depicted as arrogantly proud of their erudition, regarding and presenting themselves as excellent scholars of geometry, astronomy, music, organics, physiology, the theology of the Hellenes, and they are especially proud of their knowledge of ethics, politics and rhetoric. ${ }^{290}$

Disappointingly, the developments during the debates falsified this high view of themselves, as their arithmetic fled, the chords of their music were torn, the foundations of their geometry were in decay, their stereometrics collapsed completely, their astronomy hid away and left only the astrology, but even that was failing and not fully formed.

Even worse, their meteorology lied on the ground, their physiology was diseased, their ethics were anomalous and the politics were not even mentioned, while their rhetoric took flight and fluttered about, their logic missed its point, serving as a great sensation for the Greeks present and becoming infamous. ${ }^{291}$ As the marquis saw these disappointing

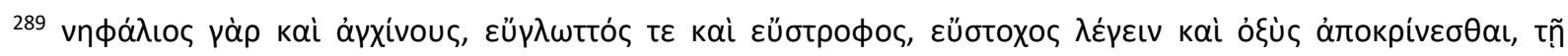

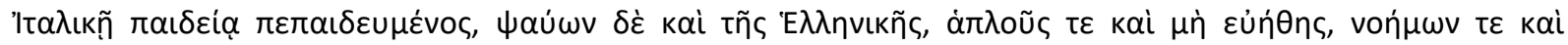

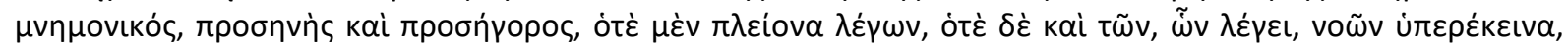

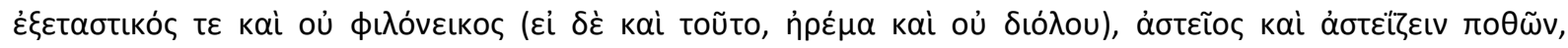

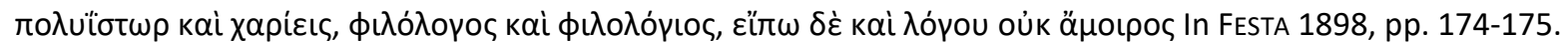

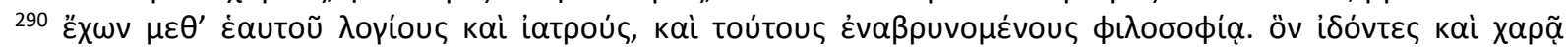

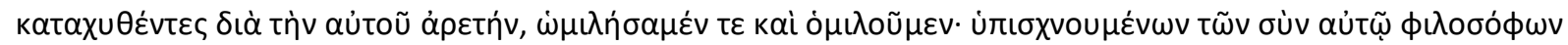

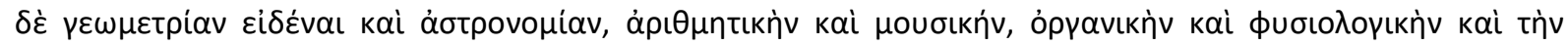

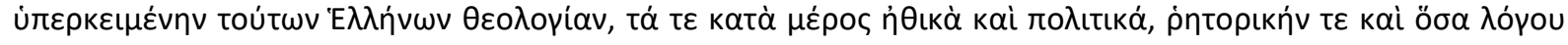

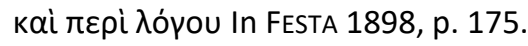

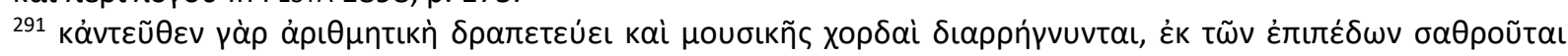

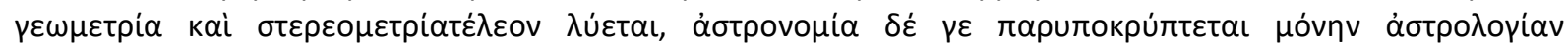


developments, he judged that it was enough, which was most propitious of him at the time, as the calamity [of the Western scholars] had grown large. ${ }^{292}$

The description of the debate in the stadium, the location of which suggests the presence of a wider audience, is organised around three poles: the Byzantine participants and audience, Berchtold von Hohenburg and the Western scholars. The Byzantine scholars and the probably not necessarily so erudite Byzantine audience at Nymphaion are not distinguished from each other. This, as the Greek scholars appear as most competent persons, transmits this impression of intelligence and knowledge to the audience, thus forming an image of a homogenously educated society and providing a very flattering vision of contemporary Nikaian elite society.

The marquis von Hohenburg is depicted as an equal of the Greeks in his intelligence, and a person of moral integrity, only lacking a proper knowledge of Greek science, which can be easily explained through contemporary Byzantine prejudices of Western education, echoed in the letter itself, relieving the marquis from any responsibility of that. In turn, the Western scholars appear as embodiments of failure regarding the fields of many sciences, displaying such a level of ignorance that they do not even realise their intellectual shortcomings.

They are cartoonish representatives of perceived Latin cultural backwardness, which becomes the more pronounced by the clear irony on behalf of Theodoros, as he illustrates their failures in each science with a world play that symbolizes the very opposite of what the science in question is supposed to provide. For instance, he creates strong contrasts for the audience, raises the shortcomings of the Latin scholars to an even higher level, portrays them as the exact opposites of what they are supposed to be, their knowledge standing in an antagonistic conflict with the sciences they should be adept in.

The fact that the marquis is the person, who, after realising the embarrassing production of his entourage, closes the debate, implicitly recognising the superiority of Hellenic science, makes it evident that his presentation as a collection of positive qualities serves mainly as a rhetorical device. Theodoros, portraying him so, affects objectivity, attempting to convey an impression of factful description to his prejudiced and biased depiction of the Latin scholars, making it the more credible. Von Hohenburg's tacit

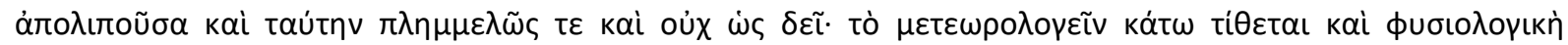

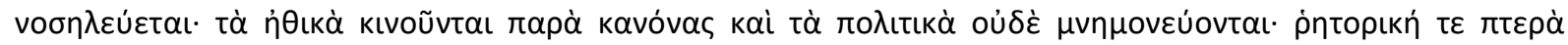

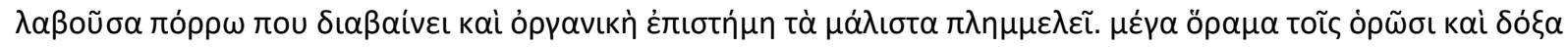

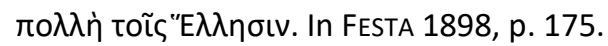

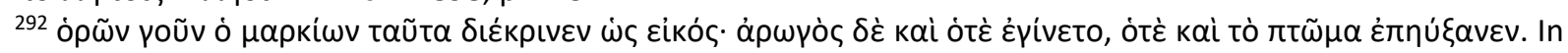
FESTA 1898, p. 175.
} 
acknowledgement of the his delegation's defeat similarly serves as a device to strengthen the credibility of their failure, as it suggests that not only the Byzantines themselves, but also an exceptional Westerner judges the result as a victory of Hellenic science over Latin science. ${ }^{293}$

Stressing the exceptionality of von Hohenburg makes it the more facile to invoke an image of the whole of Latin Christendom being culturally backward, as one 'accidentally' erudite person cannot counterbalance the poor performance of the representative scholars of this civilisation, which suggests that most Latins stand on an even lower cultural level. A comparison with his portrayal as the 'stupefied' marquis in the letter of Theodoros II addressed to Blemmydes, in which von Hohenburg appears as just as ignorant as the members of his entourage, corroborates this reading of his portrayal in the letter sent to the metropolitan of Sardeis.

The main reason behind this difference may be that in the letter addressed to archbishop Andronikos the ideological function is dominant, using the letter as a device of imperial propaganda, voicing the cherished stereotype of Byzantine cultural superiority over the Latins, probably not independently from the less intimate relationship between the crown prince and the metropolitan. In the letter sent to Blemmydes, the mentor and friend of Theodoros Doukas Laskaris, this ideological intent could be less important, surpassed by the wish of the student to glorify himself for his personal achievement to the respected master, wanting to make him proud through that.

Furthermore, the reality behind the representations of the Western delegations provided by the later Theodoros II is also worth considering. Contemporary Western science was more developed then presented by the crown prince, and Konrad IV, son of Friedrich II (1198-1250) had the opportunity to select exceptionally competent scholars for his delegation sent to Nymphaion. However, the fact that the debate was held in Greek had to be a serious disadvantage for the Western scholars, especially as the most important scientific works in a number of fields involved were known to them only through translations, while his Greek opponents read them in Classical Greek. ${ }^{294}$ Taking into account the probable aims of Theodore Doukas Laskaris with his two letters discussing the event, it is logical to assume that he deliberately avoided addressing these factors in the letters at all.

\footnotetext{
${ }^{293}$ The consequent use of the term 'Hellenic' as an equivalent of 'Byzantine' fits well into the cultural trend in contemporary Nikaian high culture. It underlined the continuity of Ancient Greek and Byzantine cultures. RAPP, Claudia: Hellenic Identity, Romanitas and Christianity in Byzantium. In ZACHARIA, Katerina (Ed.): Hellenisms. Culture, Identity, and Ethnicity from Antiquity to Modernity. Farnham, Ashgate, Variorum, 2008, pp. 127-147, p. 142.

294 TINNEFELD 1979, pp. 258-261.
} 
Almost a century later Nikephoros Gregoras, in a letter dated to 1331-1332, addressed to Demetrios Kabasilas, saw the niveau of Latin science similarly problematic. As he described to his friend, three days earlier a group of Latins stood around him [Gregoras] in an astrological debate. The Latins claimed, in a clear contradiction to Aristotle, that the heat of the Sun was not hot by nature, but it acquired its heat during its movement in the spheres, as a result of friction. ${ }^{295}$ Gregoras, after giving a detailed scientific explanation to the phenomenon, states that he did not want to describe everything that is clear for them [himself, Kabasilas and others adept in Byzantine astronomy], that day ended amidst the debate, and finally he agreed with those Latins who gave him such a lecture. ${ }^{296}$

The views of Gregoras on this subject appear not only in his letters, but also in his renowned Solutions. In this collection of brief treatises, the fifth one bears the title Concerning the Sun, that it is hot by nature. In this work Gregoras voices the same views as in his letter addressed to Kabasilas. ${ }^{297}$ Regarding the question of meeting and debating Western astronomers about these problems, Gregoras definitely had opportunities for that, just as reading Western astronomical literature, due to his strong connections with contemporary Cyprus, where king Hugues IV Lusignan (1324-1359) supported astronomy and the dialogue between Latin and Greek scholars of this science. ${ }^{298}$

The most striking attitude presented by the author is irony. Gregoras, perfectly sure in his scientific opinion, facing Latin explanations contradicting his own views, treats them with contempt, stressing that the pertinence of his understanding of the question is not less but 'obvious' to everybody adept in the field of astronomy. Under this he most probably means Byzantine astronomy, not allowing any ground for different views without exclusion from the group of 'serious' astronomers. Besides, Gregoras uses the first-person plural as a covert captatio benevolentiae toward Kabasilas, which should work through its flattering suggestions

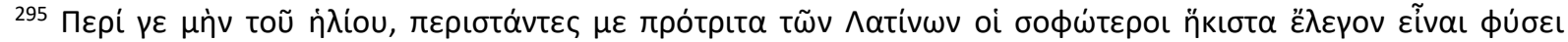

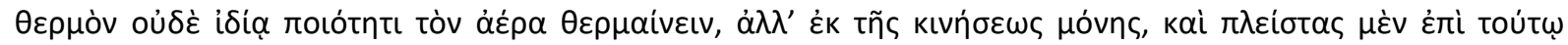

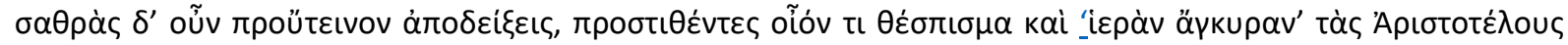

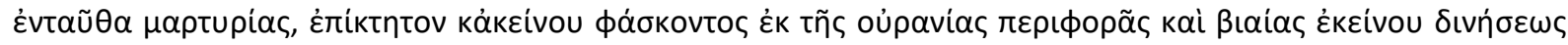

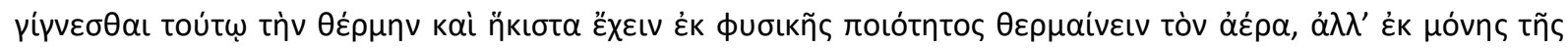

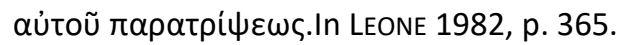

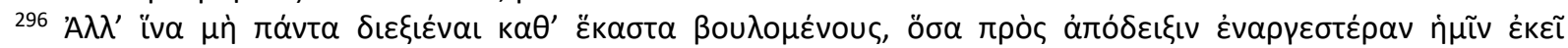

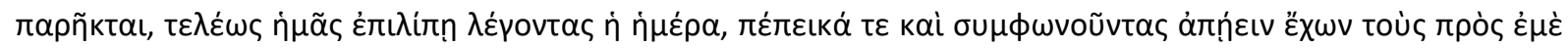

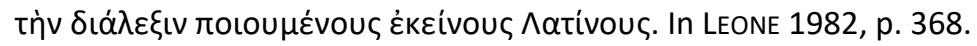

${ }^{297}$ LEONE, Pietro Luigi M. (Ed.): Nicephori Gregorae Antilogia et Solutiones quaestionum. Byz 40 (1970), pp. 471516.

298 PINGREE, David: The Byzantine Version of the Toledan Tables: The Work of George Lapithes? DOP 30 (1976), pp. 86-132, p. 88.
} 
of their own culture standing on a higher level than that of the Latins. What is more, he propounds that both author and addressee belong to an elite group within their culture.

Gregoras also discusses his inability of convincing his Latin colleagues with open sarcasm, suggesting that he gave up any attempts to win them over because it was already too late, and they lacked the understanding needed to see the right of Gregoras. So, he gave them the illusion that they had convinced him, thus portraying them as not only ignorant in their field but gullible too, underlying his own silent victory over them. The letter also implies that the difference between the levels of Latin and Byzantine astronomical knowledge is extremely great, with a clear Byzantine superiority.

It is rather ironic that the theory defended by the Latin astronomers and attacked by Gregoras relied on the ideas of one of the greatest Greek authorities in Medieval Europe: Aristotle. As Aristotle expounds in his Meteorology, he understood that the movement of the Sun is sufficient to explain its heat, which was not a consequence of its nature. ${ }^{299} \mathrm{He}$ also saw a connection between the colour of the Sun and its nature, stating that it seemed to be hot, but its colour was white, as it was not a fiery celestial body. ${ }^{300}$ Because of the great authority commanded by Aristotle, Medieval Western astronomy treated it an axiom that the heat of the Sun was a result of its movement. ${ }^{301}$

\section{V.7. The 'Most Antilogical Latins'}

Besides examples of the failures of Western science, even the questioning of the mere logical thinking of the Latins is present in the sources. Writing to Gregorios Palamas, Barlaam underlines that he [Barlaam] addresses the speeches to the most antilogical Latins. It was necessary for him to hypothesize these things at the beginning of the examination and to put forward these things, of which he knew that they [the Latins] agreed with [them]. ${ }^{302}$

Barlaam begins with a rather harsh verdict on the Latin theologians, as most of his partners in a debate had been such persons, branding them as 'most antilogical', invoking the image of uneducated people, or even worse, mentally challenged ones. The latter one can be

\footnotetext{
${ }^{299}$ LEE, H. D. P. (Ed.): Aristotle: Meteorologica: 1.3.341a.19-24. Loeb Classical Library 397. Cambridge (Mass.) London, Harvard University Press, 1952 pp. 22-24. Henceforth LeE 1952.

300 LEE 1952, p. 24.

${ }^{301}$ Grant, Edward: Planets, Stars and Orbs. The Medieval Cosmos 1200-1687. Cambridge, University Press, 1994 [Reprint 1996], p. 453.

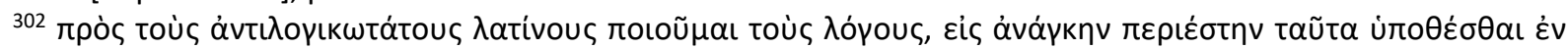

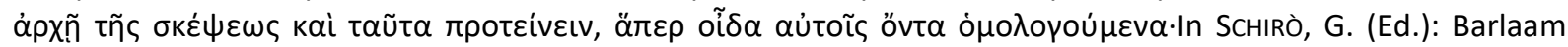
Calabro, Epistole Greche [Istituto Siciliano di Studi Bizantini e Neogreci. Testi e Monumenti 1. Palermo 1954]: 229-330, p. 230. Henceforth SCHIRÒ 1954.
} 
excluded as an interpretation, because of contexts of the letter, and the views promoted by Barlaam in general, not omitting the problem of the futility of having a theological argument with mentally challenged persons.

His claimed solution of beginning his argument with pronouncing teachings, of which there is already an agreement between him and them, and logically between their respective churches, is determined as a necessity. It is a definitely apologetic statement, which implicitly suggests that the intellectual 'limitations' of the Latins demanded this solution. These remarks also convey the impression of this practice being a questionable one, requiring a validation.

Latins are portrayed as separated from the Byzantines by their different religious views and the niveau of their learning. Both separating aspects are framed in ways that tacitly express the perceived higher standing of the Byzantines in both fields. It is a Byzantine intellectual, Barlaam, writing to another Byzantine intellectual, Palamas who defines the 'most antilogical' thinking of the Latin theologians, the crème de la crème of Catholic intellectuals.

It supposes an ability to detect the problem, pointing to a Byzantine intellectual elite 'competent in logic' in contrast to a Latin intellectual elite that lacks this competence. It provokes thoughts that the problem could be even more acute among less educated Westerners, while less erudite Byzantines might perform better than their Western counterparts, mirroring the difference between their intellectuals.

If there are religious differences among communities showing such differences, and the existence of absolute religious truths is supposed, than, it is also very probable that the more 'logical' community will profess views that are closer to these hypothesized truths. So, the possibility of Latin religious views differing from Orthodox ones being true is undermined by the charge of Catholics being 'most antilogical', giving the higher standing for Byzantines also in this field.

The claims of Barlaam discussed above also represent an important tenet of his approach towards debating with Catholic theologians and a key point of confrontation in his debate with Palamas. Barlaam promoted that in order to facilitate convincing the Latins, their Orthodox opponents should begin their theological arguments with such teachings about which the two Churches are already in agreement, seeing a stark contrast between his own approach and that of Palamas in this respect. ${ }^{303}$

\footnotetext{
303 PODSKALSKY, Gerhard: Theologie und Philosophie in Byzanz. Der Streit um die theologischr Methodik in der spätbyzantinischen Geistesgeschichte (14./15. Jh.), seine systematischen Grundlagen und seine historische Entwicklung. Byzantinisches Archiv 15. C. H. Bech'sche Verlagsbuchhandlung, München, 1977, p. 144.
} 


\section{V.8. Westerners Who Admire Greek Paideia ...}

In a letter sent to Manuel Chrysoloras, Isidoros of Kiev compares the Empire's ill fate with the incredible luck of Chrysoloras, who was a guest at the table of the great French king because of his fame. He incites Manuel to sail to the English through the Atlantic Ocean, and speak with them, so they could be useful ones for the nation of the Romans. ${ }^{304}$

Although the letter is not dated, it is known that the embassy of Chrysoloras to Paris and London, accompanied by Konstantinos Rhalles and Alexios Dishypatos, took place in 1408, which dates the letter of Isidoros to the very same year, ${ }^{305}$ after the Parisian phase of the official journey. Curiously enough, it also means that the French king in question has to be Charles VI (also known as Charles the Mad, 1380-1422), who, because of his escalated insanity, was unable to rule his realm himself, being under the control of a regency, and certainly did not command considerable respect in contemporary Europe.

However, in this case, it is not the person of the mentally ill king that provides the importance of the visit of Chrysoloras, but the place itself and its meaning. The famous Greek scholar was greeted by the regency as a guest in the royal court at Paris, which demonstrates how respectable he was in their eyes.

The use of the epithet 'great' to the unfortunate Charles VI may be a mere gesture of courtesy, but it seems to be more probable that it serves to stress the importance of his office as ruler of France, a great power, and through that to implicitly praise the fame and respect Chrysoloras had achieved in the West, as the main purpose of Isidoros in this part of the letter can be determined as praising his friend, the notable scholar.

Chrysoloras visited the court of Charles VI and that of Henry IV (1399-1413) with the objective to gain support against the Ottoman Empire, as France and England were the leading powers of contemporary Europe, so securing the support of preferably both states was of especially great importance. Isidoros praises Chrysoloras as a person perfectly capable of accomplishing his mission in England, which gesture, besides of nursing their close

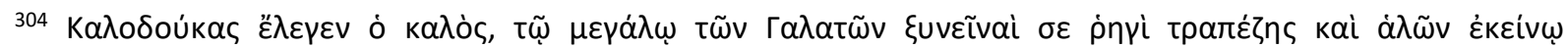

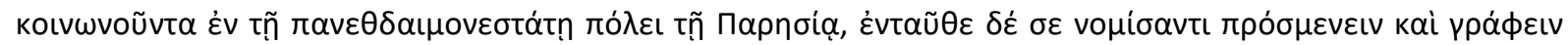

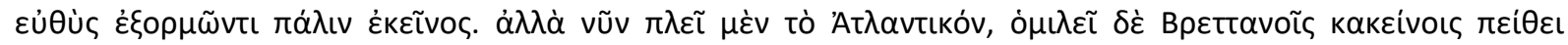

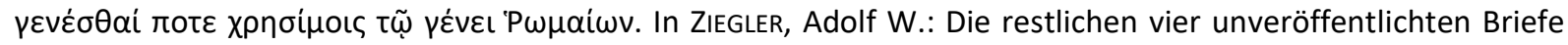
Isidors von Kiev. OCP 18 (1952), pp. 135-142, p. 140.

305 THORN-WICKERT, Lydia: Manuel Chrysoloras (ca. 1350-1415). Bonner Romanistische Arbeiten 92. Frankfurt am Main, Peter Lang, 2006. pp.76-77. Henceforth THORN-WICKERT 2006.
} 
friendship, may have served to enhance the self-confidence of Chrysoloras, which was needed for his success.

The relationship between the three ethnic communities mentioned in the letter, the French, the English and the Byzantines is viewed through the scope of international relations by the source. Chrysoloras has to forge a Byzantine-French and a Byzantine-English alliance against the advancing Ottoman Empire by his embassies. The most important reasons behind these aims are the differences between Byzantium and the two other states presented by the letter: the vast disparity between the military potential of Byzantium and the ones of England and France.

In this very important field, crucial to the handling of the Ottoman conquest, the advantage is obviously on the side of the French and the English, respectively. The intent of the Byzantine government is also clear, as it would like to harness these Western military resources to solve its existential threat, as it is admitted by the author by his allusion to the achievable future usefulness of the English for the 'Romans'. But culturally, the advantage is still attributed to Byzantium, suggested by the appreciation towards Kalekas in the French court because of his fame as a scholar.

\section{V.9. ... Westerners Who Acquire Greek paideia ...}

Westerners are not featured solely in the roles of admirers of Byzantine science. Writing to Jacopo Angeli de Scarperia in Florence, from Perai, Constantinople, in the spring of 1397, Manuel Kalekas remembers how his friend, Jacopo came to Constantinople to learn Greek in late 1395, in spite of the siege of the city on land by the Turks (1394-1402), ${ }^{306}$ and the beginning of their friendship. He is happy that Angeli arrived back to Florence unharmed, supposing that he was accompanied by his teacher, Manuel Chrysoloras, and wishes him success in his studies, encouraging him to use what he knows to the good of Latins and Greeks too. Kalekas asks his friend to use Greek in his letters, as he (Kalekas) is not fluent in Latin. $^{307}$

\footnotetext{
306 WEISS, Roberto: lacopo Angeli da Scarperia. In Medieval and Humanist Greek. Collected Essays by Roberto Weiss. Padova, Editrice Antenore, 1977, pp. 255-277, pp. 258-259. First published in Medioevo e Rinascimento. Studi in onore de Bruno Nardi, II, 1955, Firenze, pp. 803-817.

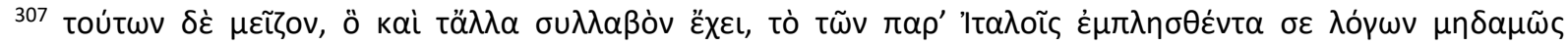

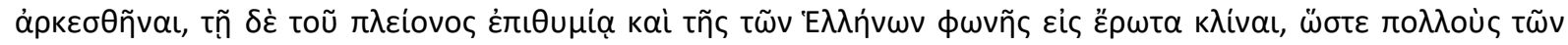

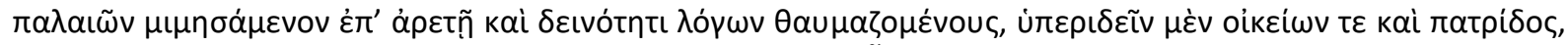

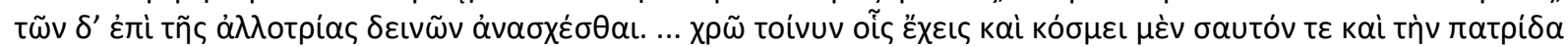

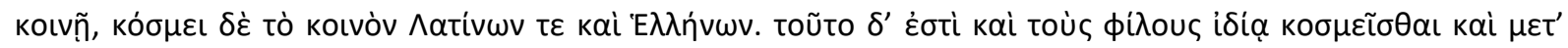


The reference made to the adventurous journey of Scarperia to the Byzantine capital, at that time under siege by the Ottoman sultan Bayezid I (also known as Yildirim (Lightning), 1389-1402), is known for the history of Renaissance learning. Jacopo Angeli de Scarperia was that later famous student of Manuel Chrysoloras, whose attachment to his mentor and Greek culture proved to be so strong that, when his master decided to return to Constantinople, he risked the perilous voyage with him. ${ }^{308}$

Furthermore, the return of Chrysoloras to Florence, who was accompanied by Scarperia, also proved to be a significant event in the history of Renaissance erudition. The Greek scholar was invited to the Tuscan city by the signoria of the Republic of Florence to teach Greek, with effects beyond their expectations. Chrysoloras not only made a great impression to much of Northern Italy, but besides writing his own Greek textbook, began the translations of the Republic of Plato and the Geography of Ptolemy. The latter project was eventually finished by Scarperia. ${ }^{309}$

The presentation by the pro-Latin Kalekas underlines the courage of Scarperia for travelling to the besieged Constantinople, which deed is implied to be strongly connected to his desire for learning Greek and studying Byzantine science. The most interesting detail is that the boundary of ethnicity between the Byzantines and the Italians seems to dissolve in the case of a person so sympathetic to Greek culture and open to the Byzantines like the famous humanist, who appears not only as a personal friend, but almost as a fellow Byzantine intellectual.

This suggests that, instead of lineage, the ability to speak the language of a people, sharing their education, sharing their system of values and attachment to their country are regarded as the characteristics of ethnicity by Kalekas. The view that these are the markers that define boundaries between ethnic communities represents a remarkably open concept of

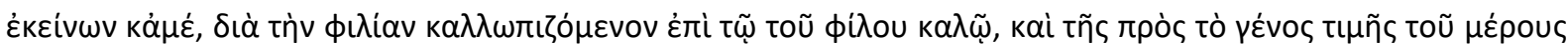

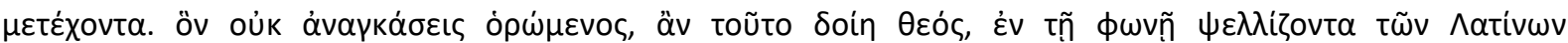

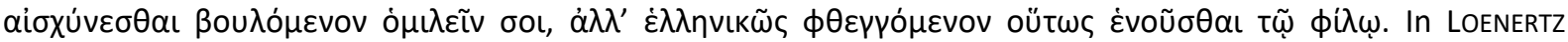
1950, pp. 191-192.

${ }^{308}$ GEANAKOPLOS, Deno John: A Reevaluation of the Influences of Byzantine Scholars on the Development of the Studia Humanitatis, Metaphysics, Patristics, and Science in the Italian Renaissance (1361- c. 1531). In GeanAKoplos, Deno John: Constantinople and the West. Essays on the Late Byzantine (Palaeologan) and Italian Renaissances and the Byzantine and Roman Churches. Madison, The University of Wisconsin Press, 1989, pp. 38-67, p. 57.

${ }^{309}$ GeanaKoplos, Deno John: Italian Renaissance Thought and Learning and the Role of the Byzantine Emigré Scholars in Florence, Rome, and Venice: A Reassessment. In GeanAKoplos, Deno John: Constantinople and the West. Essays on the Late Byzantine (Palaeologan) and Italian Renaissances and the Byzantine and Roman Churches. Madison, The University of Wisconsin Press, 1989, pp. 3-37, pp. 19-20. 
ethnicity, in which belonging is a question of choice and the fulfilment of cultural criteria, instead of birth.

The capability of the Latins to acquire a Byzantine erudition is similarly present in a letter of Manuel II, written to Guarino 'the Italian', ${ }^{310}$ sent from Constantinople in 1417 to Venice. The emperor asks Guarino to translate his Funeral Oration for Theodoros, Despot of Morea, to Latin, and, if he would like, to his own language. But, if the work is unworthy being shown to others, he authorizes Guarino to cast it away, as it would be also a gesture of kindness by him in that case. ${ }^{311}$

Guarino the Italian is identical with the famous humanist Guarino dei Guarini, or Guarino de Verona, who met Manuel Chrysoloras in 1403, and travelled to Constantinople in the very same year to learn Greek by the great scholar, where he stayed until $1408 .{ }^{312}$ He even participated in the diplomacy of the Empire, for instance, he composed the Latin version of a Byzantine-Venetian treaty in 1406, which points to his fast learning of the Greek language and his close relationship with the Byzantine court. ${ }^{313}$

Regarding the Funeral Oration for Theodore, Despot of Morea it is worth mentioning that when Theodore Palaiologos, younger brother of Manuel II and despot of Morea passed away in 1407, the emperor soon began to compose his funeral oration, and he chose the mentor of dei Guarini, Manuel Chrysoloras as the confidential corrector of his text. The fact that the emperor asked him to help improve the text instigated Chrysoloras to compose his famous Epistolary Discourse, addressed to Manuel II. Beyond trust in the command of Greek and Latin displayed by dei Guarini and his friendship with the emperor, his master's participation in the creation of the Greek original may also have contributed to his nomination as the Latin translator of the oration. ${ }^{314}$ As his imperial majesty had sent a copy of his work to

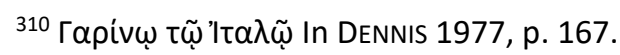

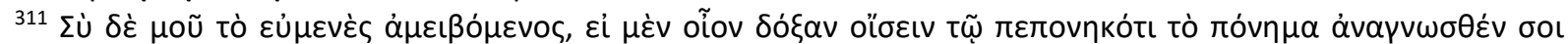

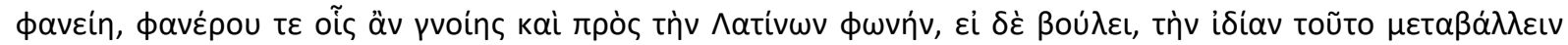

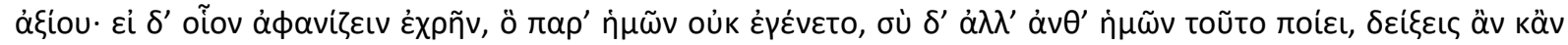
$\tau \tilde{\omega} \delta \varepsilon$ tòv $\varepsilon u ̈ v o u v$. In DENNIS 1977, p. 169.

312 THORN-WICKERT 2006, p. 67.

${ }^{313}$ As Barker stated, the fact that only this one letter in the corpus of Manuel II is addressed to dei Guarini, can hardly mirror the exact proximity of the humanist scholar to the emperor, as the sixty-three letters included are evidently just a small part of the epistolographic output of Manuel II. Furthermore, even his own mother, the empress dowager Helene Kantakouzene, is addressed in only one letter in the collection. BARKER, John W. Manuel II Palaeologus (1391-1425): A Study in Late Byzantine Statesmanship. Rutgers Byzantine Series. New Brunswick, N.J: Rutgers University Press, 1969, p. 430. Henceforth BARKER 1969.

314 DENDRINOS, Charalambos: Co-operation and friendship among Byzantine scholars in the circle of Emperor Manuel II Palaeologus (1391-1425) as reflected in their autograph manuscripts. Paper given at the conference "Unlocking the Potential of Texts: Interdisciplinary Perspectives on Medieval Greek" at the Centre for Research
} 
Manuel Chrysoloras earlier, it is also possible that Guarino had already knew the oration when the letter was written, but it is certain that he never took under the task of actually translating it. $^{315}$

It is impossible to assert whether Manuel II was honest claiming that he began to compose his oration only to commemorate his late brother, or he merely pretended it. His statements on this subject, just like the ones on himself being doubtful with regard to the qualities of his work, may be just as sincere as feigned. What seems to be plausible, however, is that the close relationship between him and dei Guarini existed, and the humanist possessed the command of Greek and Latin required by the task. The impression conveyed by the letter is that of friendship and of a knowledgeable scholar, who is honest and capable of enhancing the willingness of Guarino to undertake the work of translation.

The fact that the emperor requested a translation from Guarino, does not simply demonstrates the axiom of language constituting an ethnic boundary. His request only has a meaning if there is an audience capable of evaluating the translated work, due to their erudition. The request of Manuel II supposes the existence of such an educated audience, who lack merely the command of Classical Greek, but not the understanding of rhetoric. With this gesture, the emperor treats the traditional image of the Latins, that is, people who are culturally backward en bloc, as invalid, presuming only limited differences regarding the cultural level.

In a letter of him (date unknown), Isidoros of Kiev similarly praised the remarkable intellect of dei Guraini. As the future cardinal states, the applause made by those who acknowledged the letter of him [the one of dei Guarini], that letter that was heard all around the countryside, and it was not easy for them [Isidoros and the audience - another example of letters read aloud] to understand it. He also claims that he thought about the circumstance how useful dei Guarini can be for the cities, who decorates the homeland, and, for the sake of the homeland, the whole of Italy with the voice of the homeland, and decorates Hellas with the education of those Hellenes. ${ }^{316}$

in the Arts, Social Sciences, and Humanities, University of Cambridge, 18-19 July 2006; ( 2007 , Charalambos Dendrinos. URL: http://www.mml.cam.ac.uk/greek/grammarofmedievalgreek/unlocking/Dendrinos.pdf ; last accessed 4th November 2019, pp. 1-17, pp. 14-15.

315 DenNIS, George T: The Reign of Manuel II Palaeologus in Thessalonike 1382-1387. Orientalia Christiana Analecta 159, Roma, Pont Institutum Orientalium Studiorum 1960, p. 168. Henceforth DeNNIS 1960.

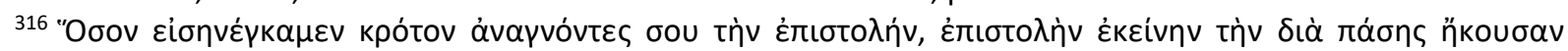

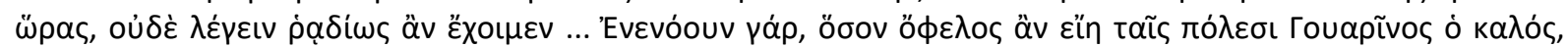

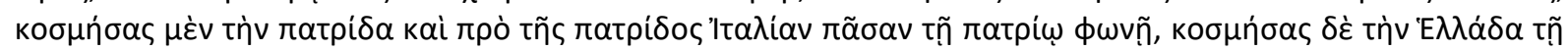


It is worth noting that a project involving both Guarini and Isidore was mentioned above, as the future metropolitan of Kiev was the personal scribe of Manuel II, who copied the final version of Funeral Oration for Theodore, Despot of Morea in 1415. It was similarly Isidoros who informed the emperor about the effects of an earlier draft of the oration, which was held at one of the first anniversaries of the death of the despot, Theodore Palaiologos. ${ }^{317}$ Guarino might have received the text for translation in a copy written by his friend, Isidoros, ${ }^{318}$ and their strong bound probably influenced the friendly tone of the letter.

When Isidoros mentions 'homeland', he most probably refers to the remaining Byzantine Empire, then continues with 'the whole of Italy', closing his train of thought with Hellas itself, used as a synonym for the remaining Byzantine territories and the other parts of the Greek-speaking world, mirroring the greater identification with Ancient Greece among educated Byzantines from the period of the Empire of Nikaia.

As the later cardinal praises dei Guarini for decorating all three geographical areas with 'the voice of the homeland', interpretation becomes less complicated. This statement is clearly a praise of the remarkably good command of Classical Greek displayed by dei Guarini, with which he served the Byzantines as a decoration of Byzantium, especially as a foreigner, then the whole of Italy with his own educational activities, and thus bringing glory for the entire Hellenic world. Following this logic, 'the cities' can be understood as the Italian cities where dei Guarini was active as a scholar.

One can draw a parallel between this solution and the aforementioned description by Manuel Kalekas of the friend and fellow disciple of dei Guarini, Jacopo Angeli de Scarperia, as both texts present the humanist in question as a 'quasi-compatriot'. Dei Guarini overwrites his Italian ethnic background with his Hellenic erudition, and thus becomes more Greek than most of ethnic Greeks, who lack such knowledge, who cannot comprehend Classical Greek, the language of their forefathers, and who find a worthier representative of themselves in dei Guarini than in their contemporary descendants.

This argument was a recurring response of pro-Western Byzantines against claims of Byzantine cultural superiority over the Latins and the alleged cultural incompatibility of the

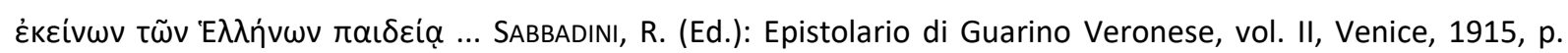
680.

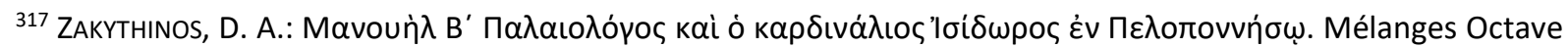
et Melpo Merlier, III (=Collection de I'Institut Francaiş d'Athènes 94 (1957), pp. 45-69, pp. 47-50, see also DENNIS, 1960, p. 15

318 LEONTE, Florin: A Brief History of the Morea seen Through the Eyes of an Emperor-Rhetorician. Manuel II Palaiologos's Funeral Oration for Theodore, Despot of Morea. In GERSTEL, Sharon E. J. (Ed.): Viewing the Morea. land and People in the Late Medieval Peloponnese. Washington DC, Dumbarton Oaks Research and Library Collection, pp. 397-417, p. 399 
Byzantines and the Latins, and was already present in the works of Demetrios Kydones himself since the mid-1360s. ${ }^{319}$ Furthermore, as Guarino educated groups of his compatriots in the Greek language and Byzantine culture, certain Italians acquired a Hellenic paideia, so the argument can be generalised. The old stereotype of the Latins being collectively the inferiors of Byzantines regarding culture is dismissed by Isidoros of Kiev, his words invoking a bridgeable and actually tightening cultural gap between the Italians and the Byzantines.

In his letter dedicated to Konstantinos Palaiologos, the later Konstantinos XI, written in $1433,{ }^{320}$ Scholarios discloses his interesting thoughts about Western philosophy and theology. According to him, the foreign wisdom, under which he understands the one of the Latins, seemed to him very useful for [his] aim, as he has actually become familiar with the language of the Latins and read through not few Latin books, many from the ancient [period], not fewer from the 'middle' [period], and most from this newer [period], which are more accurate regarding their thought. The teachers of the Latins were not unaware of either Porphyrios, or Alexandros, or Ammonios, or Simplikios, or Themistios or about the other ones like them. ${ }^{321}$

Multiple boundaries between the Latins and the Byzantines are addressed above by Scholarios. The most evident of these is constituted by different ethnicity as Latin wisdom is defined as 'foreign', stressing ethnic heterogeneity. Another one is presented by language, as Scholarios stresses that he has become familiar with the language of the Latins, in this case, obviously the Latin language, the language of Catholic theology. This remark also enhances the impression of the competence displayed by Scholarios, supporting his arguments regarding Westerners.

The claims about him reading a lot of Western theological works from the 'ancient', 'middle' and 'newer' eras of Catholic theological thought, which chronological units remain undefined by Scholarios, have a very similar effect of casting the light of competence on the later patriarch, as he depicts himself as being very read in Catholic theology and philosophy.

\footnotetext{
${ }^{319}$ See his speech 'On Accepting Latin Aid', delivered in 1366, in Constantinople, arguing among others with the perceived strong cultural unity of the Greeks and the Latins. In KIANKA, Frances: Demetrios Kydones and Italy. Dumbarton Oaks Papers, Vol. 49, Symposium on Byzantium and the Italians, 13th-15th Centuries (1995), pp. 99-110, p. 103.

${ }^{320}$ GILL, Joseph: George - Gennadius Scholarius. In GILL, Joseph: Personalities of the Council of Florence. Basil Blackwell, Oxford, 1964, pp. 79-94, p. 79.

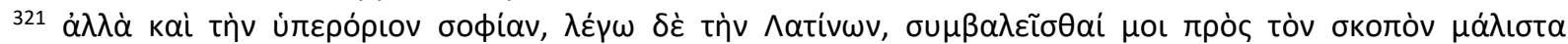

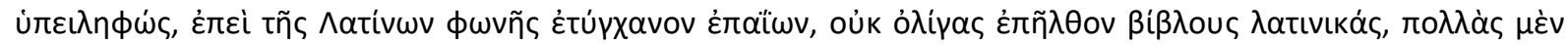

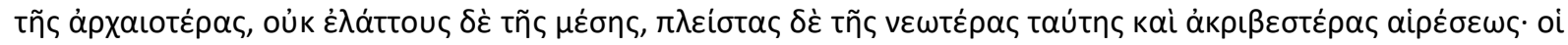

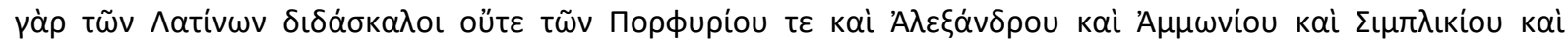

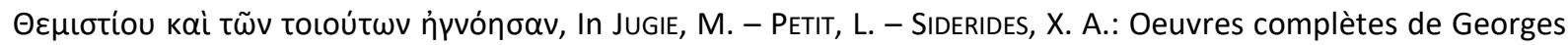
(Gennadios) Scholarios, vol. 7, Paris: Maison de la bonne presse, 1936: 1-6, p. 3 Henceforth JUGIE 1928-1936.
} 
His good command of Latin and diligent reading made him able to identify the second boundary addressed by him, which presents itself on the field of culture.

Latin teachers, logically understood as theologians, are claimed to have read the works of Porphyrios, Alexandros, Ammonios, Simplikios, Themistios and those others understood as being similar to them by Scholarios. It suggests that the Latin theologians and philosophers, being eminent Western intellectuals, had an excellent erudition. As the newer works are marked as being more accurate regarding their thought, Latin culture is claimed to have demonstrated its potential for development. It invokes a suspicion that the general cultural niveau of the Latin world might be similarly impressive with promising prospects.

It is also interesting to examine the catalogue of names mentioned by the author, as all of them can be identified as influential philosophers of Late Antiquity. Porphyrios (234-305) was an influential Neoplatonist thinker, commentator of both Plato and Aristotle, and a student of Plotinos. ${ }^{322}$ Alexandros can be identified with the peripatetic philosopher and commentator of Aristotle, Alexandros Aphrodisieus (fl. ca. 200). ${ }^{323}$ The name Ammonios refers to Ammonios Hermeiou (ca. 440-ca. 520), a Neoplatonist philosopher and commentator of both Plato and Aristotle. ${ }^{324}$

Examining further the list of Scholarios, Simplikios is identical with Simplikios Kilix (ca. 490-ca. 560), a notable commentator of Aristotle, ${ }^{325}$ while Themistios can be identified as Themistios Euphrades, a peripatetic (i.e. Aristotelian) thinker. ${ }^{326}$ So, although not all of them belonged to the peripatetic school, all of the philosophers mentioned by the author were influential in the study of the Aristotelian corpus.

It is important for the interpretation of these remarks to understand the concerns of their author at the time of writing. Scholarios had a strong interest in theology and believed that peripatetic philosophy provided better support for this discipline than Platonism. Furthermore, he understood Western Thomism as a great example of not only using Aristotelian thought as

\footnotetext{
322 Karamanolis, George: Porphyry: The First Platonist Commentator on Aristotle. Bulletin of the Institute of Classical Studies. Supplement, 2004, No. 83, Philosophy, Science and Exegesis in Greek, Arabic and Latin Commentaries: Volume One (2004), pp. 97-120, pp. 98-100.

${ }^{323}$ Fazzo, Sylvia: The 'Metaphysics' from Aristotle to Alexander of Aphrodisias. Bulletin of the Institute of Classical Studies, 2012, Vol. 55, No. 1, Ancient Philosophy in Memory of R. W. Sharples (2012), pp. 51-68, pp. 66-68.

324 VerRYCKEN, Koenraad: La Métaphysique d'Ammonius chez Zacharie de Mytilène. Revue des Sciences philosophiques et théologiques, Avril 2001, Vol. 85, No. 2 (Avril 2001), pp. 241-266, pp. 241-242.

325 HADOT, Ilsetraut: Aristote dans l'enseignement philospohique néoplatonicien: Les préfaces des commentaires sur les Catégories. Revue de Théologie et de Philosophie, 1992, Troisième série, Vol. 124, No. 4 (1992), pp. 407-425, p. 408.

${ }^{326}$ DOWNEY, Glanville: Themistius and the Defense of Hellenism in the Fourth Century. The Harvard Theological Review, Oct., 1957, Vol. 50, No. 4 (Oct., 1957), pp. 259-274, pp. 259-260.
} 
an auxiliary for theology, but also developing it. Meanwhile, he was disappointed by the state of learning in the Byzantine world. So, assembling the above list of philosophers and praising Latin erudition were both in accord with his contemporary attitudes.

\section{V.10. ... and Byzantines Who Acquire Latin Paideia}

However, the exchange of culture in the era was far from restricted to one direction. In a letter written to Leon Bardales (date and place unknown) Maximus Planoudes complains about an uncomfortable experience he had in relation to one of his cultural projects. He translated a book of Boethius from Latin to Greek and lent the translation to a doctor in Ephesos. However, four years had passed, and the doctor was still unwilling to return the book to Planoudes, although he was unable to give any excuse for his questionable behaviour. The disappointed Planoudes asks aid from his friend, Bardales, to make the doctor change his mind and return the manuscript. ${ }^{327}$

The book in question is a reminiscence of the rediscovery of Classical Latin culture, in which Maximos Planoudes had an eminent role, providing his contemporary Byzantines with translations of Augustinus, Boethius, Pseudo-Cato, Pseudo-Cyprian, Cicero, Iuvenalis, Macrobius and Ovidius. ${ }^{328}$ The manuscript mentioned in the letter is clearly a result of this project of translation, most probably a Greek version of the Consolatio philosophiae from Boethius, as this work was definitely translated by Planoudes and achieved certain fame even in contemporary Byzantine intellectual life. ${ }^{329}$

Therefore, the ethnonym 'Latin' here designates Latin as the language of the original text written by Boethius, with a possible inclusion of the culture using this language. And the remarks of Planoudes on his translation have important implications, especially viewed in context. If any translation is made of a text, it usually happens due to a perception that a certain group will regard the translated work as important. This importance may be meant in a positive sense (the original offering 'enlightening' thoughts, entertainment, etc. that should be disseminated to a certain audience), or in a negative sense (the original representing regrettable views, etc., and that should be demonstrated to a certain audience).

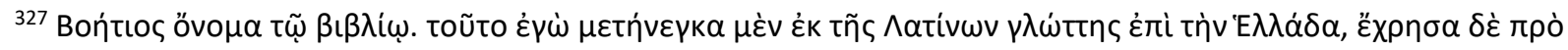

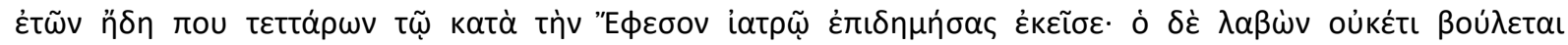

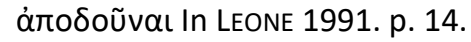

${ }^{328}$ SCHMITT, Wolfgang O.: Lateinische Literatur in Byzanz. Die Überestzungen des Maximos Planoudes und die moderne Forschung. JÖB 17 (1968), pp. 127-147, pp. 128-129. Henceforth SCHMITT 1968.

${ }^{329}$ SCHMITT 1968, p. 133.
} 
Regarding the words of Planoudes on him translating the book merely in the light of these factors, he surely attributed an importance to making a Greek version of the Latin original. Moreover, considering his life, more precisely, his deep interest in Latin-speaking culture and various cultural projects connected to this culture, he clearly understood the Consolatio philosophiae as a philosophically valuable intellectual product of Latin culture.

It implies that the Latin culture of Late Antiquity was capable of creating a philosophical work still relevant almost eight centuries later, and, from a Byzantine point of view, it was Medieval Western European, similarly 'Latin' culture that preserved it for such a long period, presumably for an appreciation of its values. This tightens the difference between the Latins and the Byzantines in the field of culture, traditionally regarded as vast by the Byzantines, by accepting Westerners as being capable of producing philosophical works that can enrich the Byzantines intellectually.

However, the sources also show that, while Planoudes was not alone with his appreciation for 'Latin' culture, such views were rather far from being dominant in Byzantine society. Nearly a century later another Byzantine scholar, Manuel Chrysoloras faced not only the problem of assessing Latin cultural products, but retorsions by the authorities merely for accessing them.

The case is addressed by Demetrios Kydones, in a letter addressed to a friend of him, an unknown judge, sent to Constantinople, dated to 1386. The judge has confiscated a book from another friend of Kydones, Manuel Chrysoloras, because it contained writings of Latin authors. The judge also outspokenly criticized Chrysoloras for his 'excessive sympathy' towards Latins. According to his own words, Kydones cannot help but notice that this accusation could be used against the judge too, as he has taken the book and is unwilling to give it back. Furthermore, Kydones, the judge's friend could suffer the very same attacks as he shares the same interests with Chrysoloras. ${ }^{330}$

Unfortunately, the letter does not contain any exact details about the volume in question, except for that it contained certain works of Latin authors. Therefore, it cannot be decided whether its contents were regarded as potentially subversive by the unnamed judge, or simply it containing texts from Latin authors triggered his action against Chrysoloras, or these two aspects together made him confiscate the book. Both factors alone and in pair could

\footnotetext{
330 In LOENERTZ, Raymond - Joseph, Démétrius Cydonès, Correspondance [Studi e Testi 208. Vatican City:
} Biblioteca Apostolica Vaticana, 1960]: 1-417, pp. 301-302. Henceforth LOENERTZ 1960. 
be more than sufficient to question the loyalty of the humanist scholar to Orthodoxy and make him suspicious in the eyes of the Constantinopolitan authorities.

The purpose of Chrysoloras obtaining the book according to Rollo, that is, merely learning the Latin language, ${ }^{331}$ similarly cannot be decided due to the scarcity of information, but could be an apologetic argument by Chrysoloras, although its acceptance definitely relied on the good will of the authorities. If the scholar used this excuse, the fact that Kydones wrote to the judge to return the manuscript means that Chyrsoloras failed to convince the confiscator.

As Thorn-Wickert states, there is a chance that the book mentioned by Kydones is identical with one of the two Latin books known to be in the library of Manuel Chrysoloras, namely the Logic of William Ockham and the Rhetoric by Marcus Tullius Cicero, but this question cannot be answered without any further information. ${ }^{332}$ The latter work could also raise official concerns because it was written by an openly polytheist author, but Kydones claims that the judge only disparaged Chrysoloras for being 'too sympathetic towards the Latins', not mentioning the possible dangers of 'pagan' erudition to the salvation of the reader, which circumstance weakens the case for identification.

A very interesting aspect of the case is that Kydones clearly tries to mediate between his two friends after Chrysoloras informed him about the incident, that is, the personal network of Manuel Chrysoloras is at work, whether or not at his instigation, to shelter him against the sanctions of the authorities, given as a response to his Latin education and proLatin sympathies. The intervention by Kydones, even if his letter corpus notable in extent (450 letters!) does not contain any pieces addressed to Chrysoloras, clearly points to his sympathy being strong enough for the young scholar to use his influence in his favour, suggesting that their friendship was more than a mere epistolographic cliché. ${ }^{333}$

It is worth mentioning that the use of patronage to avoid sanctions was a recurring element in the life of Chrysoloras, becoming more open and effective from the 1390s, when his close friend, Manuel II Palaiologos (1391-1425), inherited the imperial throne, making it

\footnotetext{
${ }^{331}$ Rollo, Antonio: Problemi e prospettive della ricerca su Manuele Crisolora. In MAISANO, Riccardo - Rollo, Antonio (Eds.): Manuele Crisolora e il ritorno del greco in Occidente: atti del Convegno internazionale, Napoli, 26-29 giugno 1997. Napoli, Istituto universitario orientale. Dipartimento di studi del mondo classico e del mediterraneo antico, 2002, pp. 31-86, pp. 38-39.

332 THORN-WICKERT 2006, pp. 33-34.

333 Tinnefeld, Franz: Die Briefe des Demetrios Kydones. Themen und literarische Form. Mainzer Veröffentlichungen zur Byzantinistik 11 (PRINZING, Günter Hrsg.) Harrasowitz Verlag, Wiesbaden, 2010, p. 117. Henceforth TINNEFELD 2010.
} 
easier for Manuel Chrysoloras to spend the decade with establishing his unique reputation among Italian humanists. ${ }^{334}$

The argumentation furthered by Kydones proves to be a resourceful one, using three connected arguments. The very first is the friendship between him and the judge, which translates as reciprocity demands the official to return the book. The second argument builds upon the first one: it parallels Chrysoloras with Kydones, pointing out that Kydones shares the intellectual curiosity of the young scholar toward Latin culture, so it could be him, the old friend of the judge, who is disparaged for his taste and whose property is confiscated. Finally, the third one is a thought experiment, ironically playing with the possibility of the judge being charged with the same accusations, as he did exactly what Chrysoloras: he kept a Latin manuscript by himself.

This ironic remark underlines the strong friendship between Kydones and the unnamed addressee, just like the lack of fear of the former mesazon. It may also suggest that Kydones was rather confident in the success of his intervention on behalf of Manuel Chrysoloras. The display of this organised yet playful argumentation makes it the more unfortunate that the outcome of the case remains unknown.

However, the arguments used by Kydones also have other aspects, regarding Western erudition. If there was no reason why the judge should have confiscated the book and disparage Chrysoloras for his overly pro-Latin sentiment, it also means that the volume does not pose any danger. This view supposes that, even at the worst case, the contents of the manuscript possess a limited subversive potential and even that is successfully neutralised in the hands of its Chrysoloras, but it is rather just a harmless book. The latter option is supported by the fact that Kydones openly confesses his own interest in Latin culture. It also means that the opinion of Western culture being definitely harmful is challenged by Kydones.

Furthermore, the circumstances that two already noted scholars, one of them a former mesazon of the Empire, take interest in Western culture and study its texts suggest that this culture is able to produce works that are relevant even with Byzantine standards. This invalidates the traditional Byzantine view of Westerners being culturally backward people in comparison to them, even allowing the opportunity of 'Latin' civilisation surpassing the Byzantine in certain aspects.

\footnotetext{
${ }^{334}$ BARKER 1969, p. 261.
} 
In one of his letters, written to an anonym former disciple who became his friend, sent to Milan or Pavia from Crete, in 1400-1401, he states that his former student speaks in public among the Latins with great success, and one of his current teachers is a Greek, who managed to get a chair at a Latin university (Jacob of Modon?), which Kalekas regards as a great achievement. $^{335}$

Although the epistle in question omits certain critical details, most importantly the identities of the addressee and his Greek teacher in a Northern Italian university, it provides information of a different nature. Raymond-Joseph Loenertz, the editor of the letter-corpus of Kalekas, interpreted the statement on the former student speaking in public at the city of his university as a clear reference to preaching to the local population, ${ }^{336}$ which points to Catholic theological studies on his behalf. Loenertz also suggested that the unnamed teacher of Greek origin mentioned in the letter can be identical with Jacob of Modon, a Greek who became a Catholic cleric and was the protector of Uberto Decembrio, the famous humanist and chancellor of Gian Galeazzo Visconti, the first duke of Milan. ${ }^{337}$

The fact that Kalekas explicitly praises Greek converts of Catholicism and their religious activities is most logical as he himself joined the Catholic Church in 1396 and even entered a Dominican monastery in Mytilene in $1403 .{ }^{338}$ In the light of these biographical events, there is a good reason to suppose that Kalekas wrote honestly in his letter, when he described his fellow converted Byzantines. In his letter, the young Greek cleric is presented as a talented young intellectual, who is already adept in Catholic theology, which is implicitly understood as 'correct'. What is more, he is shown to be fluent enough in the local Italian dialect to preach to the local citizens, and does that regularly, guiding to salvation many souls, so working for a noble aim.

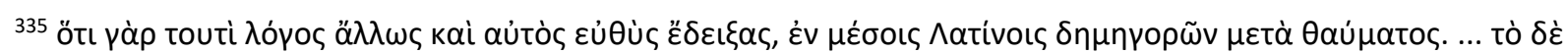

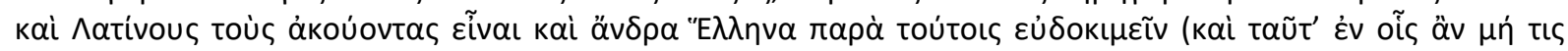

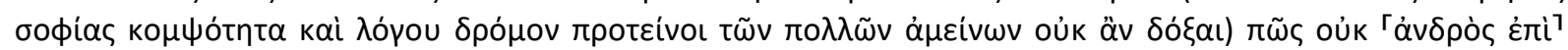

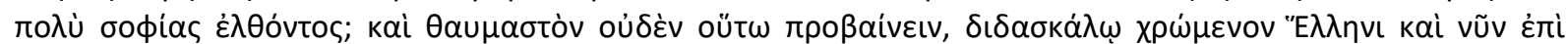

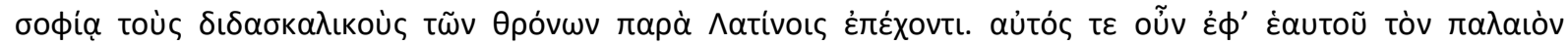

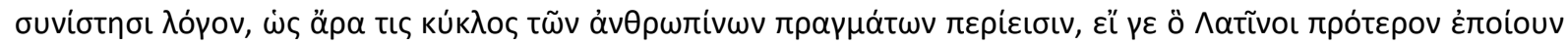

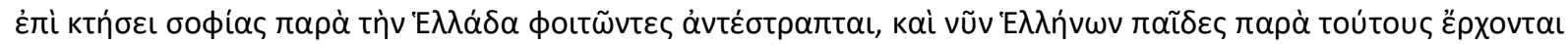

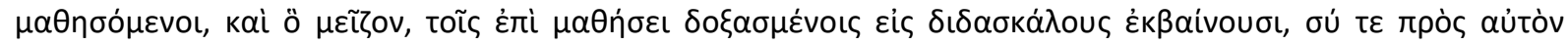

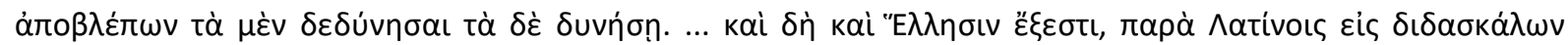

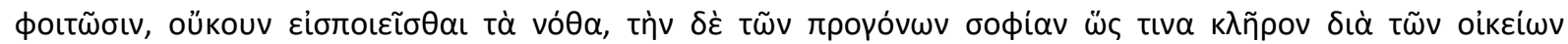
картоо̃ $Ө \alpha$. In LOENERTZ 1950, pp. 268-269.

${ }^{336}$ LOENERTZ 1950, p. 142.

337 LOENERTZ 1950, p. 40.

${ }^{338}$ GeanAKoplos, Deno John: Western Influence on Byzantium in Theology and Classical Latin Literature. In Geanakoplos, Deno John: The Interaction of the 'Sibling' Byzantine and Western Cultures in the Middle Ages and the Italian Renaissance (330-1600) New Haven and London, Yale University Press, 1976, pp. 95-117, pp. 106-107.
} 
After depicting this noble character, Kalekas portrays one of those who instruct this guide himself, another catholicised Greek, who even became a university professor of Catholic theology, requiring hard work and talent in itself, and enhanced by the value that Kalekas attributes to Catholic teachings. The two intertwined cases are presented as two connected success stories, in which talented and righteous persons triumph over difficulties, accepting the 'true faith' and building well-deserved, remarkable careers.

The remarks of the author also have cultural implications, as he defines being wellversed in Western culture as an honourable trait and achieving a chair in a Western university as a remarkable achievement. These evaluations presume a positive understanding of 'Latin' erudition, regarding it as developed, useful and commanding respect, which is in a striking contrast to its traditional, condescending Byzantine image.

\section{V.11. The Charge of the Cultural Decline of the Greeks}

The effects of Latin cultural influence on Byzantines were not held equivocally in high regards., In a letter from 1401-1402, sent from Italy and addressed to Manuel Raoul, Manuel Kalekas attempts to explain to his addressee, why he chose to travel to Italy instead of Cyprus. First of all, he was disturbed by the fact that everyone except Raoul became barbarised there, but another reason was that those who very strongly favoured the division of divinity instead of the new theology of them [Kalekas and Raoul] and held almost it [the aforementioned theology condemned by Kalekas] in higher esteem than the apostolic teachings, and those lest, figuring out [the theological views of Kalekas] and being [spiritually] diseased in regard of these [teachings] prepare for hate [against Kalekas].

He continues with the comment that it is necessary for the evil ones of the people to exaggerate these [the views of Kalekas], and to order that those who worship the Son as equal to the Father should not to be even regarded as Christians. Finally, Raoul has failed to convince the king to grant any status to Kalekas in case he moves to Cyprus. Later on, Kalekas also states that he thinks it will seem precious to Raoul, who moved away from his homeland to the barbarians a long time ago, that they [Kalekas and Raoul] will have a conversation in Greek from Italy. ${ }^{339}$

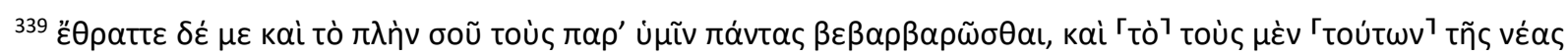

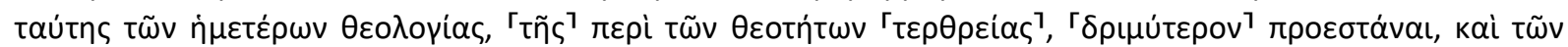

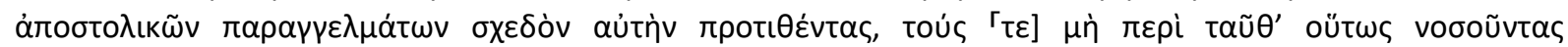

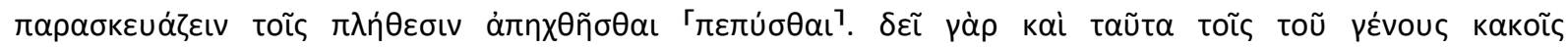


The euphemistic reference to the 'new theology' of Kalekas and Raoul clearly means the Catholic faith, to which both of them converted, while the division of divinity is an allusion to hesychasm, the official theology of the contemporary Orthodox Church. As Roman Catholicism and Palamite Orthodoxy strongly condemned each other, and the latter was the dominant denomination on the island of Cyprus, being the creed of the Greek majority, heavily oppressed by the local Catholic Frankish élite, strong hatred against a Greek convert to Catholicism among the Greek Cypriot was definitely a realistic problem.

However, as the Orthodox majority was under strong control of the Catholic minority, suffering attacks for being a Catholic was not a very probable possibility. ${ }^{340}$ Naturally, as Raoul failed to achieve any promises of a status by the king (chronologically Janus de Lusignan, 1398-1432), moving to the island would have logically meant closer contacts with the local Greeks than as a court scholar, which would have meant more experiences of rejection by them.

The comment on the evil ones exaggerating Catholic beliefs that differ from the Orthodox ones is a rather ironical judgment on Palamites and their theological views. It presupposes the existence of two groups within the Orthodox community which accepted hesychasm, a minority, identifiable with the Orthodox clergy, that is able to correctly judge the aforementioned Catholic teachings, but is so hostile to them that it exaggerates these dogmas to depict them as hateful beliefs, and a majority, identifiable with the common people, who are far too ignorant to assess such theological nuances, and are under the influence of their Palamite clerics, who mislead and instigate them to violence. The impression is very far from flattering, portraying the Cypriot Greek Orthodox believers as a mélange of the deceitful, malevolent clergy and the ignorant, utterly misguided common people, who are prone to turn into a violent, fanatic mob, befitting the charge that they became barbarised.

It is worth noting that the charge of hesychast theologians deliberately exaggerating Latin beliefs to portray them as condemnable views, is rather similar to the criticism voiced by the teacher and friend of Kalekas, Demetrios Kydones, a fellow convert to Catholicism in

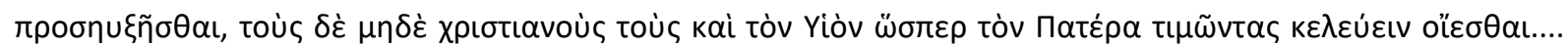

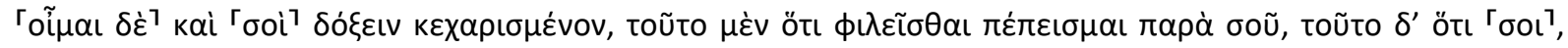

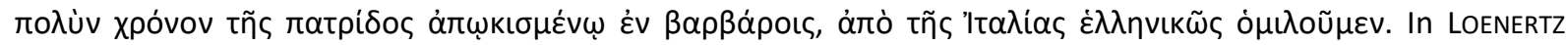
1950, p. 278.

340 For the relationships between the two major denominations on Lusignan Cyprus, see GILL, Joseph: The Tribulations of the Greek Church in Cyprus 1196-c. 1280. Byzantinische Forschungen V (1977), pp. 73-93, pp. 89-90; ASDRACHA 1994, pp. 88-89 and COUREAS 2015, pp. 146-148. 
his Apologia I, ca. $1363,{ }^{341}$ in which he expounds that hesychast theologians do not find anything fallible within Catholic dogmas, but they still ardently, and irrationally, despise them, so they keep disparaging these teachings. ${ }^{342}$

It is also remarkable to take a closer look at the euphemisms used by Kalekas to his own Catholic creed and to Palamite Orthodoxy. Both of these are subjects to a serious reduction to one of their core beliefs, which are expressed in seemingly obscurant, yet, for the educated Byzantine contemporaries, completely clear descriptions. In the case of Catholicism, this core tenet is the Filioque, the belief that the Holy Spirit originates from both the Father and the Son and is described as the equal worship of the Father and the Son.

This argument was expounded in more detailed versions earlier by Demetrios Kydones and became a common argument against the standard Orthodox criticism of the Filioque, as it portrays the Catholic dogma in question as a teaching compatible with the Orthodox understanding of the Holy Trinity, although it is not an accurate interpretation of it. The reason behind this solution is that Kydones understood this doctrine as the central theological difference between the Catholic and the Orthodox Churches, supporting their Union on the basis of the Catholic point of view, but saw that the Filioque was hardly compatible with the Orthodox understanding of the Trinity. Therefore, he went at great lengths in order to prove the validity of the Filioque. ${ }^{343}$ Kalekas himself was similarly very interested in this theological problem, composing a florilegium on the subject, ${ }^{344}$ beside of being a friend and student of Kydones, so the presence of this argument in this context does not come as a surprise.

On the other hand, Palamism appears as the division of divinity, which refers to one of the central theological views of Gregory Palamas, the distinction between God and his uncreated, eternal energies, through which God interacts with the world, and with which human beings can commune, thus serving with a coherent understanding of deification without violating previously established Orthodox teachings. ${ }^{345}$ The condemning description

\footnotetext{
${ }^{341}$ RYDER, Judith T.: Byzantium and the West in the 1360s: The Kydones Version. In HARRIS, Jonathan - HoLMES, CATHERINe - RUSSELL, Eugenia: Byzantines, Latins, and Turks in the Eastern Mediterranean World after 1150. Oxford University Press, 2012. pp. 345-366, p. 351.

342 RYDER, Judith R.: The Career and Writings of Demetrius Kydones. A Study of Fourteenth-Century Byzantine Politics, Religion and Society. Leiden - Boston, Brill, 2010, pp. 90-92. Henceforth RYDER 2010.

${ }^{343}$ RYDER, Judith R.: Catholics in the Byzantine Political Elite: The Case of Demetrius Cydones. In LAMBERT, Sarah NiCHOLSON, Helen (Eds.): Languages of Love and Hate: Conflict, Communication and Identity in the Medieval Mediterranean. Brepols, Turnhout, 2012, pp. 159-174, pp. 163-166. Henceforth RYDER 2012.

${ }^{344}$ GoulLLARD, Jean: Les influences latines dans l'oeuvre théologique de Manuel Calécas. In Échos d'Orient, tome 37, $\mathrm{n}^{\circ}$ 189-190 (1938), pp. 36-52, pp. 38-40.

${ }^{345}$ For a detailed, yet concise summary of the teachings of Palamas regarding the essence and uncreated energies of God, see MEYENDORFF, John: The Holy Trinity in Palamite Theology. In FAHEY, Michael A. -
} 
of it as being the division of divinity echoes a standard criticism of this Palamite belief, of which an early proponent was once again Demetrios Kydones in his Apologia III. Kydones described the views of Palamas as a separation of the ovoría, that is, the essence of God and his attributes (for instance, his benevolence), and judged it as completely false. ${ }^{346}$

Nevertheless, for the subject of this chapter, the cultural reference is the most important, namely that, according to Kalekas, everybody has become a barbarian on the island except for Raoul. This statement most probably should be understood as an exaggerated expression of the despise felt by Kalekas upon the circumstance that the intellectual niveau among the Greek-speaking Cypriots was rather low, and very few of them knew Classical Greek culture or even Classical Greek. It seems to be a surprisingly rigid identification of being a 'civilised Roman' with Classical education and the knowledge of Classical Greek, as these two skills were definitely beyond the scope of most of the Greek-speaking population in the entire Middle Ages. The verdict was probably not independent of the hostile attitude of the Greek-speaking Cypriots towards his Catholic faith.

Curiously, Kalekas does not explain the relationship between the Latins inhabiting Cyprus and barbarism. Regarding the Byzantine tradition, they could and should be defined as par excellence barbarians, but Kalekas questioned the traditional Byzantine image of Westerners, as it is demonstrated by his conversion to Roman Catholicism and his remarks praising Latin erudition in certain other letters. However, he was ready to call them barbarians in his letter to his friend, Maximos Chrysoberges, criticising Milanese expansionist attempts

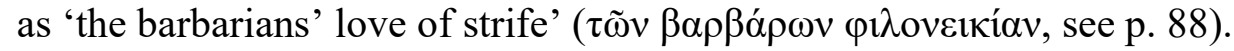

These elements together imply a rather interesting interpretation of barbarism by Kalekas, in which uneducated Byzantines can be defined as barbarians, while erudite Westerners fell outside this category. In this model, a rigid, traditional boundary between Byzantines and all other ethnic groups, which was determined by ethnicity, religious adherence, and culture at the same time, becomes a product of cultural niveau and religion, and permeable to both directions. Therefore, the uneducated Byzantines on Cyprus can count as barbarians just like the inerudite local Franks, while local Western humanists and Raoul could probably be understood as members of the same community of 'civilised persons'. And responsibility for their sorry 'barbarian' state is attributed mainly to the local Byzantines themselves, with special respect to their clergy.

MeYendoRfF, John: Trinitarian Theology East and West. St. Thomas Aquinas - St. Gregory Palamas. Holy Cross Orthodox Press, 1979. pp. 25-43, pp. 30-35. Henceforth MEYENDORFF 1979.

${ }^{346}$ RYDER 2010, pp. 124-125. 
An interesting parallel to the views of Kalekas on barbarisation comes from Ioannes Chortasmenos, who, in his letter to Demetrios Maurianos, a commander of the imperial fleet, asks the addressee, to get to know the habits of the people, while he fares the sea among different islands, on each of them [of the islands], which were taken by the Latin greed, whether they [the local people] have not become entirely wild and have forgotten the Greek language. ${ }^{347}$ Both views seem to suppose a certain connection between the acquisition of Byzantine territories by the Latins and the 'barbarisation' of the local Greek-speaking population, but local Greek dialects must had been very far from Atticizing intellectual norms even before the Western conquests and it is untenable to suppose that high-level learning completely ended with the arrival of the new, Catholic élites, even if it became less common for various reasons, e. g. economic decline. ${ }^{348}$

The explanation seems to lie with the, from the Byzantine point of view negatively, changed status of Greek learning, and its consequential decline, in many territories after they were conquered by the Latins, and the phenomenon that the language of the Greek people under Catholic rule begun to show characteristic Western effects, ${ }^{349}$ which was hardly desirable from a culturally purist Byzantine intellectual point of view. Thus, the abhorrent image of general cultural degradation suggested by the words of Chortasmenos is basically a reiteration of erudite Byzantine stereotypes on the consequences of Latin rule.

However, this stereotype says very much about the perception of differences between the Byzantines and the Latins. According to that, the Greek-speaking populations of the islands conquered by the Latins have faced with such cultural degradation that even they turned completely 'wild' and lost any knowledge of the Greek language, which can be identified with its language register used by an educated Byzantine like Chortasmenos.

The source of this degradation is clearly the Latin rule that suggests that Westerners have simply brought their Byzantine subjects to their own cultural level, perceived as extremely low by the claims about them turning wild. The claims of Chortasmenos implicitly suggest a large civilisational gap between the Byzantines and the Westerners, regarding the Byzantines as culturally superior ones.

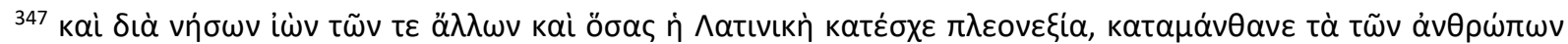

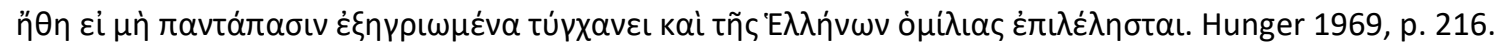

${ }^{348}$ For a demonstration of impoverishment on the smaller Greek islands, see, for instance, LUTTRELL, Anthony T.: The Latins and Life on the Smaller Aegean Islands, 1204-1453. In ARBEL, Benjamin - HAMILTON, Bernard - JACOBY, David (Eds.): Latins and Greeks in the Eastern Mediterranean After 1204. London, Frank Cass, 1989, pp. 146157, pp. 152-153.

${ }^{349}$ For a demonstration of this phenomenon on the Cypriot example, see ASDRACHA 1994, pp. 91-92.
} 


\section{V.12. Conclusion}

The analysed letters display various aspects of culture, connected to different judgments voiced by their authors. First of all, reminiscences of the Latin Roman past of Byzantium appear in certain allusions, to poetic genres and denominations of money, showing the survival of certain elements of Latin erudition even centuries after Greek became the official language of the Empire, replacing Latin in this function. Nevertheless, most of the opinions preserved in the sources refer to 'Latin' culture understood as 'Western' culture, in its forms contemporary to the letters, and perceived as not part of the living tradition of the Byzantines, either as a part of 'Roman heritage' recovered through the West, or as a display of Latin 'barbarism'.

Among these references, certain ones discuss aspects of Latin culture especially material in their nature, that is, garment and food, details that are easily discernible even without experiencing more abstract elements of a civilisation. In the great majority of cases, however, the letters deal with these intangible cultural characteristics, and most of their judgments can be incorporated into categories mirroring each other. The image of Latin barbarians looting a Greek library to sell the books or merely destroy them can be paralleled with the charge that cultural decline turned masses of everyday Byzantines into barbarians. Similarly, gestures of Westerners receiving a Greek paideia are mirrored by a Byzantine discovery of Latin education. The only category remaining without a counterpart in the letters is Western admiration of Greek intellectuals, as Greek fondness for Latin scholars is not portrayed in the examined sources.

In strong connection to the nature of the aforementioned categories, the references to Western culture tend to represent two types of opinion, definite contempt and definite sympathy. These views presented in the sources mostly fit the general attitudes of the different authors towards the Latins, being negative in the letters of those who condemned Westerners and positive in the epistles of those who sympathised with the Latins. 


\section{Religious Subjects Occasionally Present in the Letters}

Certain presentations of the beliefs and practices of the Latins do not fit into the categories defined by the aspects of Catholic religiosity commonly addressed in the analysed sources. This chapter deals with these peculiar comments on Western faith and religious behaviour.

\section{VI.1. Heresy}

One of Nikephoros Gregoras' letters, sent from Constantinople to Thessalonike, addressed to Maximos, hieromonakhos of the Khortaites monastery, ${ }^{350}$ contains a most interesting condemnation. After stating that he prefers Sokrates to Pythagoras of Samos, Gregoras expounds his reasons for that. He claims that while Sokrates remained in Athens and his tongue and deeds proved to be useful for his fellow Athenians, Pythagoras left his homeland for Italy, to become the leader of the Italian heresy for the epochs coming. ${ }^{351}$ The exact same accusation appears in a different version of this letter. ${ }^{352}$

One of the main subjects in the letter is love towards the fatherland, and the examples of Sokrates and Pythagoras are connected to that, with the clear intent of supporting the argument of Gregoras on the importance of attachment to one's homeland. The condemnation of the deeds of Pythagoras becomes the more interesting as another letter of Gregoras to Maximos (letter 21 in the edition of Leone) cites the ancient Samian philosopher as an example of those who glorified their fatherland with their notable achievements, mentioning him together with Orpheus, Lykourgos and Minos. ${ }^{353}$ This circumstance raises doubt about the sincerity of both judgements expressed by Gregoras.

However, these contradictory claims about Pythagoras fit well into an ambivalent Christian attitude towards the Samian philosopher, dating back to Late Antiquity. As the history of philosophy can reconstruct it, reports on Pythagoreanism, from the earliest Platonic

\footnotetext{
350 PLP 16048.

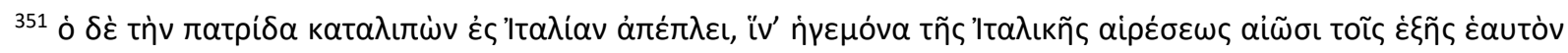
$\pi \alpha \rho \alpha \theta \varepsilon i n$. In LEONE 1982, p. 63.

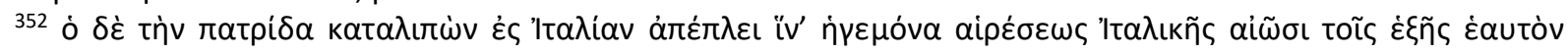
$\pi \alpha \rho \alpha \theta \varepsilon i ́ n$. In LEONE, 1982, p. 66.

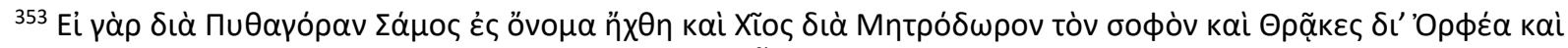

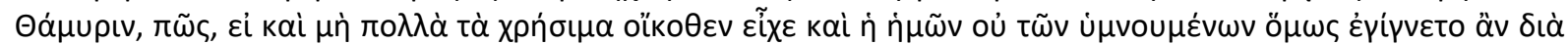

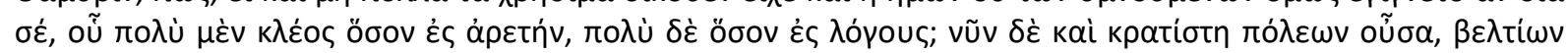

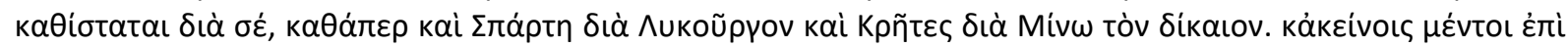

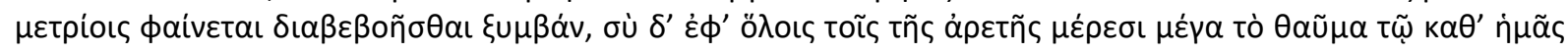

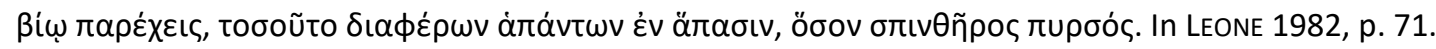


remarks, differentiated two currents within that philosophical tradition, a scientific and a religious one. Pythagorean scientific and religious views attracted very different evaluations from non-Christian interpreters, very often keeping Pythagorean science in high regard, while tending to be rather critical towards the religious doctrines of the movement and finding it explicitly difficult to reconcile these two currents.

Early Christianity inherited much of this deep ambivalence through the Greco-Roman philosophical paideia it absorbed and modified it under the influence of the perceived accords and differences between Pythagorean and Christian doctrines, which views then were inherited by Byzantine thought. ${ }^{354}$ Therefore, for a Byzantine intellectual, like Gregoras, Pythagoreanism was a multifaceted school. Albeit he does not concretise the issues he relies on when forming his opinion, the aforementioned tradition and the claim about Pythagoras being a founder of the 'Italian heresy', suggests that he found Pythagorean religious tenets, e. g. the transmigration of souls, appalling as a faithful Christian. However, scientific views attributed to Pythagoreanism, for instance, its numerology and theory of harmony, could seem to him convincing and remarkable.

It is clear that Gregoras understands the religious aspects of Pythagorean thought under the expression of 'Italian heresy' ( $\alpha i \rho \varepsilon ́ \sigma \varepsilon \omega \varsigma$ 'I $\tau \alpha \lambda \imath \kappa \tilde{\eta} \varsigma$ ). The ethnonym Italian misrepresents the circumstance that the beliefs of Pythagoras began to spread among the Greek-speaking population of Southern Italy and Sicily, albeit it is geographically accurate. Moreover, heresy is a rather interesting expression for a non-Christian belief system, as it suggests a version of Christianity regarded as incorrect by another Christian denomination.

Their combined effect is a blurred boundary between the Greek believers of Pythagoreanism inhabiting Ancient Italy and the Roman Catholic Italian contemporaries of Gregoras, while concealing the Greek ethnicity of the former group. Whereas it is far from certain, it is possibly a deliberate solution, suggesting the inhabitants of Italy having a long tradition with adherence to 'erroneous' religious views. Meanwhile, Byzantine Orthodoxy serves as an implicit standard of 'correct' beliefs, stressing a large religious difference between Italians and Byzantines.

Heresy is not only represented as a characteristic of Westerners in the previous letter, written by Gregoras. In his Epistula encyclica contra Graeco-Latinos et decretum synodi Florentinae, Markos Eugenikos recalls the other camp's statement, according to which, the

${ }^{354}$ CELEnZA, Christopher S.: Piety and Pythagoras in Christian Florence. The Symbolum Nesianum. Bast, Robert J. (Ed.): Studies in the History of Christian Thought Cl. Brill, Leiden - Boston - Köln, 2001, pp. 4-10. 
Latins are not heretics, only schismatics, suggesting that the two categories are not very different. ${ }^{355}$ As he says, if the Latin views would not differ from the Orthodoxy, it would be in vain to punish them. ${ }^{356} \mathrm{He}$ says that the Latins are all heretics, so their supporters are heretics too. ${ }^{357}$

Markos Eugenikos here basically repeats his argument used during the sessions of the Council of Ferrara-Florence discussing the Filioque, where he claimed that the Latins were not merely schismatics, alleged by the pro-Unionist Orthodox theologians, but in fact heretics. He saw that as the exact reason behind the schism between the two churches and explained the fact that the Orthodox Church did not brand the Catholics as heretics with its remarkable prudence.

The outcome at the council was far from positive for Markos Eugenikos, as Basilios Bessarion stated that it would mean that a great number of saints and fathers were heretics according to their own writings, and Eugenikos did not find a better counterargument than the claim that the writings of saints and fathers may be tampered with in order to produce evidence for the Catholic theological stance. Bessarion replied that after a dismissal of all the texts doubted on such a basis by Eugenikos, there would be mainly blank pages in theological books. ${ }^{358}$

The main reason behind the fact that Markos Eugenikos produced such a questionable argument referring to possible falsifications was the fact that it was an axiom for all the Orthodox theologians that the saints cannot contradict each other about the Christian faith, because all of them were inspired by the Holy Spirit. To suppose that the saints may contradict each other would have been tantamount to suppose that the Holy Spirit contradicted itself or even misguided certain unfortunate saints. ${ }^{359}$

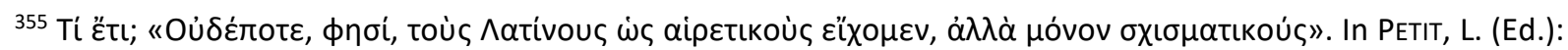
Documents relatifs au concile de Florence. II Oeuvres anticonciliaire de Marc d'Ephese. Documents VII-XXIV. (Patrologia Orientalis XVII 2 Nr. 83) Paris 1923 (Reprint Turnhout 1974), p. 452.

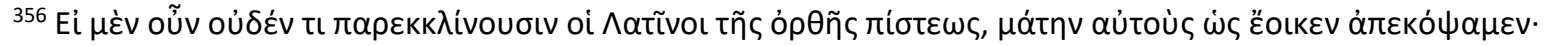
PETIT 1923, p. 452.

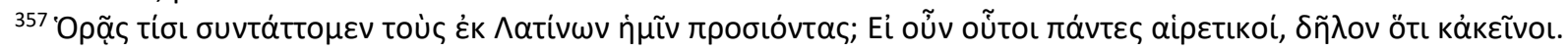
PETIT 1923, p. 453.

358 The above-mentioned clash between Bessarion and Eugenikos, described by Sylvestros Syropoulos in detail in his work on the council (LAURENT, Vitalien (Ed.): Les "Mémoires » du Grand Ecclésiarque de l'Église de Constantinople Sylvestre Syropoulos sur le concile de Florence (1438-1439), Paris, Centre National de Recherche Scientifique, 1971, pp. 232-235), is summarised in GILL, Joseph: Le concile de Florence. Desclée \& Co., Tournai, Belgium (originally published in English under the title 'The Council of Florence' Cambridge University Press, 1959), pp. 214-215. Henceforth GILL 1959.

359 GILL, Joseph: Agreement on the Filioque. In GILL, Joseph: Personalities of the Council of Florence. Blackwell, Oxford, 1964, pp. 254-263, pp. 256-257.
} 
These circumstances left a rather limited space for Eugenikos to manoeuvre, and his debacle may contribute to the fact that in his Encyclica he does not mention any contradicting evidence to the perceived 'heresy' of the Catholic Latins, treating it as a bare fact that they are heretics. As the author leaves no doubt that he regards Orthodoxy as the only 'correct' form of Christianity, the religious difference between its Byzantine adherents and the Latins logically has to be dramatic.

Furthermore, he is unhesitant to tread one step further and state that this 'fact' makes any Orthodox who supports the Union similarly a heretic due to the adherence to heretic beliefs. It means that the religious boundary does not coincide with the ethnic boundary between the Byzantines and the Latins, but lies within the Byzantine community, separating Unionists from anti-Unionists just like the latter group from the Catholic Latins, while defining both Unionist Byzantines and Catholic Latins as heretics. To conclude, the claims of Markos Eugenikos are less about precise argumentation and more about an ex cathedra condemnation of any alleged theological error and even about instigation against Catholic Westerners and Unionist Orthodox believers.

\section{VI.2. Religious Innovation}

Another religious subject that appears occasionally in the analysed letters is alleged Western religious innovation. In a letter addressed to Nikephoros Gregoras, Gregorios Akindynos portrays himself as a faithful Orthodox, openly fighting against both the 'polytheism' of Gregorios Palamas and the 'new-fangled speech' of the Latins. ${ }^{360}$ First of all, to understand these remarks, it is important to be aware of the circumstances in which the letter was written. The letter, dated to the spring of 1345 by Constantinides Hero, was composed as an answer to Nikephoros Gregoras, after Akindynos, at the suggestion of Georgios Lapithes, ${ }^{361}$ had requested Gregoras to accept the leadership of the anti-Palamite Orthodox group, but he reacted with repeating the criticism of Lapithes, earlier expressed by Gregorios Palamas himself. ${ }^{362}$

Besides expressing his deep trust in Lapithes, Akindynos also expounds his own ideological position, describing himself as a faithful protector of traditional Orthodoxy and an

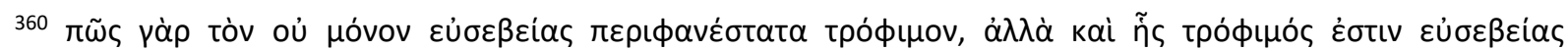

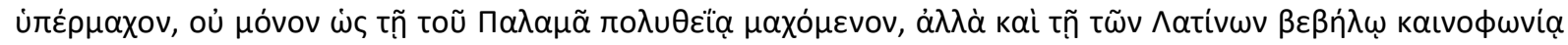
$\pi \alpha \rho^{\prime}$ óvtıvoũv; In CONSTANTINIDES-HERO 1983 p. 190. (44th letter)

${ }^{361}$ For the person of Georgios Lapithes, an influential Cypriot anti-Palamite Orthodox, see PLP 14479.

362 Constantinides-Hero, 1983, p. 381.
} 
opponent of any dogmatic alterations to Christianity, defining Catholicism and Palamism as regrettable examples of this wrong practice, explicitly rejecting both of them. Two important arguments, cited by Akindynos to validate his own opinion, are the support of all the Orthodox patriarchs, a wide support of international Orthodox communities, and the story mentioned earlier, according to which Palamas tried to convince the Genoese of Pera and the Order of Saint John of his right in vain, and they even ridiculed Palamite teachings.

This utilisation of the Latins as a device to disparage Palamas and his followers features Catholics as people who display religious errors, but their views are still less distant from Orthodoxy than Palamism is, and they stand above Palamites, appearing as 'acceptable' in a clear contrast to the adherents of Hesychasm. A similar phenomenon is present in the statement of Akindynos in the same letter, just mentioned above. Palamism is depicted as 'polytheism', with an intentionally false description of its tenets regarding the difference between the essence of God and his uncreated energies ${ }^{363}$ to connect it to paganism, portrayed as utterly incompatible with Orthodoxy.

However, Catholicism, while it receives criticism, is presented as mainly 'erring' with its innovative theological vocabulary. Under this vastly different levels of 'error' could be understood, circumscribing and by that downplaying the differences between Catholicism and the traditional Orthodoxy confessed by both Akindynos and Gregoras, while being explicitly critical to Latin religious views at the same time. This careful, tactical argumentation is most probably not independent of the support provided by Latin states, like Genoa and the Order of Saint John, to the anti-Palamite regency seated in Constantinople during the civil war of 1341-1347, of which government Akindynos was a high-profile sympathiser. ${ }^{364}$

A few generations later, Ioannes Eugenikos voiced far less conciliatory tones. In a letter, written to Loukas Notaras, he urges the mesazon to turn against Patriarch Gregory, who supported the Union of Florence, and to convince as many Orthodox who fell into 'error' and accepted the Union as possible. Emperor John VIII is heavily condemned by Eugenikos for his friendly attitudes towards 'Latinizers' and for his acceptance of the union, the latter

\footnotetext{
${ }^{363}$ For a brief summary of Palamite teachings on these topics, see MEYENDORFF 1979, pp. 30-35.

${ }^{364}$ A short summary of the involvement of Akindynos in the Hesychast Controversy is provided by PAPADAKIS, Aristeides: The Christian East and the Rise of the Papacy: The Church 1071-1453. New York, Crestwood, 1994, pp. 290-293.
} 
interpreted as an exchange for support against the Ottoman Empire by the author. Eugenikos also condemns Latin 'innovations.' 365

It is worth remarking that Notaras was portrayed in the historical work of Doukas as a stalwart anti-Unionist, and Doukas even attributed to him an infamous statement about his alleged preference of the turban of the Ottoman sultan to the tiara of the Pope, influencing the popular image of the mesazon until today. However, the surviving evidence questions this image of the late intermediary of John VIII.

Although Notaras, in spite of his important position, did not participate either in the Council of Ferrara-Florence, or in the Council of Basel, yet he carried out the Unionist policies of John VIII in Constantinople loyally and accurately, attempting to placate the antiUnionist leaders Ioannes Eugenikos and Georgios-Gennadios Scholarios in vain, instead of acting in accordance with the wishes expounded by Eugenikos in his letter in question. ${ }^{366}$ This behaviour suggests that Notaras was far from being an ardent anti-Catholic as he was portrayed by Doukas. What is more, the letter of Eugenikos did not aim to instruct a loyal supporter on actions necessary to further the anti-Unionist cause, but he rather attempted to convince him to join the ranks of the Orthodox resistance. ${ }^{367}$

The presentation by Eugenikos deserves further examination. It is important to note that John VIII is criticised, but Notaras is not urged to turn against him, in clear contrast to the action suggested against the patriarch Gregory. In addition to this, the sympathies displayed by the emperor toward the pro-Latin camp are explained with his desperate attempt to gather support from Catholic realms against the Ottoman threat. Eugenikos does not question the authority of his ruler and argues that the deeds of his imperial majesty condemned by the antiUnionist camp have their roots in his benevolent, yet misguided effort to aid his empire and people.

Thus, Ioannes Eugenikos heavily downplays any possible responsibility of John VIII for the perceived negative results of his ecclesiastical policies, stressing his good intent and the foul deception the emperor became a victim of. This is hardly a mere coincidence; any instigation of the mesazon to turn against the legitimate emperor, raising doubt to his right to

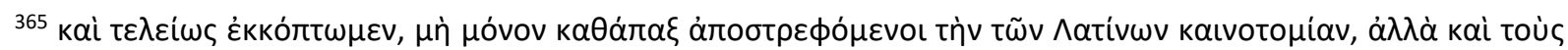

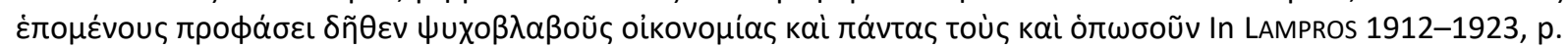
187.

366 GILL 1959 pp. 335-336; MATSCHKE, Klaus-Peter: The Notaras Family and Its Italian Connections. DOP 49 (1992), pp. 59-72, pp. 66-67. Henceforth MATSCHKE 1992.

${ }^{367}$ For a short description of this letter of loannes Eugenikos in the context of his anti-Unionist propaganda, see TSIRPANLIS, Constantine, N: Mark Eugenicus and the Council of Florence. A Historical-Re-evaluation of His Personality. Unpublished doctoral dissertation, Fordham University, 1973 pp. 90-91.
} 
exercise his imperial powers or explaining his church policies as intentionally harmful would had been tantamount to high treason, endangering the very life of Ioannes Eugenikos and seriously harming his cause. Regardless of his true opinion, which is not decipherable from this letter, it was the furthest he could go in criticising the policies of the acting Byzantine government without becoming a rebel against the emperor. ${ }^{368}$

The opposition of Catholicism displayed by Eugenikos and his supporters is justified both by the religious 'error' and its disastrous consequences, with one brief sentence. Catholicism is depicted as guilty in religious 'innovation', which leads to the 'harm of [its adherents'] souls'. The charge of innovation measures Catholicism to the tacitly present Orthodox beliefs, which are understood as 'correct' by the author, so the two denominations could hardly differ more in this interpretation. It also means that their respective adherents, the Latins and the Unionist Byzantines, and, respectively, the anti-Unionist Byzantines, differ pronouncedly in the field of religion.

It is also important that this innovation is not simply portrayed as 'erroneous' but as harming souls. It suggests that the ultimate outcome of being a Catholic is eternal damnation, widening the perceived chasm between Catholicism and Orthodoxy and their adherents even further, with the clear intent of soaring fear and the sense of a moral obligation to oppose this innovation and the faith behind it. This effect is enhanced by the request to Notaras to convince as many Unionists of their 'error' as possible, understood as 'help' given to those referred by Eugenikos, which portrays this hoped activity as a quasi-'aid mission'.

Markos Eugenikos, the older brother of Ioannes, proved similarly critical of Latin innovation. Writing to the monks of the Vatopedi monastery at Athos, he admonished his audience to avoid those who want to introduce and entrench Latin innovation. ${ }^{369}$ This warning has wider implications than merely commanding the monks of Vatopedi to avoid contact with Catholics and Unionists. As he saw those, who followed Catholic teachings as heretics, corroborated by his use of the word 'innovations', he most probably expects the traditional behaviour of Christian believers from the Athonite monks, i.e. excommunication.

It is not the canonical sanction applied by the official church what is meant here by the word excommunication, but the obligation to pious Christians to avoid any contact with persons perceived as heretics, as, according to the canon law of the Orthodox Church, heresy

\footnotetext{
368 For a brief summary on imperial legitimacy, see, for CHEYNET, Jean-Claude: Pouvoir et Contestations à Byzance. Série Byzantina Sorbonensia 9. Paris, Publications de la Sorbonne, 1990, pp. 184-190.

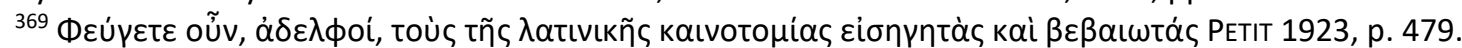


is a sin that automatically severs the bound between the Church and the heretic and its sanctions automatically come into power, even before a formal court verdict was given (poenae latae sententiae), including that all faithful Christians being aware of the sin committed should answer with the complete rejection of the heretic. ${ }^{370}$

Eugenikos brands his Catholic Latin and Unionist Byzantine opponents as heretics in an implicit, but, for his audience, obvious way, certainly counting on the traditional anti-Latin attitudes of the Athonite monastic communities and their awareness of the behaviour expected towards heretics by the canons of the Orthodox Church. The standard of 'correct' belief defining heresy is naturally the Orthodox faith, and the supposed precipice between it and Catholicism is understood as very wide, evidently favouring the Orthodoxy.

The context, especially the circumstance that the dreaded introducers of Latin innovation had to be mainly Byzantines, also makes it clear that the religious boundary is not strictly bound to the ethnic one. The innovation is clearly Latin regarding its origins, but its adherents are not necessarily Westerners, so the boundary divides the Byzantine ethnic community.

However, Markos Eugenikos has also left behind far more dramatic remarks on Latin innovation than the one discussed above. In a letter, written to Georgios-Gennadios Scholarios, he warns the addressee to consider that, if he remains silent against the Union of Florence, he will descend to Hades after his death, leaving behind everything he cares so much in this world. And there, he will be judged accurately for what is erroneously called a synod (the council of Ferrara-Florence), for the blasphemous teaching of the Filioque and for the souls lost because of this teaching, which latter remarks I will analyse in detail in the chapter on Filioque.

However, after that, Markos Eugenikos continues the enumeration of possible sins that would lead to a terrible judgment on Scholarios in the afterlife. There will be judgment on those who go under (with other words, who accept) the lawless and ridiculous habits of the Latins and those who draw upon their own heads the curses and anathemata of the innovation of the faith. ${ }^{371}$ These seemingly rather vague statements prove rather talkative in reality. First of all, the Latin habits are described as contradictory to the law, which suggests that their content is sinful and amoral, especially if the divine law of the Scripture is understood as the 'law' that they contradict.

\footnotetext{
370 HeRman, E.: Hat die Byzantinische Kirche von selbst eintretende Strafen (poenae latae sententiae) gekannt? BZ 44 (1951), pp. 258-264, pp. 260-262.

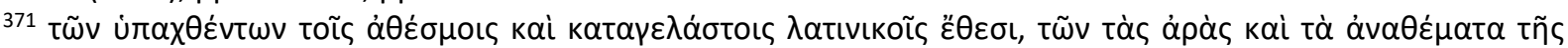

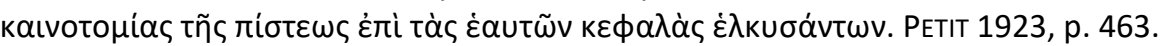


Second, the Catholic habits are branded as 'ridiculous' ones. It invokes the images of illogical actions and nonsensical behaviour, which are not alien to the general Byzantine views on Latin habits. It is worth noting that the concepts of logic and law are closely associated with each other, which led to a potential of the images of contradiction to logic and contradiction to law enhancing the effects of each other in the mind of the audience.

These characteristics have to be understood in comparison with an unmentioned, yet tacitly present and infallible Orthodoxy, which interpretation establishes a great difference between the two denominations. The same stands for their Byzantine and Latin adherents, who are in a striking contrast regarding the field of religion, without any doubt of a far higher Byzantine status in this respect, relying on the lines of Eugenikos.

Furthermore, innovation of doctrines appears with its curses and anathemata that certain unfortunate sinners draw upon their own heads. Curses and anathemata are not merely powerful terms; they had been associated with innovation for centuries in the time of Markos Eugenikos. Anathema, this ecclesiastical punishment more solemn than excommunication, had been a standard sanction against heretics, while the term, understood as 'malediction', was very often accompanied by the curses of the 318 fathers of the Council of Nikaia as a sanction in Byzantine deeds. ${ }^{372}$ The prediction of judgments for these 'sins', especially combined with the aforementioned idea of judgments for the adoption of the Filioque and its consequences for the salvation of masses of believers, served as a potent device of inciting fear in Scholarios and the possible audience.

Nevertheless, Gennadios Scholarios proved that he was perfectly capable of creating dramatic depictions of the allegedly devastating consequences of Latin innovation. In his socalled $2^{\text {nd }}$ letter against the Union of Florence, addressed to the megas doux Loukas Notaras, in $1452,{ }^{373}$ he claimed that God is the judge of the blood of their [of the Byzantines] ancestors, which cries to God every day among them [the Byzantines] because of the spread of the Latin innovation there [probably in Constantinople] and in many other places. ${ }^{374}$ These remarks invoke the Biblical story of Cain and Abel, in which God himself confronts Cain with the fact that he murdered his own brother, Abel, whose blood, according to God, cries

\footnotetext{
372 PAPADAKIS, Aristeides: Anathema. In KAZHDAN, Alexander - TALBOT, Alice-Mary (Edd.): The Oxford Dictionary of Byzantium. New York, Oxford, Oxford University Press, 1991, p. 89.

${ }^{373}$ I accept the datation of the letter proposed by Blanchet. See BLANCHET, Marie-Hélène: Georges-Gennadios Scholarios (vers 1400 - vers 1472). Un intellectuel orthodoxe face à la disparition de l'Empire Byzantin. Paris, Institute Français d'Études Byzantines, 2008, p. 441. Henceforth BLANCHET 2008.

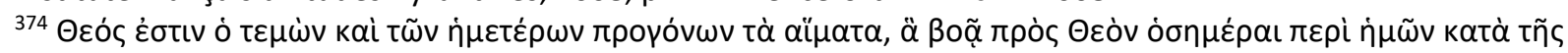

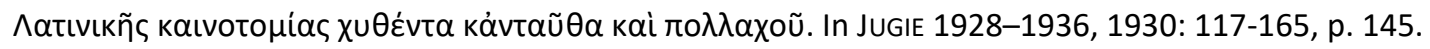


out to him in Heaven from the ground. After that, the murderer Cain receives the curse of God as a punishment for his terrible deed. ${ }^{375}$

It was an extremely charged statement to make in contemporary Byzantine society. According to this understanding, those who accept the Union of the Churches, are paralleled with Cain, while their forefathers appear as the equivalents of the unfortunate Abel, and the role of the killer weapon is given to the spread of Latin innovation. In this context, those disparaged by Scholarios are presented as even worse than the first murderer himself, as they spiritually split the blood of all their faithful Christian ancestors through their acceptance of Latin religious 'errors' or through their cowardice to act against them.

The punishment of eternal damnation is strongly suggested by Scholarios through his reference to God as the judge for the spread of the mentioned blood. Therefore, this entire argument by him can be understood as a device of inciting guilt and fear into his possible audience, branding the Unionists as quasi-murderers of their own Christian ancestors, while implicitly threatening them with the prospect of spending eternity in Hell.

Furthermore, Latin innovation is not only associated with religious 'error' but also receives a strong moral aspect through its association with innumerable spiritual murders that clearly brands its adherents too. The lines of Scholarios suppose a religious and a moral boundary, which are logically connected to each other, and anti-Unionists occupy their 'right' side, while the Latins and the Unionists occupy their 'wrong' side. Importantly, these two intertwined boundaries, both of which operate only with the categories of praiseworthily right and condemnably wrong, do not coincide with the boundary created by ethnicity. Byzantines who reject the Union are not only separated by them from the Latins, but also from those Byzantines who support it.

\section{VI.3. The Morals of Babylon}

A unique judgement on Latin morality is to be found in the Epistula encyclica contra Graeco-Latinos et decretum synodi Florentinae of Markos Eugenikos. The author claims that those who (the Unionists) captured them (the anti-Unionists) into a harsh captivity also want

\footnotetext{
${ }^{375}$ And the Lord said, "What have you done? Listen; your brother's blood is crying out to me from the ground! And now you are cursed from the ground, which has opened its mouth to receive your brother's blood from your hand. When you till the ground, it will no longer yield to you its strength; you will be a fugitive and a wanderer on the earth." NRSV Gen 4, 10-12.
} 
to reduce them to the Babylon of Latin habits and dogmas. ${ }^{376}$ For deciphering this reference, one should remember that Babylon is represented as an incredibly sinful city in the Bible and its inclusion in the New Testament Book of Revelation is traditionally interpreted by both the Orthodox and Catholic Churches as a symbol of the polytheist Rome of the $1^{\text {st }}$ century AD. ${ }^{377}$ Regarding the role of the city of Rome as the official centre of the Catholic, that is, 'Latin' Church, the moral associations of Babylon in Christianity and this traditional interpretation in the Book of Revelation, the reference could have suggested parallels between the idea of the sinful Babylon, the, according to the Christian tradition, appalling morals of the polytheist Rome and the ones of the Catholic Eternal City for a theologically erudite audience.

Furthermore, if Latin habits and dogmas are presented as ones comparable to Babylon, it defines them as theologically wrong ones and morally abysmal, which stands in a sharp contrast with Orthodox habits and dogmas, which are clearly understood as theologically 'correct' and morally right in the entire work of Eugenikos. Naturally, the evaluation of habits and beliefs effects the evaluation of their adherents too, associating the same theological and moral qualities with them, respectively. Catholic Latins and Unionists are again placed at the 'wrong' side of both a theological and a moral boundary, while anti-Unionist Byzantines repeatedly appear at the right side of them. Anti-Unionists also appear as the victims of two abuses, first, the 'captivity' of the Union and second, the attempt to make them follow the Latin habits and dogmas, while Unionists are defined as the perpetrators of both abuses, further enhancing their alleged moral qualities.

\section{VI.4. Failing Arguments and Their Failing Adherents}

Another peculiar charge can be found in one of the theological letters of GeorgiosGennadios Scholarios. In this source, he claims that there is no reason to fear that the Latin arguments will ever be 'stronger' than their (of the Orthodox) ones as they (the Orthodox) stand so highly over the Latins both in the respect of 'godliness' and of human honour. ${ }^{378}$ The

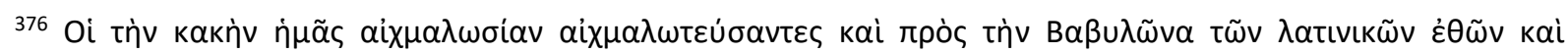

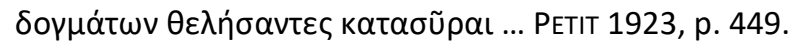

377 There is an alternative tradition understanding the Babylon of Revelation as a symbol of Jerusalem, but it is a younger one than the interpretation arguing the identification with Rome and more arguments support the latter view. For a brief yet detailed analysis of the two hypotheses, see BIGUzzI, G.: Is the Babylon of Revelation Rome or Jerusalem? Biblica 87 (2006) No. 3, pp. 371-386, esp. pp. 380-386.

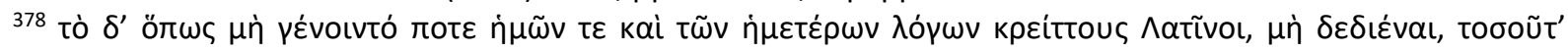

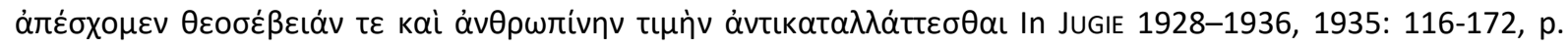
121.
} 
use of the attribute 'stronger' follows a traditional use of the term in Greek literature: it expresses that a concept is 'more valid' than another one.

The anti-Unionist Scholarios unsurprisingly portrays Orthodox teachings as more valid than the Catholic ones and, as a clear consequence of adherence to their respective teachings, Orthodox believers, including the Byzantine anti-Unionists, as representatives of a far higher moral niveau, than the Latins and the Byzantine Unionists, both in its strictly religious and in its more secular manifestations.

Regarding the connection between the validity of religious teachings and moral behaviour of their adherents, envisioned by Scholarios, it is also important to mention that this argument is connected to an important tenet of Orthodoxy, namely that only a perfect creed can lead to sanctification and salvation. ${ }^{379}$ Therefore, the argument of Scholarios, that apparently establishes a hierarchical relationship between the Orthodox and the Catholic creeds, based upon their effectivity in inciting moral behaviour, implicitly questions the ability of the Catholic creed to assist the salvation of its adherents, which represents a far higher level of condemnation.

\section{VI.5. Papal Primacy}

The problem of papal primacy started its long development in Late Antiquity. At the beginning of the $4^{\text {th }}$ century AD., the see of Rome was regarded as equal to the other four members of the Pentarchy of the most important Christian bishoprics, Constantinople, Alexandria, Antioch and Jerusalem. The tradition that the bishopric of Rome was founded by the apostles Peter and Paul, and the rivalry between Constantinople and Alexandria gave an opportunity for Rome to achieve the highest position in the Pentarchy. One of the key elements of papal primacy was plenitudo potestatis, the Pope's absolute power, which was originally limited to ecclesiastical matters, accepting secular affairs as the domain of the Emperor. However, in the $8^{\text {th }}$ century the popes started to claim that their plenitudo potestatis involved the political sphere too. The see of Constantinople traditionally rejected the concept of papal primacy, leading to a long conflict with Rome. In the $14^{\text {th }}$ and $15^{\text {th }}$ centuries, the

\footnotetext{
379 TURneR, C. J. G.: Another Anti-Latin Work Attributed to Gennadius Scholarius. BZ 58 (1965), pp. 337-347, p.
} 345. 
papacy demanded the recognition of its primacy: a condition of Church Union and Catholic military assistance against the Ottomans. ${ }^{380}$

The problem of papal primacy appears in an interesting way in one of the letters of Demetrios Chomatenos, which is more precisely an actio synodica, dealing with the problem of the Bulgarian bishops ordained by the Bulgarian patriarch after 1204, without any 'Roman' corroboration. As Theodoros I Komnenos Doukas reconquered considerable territories from the Bulgarians in Western Macedonia after 1215, including Ochrid, and achieved the Bulgarian acceptance of the authority of the archbishop of Ochrid appointed by him, that is, of Chomatenos. The question of the earlier, independent Bulgarian ordinances in his large archdiocese was a serious problem for the new archbishop, but an Epirote synod in 1219 accepted them, if they were performed by a Byzantine-appointed bishop. ${ }^{381}$

However, the Latins are involved in his description of the tumultuous years before the compromise. Discussing the status of the head of the contemporary, independent Bulgarian Church, Chomatenos invokes the circumstance that he was ordained as archbishop by the bishop of Vidin and two other bishops, who were appointed by the Byzantine Church before 1204, even if this man had received the title of patriarch by a cardinal of the Pope later. ${ }^{382}$

The cardinal of the pope promoted the head of the new Bulgarian Church to a primate, and not a patriarch. ${ }^{383}$ Nonetheless, it still makes it clear that Bulgaria accepted papal primacy. The reasons for so few words being paid to this episode are uncertain; it may be explained with its perception as a scandalous deed in the eyes of the Epirote ecclesiastical authorities, with a possible intent to avoid any unnecessary provocation of the Bulgarian clergy, or with its limited importance for the main subject of the text.

However, as the acceptance of papal primacy violated Byzantine church policies and the invocation of this event is to be found within a part of the source that enumerates the

\footnotetext{
${ }^{380}$ For a brief summary of the contemporary Catholic teachings on papal primacy, see PAPADAKIS, Aristeides: The Byzantines and the Rise of the Papacy: Points for Reflection, 1204-1453. In HINTERBERGER, Martin - SCHABEL, Chris (Edd.): Greeks, Latins and Intellectual History 1204-1500. Leuven - Paris - Walpole, MA, Peeters, 2011, pp. 1942, pp. 21-27.

${ }^{381}$ NICOL, Donald M.: Refugees, Mixed Populations and Local Patriotism in Epiros and Western Macedonia after the Fourth Crusade. In XVe Congrès international d'études byzantines. Athens, 1976, pp. 1-33, p. 22.

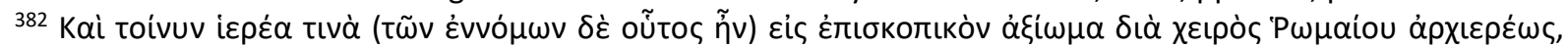

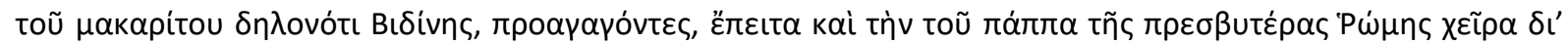

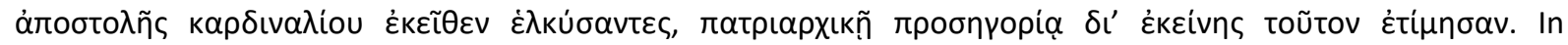

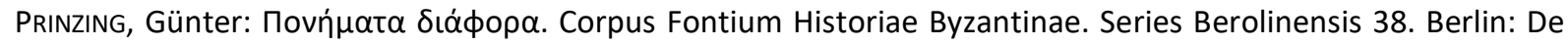
Gruyter, 2002, p. 424.

383 ANGOLD, Michael: Church and Society in Byzantium under the Comneni, 1081-1261. Cambridge, University Press, 1995, p. 534.
} 
'misdeeds' of the Bulgarian clergy and its decisions that are questionable if judged relying on Orthodox theology, its perception as a condemnable act is clear, just like the intent to promote it as such for the audience. Acknowledgment of the authority of the Holy See is defined as a morally unjustifiable behaviour and an erroneous theological tenet, which, as all Catholics adhered to this teaching, associated them all with these concepts. This criticism of the acceptance of papal primacy reinforces the theological and moral boundaries between Orthodox and Catholic believers, including most Latins and most Byzantines, respectively, and envisions a far higher standing for the Orthodox than for the Catholics in both cases, underlining Byzantine superiority to Latins.

\section{VI.6. A Church Union Built upon Far Too Material Grounds?}

In his Epistula encyclica contra Graeco-Latinos et decretum synodi Florentinae Markos Eugenikos presents a different and most peculiar accusation. He states commenting on the aims of the Unionists that they (the Unionists leaders) did not come together with the Latins to inquire the truth, as they claim, but wanting to smelt ore to extract gold from it. ${ }^{384}$

How should one interpret this strange accusation? Beside referring to smelting ore for gold, the verb $\chi \rho v \sigma o \chi o \varepsilon ́ \omega$ also had a proverbial meaning of 'failing in any speculation', tracing its roots to an alleged futile attempt in Ancient Athens, when certain Athenians tried to extract gold from silver-ore. ${ }^{385}$ This humorous connotation of the word should have been well-known for the educated segments of his targeted audience, and associated the Unionist leaders both with greed and ignorance. The image of the Athenian simple-mindedness of dubious historicity creates an especially powerful dichotomy with the image of seeking the truth, an activity that supposes intelligence and a level of prior knowledge, besides implying that the leading pro-Latins did not receive what they hoped for.

Furthermore, there is another dichotomy of moral nature in the source, as Markos Eugenikos alleges that the Unionist leaders merely claimed that they were seeking the theological truth, while actually they were struggling to acquire wealth by establishing a church union. This brands them as liars and people who sacrifice theological truth and the independence of the Orthodox Church for money.

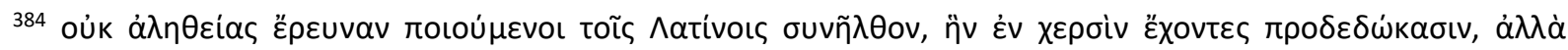

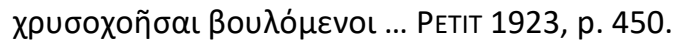

385 PI.R.450b, cf. Din.Fr.6.13, Harp. See LIDDEL, Henry George - SCOTT, Robert - JONES, Henry Stewart - McKENZIE, Roderick (Edd.): Greek-English Lexicon. Ninth Edition with a Revised Supplement. Oxford, University Press, 1996, p. 2011.
} 
As this money supposedly had to come from the Catholic Church, it suggests that the Westerners are ready to further their ecclesiastical agenda through such lowly methods, which brands them too as morally depraved persons. Moreover, all of this is to be measured to the implicitly present moral excellence of the prominent anti-Unionists, showing the supporters and the opponents of the Union as strikingly different with regard to morality. It suits Markos Eugenikos, who was not only a sworn enemy of the Union but regularly utilised strong ad hominem arguments against his opponents. ${ }^{386}$

\section{VI.7. Obscurant Rejection of the Latin 'Religion' and 'Sacrifices'}

A letter in the corpus of Ioannes Apokaukos, archbishop of Naupaktos written to an unknown priest in Patras, proclaims that nobody among the Fathers accepts either the religion or the sacrifice of the Latins. ${ }^{387}$ A peculiar problem posed by this remark is the definition of "Fathers" used by the author. The term "Fathers" could refer to the Church Fathers, the Greek Fathers and even the Latin Fathers. However, regarding that Apokaukos was a Byzantine metropolitan archbishop and wrote his letter after 1204, the possibility of him referring to the Latin Fathers is negligible.

Besides, although it would seem logical to understand the very prestigious group of the Church Fathers under the designation because of their sheer authority, Byzantines tended to use the term 'fathers' as a category that covered all the eminent Orthodox theologians they respected as important scholars of the Orthodox faith. ${ }^{388}$ For this reason, it is very probable that Apokaukos uses the term with this meaning.

Relying on this definition for the interpretation, the metropolitan archbishop establishes a rigid boundary between Roman Catholicism and Orthodoxy, as the latter is defined by its 'fathers', that is, authoritative theologians, whose religious views, according to Apokaukos, are in contrast to Catholic ones. The fields in which he identifies these differences are 'religion' ( $\theta \rho \eta \sigma \kappa \varepsilon i ́ \alpha)$ and 'sacrifice’ ( $\theta v \sigma i ́ \alpha)$, overly broad categories, which can be narrowed on the basis of probability.

For instance, $\theta \rho \eta \sigma \kappa \varepsilon i ́ \alpha$ can mean 'creed', which then would point to the Filioque as the prime subject of Orthodox objections against the Latin creed, while $\theta v \sigma i ́ \alpha$ with its core

\footnotetext{
${ }^{386}$ GILL 1959, pp. 318-319.

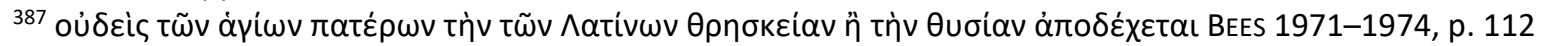

${ }^{388}$ A good example for this practice is the Panoplia dogmatike of Euthymios Zigabenos, in which he considers each Orthodox theologian invoked by him as a member of the group of the 'fathers'. See JUGIE, Martin: La vie et les oeuvres d'Euthyme Zigabène. In: Échos d'Orient, tome 15, N94 (1912) pp. 215-225, esp. 218-223.
} 
meaning 'sacrifice' invokes the vehement Orthodox opposition to the Catholic use of unleavened bread in the Eucharist, the infamous azymes-controversy. In this system, Catholicism is presented as an 'erroneous' religion in at least two of its core aspects, while Orthodoxy as 'the true' one.

The alleged characteristics and the strict dichotomy of these two Christian denominations are expended by Apokaukos even to their adherents, the Latins, that is, Westerners, and the Orthodox nations too, whose characteristics are suggested to be in harmony with that of their faith. Unfortunately, the text of the letter is damaged, and it abruptly ends with the sentence discussed above, depriving the historian of any details that could potentially precise the nature of the accusations.

\section{VI.8. Latins 'Talking All Kind of Things About God'}

Furthermore, another letter of Gregorios, written to the philosopher Gregoras, posed a rhetorical question. As he says, regarding the [discourse] against the Latins and against those who dare to talk all kinds of things about God, which he [Gregoras] has just read, what should be said? ${ }^{389}$ The obscure reference to the 'discourse' means the speech that Gregoras read in the presence of the patriarch of Constantinople, Ioannes XIV Kalekas (1334-1347) in 1334. 390 The main focus of the text was on the alleged theological innovations of the Catholic Church in relation to the fact that two papal legates resided in the Byzantine capital at the time and the patriarch asked theological advice from Gregoras in the upcoming debate with the Catholic emissaries with them. The speech had nothing to do with the teachings of Palamas (the Palamite controversy was yet to start), but one of its core arguments was the incomprehensibility of God, which was easily adaptable against Palamism. ${ }^{391}$

The claim that certain people 'talk all kinds of things about God' is in itself a loaded one, as it invokes the image of those whom it refers to speaking the widest range of nonsensical things about God, a very discrediting claim in the eyes of contemporary Orthodoxy. However, its combination with the term 'dare' also conjures the impression of this behaviour being outrageous and condemnable.

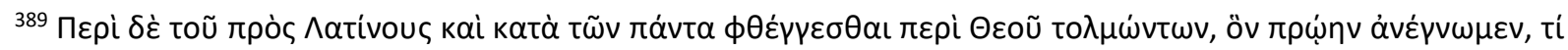

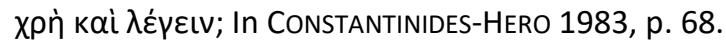

390 CONSTANTINIDES-HERO 1983, p. 342.

${ }^{391}$ BEYER, Hans-Veit: Nikephoros Gregoras als Theologe und sein Erstes Auftreten gegen die Hesychasten. JÖB 21 (1971), pp. 171-188, p. 175.
} 
In this context, 'the Latins' appear as a group parallel to those who 'talk all kinds of things about God', which suggests that such behaviour is not at all alien to the Latins, with a potential to enhance hostility against them in the Orthodox audience. In the context of the charges voiced by Akindynos, Westerners are primarily defined by their religious views and the main boundary between them and the Byzantines is portrayed as being religious in nature. This religious boundary separates the Byzantine, Orthodox, logical and 'right' views from the Latin, Catholic, illogical and 'wrong' views.

It is worth underlining again that the original speech dealt exclusively with the views of the Latins. Those who 'talk all kind of things about God' are a rather obvious designation of the contemporary theological opponents of Gregoras, that is, the adherents of Palamite teachings. Paralleling them with the Catholics was a useful device to question their Orthodoxy, due to the already traditional religious prejudices against Westerners within Byzantine society.

\section{VI.9. Religious ‘Corruption' Spread by Latin Monks}

Konstantinos Akropolites (1250-1324) $)^{392}$ wrote a letter of recommendation for the monk Auxentios to the abbot of the monastery of Chortaites ${ }^{393}$ in Thessalonike. ${ }^{394}$ According to Akropolites, he [Auxentios] has come to the Italians on the [coast] opposite to them [Byzantines], who forsooth have chosen the monastic life and are called 'perdikatouroi' in the unyoked language of the Italians - as the monastic body is divided into many parts by them [the Catholics], as he [the abbot] knows - and he [Auxentios] promised, binding his knees, that he wanted to be united with them [with the Italian monks] in regard of others [logically in

\footnotetext{
392 On the life of Akropolites see NICOL, Donald M: Constantine Akropolites: A Prosopographical Note. DOP 19 (1965), pp. 249-256.

393 The monastery of Chortaites was located in the city of Thessalonike, and, besides the letter of Konstantinos Akropolites, there is another 13th-century source which mentions it, which is a contract between the monasteries of Chortaites and of Iviron on Mount Athos on the exchange of certain properties. The final Turkish attack against Thessalonike during the siege of the city in 1430 concentrated itself to the area in which the Chortaites monastery stood and nowadays the facility is not extant anymore. JANIN, Raymond: Les églises et les monastères des grands centres byzantins. Paris, Institut Français des Études Byzantines, 1975, pp. 414-415.

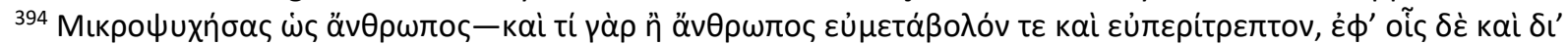

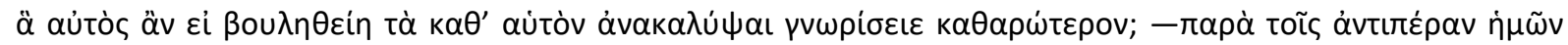

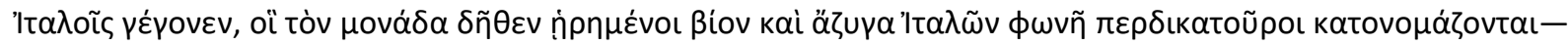

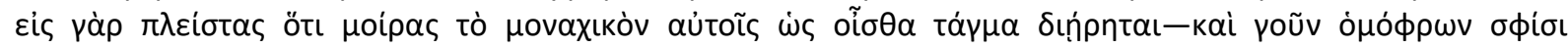

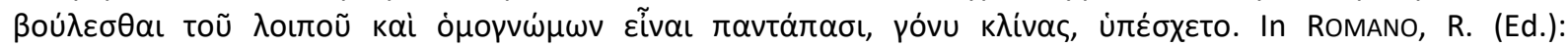
Costantino Acropolita, Epistole [Speculum. Contributi di Filologia Classica Naples: M. D'Auria, 1991]: 109-268. p. 186. $93^{\text {rd }}$ letter
} 
those aspects of religion in which he differed of them until then] and [wanted] to be likeminded [to them] in everything.

Italians in this reference are primarily defined by their geographical positions: on the coast opposite to the Byzantines, stating a geographical boundary between the two ethnic groups. It situates the presentation using the two sides of the Straits of Otranto, locating the Westerners on question in the Kingdom of Sicily/Naples ruled by the Capetian House of Anjou in the adult life of Akropolites. The author then narrows his focus to a subgroup, identifying the agents of his story as monks.

However, the step Akropolites makes after that is of special importance, as he claims that the people involved in his story are called 'perdikatouroi', an easily decipherable version of the Italian word 'predicatori', that is, preachers, and states that it is their name in the 'unyoked language of the Italians'. He explicitly identifies the use of a peculiar language with the Italians, which is one of the traditional characteristics of an ethnic group.

Thereby, he also defines Italians as an ethnic category different from the Byzantines. Nonetheless, Akropolites comments on this language and calls it 'unyoked', a term with derogatory connotations, suggesting a language that is not 'refined'. The term also conjures up the image of low cultural niveau among the Italians, tacitly to be opposed by the 'civilised' language and culture of the Byzantines.

Following that, a final difference is established between the Italians and the Byzantines by Akropolites. This is the existence of divisions within the monastic body among the Italians, with other words, the existence of multiple monastic orders in the Catholic Church. This is implicitly compared to the absence of different monastic orders in Orthodoxy, its obviousness underlined by the addition that the addressee is surely aware of this circumstance.

Regarding Auxentios himself, he is claimed to have gone to the Italian monks, and kneeling, which is a traditional gesture of submission, declared his intent to join them and share all their dogmas. It is a theatrical description of an Orthodox monk joining Roman Catholic monasticism, even if it is not determined, whether Auxentios merely expressed that he wanted to join Catholic monasticism or happened to specify a certain religious order. In any case, it was a deplorable behaviour in the understanding of the contemporary Orthodox Church. 


\section{VI.10. The Necessity of Purging the Church of Latinizers}

Ioannes Eugenikos, writing to Demetrios Palaiologos, the despot of the eastern parts of the Morea, in $1453^{, 395}$ intended to provoke action by the governor against the unionist policies of the Byzantine government and convince him to oust the four pro-Latin bishops of Amyklai, Elis, Karyoupolis and Monemvasia, thus purifying the Church. ${ }^{396}$

Eugenikos invoked a scenario in which they [the authorities] dare to accept him [the proLatin bishop of Elis] as bishop, who is disobedient and [only] plays a priest, and who boldly affirmed with deeds and words that [he] is with the Latins and dies with them. ${ }^{397}$ If the conjecture of Zakythinos is correct and Ioannes Eugenikos was indeed the administrator of the Metropolitan See of Lakedaimon when he wrote his letter, then the bishop of Elis, unnamed like the other three clergymen accused by Eugenikos, was his only target beyond his jurisdiction, making it the more understandable to seek assistance by secular authorities.

It is also important to mention that the addressee, Demetrios Palaiologos had been a longtime anti-Unionist, so an understanding attitude towards the demands of Eugenikos was predictable. However, the bishopric of Elis lay in the domains of the despot of the western part of the Morea, Thomas Palaiologos, who was a Unionist, meaning that his brother, the despot Demetrios, had no power to oust the bishop of Elis. What is more, his support was of rather dubious value in convincing Thomas Palaiologos to turn against the high priest of Elis.

Ioannes Eugenikos does not name the Latins explicitly in this sentence. However, certain characteristics of Westerners are still identifiable in it. As the letter is predominantly concerned with certain perceived adverse effects of the Union with the Catholic Church, and the bishop is effectively called a false priest, who is claimed to have demonstrated that he tied his own life and death to the Latins, being Latin is very much defined by religious adherence.

However, the bishop of Elis, suggested to be a person who rejected Orthodoxy for Catholicism, is still not designated by Eugenikos as a Latin, but as someone who is a stalwart ally of the Latins. It points to an underlying and important ethnic dimension of being Latin. Accepting the Latin faith does not make somebody a Latin in this context.

\footnotetext{
395 The exact date of the letter is uncertain, Tsirpanlis dated it to 1453. TSIRPANLIS, Constantine N.: John Eugenicus and the Council of Florence. Byzantion 48 (1978), pp. 264-274, p. 270.

${ }^{396}$ Zakythinos suggested on the basis of this letter, that loannes Eugenikos was the administrator of the Metropolitan See of Lakedaimon at the time of writing this letter. ZAKYTHINOS, D. A.: Le despotat grec de Morée II (Athens, 1953), p. 286.

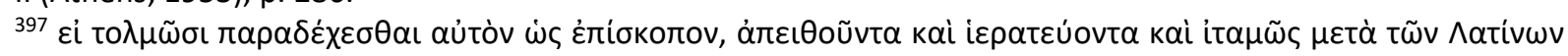

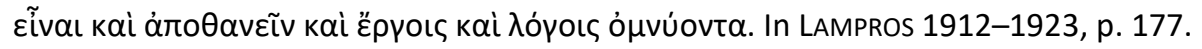


As Eugenikos depicts leaving Orthodoxy and joining Catholicism as a condemnable act, it is also clear that his model supposes the superiority of the Orthodox faith over the Catholic one at least. In light of the contexts of the letter, the religious profile of Ioannes Eugenikos, and contemporary anti-Latin polemics it can be conjectured that this 'superiority' relies on an understanding of Orthodoxy being the 'true' faith and Catholicism being an 'erroneous 'one', with perceived moral consequences among their adherents.

\section{VI.11. No Surrender to the Anathematised Latins}

In a letter addressed to the metropolitan archbishop of Larisa in Thessaly, ${ }^{398}$ Lazaros the Monk $^{399}$ attempted to convince the addressee about his own views. The letter was written during the Unionist course of Emperor Michael VIII Palaiologos, which fact probably contributes to the harsh tone of the source. Lazaros claims that he is very far from cowering before the Italians, according to the union and approval of their priests (the Byzantine high clergy), so as to surrender God to the Latins, and to swallow this bait of compensating them (the Byzantines) for their (of the Latins) impious deeds, for which (impious deeds) they (the Latins) were anathematised by the Orthodox Church and were absolutely removed (from the Church), like rotten and destroyed parts of the body. ${ }^{400}$

Lazaros here concentrates on alleged Latin wickedness. The Catholics appear as a group which was cast out of the Church and was anathematised for its impious deeds. The parallel of these actions, that is, the removal or gangrenous tissue from a human body, invokes a particularly intense image of an amputation, a traumatic experience characterised by extreme suffering, cankered flesh and a maimed body that remains after the operation. The Church, identified with the Orthodox believers, appears as the still living, healthy part of the theoretical body, while adherents of Roman Catholicism are equalled with rotting gangrenous tissue, which must be cut out from the body for the survival of the still living part of the body - an extremely condemning verdict on Catholicism.

\footnotetext{
398 Probably identical with archbishop Thomas of Larisa, who was a loyal and influential supporter of Michael VIII Palaiologos (1258-1282) and supported the deposition of Patriarch Arsenios Autoreianos in the synod of 1265. PLP 7786.

399 Lazaros may be identical with a monk of the same name who died in the Akapniou Monastery 28th March 1277. PLP 14329.

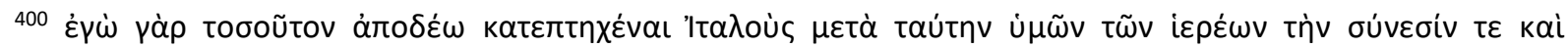

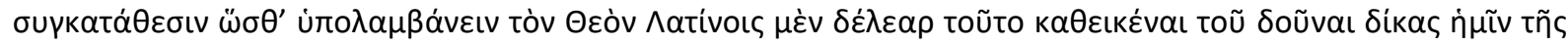

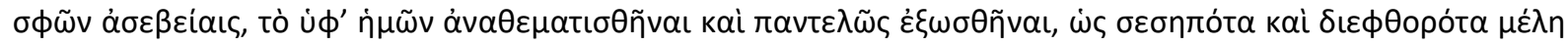

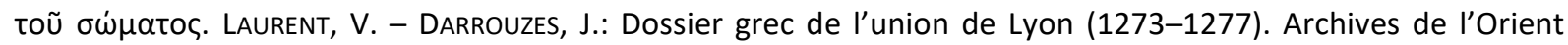
chrétien 16. Paris, Institut Français d'Études Byzantines, 1976, pp. 538-553, p. 545.
} 
As leaving gangrenous tissue in the body inevitably leads to further necrosis and finally death, its amputation is a question of medical necessity, and the parallel transfers this impression of necessity to the casting out of Catholics from the Church. But it also displays Orthodox believers as the suffering victims of the operation, living with its consequences; in other words, the maimed body of the once whole Church, the memories of the once healthy theological body and the traumatic experience that lead to its mutilation. Meanwhile, Catholics are framed as both the dead flesh, impossible to save, and the cause of the suffering of the surviving, still healthy parts of the body, as they became what they are by their own free will, through their persistent impiety, bearing a responsibility for all the consequences of their straying, including the suffering of the Orthodox believers.

However, claiming victimhood does not end at this point. On the contrary, the union of the Churches, besides being illogical and dangerous, as any attempt to reattach its rotten flesh to a mutilated body, is also portrayed as a bait, suggesting malevolent machinations by the Latins, in hope of inflicting their appalling, corrupted state upon the spiritually still healthy Orthodox community, a gesture of extreme wickedness.

The grave nature of the situation is augmented by the claim that the high clergy of Orthodoxy became the engine of such an unholy communion, which, although Lazaros does not state it explicitly, is tantamount to betraying the faith and the community. Lazaros, who refuses to cower before the Latin, presents himself as a supposedly larger counterpole. This claim underlines his Orthodox faith and bravery, while implicitly also brands the high clergy accepting the Union of Lyons as cowardly or, even worse, adherent of erroneous beliefs.

The unnamed metropolitan archbishop is presented with the option of choice in this situation, where the only options are adherence to the Union, branded as cowardly and faithless, and resistance to it, portrayed as brave and Orthodox. The model of Lazaros is rigidly dichotomic and extremely tendentious, being a rather obvious attempt of manipulating the addressee through his attachment to his own Byzantine identity and fear of damnation instead of sophisticated theological arguments.

\section{VI.12. The Latins Speaking 'Righter' than an Orthodox Bishop}

In a letter, sent to an unknown bishop, without any address, ${ }^{401}$ Demetrios Kydones mentioned the accusations made by that bishop, that he [Kydones] corrupted the youth and

${ }^{401}$ Franz Tinnefeld dated the letter between 1371 and 1373. TINNEFELD 2010, p. 42. 
believed that the Latins speak righter and truer things than him [the bishop]. And he [the bishop] blithered a lot of other things and the slanders [of the bishop] against him [Kydones] did not have any limit. ${ }^{402}$

As Kydones comments on the case in the very same letter, he is convinced that the bishop had drunk too much wine before he started to disparage him, making the accusations far less threatening than they could have been if the bishop was sober when he voiced them. It is an open question whether Kydones was correct regarding the mental state of the fulminating bishop, but it is clear that such charges were harsh enough to demand an answer. The letter is presented as the answer given by Kydones and its claim about the drunken speech of the high priest can be understood in more than one way, from an actual representation of what had happened to an attempt to discredit the accusations among the possible audience (both contemporary and posterior) as alcohol-induced blether.

According to Kydones, the bishop accused him with corrupting the youth and preferring the Latins' claims to those of the bishop because of his perception of the Latin claims being righter and closer to truth, besides a seemingly endless collection of other slanders. As he does not specify the nature of these other accusations, research cannot state much more about them than that Kydones possibly wanted to suggest with the lack of details that these charges did not deserve any more description, being so ludicrous ones.

The two other statements prove to be less evasive for the present analysis. Corruption of the youth was a loaded accusation, as, according to Platon in his Apologia, it was one of the main charges against Sokrates in his case that ultimately led to his death sentence. The process of Socrates was generally represented as an infamous show trial in the culture of PostClassical Greco-Roman Antiquity, which interpretation was adopted by Byzantium. Therefore, a claim that the bishop accused him with that had a serious potential to invoke this interpretation in the minds of the educated audience, and to frame Kydones as an innocently persecuted intellectual and the bishop and his potential supporters as unjust persecutors. As Tinnefeld stated, the fact that Kydones makes a reference to the nearing Easter, and with that, to the Passion of Christ, could strengthen the impression of an innocent man suffering persecution by wicked people. ${ }^{403}$

If the anonym bishop complained about the effect of Kydones on Constantinopolitan youth indeed, then he most probably referred to the notable intellectual circle formed around

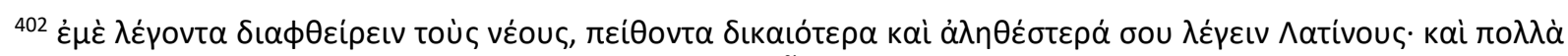

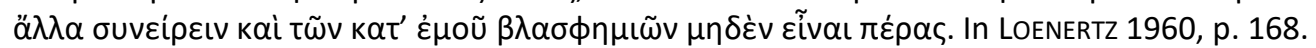

${ }^{403}$ TINNEFELD 2010, p. 43.
} 
the mesazon, who had already been a Catholic at the probable time of the charges, and to the fact that members of this circle were generally tolerant towards Catholicism and the Latins, while many of them had a problematic relationship with contemporary Orthodoxy. 404

This provides the logical connection between the first and the second accusations, the latter being the alleged claims of Kydones deeming Latin teachings righter and closer to truth than the teachings of the bishop, that is, Palamite Orthodoxy. This claim had some factual basis, as Kydones has voiced his sympathies towards Roman Catholicism and criticised the contemporary state of Orthodoxy, in texts intended to have a certain publicity, already before the 1370s, notably in his Apologia I, which he wrote around 1363, and in his Oratio pro subsidio Latinorum, dated to 1366 , both in a period when even his political influence was relatively strong. ${ }^{405}$ So, if such a charge was brought up by the bishop against Kydones, it was far from being a fictitious one, although the degree of awareness of the high priest is uncertain.

Scrutinizing the image of the Latins in the source, the key factors are the claims attributed to the bishop, namely that he accused Demetrios Kydones with believing that the Latins speak righter and truer things than the bishop himself. Regarding the context, there is no reason to doubt that the Latin statements to which the bishop referred, according to the letter, addressed religious subjects. Therefore, the categories of rightness and truthfulness should be understood with a religious meaning.

These categories, precisely not defined in the source, appear as contested by two sides, the bishop, who represents the entire community of Orthodox theologians, and the Latins, who are to be identified with all of the Catholic theologians. It defines the boundary between the Latins and the Byzantines, stressed by the presentation attributed to the bishop, as one of profoundly religious nature.

Religious rightness and truthfulness are absolute categories of great importance for believers, especially for those who make other values depend on the 'correct' views on them, usually moral or intellectual qualities. Besides, Byzantine imperial ideology supposed a strong correlation between adherence to Orthodoxy and loyalty to the state. So, if the bishop thought that Kydones regarded the views of Catholic theology righter and truer than the views of

\footnotetext{
${ }^{404}$ For the intellectual circle of Kydones and its attitudes towards Roman Catholicism and Palamite Orthodoxy, see RUSSELL, Norman: Palamism and the Circle of Demetrius Cydones. In DendRINOS, Charalambos - HARRIS, Jonathan - HARVALIA-CROOK, Eirene - HERRIN, Judith (Eds.): Porphyrogenita. Essays on the History and Literature of Byzantium and the Latin East in Honour of Julian Chrysostomides. Aldershot, Ashgate, 2003, pp. 153-174, especially pp. 173-174.

405 On the Apologia I, the Oratio pro subsidio Latinorum and the views voiced by Kydones on Orthodoxy and Catholicism, see RYDER 2012B, pp. 171-173.
} 
Orthodox theology, it was unsurprising if it invoked very disturbing images in his mind. More precisely, with regard to Catholic teaching representing a 'higher quality', Kydones, the imperial mesazon, considered Orthodoxy as suffering from certain intellectual and moral problems, and being disloyal to the Byzantine state. The idea of a bishop aware of the religious views of Kydones and fulminating against him for these beliefs was not an unrealistic one.

\section{VI.13. Conclusion}

The subjects voiced by the authors of the letters analysed in this chapter encompass a wide range of topics. It involves undefined accusations of heresy, the similarly vague category of innovation, references to the question of the papal primacy, just like such peculiar arguments as weak Catholic theological arguments being connected to Latin moral shortcomings, branding of the Catholic habits as 'Babylon', and insinuation of the Unionist camp being motivated not by a search for truth but by a search for Latin gold.

However, the strong negative connotations of these subjects do not explain that their mentions are predmoninantly devices of anti-Latin arguments. The reason behind this phenomenon may be that certain anti-Latin epistolographers of the Palaiologan Era displayed a curious level of creativity as they voiced their rejection of Westerners. It is also worthy of consideration that these occasional 'creative' charges may have remained unnoticed by the pro-Latin authors, or they had thought it futile to react to them, concentrating on regularly voiced charges against the Westerners. 


\section{Azymes}

Another common subject that is presented in the letters is the problem of the azymes. The word azymes (Plural azyma) referred to the unleavened bread used by the Latin and the Armenian Churches in the Eucharist, justified with the tradition that Jesus used unleavened bread at the Last Supper to institute the Eucharist. However, the Orthodox Church used leavened bread, called enzymes (Plural enzyma) and both sides were highly critical towards the other practice. ${ }^{406}$

\section{VII.1. A 'Politically Adept' Author}

In one of his letters, Chomatenos deals with a traditional difference between the Catholic and the Orthodox churches, as he speaks about the Latin practice of using azymes in the Eucharist to Konstantinos Kabasilas. The author begins with the statement that canon 70 of the Apostles, ${ }^{407}$ canons $37^{408}$ and $38^{409}$ of the Council of Laodikeia (363-364) and canon 60 of the Council of Carthage $(419)^{410}$ discuss heathen feasts and the Jewish practice of the

\footnotetext{
406 MeYendoRfF, John: Azymes. In KAzHDAN, Alexander - TALBOT, Alice-Mary (Edd.): The Oxford Dictionary of Byzantium. Oxford University Press, 1991. p. 241.

407 If any bishop, presbyter, or deacon, or any one of the list of clergy, keeps fast or festival with the Jews, or receives from them any of the gifts of their feasts, as unleavened bread, any such things, let him be deposed. If he be a layman, let him be excommunicated. PERCIVAL, Henry (TransI.): Canons of the Apostles. In SCHAFF, Philip - WACE, Henry (Eds.): From Nicene and Post-Nicene Fathers, Second Series, Vol. 14. (Buffalo, NY: Christian Literature Publishing Co., 1900.) Revised and edited for New Advent by KNIGHT, Kevin. <http://www.newadvent.org/fathers/3820.htm>.

${ }^{408}$ It is not lawful to receive portions sent from the feasts of Jews or heretics, nor to feast together with them. Percival, Henry (Transl.): Canons of the Council of Laodicea. In SCHAFF, Philip - WACE, Henry (Eds.): From Nicene and Post-Nicene Fathers, Second Series, Vol. 14. (Buffalo, NY: Christian Literature Publishing Co., 1900.) Revised and edited for New Advent by KNIGHT, Kevin. <http://www.newadvent.org/fathers/3806.htm>.

${ }^{409}$ It is not lawful to receive unleavened bread from the Jews, nor to be partakers of their impiety. PERCIVAL, Henry (Transl.): Canons of the Council of Laodicea. In SCHAFF, Philip - WACE, Henry (Eds.): From Nicene and PostNicene Fathers, Second Series, Vol. 14. (Buffalo, NY: Christian Literature Publishing Co., 1900.) Revised and edited for New Advent by KNIGHT, Kevin. <http://www.newadvent.org/fathers/3806.htm>.

${ }^{410}$ This also must be sought, that (since contrary to the divine precepts feasts are held in many places, which have been induced by the heathen error, so that now Christians are forced to celebrate these by heathens, from which state of things it happens that in the times of the Christian Emperors a new persecution seems to have secretly arisen:) they order such things to be forbidden and prohibit them from cities and possessions under pain of punishment; especially should this be done since they do not fear to commit such iniquities in some cities even upon the natal days of the most blessed martyrs, and in the very sacred places themselves. For upon these days, shame to say, they perform the most wicked leapings throughout the fields and open places, so that matronal honour and the modesty of innumerable women who have come out of devotion for the most holy day are assaulted by lascivious injuries, so that all approach to holy religion itself is almost fled from. In Percival, Henry (Transl.): Canons of the Council of Carthage. In SCHAFF, Philip - WACE, Henry (Eds.): From Nicene and Post-Nicene Fathers, Second Series, Vol. 14. (Buffalo, NY: Christian Literature Publishing Co., 1900.) Revised and edited for New Advent by KNIGHT, Kevin. <http://www.newadvent.org/fathers/3816.htm>.
} 
azyma forbidding Christians to receive them. Not any ancient canon remembers the Latin unleavened breads, so this practice, as Chomatenos argues, must have come into the Latin Church later. ${ }^{411}$ However, he states that he will not regard the azyma of the Latins as profane. ${ }^{412}$

However, he also states that if somebody claims that the azyma of the Latins are not profane and they [the Orthodox] will not err if they adapt this practice, it will be heard, that because of the things told above regarding the habits connected to the azyma and other ones [habits] of the Western Churches and regarding their [of the Orthodoxes] enzyma below, it will be impossible for both of them to transgress the ancestral habits. ${ }^{413}$

The first argument furthered by Chomatenos is that the azymes is a 'Judaising' practice, derived from Mosaic Law written in the Old Testament. It was one of the common Orthodox arguments against the use of unleavened bread in the Eucharist, branding it as invalid, and very often accompanied by harsh Antisemitic language and stereotypes. ${ }^{414}$ It is worth remarking that Chomatenos applies precise references to canons of Late Antique Councils that argued against the azyma, providing an argument which is accurate yet relies heavily on authority.

The references to authoritative Ancient sources also provide him a basis to argue that the use of azymes has to be a later development in the Western Church, as these Ancient sources do not mention it at all. It implicitly suggests that the Orthodox practice is the Ancient Christian and therefore the 'more authentic' one, establishing a hierarchy between Catholic and Orthodox liturgy, favouring the latter, which also creates a hierarchy between Latins and Byzantines, placing latters above the formers as adherents of a 'better' liturgical practice. These rather clear implications had to be reassuring in the eyes of a theologically literate Byzantine audience.

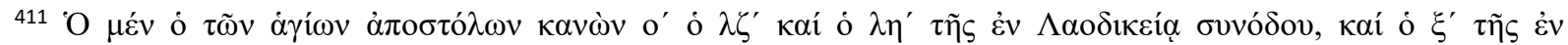

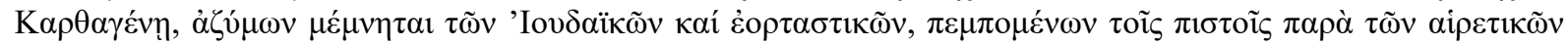

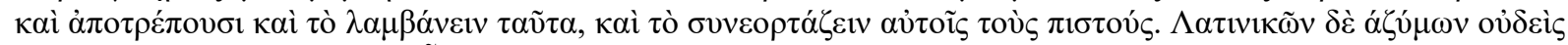

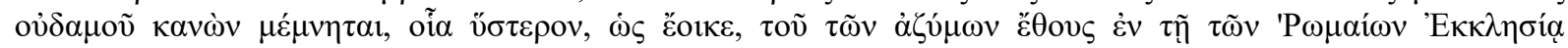
$\dot{\varepsilon} \pi \varepsilon 1 \sigma \kappa \omega \mu \alpha ́ \sigma \alpha \nu \tau o \varsigma$ PITRA, J. (Ed.): Analecta sacra e classica spicilegio Solesmensi parata VI (VII) (Juris ecclesiastici graecorum). Paris, 1891, pp. 625-630. Henceforth PITRA 1891.

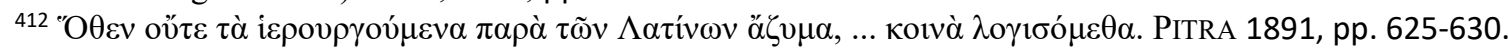

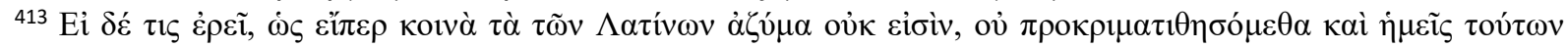

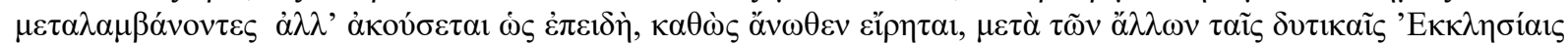

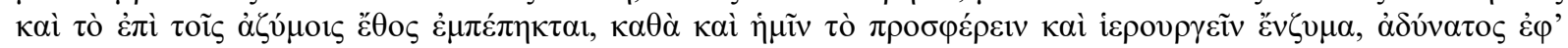

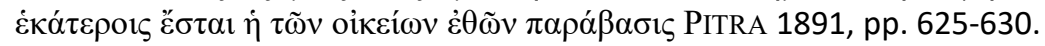

414 AvVaKumOV, Yuri Georgi: Die Entstehung des Unionsgedankens. Die lateinische Theologie des Hochmittelalters in der Auseinandersetzung mit dem Ritus der Ostkirche. Veröffentlichungen des GrabmannInstitutes zur Erforschung der mittelalterlichen Theologie und Philosophie 47. De Gruyter, 2002, pp. 103-107. Henceforth AVVAKUMOV 2002.
} 
More surprising is, however, his relatively tolerant approach towards the Latin practice. Unlike most Orthodox theologians after the Schism of 1054, he does not condemn the use of azymes in the Eucharist as profane, and even explicitly states that he does not consider it as such. Chomatenos continues his train of thought with the suggestion that eliminating this liturgical difference is extremely problematic mainly because it would be impossible for both parties without ceasing to adhere to their ancestral habits.

So, after he vindicated the status of the 'more authentic' practice for the Orthodox enzyma, yet argued for the validity of the Latin azyma, the author claims that changing the Eucharist of any side would mean a breakaway with their respective ancestral habits. Once again, Chomatenos applies a definitely authoritative approach, appealing to the, for the Medieval Christian mind, evident respect for previous faithful generations, to present the difference as considerable, yet insufficient to justify any hostility between Orthodox and Catholic believers and near impossible for both sides to adopt the other practice, thus suggesting the necessity of accepting the liturgical differences. This opinion was a surprisingly tolerant one considering other surviving Medieval Orthodox sources for the azymes-debate. ${ }^{415}$

Nothwithstanding this, the epistolary corpus of Chomatenos proves remarkably inconsistent regarding the opinions he expresses about the azymes. Another one of his letters, for instance, deals with the Eucharists and Sabbaths performed in Venice and Rome. Chomatenos frankly states that the sabbaths celebrated by the high priests of the Franks, with the Pope on the top of their hierarchy, and the azyma used for them are following the Mosaic law. ${ }^{416}$ In this case, the archbishop applies the 'Judaising' argument against the azymes, which claims its liturgical invalidity, without any sign of acceptance towards the Frankish, that is, Latin practice.

The use of the term 'sabbaths' for the Catholic Eucharists definitely serves to further this argument, and to enhance the impression of Roman Catholicism being strongly influenced by Judaism in the supposed audience. The Catholic habit of fasting on Saturdays

\footnotetext{
415 AVVAKUMOV 2002, pp. 114-116.

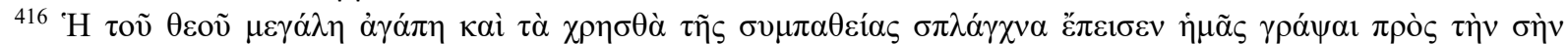

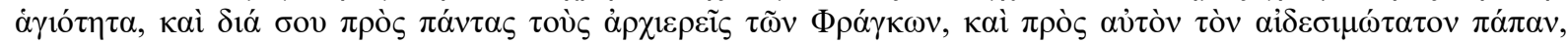

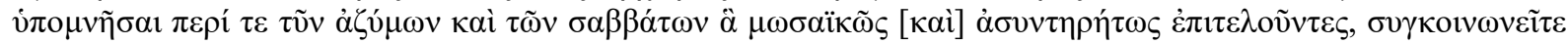

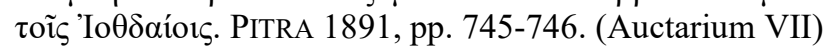


was often interpreted by Orthodox debaters as a celebration of the sabbath and Chomatenos seems to rely upon this strain of Orthodox anti-Latin polemics. ${ }^{417}$

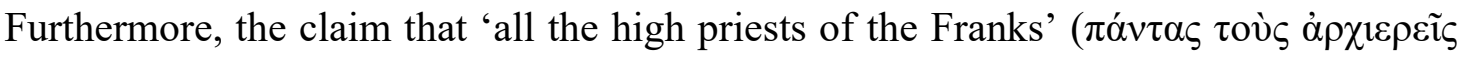

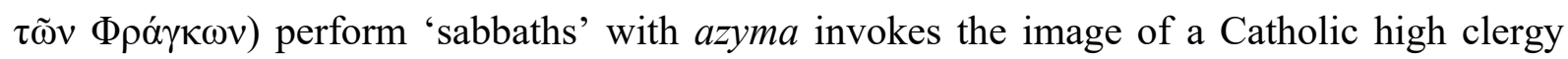
entirely committed to liturgical practices perceived as wrong by the Orthodox clergy. This generalisation also creates a model in which Catholicism is depicted as following a 'wrong' liturgical practice, while the implicitly present Orthodoxy follows the 'right' practice, granting a higher status for the latter denomination in this respect, which status-difference logically exists between their Latin and Byzantine adherents too. This rejective approach is far closer to the common view among the contemporary Orthodox lower clergy, namely the condemnation of the use of azymes as a heresy, ${ }^{418}$ than to the previous argumentation of Chomatenos addressed to Kabasilas.

Yet, these statements are still to be considered 'moderate' ones compared to a conspiracy theory proposed by Chomatenos in a letter that speaks about the beginning of the use of azymes by the Catholic Church. Chomatenos states that the Franks and the Lombards still consume the unleavened bread, without feeling any kind of shame about it. ${ }^{419} \mathrm{He}$ continues with the claim that certain Jewish converts to Christianity were still fanatic adherents of the Mosaic law and told to those baptised by them among the gentiles that if they do not practise male circumcision and keep the Mosaic law, then they could not be saved. The author states that this is the reason why the Franks still use the azymes when they celebrate the Sabbath. ${ }^{420}$

Through mentioning the Franks and the Lombards, Chomatenos refers to the French and the Italians, the two Western ethnic groups that contemporary Byzantines had the most contacts with, partly because of their strong presence in the Latin Empire, while the remark about their lack of shame of the use of azymes implicitly supposes the use of unleavened bread in the Eucharist being a shameful practice.

\footnotetext{
${ }^{417}$ AVVAKumov 2002, p. 105.

418 SCHABEL, Chris: The Quarrel over Unleavened Bread in Western Theology 1234-1439. In HINTERBERGER, Martin - SCHABEL, Chris (Edd.): Greeks, Latins and Intellectual History 1204-1500. Leuven - Paris - Walpole, MA, Peeters, 2011, pp. 85-127, p. 91.

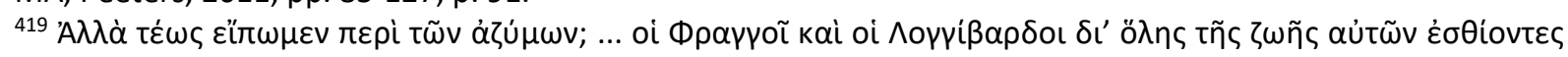

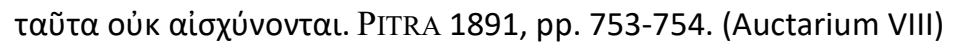

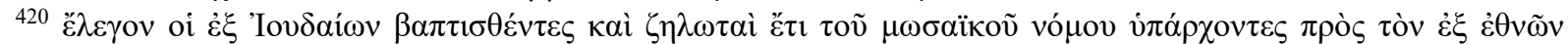

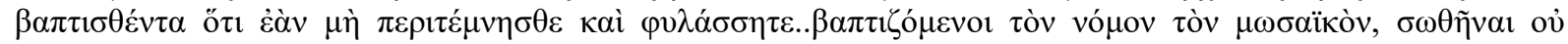

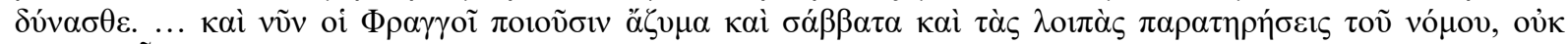

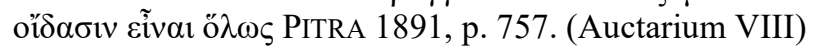


The astonishing part of the source comes with the fictitious story of certain Jewish converts to Christianity still adhering rigidly to the Mosaic Law and threatening converts made by them with the loss of salvation if they do not keep the Mosaic Law, including the practice of male circumcision. As it has been described above, supposing of a connection between the Jewish, Catholic and Armenian use of azymes was common in Medieval Orthodox theology. Condemnation of Jewish male circumcision also had a long tradition in Greco-Roman culture, dating back to the era of Hellenistic Culture. ${ }^{421}$

Such claims portray a very negative image of Catholicism, as it is charged with using azymes and even the possibility of practising male circumcision is left open by the author, both of which practices were viewed as 'Jewish' and 'wrong' by contemporary Orthodoxy. If Orthodoxy is to be understood as devoid of such 'errors', then the superiority of Orthodoxy compared to Catholicism has to be evident in this context. Moreover, it has the implication that the Byzantines and the Latins are separated by their different religions, and the former enjoy a much higher standing in this respect.

What is peculiar, even more than the conspiracy theory about a misinterpretation of Christianity by a group of Jewish converts leading to the use of azymes by the Catholic Church promoted by the metropolitan, is the presentation of a connection between male circumcision and Catholicism that had never practised it at all. It is hardly tenable to think that Chomatenos, a trained Orthodox canon jurist and theologian, would have not known this basic condition.

A rather probable explanation is that Chomatenos was perfectly aware of the fact that the Latins avoid circumcision, but he also knew that many among his supposed audience had only very limited knowledge about Catholic practices, so he may have intended to kindle their anti-Latin sentiments. Therefore, he deliberately left the opportunity to understand his words as the Latins practising male circumcision, a practice burdened by strong stereotypes among contemporary Orthodox believers.

The validity of this idea could have been ensured in the minds of his audience by the authority of the archbishop, and the libel would have strengthened their ant-Latin sentiments. It is also a conjecture, but the letter analysed below supports such a suggestion, as it offers another fictitious story on the origin of the azymes, making it the more probable that Chomatenos was not above distorting church history.

\footnotetext{
${ }^{421}$ EGO, Beate: Circumcisio. In CANCIK, Hubert-SCHNEIDER, Helmuth (Edd.): Der Neue Pauly. Enzyklopädie der Antike. Band 2. Metzler, Stuttgart-Weimar, 1997, p. 1209.
} 
In the source in question, Chomatenos claims that even during the papacy of Liberos, the leavened bread was in use in the Catholic Church. However, when Philekos became Pope, who pontificated for eight years, and was an adherent of the dogma of Apollinaris in secret, that is, he believed that the body of the Lord [of Christ] was without a soul, he started to use azymes in the liturgy claiming that the Lord [Christ] had used unleavened bread for the first Eucharist. As time passed by, those who were under Rome [its ecclesiastical authority] have forgotten that it was a command of Philekos and not one of Saint Peter. ${ }^{422}$

How should this astonishing story be interpreted? The Catholic Church had not got any popes bearing the names of Liberos or Philekos. However, an important episode of church history was the conflict between Pope Liberius (352-366) and Antipope Felix II (355365). Felix was supported by Emperor Constantius II (337-361) who was sympathetic towards Arianism and preferred the more understanding Felix II to the strictly anti-Arian Liberius. Liberius was deposed by the emperor and banished to Berrhoia in 355, although his banishment was lifted by the emperor in 358 and he returned to Rome. ${ }^{423}$

Upon his return to Rome, the local populace forced Felix II out of the city and, although the successive imperial governments recognised him as pope until 365 , he had never returned the Eternal City anymore. It is worth mentioning, however, that Felix II was considered a legitimate pope from the $6^{\text {th }}$ century and even received his own feast day $\left(29^{\text {th }}\right.$ July). ${ }^{424}$

It is also worth noting remember that the Catholic use of azymes was linked to Judaism by the Orthodox, while Arian Christianity was often condemned by them for its alleged 'Judaising' practices. It could make it all the easier to link the pro-Arian Felix II to the initiation of the use of azymes into the Catholic Eucharist, which is obviously not certain, but a viable solution for the otherwise confuse and baseless story of Chomatenos.

Another important circumstance is that Emperor Constantius II is not mentioned at all by Chomatenos. The question is whether it is the consequence of his lack of knowledge about the role played by the emperor in the conflict between Liberius and Felix II, or it can be explained

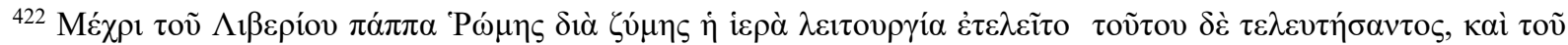

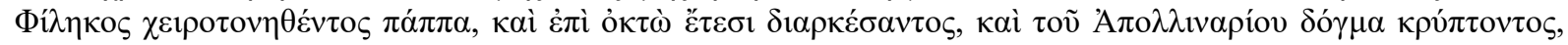

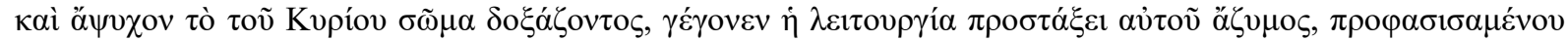

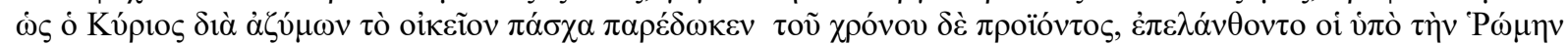

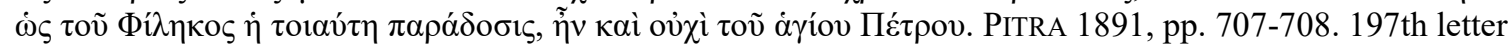

${ }^{423}$ HeIM, Manfred: Liberius. In CANCIK, Hubert-SCHNEIDER, Helmuth (Edd.): Der Neue Pauly. Enzyklopädie der Antike. Band 7. Metzler, Stuttgart-Weimar, 1998, p. 144.

${ }^{424}$ FrÖHLICH, Roland: Felix II. In CANCIK, Hubert-SCHNEIDER, Helmuth (Edd.): Der Neue Pauly. Enzyklopädie der Antike. Band 4. Metzler, Stuttgart-Weimar, 1998, p. 464.
} 
with the circumstance that the archbishop was aware of the deeds of Constantius II, but deliberately withheld the information.

If the latter case stands, the probable explanations for his decision can be 1) an avoidance of hurting possible Byzantine sensitivities, as Constantius II was a Roman (Byzantine for contemporary Byzantines) emperor, ruled from Constantinople and his father was Constantine I himself, 2) the story of a successful heretic conspiration to take over the Roman Church and warp it with 'obvious' lies could be seen as a more effective story by Chomatenos. This second explanation is supported by the circumstances that the version presented by the archbishop gave a reason to condemn the Latins as persons who became heretics and it was entirely because of their own extreme gullibility, while any mention of Constantius II could raise questions about imperial pressure playing a considerable role in the choice of 'erroneous' ways by the Latins, diminishing their responsibility as a logical consequence.

In any case, the Catholics are presented as adherents of clearly heretic practices and very gullible people simultaneously, misled by the astonishing lies of their pope, Philekos. In turn, the Orthodox believers are understood as followers of the right liturgical practice and sensible enough to avoid believing those 'Arian' lies. Two boundaries are presented: the one is of liturgical practice, while the other is rationality separating Catholicism and Orthodoxy in the story of Chomatenos, favouring Orthodoxy in both respects. These boundaries logically separate their Byzantine and Latin adherents too, and the evaluations of their respective denominations are transferred to both groups.

It is also important to address the accusation that the antipope was a cryptoApollinarian, who believed that the body of Christ did not contain a soul and, as his belief dictated that the Eucharist should happen with unleavened bread, he used mendacious claims about the Last Supper to introduce this practice into the Catholic Church. Historical evidence falsifies this part of the description presented by the archbishop, but certain details of the story help to give a possible reason for Chomatenos creating it.

Apollinaris, $4^{\text {th }}$ century bishop of Laodikeia taught that the body of Christ contained the Divine Logos itself instead of the human soul, which was condemned by the First Council of Constantinople (381) as heresy, while Apollinaris himself was declared a heretic, and his teaching was regularly distorted by Orthodox theologians as a claim about the Son occupying a lifeless body. ${ }^{425}$ Chomatenos here represents this theological current of contemporary Orthodox theology.

425 SMITH, Mahlon H.: And Taking Bread... Cerularius and the Azymes Controversy of 1054. Éditions Beauchesne, Paris, 1978, p. 137. 
However, the fact that Chomatenos wrongly gave the length of the papacy of 'Philekos', as eight years, while Felix II, who can be identified under this name, pontificated for ten years, strengthens the argument that Chomatenos lacked quality information regarding the events. Further support for this suggestion is provided by the Greek forms of the names Liberius and Felix ('Liberos' and 'Philekos') used in the letter. The question cannot be decided without doubt, but the explanations above seem to be the most probable ones, offering ignorance and/or deliberate falsification as reason(s) behind the story presented by Chomatenos.

There is one more letter in the corpus of Chomatenos dealing with question of azymes, which hits yet another tone. In this text, Chomatenos mentions the question of Mark, patriarch of Alexandreia, whose memory is holy. The letter is addressed to Theodoros Balsamon, blessed patriarch of Antiokheia, on a subject concerning Latin mercenaries [in Egypt], that is, whether they [the Orthodox clergy of the Patriarchate of Alexandreia] should continue to admit them [the aforementioned Latins] into the churches and allow them to receive the sacraments, as they intend to.

These lines refer to an incident that happened in 1190, when Mark III (1180-1209), patriarch of Alexandreia, addressed 66 questions to Theodoros IV Balsamon (1185-1199), patriarch of Antiokheia, including one on the further allowance of Catholics in Egypt to participate in the Orthodox Eucharist. Balsamon explicitly rejected the possibility of that, which Mark III refused to accept. The disobedient behaviour of Mark III led to strictures on the Church of Alexandreia for its alleged permissive stance on practices of Coptic origin, but Mark III maintained relationships with the Papacy until his death in $1199 .{ }^{426}$

Rather curiously, Chomatenos, although he comments on the arguments of Balsamon, does not mention the important details that Mark III refused to follow his verdict and the Church of Alexandreia was sanctioned for this in the upcoming years. He even praises Mark

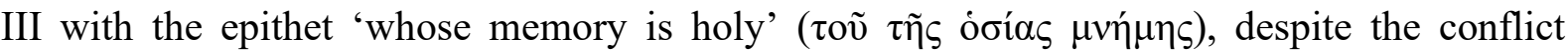
between the late patriarch and the hierarchies of Antiokheia and the imperial capital. In an apparent contradiction to the appreciatory epithet which he uses to Mark III, he also praises

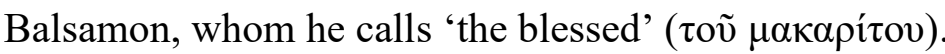

To explain these peculiar references of Chomatenos, it is crucial to consider a later part of the same letter. As he states, it is a tenable argument that if Latins come to them [the

\footnotetext{
${ }^{426}$ Runciman, Steven. The Eastern Schism. A Study of the Papacy and the Eastern Churches During the XIth and XIIth Centuries. Oxford, Clarendon Press, 1955, p. 99.
} 
Orthodox clergy] and want to receive the enzyma from them [the Orthodox], it makes it evident that they would not come to participate in the holy mysteries if they would not despise the azyma and if they would not hold it precious to respect those [the enzyma]. ${ }^{427}$ It supposes a dichotomy, in which a Christian either rejects the use of unleavened bread in the Eucharist and supports the use of leavened bread instead or does the exact opposite, not leaving any middle ground.

In this model, the practice of the azymes is once again presented as wrong, contrasted with the enzymes, which appears as right, and they establish a striking contrast between Catholicism and Orthodoxy. This contrast also influences the image of the Byzantines, who are to be understood as followers of the 'right' practice and most Latins, who are featured as followers of a 'wrong' practice, envisioning a considerable difference between them in respect of religion, which favours the Byzantines. Yet, this religious difference is not bound to ethnicity, as Latin mercenaries in Egypt, willing to participate in an orthodox Eucharist, are claimed to be willing to reject the azymes and accept enzymes, moving themselves closer to Orthodoxy, and so to the Byzantines, too.

However, such an intention can hardly be appropriated to the Latin mercenaries in question. The Catholic Church taught that both leavened and unleavened bread were acceptable for the Eucharist, as the text of the Bible merely stated that Jesus used bread for the Last Supper, without any further concretisation. ${ }^{428}$ In the mirror of this, Catholics willing to participate in an Orthodox Eucharist maybe just regarded it as an acceptable Eucharist if receiving a Catholic one was not possible and did not care with the liturgical difference, if they knew about it at all, which should have been evident for archbishop Chomatenos.

However, Latins willing to participate in Orthodox Eucharists could have been a recurring phenomenon in territories of the Latin Empire which were under the Orthodox ecclesiastical jurisdiction of Chomatenos. The metropolitan probably also understood that rejections of such requests made by the Latins would provoke conflicts between the Orthodox and the Catholic populations, resulting in avoidable suffering for the Orthodox communities involved. Placating Orthodox aversion of the Latins receiving the Eucharist provided an effective and theologically acceptable way of avoiding such conflicts, while lessening frustration among the Orthodox population at the same time.

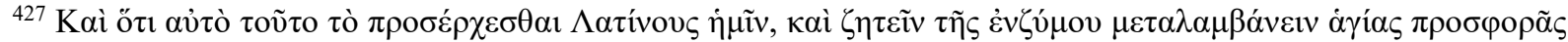

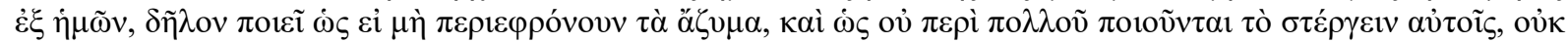

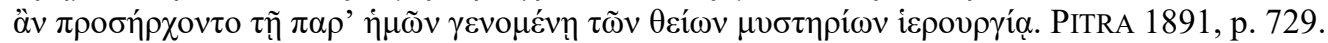

${ }^{428}$ AVVAKUMOV 2002, pp. 146-148.
} 
It is probable that such concerns influenced Chomatenos, when he, although mentioning the authoritative verdict of Theodoros IV Balsamon, whom he praised, also wrote with a remarkable respect about his opponent, Mark III, and held up the optimist explanation on the behaviour of Latins willing to take part in the Orthodox Eucharist. Yet a wider context of the analysed sources unfolds, presenting a high priest who seemingly voices contradictive opinions about the very same theological question hitting a scale of different tones. These contradictions disappear if we regard these opinions as representations carefully tailored to certain situations. Apparently, Chomatenos was adept not only in canon law but also in diplomacy.

\section{VII.2. Conclusion}

It is remarkable that all the five letters that mention the question of azymes in the Eucharist are from the correspondence of a sole person, archbishop Demetrios Chomatenos. The limited number of sources and their common author suggests against deriving any general conclusion about the representation of azymes in Late Byzantine epistolography, except for perhaps its seemingly limited importance compared to other subjects related to the Latins within the genre.

The evaluation of the views displayed by Chomatenos proves to be a task less complicated. His letters dealing with the subject occupy a highly critical stance towards the Latin practice, except for one that argues for the validity of the use of azymes in the Eucharist, standing in an astonishing contrast to the other ones. Striking are the anti-Semitic allusions and the historical conspiracy theories promoted about the origins of azymes in the Catholic Eucharist by the author, especially as it is questionable if Chomatenos himself had actually believed these stories, because he was an eminent Orthodox theologian and canon jurist.

There is more than one explanation for the divergent views on the subject preserved in the letters of Chomatenos. It is possible that he changed his opinion in respect of unleavened bread, the unknown chronology of his letters making it impossible to reconstruct the direction of this change if one adheres to this theory. Nonetheless, his long career as an Epirote political personality who could swiftly adapt to changing situations and the supposable long-term considerations behind his words arguing for the permission of Latins participating in Orthodox Eucharists do allow another explanation. It is also plausible that the views of Chomatenos had not changed at all by time, but he adjusted his argumentation to the audience 
and his own very aims. If this is a possible case, then his arguments on azymes represent examples of a theological debate becoming intertwined with politics, as it so often happened in medieval times. 


\section{The Filioque-Controversy}

Perhaps the greatest source of dissonance between the Catholic and the Orthodox churches was the so-called Filioque-controversy. The Nicaean Creed stated that the Holy Spirit proceeded from the Father. However, in 589, at the Third Council of Toledo, the church in the Iberian Peninsula adopted an addition, the Filioque, which version stated that the Holy Spirit proceeded from the Father and the Son. This version became the standard in the Christian West, but the Eastern rite kept the original version of the creed. Polemics started when Frankish missionaries started to use their version of the creed in $9^{\text {th }}$ century Bulgaria and the problem escalated in the following centuries. The Filioque was one of the main reasons behind the Schism of $1054 .^{429}$

\section{VIII.1. Denial}

Barlaam Kalabros, in a letter written to Gregorios Palamas, presents some interesting references to the Latins, although the main concerns of the text are their theological differences with Palamas. Barlaam states that nobody among the Latins dares to say that the Holy Spirit has two principles or [dares to say] that 'a first and second principle' or that 'one of the two principles that go together'. ${ }^{430}$

According to him, certain Greeks voice such things as 'how ridiculous it is, oh, Latin, that you say that you think principle to differ from principle and yet [you] talk about two principles. ${ }^{431}$ As Barlaam states, his holiness [Palamas] himself knows what kind of things the Latins say for their defence to those who accuse them with differentiating two principles [of the Holy Spirit]. ${ }^{432}$

At this point, Barlaam sees it adequate to conclude and evaluate some beliefs of Palamas. The third of these, which is related to the Filioque, is that Palamas states that it is impossible to call two principles one principle, if one of them comes from the other. This

\footnotetext{
${ }^{429}$ MEYENDORFF, John: Filioque. In KAZHDAN, Alexander - TALBOT, Alice-Mary (Edd.): The Oxford Dictionary of Byzantium. Oxford University Press, 1991. pp. 785-786.

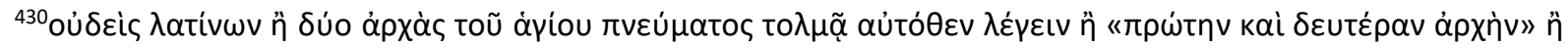

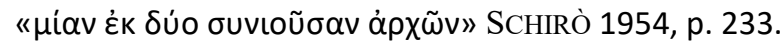

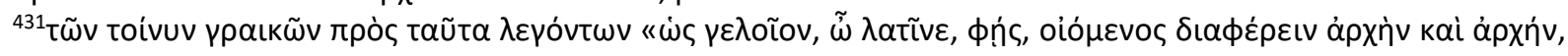

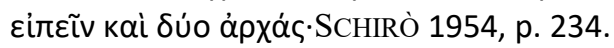

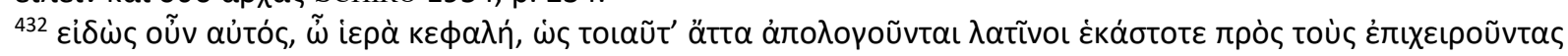

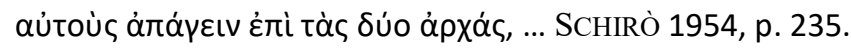


third one of the three is true but has nothing to do with the Latins. ${ }^{433}$ Barlaam notices three problems with this argumentation. First of these, and the relevant one for this study, is that Palamas slanders the Latins, as they do not claim that [the Holy Spirit] has two origins. ${ }^{434}$ Finally, Barlaam states that the Latins say that nothing hinders to express that the Father is the sole source of divinity and the Holy Spirit proceeds from the Father through the Son, as he himself [Barlaam] demonstrated it above. ${ }^{435}$

The remarks of Barlaam about the Filioque are rather characteristic to the arguments of those Orthodox theologians who advocated an open-minded attitude towards the Latin understanding of the Holy Trinity. He denies that the Latins would teach that the Holy Spirit has two principles, the Father and the Son, but they teach that it proceeds from the Father through the Son. He also politely disparages Palamas and other, unnamed Orthodox critics of the Filioque for being slanderous and condescending toward the Latins, and not caring about the arguments the Westerners invoke for their own defence, although they are very much aware of these apologetics.

As the reality of Roman Catholic teaching of the dual procession of the Holy Spirit could expect little tolerance from hard-liner Orthodox theologians, their pro-Latin counterparts showed a tendency to misinterpret the Filioque in the Latin creed as if it meant that the Father proceeds the Holy Spirit through the Son. A few Orthodox authorities, including Gregorios the Wonderworker, Gregorios of Nyssa, Basileios of Kaisareia and Kyrillos of Alexandreia, presented quotes that supported such an understanding of the procession of the Holy Spirit. ${ }^{436}$ However, as this argument relied on a fraudulent interpretation of Catholic dogma, it could have only limited success, especially against Orthodox theologians who were adept in Catholic teachings.

The arguments of Barlaam also have important implications regarding the image of Latins and Byzantines. Orthodoxy and Catholicism are presented as teaching essentially the same about the origins of the Holy Spirit, thus eliminating the traditionally most serious dogmatic difference between them, portraying the two denominations as standing much closer

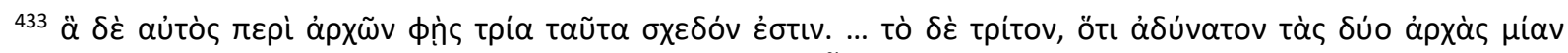

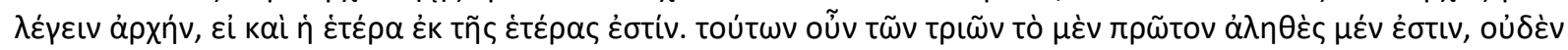

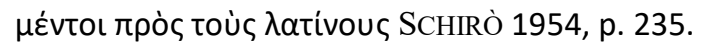

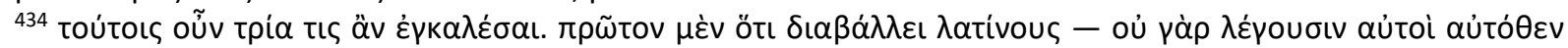

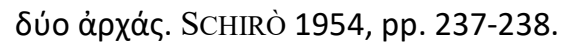

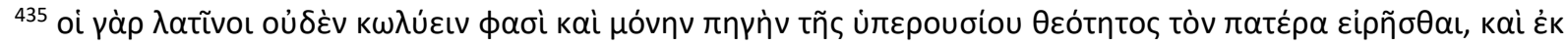

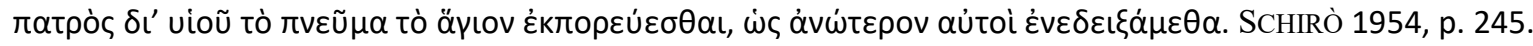

436 BÖHNKE, Michael - ASSAAD, Elias Kattan - OBERNDORFER, Bernd (Eds.): Die Filioque-Kontroverse : historische, ökumenische und dogmatische Perspektiven 1200 Jahre nach der Aachener Synode. Herder, Freiburg - Basel - Wien, 2011, pp. 306-307.
} 
to each other than it was traditional in Byzantium. Logically, it affects the boundary between the Latins and the Byzantines in the field of religion; thus, greatly reducing the distance between the two ethnicities.

It is also remarkable that a particular moral difference is envisioned between Catholic and Orthodox theologians, and it is suggested that the latter group includes many people who are utterly prejudiced against the Latins, adamant in their false view that the Catholic teaching on the procession of the Holy Spirit is wrong and unwilling to even listen when Catholic theologians try to explain their dogmas on the subject.

\section{VIII.2. Condemnation}

Numerous letters under scrutiny prove that the attitudes of Barlaam regarding the Filioque were rather far from common among Byzantine theologians. For instance, Gregorios Palamas himself, in a letter addressed to Akindynos, accuses the debaters of the Latins with establishing two origins for the divinity of the Holy Spirit, namely the Father and the Son, teaching that it [the Holy Spirit] is from both. ${ }^{437}$ He warns Akindynos that he should know exactly and as unalterable, that this [the Holy Spirit proceeding from the Father and the Son] was the doctrine of the Latins and in this [question] one has to oppose them [the Latins] with the resistant strength, if one does not want to waste away the strength [of one] in peaceful times, and find oneself inferior in emergencies. ${ }^{438}$

Palamas even asked an ironic rhetorical question about how it is that, according to the Latins, the two principles of the one Holy Spirit are one principle? ${ }^{439}$ It was followed by another ironical question, asking if it is not so according to the Latins that the procession is shared by the Father and the Son, as the Father sends out the Holy Spirit with an intermediary, while the Son does that without an intermediary, so they [the Latins] say that the Son possesses the productive [quality] as a person, then, according to them [the Latins], the

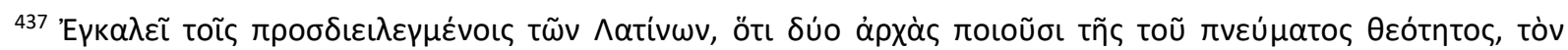

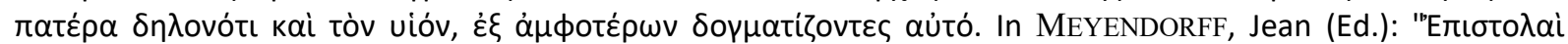

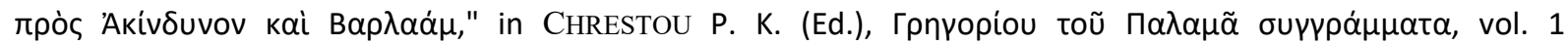
[Thessalonike 1962]: 203-312. p. 203. Henceforth MEYENDORFF 1962.

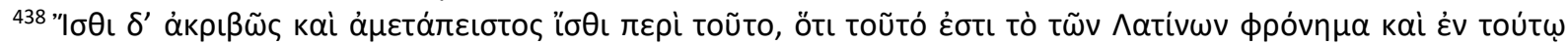

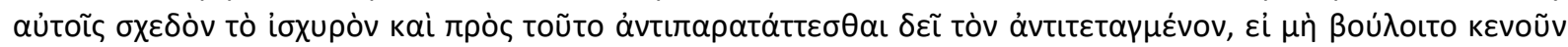

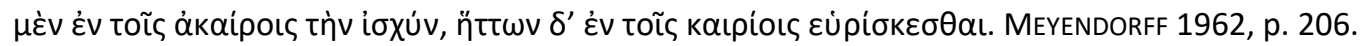

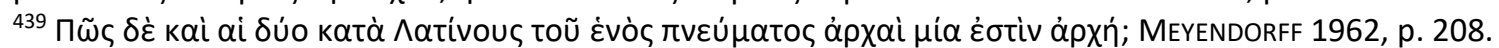


creative quality and the sanctifying quality, and simply all the essential things are not shared by the Father and the Son? ${ }^{440}$

Palamas adequately addresses the problem with the tendentious pro-Latin misinterpretation of the Filioque, making it clear that he will not be misguided by such spins. He also underlines the necessity for the Orthodox believers to resist such teachings vehemently even when the Latins cannot pressure them, or else they may lack the tenacity to resist this teaching when the Latins can use force to make them accept the Filioque.

Such a theologically aware, strictly rejective and alarmist attitude toward the Catholic teaching of dual procession made it virtually impossible to convince Palamas, and he was very far from being alone with these characteristics among Byzantine theologians. Furthermore, the teaching of Palamas about uncreated divine energies provided anti-Latin theologians with effective counterarguments against pro-Latin claims, which alleged that references of Orthodox authorities supporting the procession of the Holy Spirit from the Father through the Son would also support the Filioque. ${ }^{441}$

To assess the portrayal of the Latins by Palamas, they are presented as adherents of the Catholic dogma of the dual procession of the Holy Spirit, which is rejected as obviously false. It leaves the Westerners as a group committed to a false dogma, while the Orthodox teaching of the subject is implicitly understood as right, making its Byzantine adherents believers of the 'correct' opinion on the subject, establishing a considerable religious difference between them, with an evaluation that logically favours the Byzantines. In this context, the behaviour of the apologists of the Latins proves very questionable, as they intentionally try to camouflage a false teaching as an acceptable one, establishing a moral division between the Byzantine community, implying the anti-Latins as more moral persons.

Gregorios Palamas, likewise writing to Gregorios Akindynos, commented on the origin of the Holy Spirit. As he stated, to conclude syllogistically the issue regarding such things [the origin of the Holy Spirit], they [the Orthodox] learned [it] from the Fathers and nobody would write about the Latins for this [subject]. ${ }^{442}$

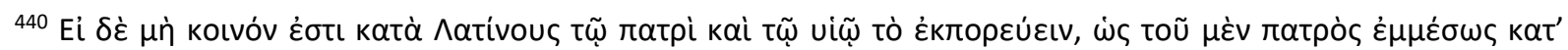

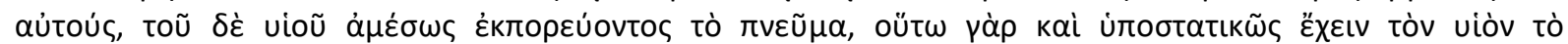

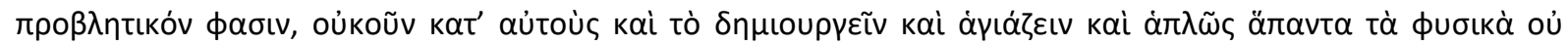

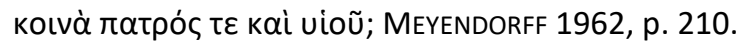

441 SIECINSKI, Anthony Edward: The Filioque: History of a Doctrinal Controversy. Oxford, University Press, New York - Oxford, 2010, pp. 146-147.

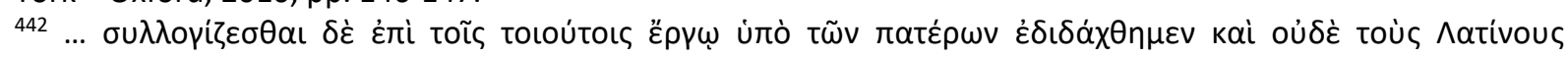

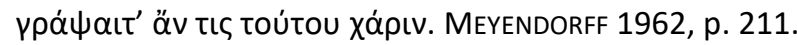


The above statement of Palamas expresses an arrogant confidence in the validity of the Orthodox teaching on the origin of the Holy Spirit. The Orthodox are claimed to have learned it from the Fathers, which serves as its sole validation, providing an argument based on nothing else but authority.

The Catholic point of view, the Filioque, is swiftly dismissed by the author, claiming that nobody would write about the Latins for this subject. The Latin view is implicitly branded as invalid without any further explanation, suggesting it being an evidence for any learned and faithful Orthodox believer, who is easily identifiable with the group of those who would not write about the Latins for this subject.

The words of Palamas mirror his attitude regarding theological truth. He understood Orthodox theology as a field of apodictic, demonstrably or self-evidently true, statements, due to the blessing of revelation through the Bible and other sources, including the Orthodox Fathers. ${ }^{443}$ This teaching granted dominance to authority and resulted in a negligible chance for any theological compromise.

Similarly writing to Akindynos, Palamas claimed that it was among the most important things to confute the things of the Latins in the answer [addressed] to them, [which] was skilfully fit with words. So, his things [the ones of Palamas] addressed to them [the Latins], that were plainly demonstrated earlier above, were dealing with the insolence [of the Latins], and he [Palamas] did not hope that the Latins themselves would take his things [the ones of Palamas] with silence, but they [the Latins] were expected for him [Palamas] to speak against [the things of Palamas]. ${ }^{444}$

The things of the Latins and their alleged insolence are rather obscure expressions in themselves, but the letter provides the analysis with the necessary context, as its main concern is the opposition of Palamas to Barlaam and his alleged support for the Catholic teaching of the Filioque. In the course of their debate, Palamas began to interpret the attempts of Barlaam to harmonise the Catholic and Orthodox views on the procession of the Holy Spirit as a

\footnotetext{
443 PODSKALSKY, Gerhard: Theologie und Philosophie in Byzanz. Der Streit um die theologischr Methodik in der spätbyzantinischen Geistesgeschichte (14./15. Jh.), seine systematischen Grundlagen und seine historische Entwicklung. Byzantinisches Archiv 15. C. H. Bech'sche Verlagsbuchhandlung, München, 1977, p. 152.

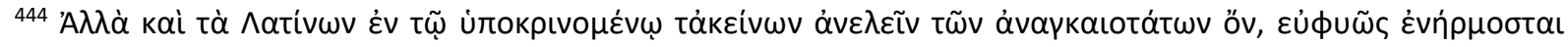

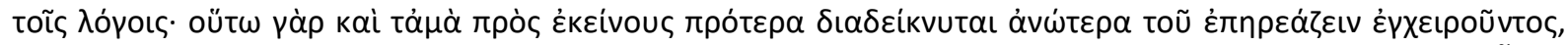

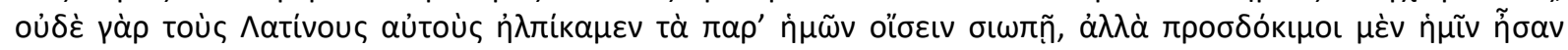

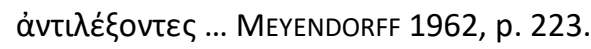


deceitful attempt to feign the defence of the respective Orthodox dogmas, while in fact defending the Catholic teaching of the dual procession. ${ }^{445}$

Regarding these aspects, the things of the Latins are identifiable with the dogma of dual procession and possibly any related Catholic teachings, while their insolence may refer to these beliefs or to these beliefs and the Latin attempts to convince the Orthodox believers about them. The difference perceived between the Latins and the Byzantines is of religious nature, more precisely, their different views on the origin of the Holy Spirit.

These divergences are portrayed as profoundly important ones by Palamas, while he implicitly claims the respective Orthodox teaching to be 'valid' and the Catholic teaching to be 'invalid', through his claim that it was most necessary to refute the latter one. He

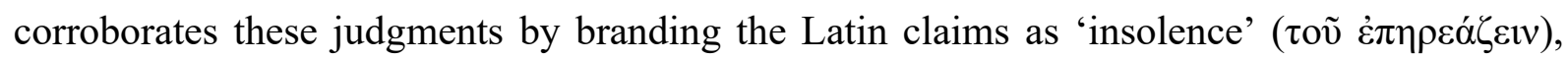
suggesting them being false and any attempt to spread them as a shameful act.

However, Palamas also stresses his expectance of further arguments from them, claiming that he did not hope that the Latins would remain silent after his refutation. It points to a group that is unwilling to accept itself being at fault and ready to attack refutations against its arguments, suggesting community which is irresponsive to criticism to a relatively high degree.

Palamas also voiced his criticism of the dual procession to Barlaam Kalabros. In a letter addressed to his theological opponent, Palamas states that as soon as he will hear that they [the Latins] talk about one divine source, one principle and one God-creator divinity and [Palamas will hear] that those who voice these [beliefs] are worshipped even among the Latins, he will discuss with them [with the Latins] those [Orthodox beliefs] that are [otherwise] accepted for the Latins. ${ }^{446}$

Palamas asks the question why it is so that whenever they [Palamas and his supporters] say that all Persons of the Godhead are causes and principles of the things that exist, but nonetheless the cause and principle of the things that exist is one, he [Barlaam] says that it is true and it supports the Latins? Because if the truth supports those [the Latins], who will convert those who are supported by the truth? ${ }^{447}$

\footnotetext{
${ }^{445}$ FYRIGOS, Antonio: Dalla controversia palamitica alla polemica esicastica (con un' edizione critica delle Epistole greche di Barlaam). Antonianum, Roma, 2005, p. 70.

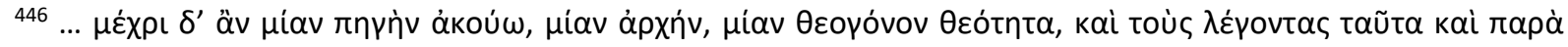

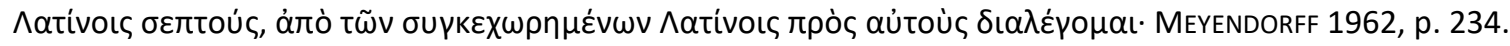

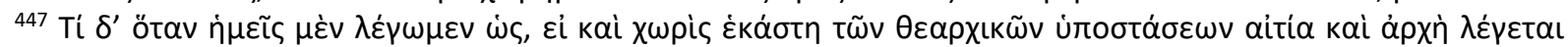

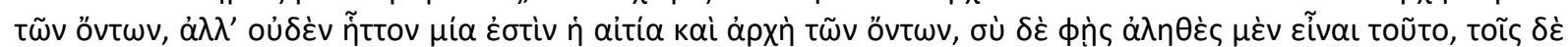


Gregorios Palamas soon continues that when they [Palamas and his supporters] say that the Father creates everything through the Son in the Holy Spirit, the principle of everything is one, he [Barlaam] instantly claims that the Latins say so too that the Father sends out the Holy Spirit through the Son, hereafter, there is one principle of divinity. ${ }^{448}$

Finally, he delivers a condemning verdict on the interpretation of the Latin creed on the Filioque proposed by Barlaam. As Palamas states, if the Latins claim the same talking in public about the highest Trinity, they [Palamas and his supporters] will refute them, putting forth the divinely inspired writings, and besides demonstrating that they [the Latins] suppose two Holy Spirits, with which they turn the uncreated Trinity into a Quaternity. ${ }^{449}$

Such references once again underline that Palamas and many of his supporters were perfectly aware of core Catholic teachings, rendering any effect of tendentious pro-Latin misinterpretations of the Filioque rather limited. Palamas underlines that he and many Orthodox theologians supporting him understand the meaning of the Filioque and cannot be misguided about it. He also invokes the authority of the Orthodox theological tradition on this subject to make his point.

A remarkable curiosity among his remarks is the claim that the Latins suppose two Holy Spirits, one proceeding from the Father and one proceeding from the Son. It seems to be a reductio ad absurdum of the Catholic teaching on the procession of the Holy Spirit, maybe as a response for the attempt of Barlaam Kalabros to convince him with a deliberately false interpretation of the Filioque.

The claim that Catholicism supposes a Holy Quaternity, which is judged as evidently false, combined with the tacit, yet palpable conviction in Orthodoxy being right about the origin of the Holy Spirit, establishes a strong boundary between the two denominations. This fact affects the relationship envisioned between their respective Latin and Byzantines followers too, establishing a chasm between them in the field of religion, and granting the higher standing for the Byzantines.

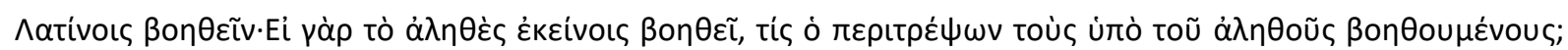
MEYENDORFF 1962, p. 235.

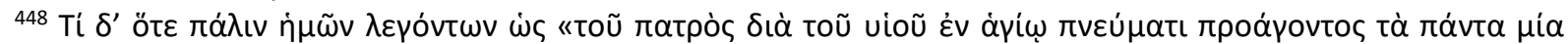

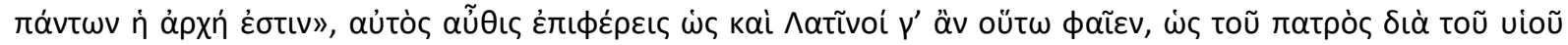

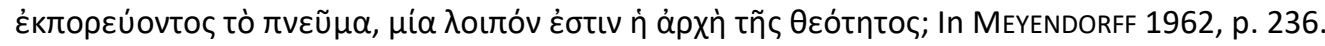

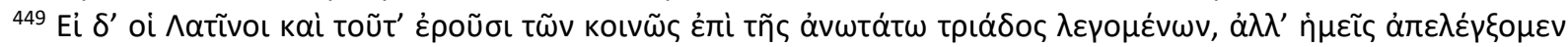

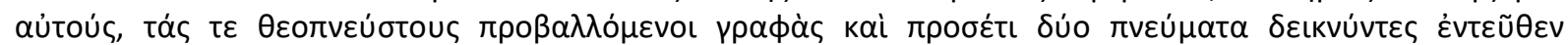

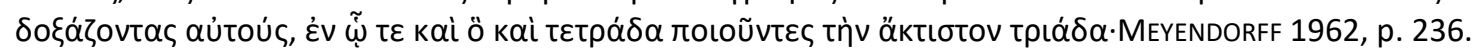


Palamas, writing to Barlaam, claims that he [Barlaam] had showed it through a marvellous accusation that the Latins making the bad worse. ${ }^{450}$ Latins in this remark appear as a group who are already facing an adverse situation, but they only exacerbate the existing problem with their reaction. Barlaam, here accepted as a Byzantine Orthodox by Palamas, is depicted as a person who was able to identify and expose the sorry situation of the Latins, while Palamas himself is also understood as someone capable of realizing the validity of his accusation, now praising the charge.

Regarding the unfolding conflict between Palamas and Barlaam, this praise may have an ironic overtone, instead of reminding Barlaam to views that seem to provide a common point for him and Palamas. Addressing the question of the presence of ethnic boundaries in the remark, interpreted without context, the text suggests Western incompetence, in comparison with Byzantine competence, as both Barlaam and Palamas are presented as persons being capable of realizing the unprecise Western failure.

However, it may be possible to decipher what Palamas meant by the Latins 'making the

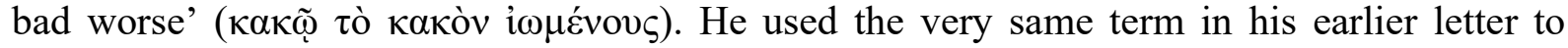
Akindynos and Barlaam, commenting on the dogma of the dual procession of the Holy Spirit. Palamas praised Barlaam for condemning the teaching of the dual procession earlier and presenting another Catholic dogma, namely that there was still one God and one divine principle, as one that creates yet another problem, logically through its perceived contradiction to the meaning of the dual procession, and disparaging it as 'making the bad worse'. ${ }^{451}$

Yet, it does not make it necessary that Palamas referred to the same question using the same figure of speech. If he did, his words were a reiteration of his views on the remarks of Barlaam regarding the Catholic dogmas of the dual procession and the existence of only one God and one divine principle, the first being an 'erroneous' teaching and the second one being 'true', but 'contradicting' the former one.

In that case, Palamas addressed a religious boundary between the Latins and the Byzantines in the form of the origin of the Holy Spirit. The Latin dogma of the dual procession is understood as wrong and heretical, while the Orthodox teaching is accepted as right and faithful, granting Orthodox Byzantines a higher standing in the field of religion than Westerners, a common idea in Late Medieval Byzantium.

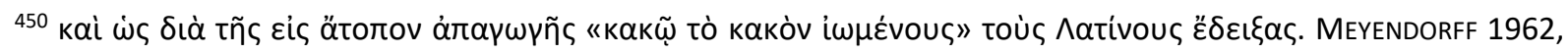
p. 225.

451 In MEYENDORFF 1962, pp. 203-204.
} 
It is more surprising that the circumstance that the Latin shared the Byzantine faith in the existence of one God and one divine principle is interpreted as casting negative light on Catholics. The reason for this is its perceived contradiction to the teaching of dual procession, making Latin theology not simply wrong and heretical in certain aspects, but also confused according to Palamas.

Palamas also states that he has nevertheless received the apology that [Barlaam] hold out [as an excuse], although it was bitter and propounded those things of the Latins that were refuted by him [Palamas] on many occasions as if [these things] had not been refuted. ${ }^{452}$ It is not immediately evident what Palamas means by the things of the Latins that had been already refuted by him. But, regarding the subjects of his debate with Barlaam and Akindynos, they are evidently to be understood as religious dogmas. And indeed, the part of the letter containing these remarks is once again concerned with the dogma of dual procession, that is, the Filioque.

Therefore, the main difference between Latins and Byzantines in this representation is defined by their respective religious beliefs. These are not clearly defined but other parts of the source make them identifiable with the teaching of dual procession, professed by the Catholics, and the Father being the sole source of the Holy Spirit, professed by the Orthodox.

According to the representation of Palamas, these differences should be regarded as already satisfyingly decided. The nature of this decision is evident: the teaching of the dual procession is portrayed as successfully refuted on multiple occasions by Palamas, which statement invokes the image of a triumphant Byzantine Orthodoxy, theologically 'correct' regarding the origin of the Holy Spirit, and a defeated Catholicism, 'wrong' about the same subject.

At the same time, the figure of Barlaam is featured as a man who presented the Latin views concerning the origin of the Holy Spirit to Palamas as ones that have not been refuted exactly by him. It appears as a necessarily vain attempt, while it also suggests that Barlaam has a rather limited knowledge both about theology and about his opponent, which is amplified by the ironically condescending tone of Palamas.

A remark of Palamas in the very same letter, and not much later in the text, also admonished [Barlaam] not to think him [Palamas] unaware of how false those statements and

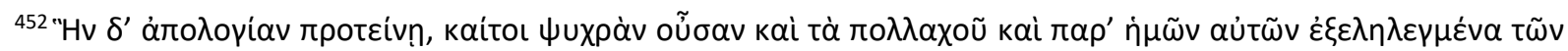

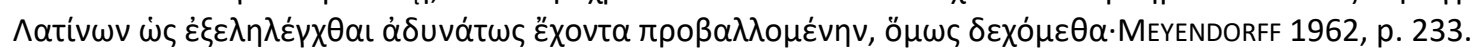


dogmas are, because they are from the Latins. ${ }^{453}$ As Barlaam had deliberately misrepresented the Catholic teaching of the Filioque to him, Palamas had the reason to point out his awareness of Catholic dogmas to his opponent and so demonstrate the futility of the attempt made by Barlaam to mislead him.

Regarding the Latins, Palamas once again focuses on religious difference, which is, regarding the context, clearly identifiable with the Catholic teaching of dual procession and certain undefined dogmas intricately connected to it. These dogmas are depicted as not simply false but very distant from theological truth by Palamas, while his own view, that is, the Orthodox teaching on the origin of the Holy Spirit and certain undefined, connected dogmas, is implicitly taken as 'correct', which once again reinforces Byzantine religious supremacy over Latins.

Meanwhile Barlaam is tacitly accused of being aware of the falsehood of these Catholic teachings. It is an obvious attack on the bona fides of Barlaam, accusing him of knowingly promoting theologically 'erroneous' teachings, a serious sin according to contemporary Orthodox morality. Palamas appears as the selected victim for the ruse, who proved to be more aware than Barlaam supposed, turning the table and pointing out this attempt to fool him.

An interesting detail is the charge made by Palamas that Barlaam thinks that because those teachings come from the Latins, Palamas may be unaware of their false nature. It suggests that the Latin nature of these dogmas constitutes a barrier towards knowing them. Logically, it may be geographical or linguistical in nature.

However, Latins were very much present in the Byzantine world in the era of Palamas, so the first option is hardly tenable, which points to the implicit underlining of a linguistic difference, which may prevent Orthodox theologians to be aware of Catholic teachings. Palamas himself appears as someone who either successfully bridged this barrier through his command of Latin or came round it with the help of his paideia, boosting his standing as a theologian.

Palamas, writing to Barlaam, asks ironically, if it was the most useful [action] for him [Barlaam] to demonstrate all the speeches of the Latins that were put forward syllogistically for their own dogma, having the premises that are equally in question in regard to their

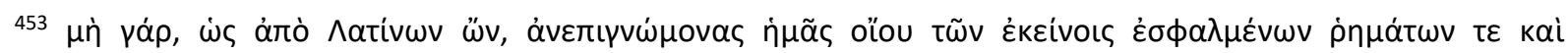

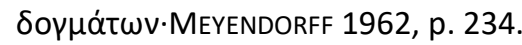


conclusion, and is [Barlaam] anxious lest those who utter these syllogisms may call the dialectic ones apodictic ones and put him [Barlaam] into extreme difficulty? ${ }^{454}$

Such a representation suggests that the Latins are theologically erroneous and failing in their logic, as they have formed the syllogisms of which both the premises and the conclusions are debatable. The impression of Latin failings in logic is enhanced by the sarcastic image of Barlaam being afraid that those who tell these syllogisms happen to mistake apodeictical and dialectical syllogisms, suggesting a very limited philosophical erudition.

The differences between the Latins and the Byzantines stressed by Palamas are theological and cultural. If Latin syllogisms about their dogmas are flawed, then their dogmas are most probably flawed too. Such grieve logical errors also point to problems with erudition, which impression is effectively enhanced by the image of Latin theologians being unable to differentiate apodeictical and dialectical syllogisms.

It is important, however, to underline that Barlaam and Palamas regarded the use of apodictic and dialectic syllogisms in theology very differently. In classical Aristotelian logic, apodictic propositions are demonstrably or self-evidently valid, while assertoric propositions merely assert the validity of a claim, and problematic propositions only assert the possibility of the validity of a claim. Apodictic syllogisms can be constructed relying on apodictic propositions, while dialectical syllogisms are made possible by the two latter types of propositions.

Barlaam argued that it was impossible to obtain certain knowledge about God, so, dialectic syllogisms were valid in the field of Trinitarian theology. However, according to Palamas, thanks to the blessing of revelation through the Bible and other holy sources, the eternal and immutable divine sphere should be reserved for apodictic syllogisms, while dialectic syllogisms should be made about the transient and mutable world. ${ }^{455}$ This principle of Palamite theology logically inhibited theological development and extremely limited any possibility of theological compromise.

Palamas states that as he himself [Barlaam] says, he [Barlaam] nevertheless supposed that the syllogisms presented to him by the Latins are not open to attack, as the traditions of the

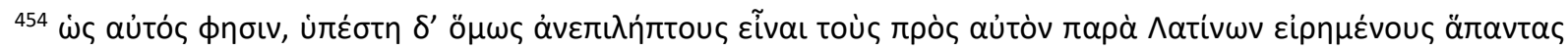

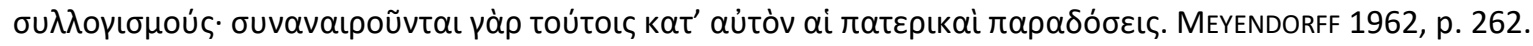

455 PODSKALSKY, Gerhard: Theologie und Philosophie in Byzanz. Der Streit um die theologischr Methodik in der spätbyzantinischen Geistesgeschichte (14./15. Jh.), seine systematischen Grundlagen und seine historische Entwicklung. Byzantinisches Archiv 15. C. H. Bech'sche Verlagsbuchhandlung, München, 1977, pp 150-152.
} 
Fathers give the same answer as they do [the syllogisms presented to the Latins]. ${ }^{456}$ These remarks of Palamas, once again, implicitly point to the existence of a strong religious boundary between the Latins and the Byzantines.

The behaviour confessed by Barlaam, more precisely, that he treated the Latin claims as ones above criticism due to their accord with the Orthodox Fathers, could only be problematic, if there was a reason to question their accord with the Orthodox Fathers and so their theologically unassailable nature. It was exactly the case, regarding the already centuries-old schism between the two Churches.

As the main theological concern of the letter is the Filioque, the alleged questionable decision of Barlaam had to be understood as his acceptance of the Latin syllogisms about the dual procession as valid and as ones in accord with Orthodox religious authorities. Accepting the dual procession as valid would have meant the rejection of a key Orthodox teaching, but thinking that this dogma was supported by the Orthodox Fathers would have constituted another serious theological error according to contemporary Orthodox theology.

However, Palamas here misrepresents the claims of Barlaam, as Barlaam did not argue for the validity of the dual procession, but promoted the view that Catholicism originated the Holy Spirit only from the Father, as Orthodoxy did, merely claiming that the procession of the Holy Spirit from the Father happened through the Son. It was a deliberate misrepresentation of Catholic teaching, followed by the aforementioned, and possibly also deliberate, misrepresentation committed by Palamas.

Palamas also says that [one of his earlier writings] refutes the Latins not otherwise but by the stating of their syllogisms being neither dialectical nor apodeictical according to the Aristotelian traditions. ${ }^{457}$ This statement supposes a difference between Byzantine and Latin erudition. Aristotelian logic is established as a system which is both valid and worthy of serving as a standard, while Latin syllogisms are depicted as failing to fit into its categories, logically because of their flawed nature. Regarding that a Byzantine, Gregorios Palamas, appears as capable to diagnose this grave problem, evidently relying on his Byzantine erudition that included Aristotelian logic, a difference or niveau can be supposed between Byzantine and Latin culture on the basis of his presentation.

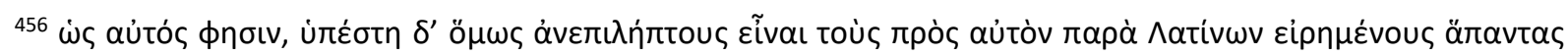

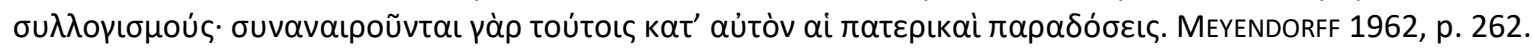

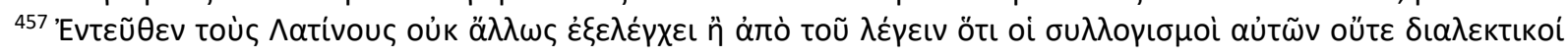

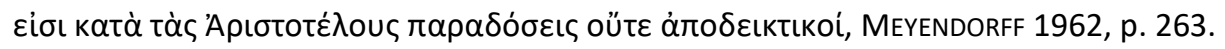


After Barlaam Kalabros had left for Italy and finally had even become the Catholic bishop of Gerace, ${ }^{458}$ Gregorios Akindynos became the leading figure of the anti-Palamite opposition. But long before that, at the early phase of the conflict between Barlaam and Palamas, in the summer of 1336, Akindynos addressed a letter to Gregory Palamas, countering the charges of the Hesychast leader against Kalabros.

As Akindynos writes, their entire effort and task [of the writings of Barlaam] is the refutation of the Latin dogma that the Holy Spirit proceeds from the Son also, the best as they can do it. Thus, how would it be possible for these [the writings of Barlaam] to hypothesize the Son to be a principle of the Holy Spirit? ${ }^{459}$

The works of Barlaam that Akindynos refers to are his 21 anti-Latin treatises, which, as Meyendorff describes them, present their reader with strongly anti-Thomist theological views, often criticising the Catholic teachings on the origin of the Holy Spirit, arguing for the validity of the Orthodox teaching on the subject. ${ }^{460}$

These tractates indeed spoke for the claim that their author adhered to the rejective Orthodox stance towards the Filioque. So, the reliance of Akindynos on the previous deeds of Barlaam Kalabros to argue for him being a convinced Orthodox, finds a solid basis in them. Such an argumentation decapacitates Palamas to confirm his criticism of Kalabros, but to prove that Barlaam changed his mind since he had written his works, or, which is even more problematic, to argue that he publicly represented the Orthodox teachings although they contradicted his own views.

The argumentation of Akindynos is not so protective towards the Latins. The Catholic dogma of dual procession is evaluated as wrong, with the competing Orthodox teaching clearly regarded as right. It leaves the Latins once again as adherents of a false belief, while the Byzantines profess the correct views, establishing a huge Byzantine advantage in the field of religion.

The criticism of the Filioque are not restricted to letters from the fourteenth century in the analysed corpus. Symeon of Thessalonike (1381-1429), metropolitan archbishop of his eponymous city, condemned the Filioque in his dogmatic letter addressed to an unknown

\footnotetext{
${ }^{458}$ RunCIMAN, Steven: The Great Church in Captivity: A Study of the Patriarchate of Constantinople from the Eve of the Turkish Conquest to the Greek War of Independence. Cambridge University Press, 1986. p. 142.

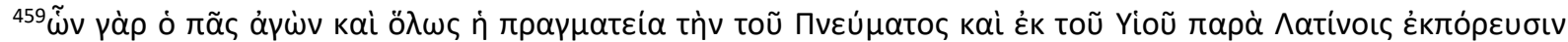

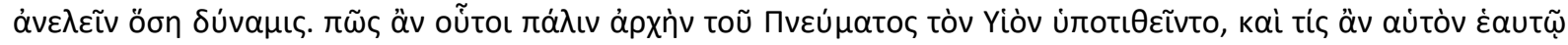

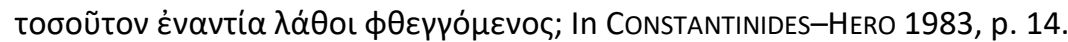

460 MeyendorfF, Jean: L'origine de la controverse palamite. La première lettre de Palamas à Akindynos. Theologia XXV (1954), Athens, pp. 602-630, pp. 604-610.
} 
Cretan Orthodox. Continuing his previous train of thought, he claims that whenever his addressee hears [from the Latin clerics] that the Holy Spirit is given, sent, dispatched, poured out and provided and to think about the gift and grace of the Holy Spirit, which is common and of the Holy Spirit itself, of the Father and of the Son, then, that is what caused the going astray among the Latins. ${ }^{461}$

This argument fits into a presentation of broader focus about the alleged preaching of Latin clerics in Crete that is uncompromisingly reproachful towards the Filioque, even without explicitly naming it, and it was evident for a presumable, relatively educated Byzantine audience. The numerous epithets of the Holy Spirit create the atmosphere of a verbose predication, culminating in a hortation, attributed to the Latin preachers: the addressee should think about the gift and grace of the Holy Spirit, which come directly from the Holy Spirit, and indirectly from the Father and from the Son.

This latter claim, besides invoking an impression of Latin proselytising, also points to the Filioque, upon which such a claim could rely. Symeon of Thessalonike swiftly condemns this Catholic dogma as the cause of going astray among the Latins, branding it as a false teaching that leads to errands. In this context, Catholicism follows a 'false' dogma in a cardinal question, while Orthodoxy is to be understood as the faith promoting the 'right' belief about the subject, separating the two denominations from each other.

It also has the implication that the Latins and Byzantines, followers of these two faiths, are supposed to be largely different in respect of religion. Moreover, it is also suggested that the Latins in Crete, who were mainly Venetians, are aggressive promoters of their faith by the references to their arguments used for proselytizing. Claims about any similar Cretan Byzantine attempt are absent in the letter, which allows for the impression that this community is less aggressive, implying a moral difference between the two subgroups. Such a presentation meets with the author's mindset, who was vehemently anti-Latin and did not fear to take a confrontative stance towards the Venetian authorities of Thessalonike when Byzantium seceded the city to the Serenissima in $1423 .{ }^{462}$

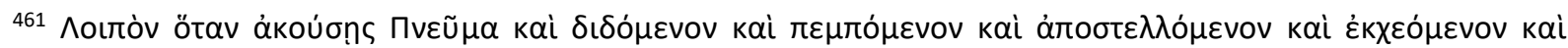

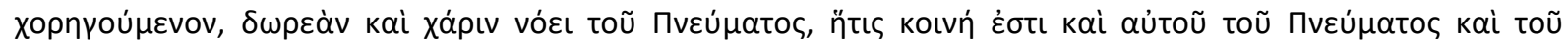

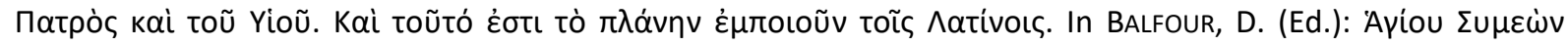

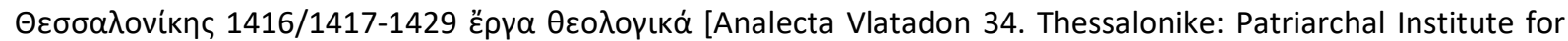
Patristic Studies, 1981]: 84-184, 199-246. p. 206. Henceforth BALFOUR 1981.

462 DeNNIS, George T.: The Late Byzantine Metropolitans of Thessalonike DOP 57 (2004), pp. 255-264, p. 261.
} 
Symeon of Thessalonike dismissed the Latins in a much shorter way in another letter, accusing them that they did not know anything about grace and believed that they [the Orthodox] regarded the Holy Spirit as personified. According to the archbishop, it is a pinnacle of blasphemy to say that they [the Orthodox] consider the uncreated and infinite nature to be personified and, because of this, [the Orthodox] speak foolishly about the incarnation of the Holy Spirit. ${ }^{463}$

These remarks portray the Latins as an arrogant and ignorant community. Symeon of Thessalonike claims that the Latins confuse the Orthodox teaching about the Holy Spirit being an uncreated and infinite divine nature with it being created, limited and substantiated. This leads them to accuse the Orthodox with teaching this non-existent tenet and with teaching the incarnation of the Holy Spirit as a consequence of their [of the Orthodox] false assumption. Supposedly, the Orthodox should not be understood as suffering from the same level of arrogance and ignorance at all. These circumstances imply considerable differences between the two denominations regarding haughtiness and knowledge, which also establishes solid boundaries between their respective Byzantine and Latin adherents in both fields.

Such accusations by Catholics, if they indeed existed, can be traced back to a misinterpretation of a Palamite teaching. A key Palamite idea is that divine life is

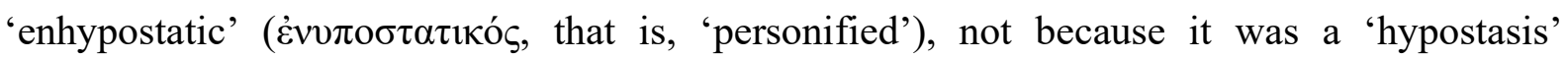

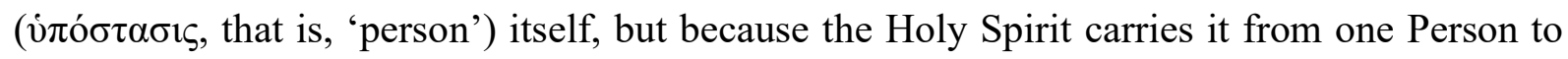
another. Barlaam Kalabros accused Palamism with seeing one more 'person' into God, the divine life carried by the Holy Spirit, which claim Gregorios Palamas fiercely rejected. ${ }^{464}$ The charge described by Symeon of Thessalonike seems to be a version of the accusation voiced by Barlaam, that is, a claim that Orthodox believers understand the Holy Spirit not as a

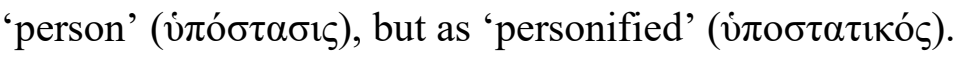

An even less tolerant commentary on the subject is preserved in the Epistula encyclica contra Graeco-Latinos et decretum synodi Florentinae of Markos Eugenikos. The author condemns the Unionists as half-animals, like the hippocentaurs of the myths, for they agree with the Latins that the Holy Spirit proceeds from the Son and it [the Son] is the cause of its

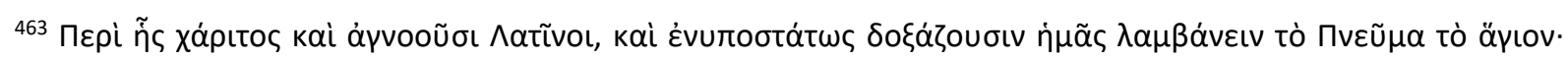

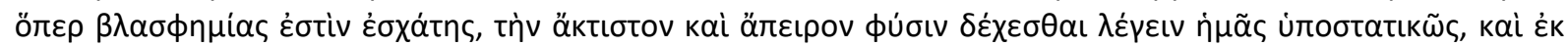

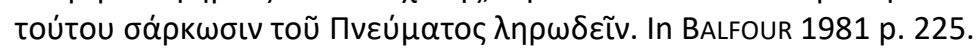

${ }^{464}$ MeYendoRfF 1979, pp. 32-33.
} 
[of the Holy Spirit] existence, and they agree with them [the Orthodox] that it [the Holy Spirit] proceeds from the Father. ${ }^{465}$

The presentation provided by Markos Eugenikos displays an evidently deliberate misinterpretation of the Catholic views on the origin of the Holy Spirit, as the Roman Church taught that the Holy Spirit proceeds from the Father and the Son, which was definitely known by metropolitan Eugenikos, who was one of the leading Orthodox theologians at the Council of Ferrara-Florence. His distortion represents the Filioque as a claim about the Holy Spirit proceeding (and, logically, being created) by the Son, a nonsensical and scandalous claim for any contemporary Orthodox believer. In turn, the Orthodox teaching is represented correctly and is clearly understood as 'right'. The difference between the two beliefs presented could hardly be any greater, which creates a strong religious boundary that separates the two denominations identified with these views. Logically, it affects both the Orthodox Byzantines and the Catholic Latins, suggesting a huge religious difference between the two communities, granting the higher status for the Byzantines.

However, the Unionist community seems to be his main target, as he strikingly dehumanizes them, portraying his opponents as 'half-animals' ( $\mu 1 \xi o ́ \theta \eta \rho \varepsilon \varsigma)$ and comparing them to the hippocentaurs or, shortly centaurs, the half-human, half-horse creatures of Ancient Greek mythology, depicting them as horrible monstrosities. The solutions of Eugenikos betray how much he was willing to distort facts and soar hatred in his audience to achieve his aim of disestablishing the Union. He also presented his strong tendency to use ad hominem arguments against his opponents once again. ${ }^{466}$

Writing to Demetrios Palaiologos, in 1449, Scholarios states that [the earlier mentioned many theologians of the Orthodox Church] the procession of the person of the Holy Spirit from the person of the Son, so that a person may proceed while caused to exist by another person, as if the causes (and, to avoid that the Latins may pretend if it was not so, that refers to the substances) of the Holy Spirit would differ only by existing by the Father himself or not by himself, ... that and all these dangerous and precipitous assumptions [those

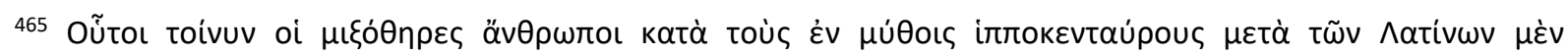

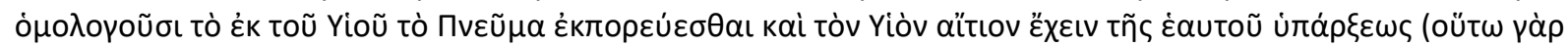

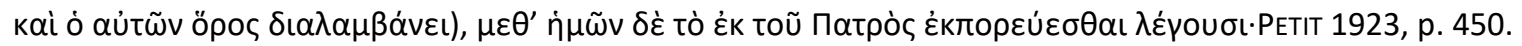
${ }^{466}$ GILL 1959, pp. 318-319.
} 
discussed earlier] they [the earlier mentioned Orthodox theologians] have led astray, drawing boundaries and warning those who dare to transgress. ${ }^{467}$

The letter attempted to achieve two goals. It aimed to prevent Demetrios Palaiologos from revolting against the accession of his brother, Konstantinos XI, like he earlier revolted against their late elder brother, Ioannes VIII, in 1442, while strengthening the bound between the addressee and the anti-Unionist camp. ${ }^{468}$ His claims, discussed above, are parts of his effort to achieve the latter goal, with the help of his theological and rhetorical knowledge. $\mathrm{He}$ relies upon the authority of several Orthodox theologians, including Photios and Theophylact of Ochrid, stating that they all refuted the Filioque, which he defines rather precisely, defining the limits of 'correct' views on the subject and warning the potential transgressors.

The Latins are involved in this argument only superficially; as Scholarios justifies his explanation of what he means by 'cause' ( $\alpha i \tau i \alpha$ ) with his attempt to avoid the Latins intentionally misinterpreting his words. The underlying theological conflict makes it clear that their supposed intent would be to explain away their theological 'errors'. Thus, the Catholic theologians are presented as unscrupulous debaters, who readily utilise theological spin to protect their allegedly false teachings according to Scholarios. That implies both a moral and a religious boundary between them and their Byzantine equivalents, who are supposed to have higher morals and 'right' religious views, for which Scholarios himself could be an example.

Writing to the mesazon Loukas Notaras, in 1452, Gennadios Scholarios attacks the Filioque in a less explicit way. As Scholarios claimed, [Notaras] said that the greatest emperor [Ioannes VIII] and the entire Senate almost rejected the Latin addition [the Filioque] with contempt, as their fathers regarded it [the Filioque] as abjured, what that nice oath of Florence ratified, and [their fathers] repeatedly stated that there could not be any Latinism ever, and they told the best and most sensible things. ${ }^{469}$

Scholarios opens his argument with stressing that it is a statement of Notaras that he paraphrases, which is a simple yet effective rhetorical device. Then, he swiftly continues with

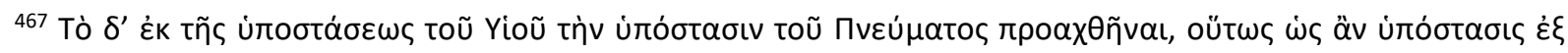

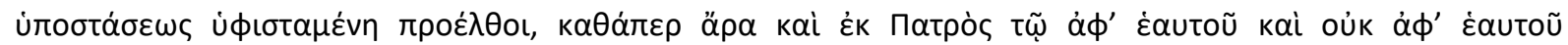

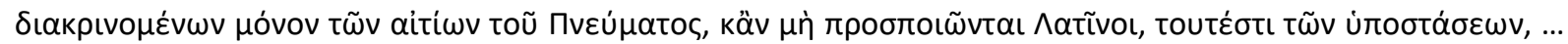

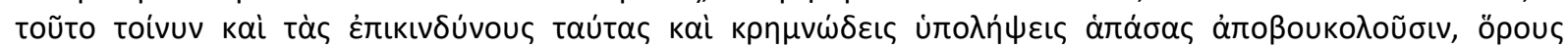

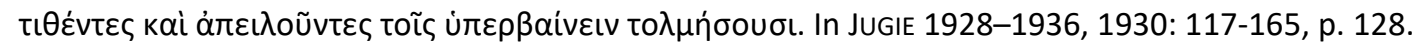

${ }^{468}$ BLANCHET 2008, pp. 219-223.

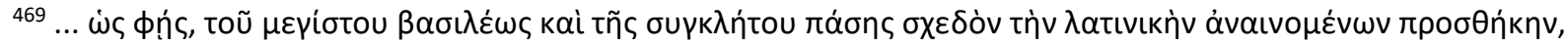

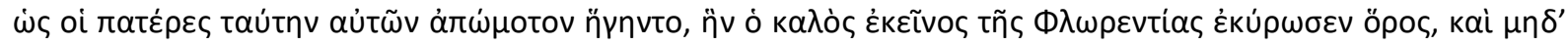

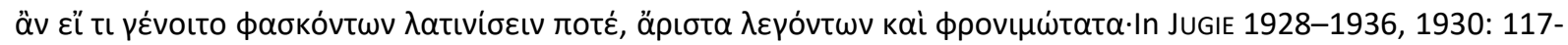
165, p. 148.
} 
a claim that Ioannes VIII and the entire Byzantine Senate almost rejected the Filioque, suggesting a strong opposition even among the highest political elite of the Empire. Scholarios explains it with the tradition of their forefathers, who declared the acceptance of the Filioque impossible on oath.

This statement is contrasted by the sarcastic claim about that 'nice' oath of Florence, which demanded the acceptance of the Filioque. At this point, the source suggests that the late emperor and the contemporary members of the Byzantine Senate violated the intellectual heritage of their ancestors, which swearing an oath about the exact opposite of what the previous Byzantine generations, presented as undivided in their views, believed. Their near rejection of the Filioque invokes an image of persons being aware of the meaning of what they are about to do and therefore being hesitant because of it.

Scholarios does not seem to be pleased with referring to the ancestors, thus, invoking their authority in contemporary Byzantine thinking, and their judgment over the Filioque. He goes further, stating that any adoption of Catholic beliefs was forbidden by the forefathers, and underlines that they told excellent and very sensible things.

This presentation aims to stress the excellence of the earlier Byzantine generations, and, through that, to boost their authority, and to claim that they rejected any adoption of Catholic beliefs, generalising their alleged opposition to Catholicism and suggesting a very negative image of the Latin Church. At the end of the argument, Ioannes VIII and his Senate are portrayed as persons who rejected a factually and morally right core belief of the faith of their forefathers, being aware and frightened of the meaning of their deed, therefore, committing a grave sin.

Such a condemning judgement on the previous emperor and his Senate was audacious and was made even more audacious by the facts that it was at least partly invented, and the addressee could be aware of this. Ioannes VIII was not hostile to the Filioque and, although nobody can reconstruct the views of each contemporary senator, many of them were surely not hesitant to accept the 'Latin addition'. ${ }^{470}$ Notaras, already a leading political figure in the time of the Council of Ferrara-Florence, was definitely aware of these circumstances, just like Scholarios, who was a leading member of the Byzantine delegation at the council.

Furthermore, Scholarios is silent about the fact that during the council he himself was very open to the option of Union, and argued that the 'addition of symbol', that is, the Filioque, although it was an unfortunate decision by the Latins, was only a minor historical

\footnotetext{
470 GILL, Joseph: John VIII Palaeologus. A Character Study. In GILL, Joseph: Personalities of the Council of Florence. Oxford, Basil Blackwell, 1964. pp. 104-124, pp. 122-123.
} 
difference between the Catholic and the Orthodox Churches. ${ }^{471} \mathrm{He}$ is similarly tacit about his own personal friendship with the late Ioannes VIII. ${ }^{472}$

This blatant falsification, presented to Notaras, who was aware of the facts, was firmly loyal to Ioannes VIII and Konstantinos XI, ${ }^{473}$ and wielded power over the author, could have serious consequences, if it were sent to him indeed. Nonetheless, Byzantine letter corpora were often edited by their authors to cosmeticize their own image for posterity, ${ }^{474}$ and Scholarios had little to fear about his claims being challenged as the first patriarch of Constantinople under Ottoman rule. Thus, it is a realistic possibility that the extant version of the letter differs from its original version, which was presumably more factual.

Analysing the representation of Westerners in the letter, it unfolds through the indirect comment of Scholarios on the Latin 'addition', that is, the Filioque. The context suggests it to be a terribly wrong religious belief, branding Catholicism itself in the process. The Westerners, followers of that faith, are logically burdened with being adherents of an utterly wrong faith. Meanwhile, the Orthodox viewpoint is tacitly but obviously understood as right, which elevates Orthodoxy itself and defines the Byzantines as adherents of the 'right' belief on the origin of the Holy Spirit. It all points to a great contrast between the two ethnic communities regarding religion, which favours the Byzantines.

\section{VIII.3. Support}

The addressee of a letter written by Demetrios Kydones is unknown, but it was sent to Thessalonike from the capital in 1384-1385, during the months of winter or spring. Kydones was highly critical of the decision of Manuel II Palaiologos of sending the Thessalonian hieromonk Euthymios, the later Patriarch of Constantinople, Euthymios II (1410-1416), ${ }^{475}$ as the leader of his embassy to Pope Urban VI (1378-1389), because Euthymios was staunchly anti-Latin in his views.

As he states, he is afraid that if [Eutyhmios] speaks a lot with those men [the Catholic negotiators], and fails with the refutation, he will suddenly realize that he himself worships

\footnotetext{
471 BLANCHET, Marie-Hélène: George-Gennadios Scholarios et la question de l'addition au symbole. In RIGo, Antonio - ERMILOV, Pavel (Eds.): Byzantine Theologians. The Systematization of Their Own Doctrine and Their Perception of Foreign Doctrines. Università degli Studi di Roma "Tor Vergata”, 2009. Pp. 181-192, p. 186.

${ }^{472}$ GILL, Joseph: George Scholarius. In GILL, Joseph: Personalities of the Council of Florence. Oxford, Basil Blackwell, 1964, pp. 79-94, p. 81.

473 MATSCHKE 1992, pp. 66-67.

${ }^{474}$ HATLIE, Peter: Life and Artistry in the 'Publication' of Demetrios Kydones' Letter Collection. GRBS 37 (1996), No. 1, pp. 75-102, pp. 78-79.

475 PLP 6268.
} 
the Son like he does the Father, and agrees that the Holy Spirit is their common creation, and will return to them [to the Byzantines] addressing many encomia of those who think that way. $^{476}$

The words of Kydones are filled with evident irony, as he envisages the possible conversion of Euthymios to the Catholic understanding of the Holy Trinity through frequent conversations with Catholic theologians, and his astonishing return to the Byzantine Empire as a eulogist of such views. Regarding the background of the ambassador, such an outcome was hardly probable, and the sarcasm in the lines of Kydones underlines this problem.

It is worth remarking, however, that, in spite of being an adherent of Palamism, Euthymios was also a good friend of Kydones. ${ }^{477}$ Furthermore, because of the highly public nature of Byzantine epistolography, and the fact that both Euthymios and the unknown addressee belonged to the higher echelons of Thessalonike, it would have been very difficult to assure the secrecy of the joke made by Kydones. These details suggest that Kydones was not concerned with Euthymios taking his wit as an insult.

Even if it is wrapped in irony, the text implies a positive view on the Filioque, and, through that, about Catholicism, while the positive image of their faith also enhances the standing of the Latins in respect of religion. In turn, the Byzantine view on the procession of the Holy Spirit is tacitly invalidated, weakening the position of Orthodoxy and its Byzantine believers. The existence of a religious boundary between the Byzantines and the Latins is not questioned, but the evaluations of its two sides are challenged, just like the degree of difference in this respect. Such a portrayal fits well into the generally pro-Latin worldview of Demetrios Kydones.

Kydones is not the only author in the analysis, who serves with supportive presentations of the Filioque. In a letter, written to Manuel Raoul, sent to Cyprus, from Italy, Manuel Kalekas sadly states that one should add to those [to the aforementioned negativities] the evil ones of the people, who command that those who worship the Son like the Father should not even be considered Christians. ${ }^{478}$

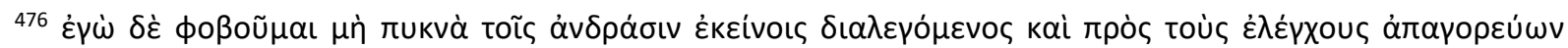

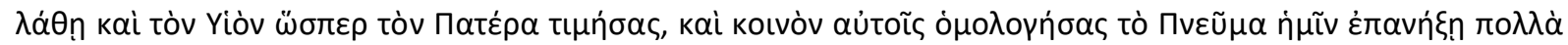

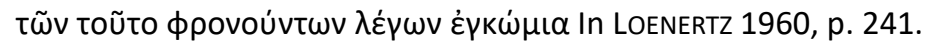

477 DenNIS, George T.: The Reign of Manuel II Palaeologus in Thessalonike, 1382-1387. Rome, Pontificale Institutum Orientalium Studiorum, 1960, p. 137.

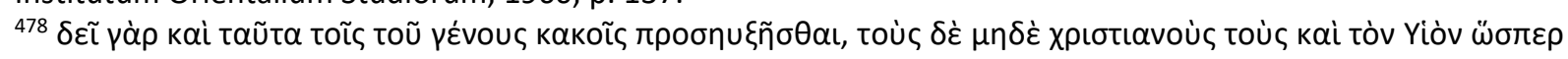

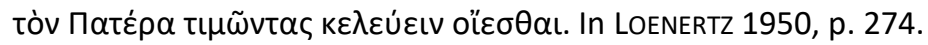


This is evidently a reference to the Filioque and the popular resentment of Catholics in contemporary Byzantine society in Cyprus for their belief in this doctrine. Claiming that those who condemn Catholics for the Filioque order that an Orthodox believer should not regard them even as fellow Christians, Kalekas identifies the Byzantine Cypriot opponents of the Filioque with an extreme point of view among their ranks, thus creating a strawman argument.

That distorted image of the Orthodox critics of the Filioque also establishes a firm ground to identify them with 'the evil ones of the people' ( harsh moral judgement on them, portraying their group as persons of vile intents. Catholics, however, are only featured as mere victims of these attitudes that facilitates imagining them as more moral persons, not fuelled by a similar hatred.

The extent of the religious difference is also questioned by the suggestion that the Orthodox should accept the Catholics as fellow Christians, limiting the importance of the question. As a result, Cypriot Byzantines and Westerners, the two communities identifiable in the conflict presented by Kalekas, are featured as separated by boundaries in respect of religion and morality, but, while the importance of the religious difference is questioned, the moral difference seems to favour the Latins.

The main problem with such an argument, besides its distortion of the two groups involved, is that the Orthodoxy of any claim about equal worship of the Father and the Son was easily questionable relying on a quote attributed to Christ in the Gospel of John: 'My Father is greater than I., ${ }^{479}$

In a letter, addressed to Pope Nicholas V (1447-1455), Ioannes Argyropoulos claims that it is impossible for the Holy Spirit to come from the Father, unless it comes through the Son, as the teachers of the Latins and the Greeks teach it. ${ }^{480}$

There was a certain theological basis to make such a statement by a fifteenth-century Byzantine and a reason to do so. Many Greek Fathers, including the Cappadocians and the

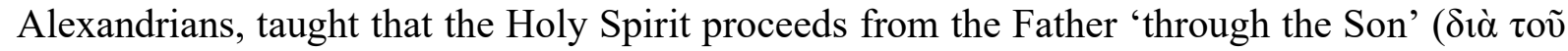

\footnotetext{
479 Jn 14,28.

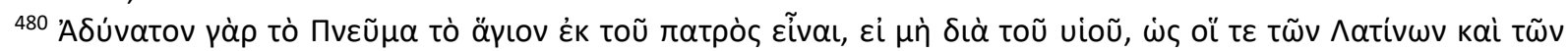

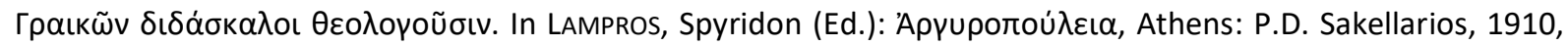
pp. 129-141, p. 137.
} 
Yioṽ), and the Latin 'from the Father and the Son' (ex patre et filioque) was commonly interpreted by pro-Latin Orthodox scholars as being an inapt formulation of this doctrine. ${ }^{481}$

Therefore, the statement made by Argyropoulos was in accord with the official Unionist view, which was hoped to provide a common denominator for moderate Catholics and moderate Orthodox, and to lead to the solution of the Filioque-debate, but in vain. Pope Nicholas V was a former participant of the Council of Ferrara-Florence, and a notable connoisseur and patron of Greek culture, ${ }^{482}$ a person who definitely fit into the former category.

The two communities presented by Argyropoulos are the Catholic and Orthodox religious authorities, who appear in perfect accordance with regard to the procession of the Holy Spirit. Other theological questions are not addressed, but the fact that the contradicting views on the origin of the Holy Spirit, traditionally regarded as the most important dogmatic difference between the two denominations, is presented as non-existent, greatly limits the possible extent of religious difference between the two faiths. As a result, the religious boundary between the Byzantines and the Latins is relativized, suggesting a much lesser degree of difference than it was traditionally understood by the Byzantines.

\section{VIII.4. Conclusion}

In the analysed letters, the three main attitudes toward the subject of the Filioque are denial, condemnation and support. The absolute majority of the references in these sources represent a strict rejection of the Latin view on the procession of the Holy Spirit, standing in accordance with the importance of this dogma for the anti-Latin camp in the justification of their theological opposition to Roman Catholicism.

As the actual Catholic teaching met with such a fierce condemnation, it is understandable that even its outright denial appears in references left behind by more-openminded debaters, even if it had very limited chances to placate the anti-Latin Orthodox theologians, like, for instance, Gregorios Palamas himself, because many of them were aware of the core Catholic teachings.

\footnotetext{
${ }^{481}$ Stavrou, Michel: The Divine Unity and the Relationship among the Persons of the Trinity in Orthodox Theological Tradition. In BöHNKE, Michael - KATTAN, Assaad Elias - OBERdORFER, Bernd (Edd.): Die FilioqueKontroverse: historische, ökumenische und dogmatische Perspektiven 1200 Jahre nach der Aachener Synode. Freiburg - Basel - Wien, Herder, 2011, pp. 298-311.

482 HeRRIN, Judith - MCMANUS, Stuart M.: Renaissance Encounters: Byzantium Meets the West at the Council of Ferrara-Florence in 1438-1439. In BROWNLEE, Marina S. - GoNDICAS, Dimitri H. (Eds.): Renaissance Encounters: Greek East and Latin West. Leiden, Brill, 2013, pp. 35-56, p. 55.
} 
Finally, as it proved necessary, even pro-Latin theologians addressed the Filioque in its actual meaning, and sometimes did it rather creatively, as the Roman Catholic Demetrios Kydones did, who ironically voiced his 'fears' that his hesychast friend, Euthymios may actually accept that the Holy Spirit proceeds from the Father and the Son. 


\section{Common Beliefs?}

Besides the subjects regularly debated in Byzantine arguments about Catholicism that are also present in the analysed letters, there are also epistles promoting the existence of a 'general religious common ground' between the two denominations. These pro-Latin presentations offer interesting insight into the world of Byzantine debates regarding Catholicism and its predominantly Latin adherents.

\section{IX.1. Remaining Open to Each Other}

An implicit praise of such an open-minded attitude towards the Latins appears in one of the numerous letters of Demetrios Kydones (1324-1398), which was written to Georgios, called the philosopher, who can be identified with Georgios Kydones Gabrielopoulos. ${ }^{483}$ The letter, sent to Cyprus from Constantinople in 1362, reflects on the views exposed by Georgios. As Kydones states, as certain people praised the difficult situation [of Gabrielopoulos] regarding the legate and cheered when he [Gabrielopoulos] was beaten and imprisoned, and alleged as a cause [of it] from outside that [Gabrielopoulos] did not prove clearly that the Latins are heretics, but spared the men [the anti-Latins], repeatedly claiming that they [the Latins] are theologising in an obscure way and so he [Gabrielopoulos] seemed to give them [the Latins] ground. ${ }^{484}$

Gabrielopoulos was an anti-Palamite, who originally supported the Union of the Churches. However, he had an angry debate with the papal legate Pierre de Thomas, the later Latin Patriarch of Constantinople (1364-1366) ${ }^{485}$ in Cyprus (1361), was physically insulted and incarcerated, ${ }^{486}$ and was even threatened with being burned alive at the stake. ${ }^{487}$ The intended encouragement by Kydones, namely that Gabrielopoulos should not fear the fire of

\footnotetext{
483 PLP 3433.

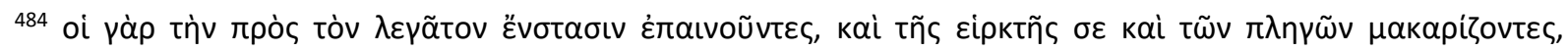

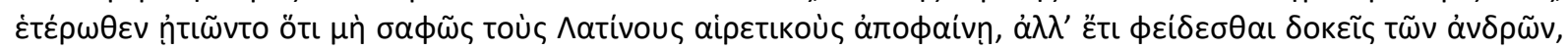

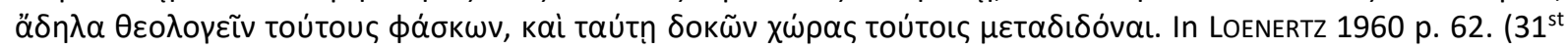
letter)

485 PLP 7799.

486 TINNEFELD Franz: Georgios Philosophos. Ein Korrespondent und Freund des Demetrios Kydones. OCP 28 (1972), pp. 141-171, p. 152. Henceforth TINNEFELD 1972.

487 WEISS, Günter: Joannes Kantakuzenos - Aristokrat, Staatsmann, Kaiser und Mönch - in der Gesellschaftsentwicklung von Byzanz im 14. Jahrhundert (Schriften zur Geistesgeschichte des östlichen Europas 4.) Harrassowitz, Wiesbaden, 1969, p. 64.
} 
the pyre, ${ }^{488}$ had a doubtful potential to change the mind of the prisoner, whose attitudes should be assessed in the light of the fact that, in his previous letter to Kydones, he had charged Pierre de Thomas even with pederasty. ${ }^{489}$ After the incident, Gabrielopoulos kept his intellectual distance of both Palamist and Unionist views. ${ }^{490}$

Nevertheless, the lines of Kydones portray an interesting image of Catholics through the ideas attributed to Gabrielopoulos. They are depicted as a group who are definitely not heretics but are merely criticised for theologising in an obscure way, implying that they are faithful Christians who simply fail to adequately express their beliefs. In turn, the status of Orthodox believers as faithful Christians is not challenged, allowing the audience to regard them as such. All of this gives the impression that Catholics and Orthodox Christians are not very distant from each other regarding religion and allows to question the existence of any boundary between them, which stands for the Latins and the Byzantines who belong to these two denominations.

However, if differences are minor or even non-existent, then what is the reason behind the continuing separation. The answer is suggested to be the intolerant prejudice present in both sides. The papal legate ordered the beating and imprisonment of Gabrielopoulos for mentioning that Catholic theology proves to be obscure in certain points, and Orthodox antiLatins cheered at his sufferings, portraying it as deserved for not calling the Latins heretics. Both communities are presented as plagued by intolerant people within them, who want to see the other denomination as wrong and their own faith as perfect, which positions the two groups also rather close to each other regarding their morals, as both are troubled by similar shortcomings displayed by many of their members.

Another letter of Kydones, sent to Ioannes Kyparissiotes in Cyprus, written in Constantinople, on the summer of 1371, goes further in promoting an open-minded attitude. The author tries to console his friend, because, as he puts it, he [Kyparissiotes] will seem to the abominable ones [the Hesychasts] as somebody who deserves the punishments of blasphemy. ${ }^{491}$ As he states, Italy is a nice place and it can be of much avail for those who dwell there, especially as it offers to bring them together with influential and righteous men. However, one who wants to enjoy the good things provided by them [by the Italian elite] must

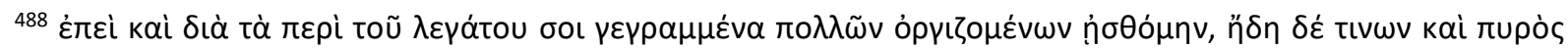

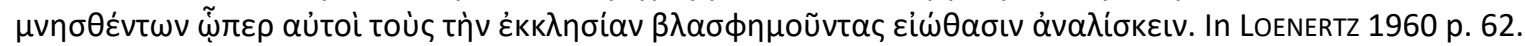

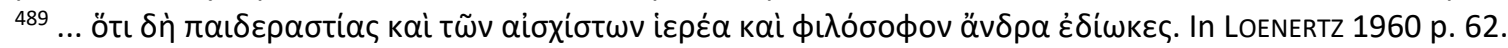


command their language, as the unintelligible speech or the deduction of their [of the Italian elite] thoughts from nods differs in what from communing with the herds of oxen or donkeys? $?^{492}$

Ioannes Kyparissiotes was staunchly anti-Palamite and one of his most important works is his tractate against Hesychasm, the П $\alpha \lambda \alpha \mu \imath \tau 1 \kappa \alpha i ̀ ~ \pi \alpha \rho \alpha ́ \beta \alpha \sigma \varepsilon 1 \zeta$, in which he particularly dealt with the Palamite teachings of Neilos Kabasilas, aiming to discredit them with the device of theological speculation. ${ }^{493}$ After the triumph of Hesychasm in the Church of Constantinople, his position proved untenable in Byzantine domains, so he emigrated, as it appears in the letter of Kydones too.

The letter reached Kyparissiotes in Cyprus, but he later made his way to Western Europe, and even lived in the court of Pope Gregory XI (1370-1378), from November 1376 to December $1377 .{ }^{494}$ In the papal court, he enjoyed a remarkable level of respect, earning

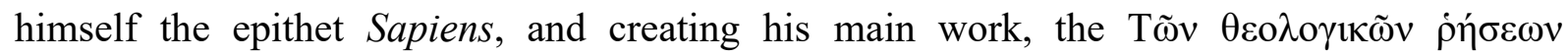
$\sigma \tau o \imath \chi \varepsilon ı \omega ́ \delta \eta \varsigma ~ \varepsilon ै \chi \theta \varepsilon \sigma \iota \varsigma$, which made him probably the first Byzantine theologian to realise a work through the methods of Western Scholastics. ${ }^{495}$

The statement of Kydones about the Hesychasts thinking that Kyparissiotes would deserve punishment for blasphemy definitely refers to the religious conflict that led to the emigration of Kyparissiotes. Moreover, Kydones makes it clear that he agrees with his friend and condemns the Hesychasts, as he calls the members of the latter group 'abominable ones'

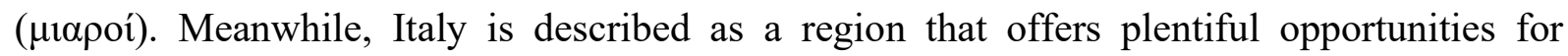
educated persons, implicitly arguing that being Greek is not a problem.

The sources of these opportunities are claimed to be the educated members of Italian high society, who appear as open to the cultural goods a person like Kyparissiotes can offer to them. He merely has to learn their language, which is presented as the sole important boundary between the Greek scholar and his hopeful patrons, devaluing the role of ethnic background and religion as boundaries and underlining the importance of a common language and a shared interest in culture.

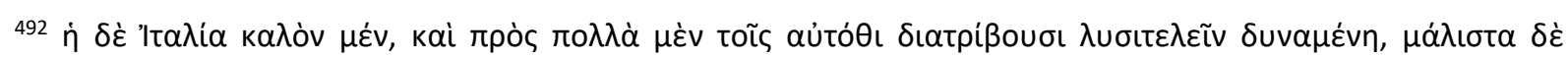

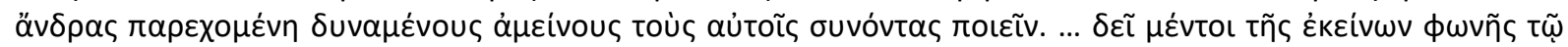

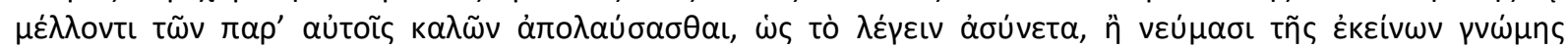

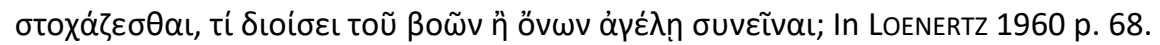

493 BECK, Hans-Georg: Kirche und theologische Literatur im byzantinischen Reich. C. H. Beck'sche Verlagsbuchhandlung, München, 1959, p. 739.

494 On this period of his life, see MERCATI, Angelo: Giovanni Ciparissiota alla corte di Gregorio XI (Novembre 1376-Dicembre 1377) BZ 30 (1929), pp. 496-501.

495 GeANAKOPLOS, Deno John: Western Influences on Byzantium in Theology and Classical Latin Literature. In GEANAKOPLOS, Deno John: Interaction of the 'Sibling' Byzantine and Western Cultures in the Middle Ages and Italian Renaissance (330-1600), Yale University Press, New Haven and London, 1976, pp. 103-104.
} 
In comparison, the circumstance that the enemies of Kyparissiotes had the power to force him into emigration implies that this fanatic attitude is at least strongly present among powerful Byzantines. This religious bigotry, combined with the absence of any mention to the appreciation of culture among the higher echelons of Byzantine society and the praise of the interest in culture shown by their Italian counterparts also give the impression of erudition being less important for influential Byzantines. As a result, the respective elites of Byzantium and Italy appear as considerably different in regard of both religious tolerance and the appreciation of culture, favouring the Italian side in both respects.

\section{IX.2. Sympathy towards Catholicism}

Nevertheless, there are texts among the analysed sources that present even more acceptant attitudes towards Western religious views. A letter of Kydones was sent to the bishop Symon Atoumanos, probably to Cassano in Calabria, from Constantinople in the summer of 1364. Kydones congratulates to the Greek Symon for becoming the Catholic bishop of Cassano, stating that it is a common panegyric for him [Kydones] how the community of the [Catholic] Church has judged about him [Atoumanos], not only because of the proverb that the successes of friends are shared with their friends, but because his [of Atoumanos] wreaths represent the community of the Hellenes more gloriously than the virtues of those men of ancient times and the ones [virtues] that among the people now being among them [among the Byzantines] may see the Romans. ${ }^{496}$

Atoumanos had already achieved a high rank in the Catholic Church at the time when Kydones wrote his letter to him. Immigrating to Italy from Byzantium, he was consecrated as the Bishop of Gerace, as the successor of Barlaam Kalabros on June 23, 1348 and had held the position until 1363, when he was named bishop of Cassano. ${ }^{497} \mathrm{He}$ had served the Catholic Church in this position until April 17, 1366, when he became archbishop of Thebes in Central Greece, ${ }^{498}$ possibly ending his tenure with his death in 1381.499

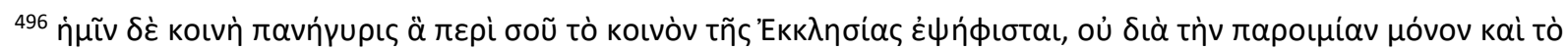

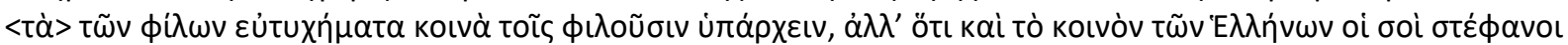

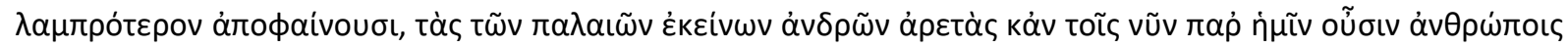

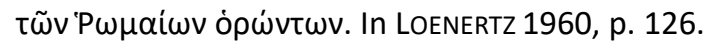

497 PLP 1648.

498 SETTON, Kenneth M.: The Byzantine Background to the Italian Renaissance. Proceedings of the American Philosophical Society, Vol. 100, No. 1 (Feb. 24, 1956), pp. 1-76, p. 47.

${ }^{499}$ SETTON, Kenneth M.: Catalan Domination of Athens, 1311-1388. Variorum, London, 1975, p. 143.
} 
The words of Kydones arrived in Atoumanos in 1364, the year after the latter had received his new position as bishop of Cassano, and the superlatives of Kydones do not only represent his close friendship with Atoumanos and the stylistic norms of Byzantine literature, but also his own religious views. As a Catholic, Kydones doubtlessly regarded the consecration of his friend as bishop of Cassano as a great achievement, especially praiseworthy because Atoumanos had not only become a Catholic bishop of Gerace in 1348 but was promoted to the see of Cassano in 1363, despite being a Byzantine immigrant to Italy.

The image of the Catholic high clergy in Italy and the unfolding of the letter also prove to very positive. Albeit they are only mentioned as those who judged the friend of Kydones worthy for his important new position, the praise of Atoumanos adds further elements to their portrayal. They are suggested to be people who understood the personal qualities of the Byzantine immigrant and selected him for them, not influenced by prejudices against his ethnic background and his Orthodox past. It gives the impression that they are wise and benevolent persons.

The Orthodox high clergy is not mentioned at all, but the main concern of the letter is the request from Kydones to Atoumanos to lobby for Catholic help to save Orthodox Byzantium against the Ottoman Empire. It allows the audience to regard them as also respectable. This interpretation would imply that differences between the high clergies of the two churches with respect to wisdom and benevolence are minor at worst, offering an opportunity for a compromise.

A markedly different type of openness unfolds in another letter of Kydones, sent to his mentor, Neilos Kabasilas to Constantinople, from the city itself, shortly before 1356. In that source, Kydones wrote that he would like if he [Kabasilas] would pause with the service of the emperor for a little while, and would take a look upon those things about which they [the Byzantines] and the Latins happen to disagree for such a long time, and [to the fact that] why could someone, talking about the love of strife dividing the entire world, not seem to be ridiculous, struggling with men who have been artists of speech for a long time. ${ }^{500}$

This letter of Kydones was written after he had completed his first major work as a translator of Latin theology. Kydones learned Latin for the sake of not being dependent on translators during his discussions with Western diplomats. He learned the language from the

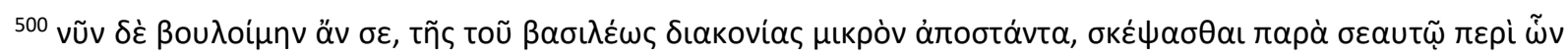

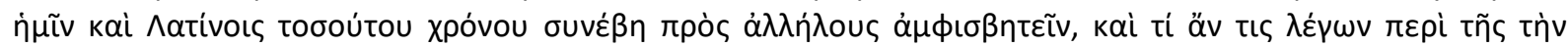

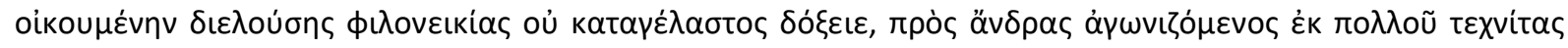
toũ $\lambda \varepsilon \dot{\gamma} \varepsilon$ IV. In LOENERTZ 1960, p. 327.
} 
Dominicans of Pera and soon started to translate the Summa contra gentiles of Thomas Aquinas. Ioannes VI Kantakouzenos (1347-1354) saw it as a useful demonstration of willingness to reunite with Rome, so he supported him and, by 1354, the translation was ready.

Kydones thereafter intended to refute the statements in the work that contradicted Orthodox teachings, but he was unable to do so, just like the tractates he consulted. Therefore, he turned to Neilos, who could not give any other advice, but to follow his own conscience and not to care about either the authorities, or his fellow citizens. ${ }^{501}$ It seems that Kydones made his decision rather soon after receiving the answer of Kabasilas. Franz Tinnefeld dates his conversion to Catholicism to 1356 , one year before he became a Catholic priest. ${ }^{502}$

The letter in question is the one mentioned above, in which Kydones asks for advice from Kabasilas in his crisis of faith, and his portrayal of the Catholic-Orthodox conflict proves intriguing. The conflict of the two denominations is presented without attributing responsibility to any of the two parties, probably mirroring the uncertainty of Kydones about the theological conflict. Moreover, the schism is only featured through one of its aspects, namely its grave nature, deconcretising the subject further.

In this context, the religious difference between the Catholics and the Orthodox is presented as given, but without positive-negative evaluations, without a clear extent and without evident responsibilities for the conflict resulting of it, suggesting them to be groups similar to each other, troubled by an escalated controversy. The two denominations logically included most Westerners and most Byzantines, respectively, so the very same stands for these two communities.

\section{IX.3. The Hope of Christian Solidarity}

A peculiar version of the representation of Orthodoxy and Catholicism as being close to each other in the analysed sources is the hope of Christian solidarity in the face of the Ottoman threat. In a letter of him, written to bishop Symon Atoumanos in the summer of 1364, Demetrios Kydones ponders on the possibilities of Western aid. As Kydones states, according to him, with the words of Demosthenes, it is likely and will be likely in the future

\footnotetext{
${ }^{501}$ CongourdeaU, Marie-Hélène: Nicolas Cabasilas et la théologie latine. In RIGO, Antonio - ERMILov, Pavel (Edd.): Byzantine Theologians. The Systematization of Their Own Doctrine and Their Perception of Foreign Doctrines. Università degli Studi di Roma "Tor Vergata", 2009, pp. 169-179, pp. 170-171.

502 TINNEFELD 2010, pp. 7-8.
} 
too, by the Franks to restrict their good deeds to mere speech, letters and promises. The Turks are already asking it with laughter if somebody has heard about the Crusade?

Therefore, he [Kydones], although he spoke a lot with and gave a lot of pieces of advice to the embassy [to the West], could not convince it to leave [to the West]. All the shouting is in vain if somebody seeks to destroy and bind the powerless ones, and it is easier to expect that the Antipodes will arrive and join [the Byzantines] as allies, than that the Franks will do the same. ${ }^{503}$

It is important to keep in mind for the interpretation of the letter that Atoumanos visited Constantinople in the previous year and advised Ioannes V Palaiologos (1341-1376; 1379-1390; 1390-1391) to send embassies to the West and plead for help against the Ottomans, which could seem rather futile for the Byzantine court in the mirror of the earlier promises of military aid made by the papal legates Peter of Smyrna and Pierre de Thomas, which had remained unfulfilled. ${ }^{504}$

The entire analysed section is characterised emotionally by a strong sense of melancholy and tangible irony. Kydones portrays himself as a person who has already lost almost all hope in the arrival of Western military aid, and sarcastically laments on the situation that he describes. The allusion to Demosthenes is used to underline the impression of the author that the current political situation will continue until the, regarding the military developments, most probable, fall of the Byzantine Empire.

It is an implicitly presented vision of the future that appears in the letter all the more predictable as the Ottomans are portrayed as perfectly aware of the Western attitudes, emboldened by them so much that they comment on the prospect of a Crusade as being a farce. Their alleged malignant humour is contrasted by the desperate irony displayed by Kydones himself, whose supposable motivations for this are anger and a certain sad acquiescence.

The author depicts the chances of an army of Antipodes, the supposed inhabitants of the 'inferior hemisphere' of the Earth in Ancient Greek and Roman culture, in Byzantine

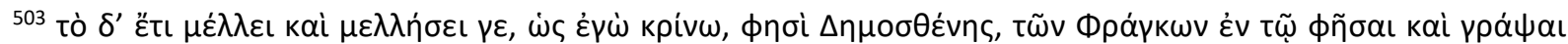

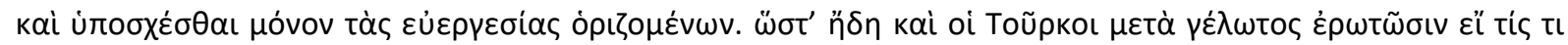

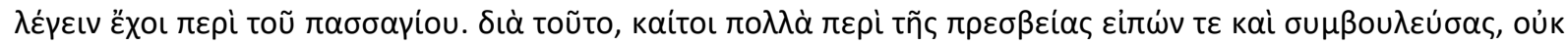

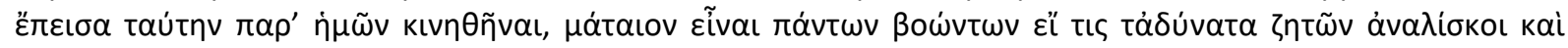

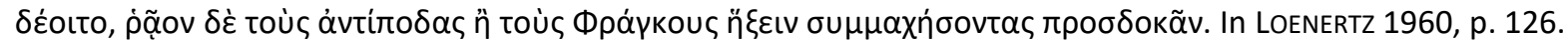
504 KIANKA, Frances: Byzantine-Papal Diplomacy: The Role of Demetrius Cydones. The International History Review, Vol. 7, No. 2 (May 1985), pp. 175-213, pp. 190-191.
} 
times usually regarded as non-existent, ${ }^{505}$ to arrive and assist the Romans as being higher, than the chances of an army of Latins doing the same. The reason of this tragic lack of aid is explained by the perceived dominance of a ruthless Realpolitik, which does not care with complaints and pleas for help if they come from powerless communities.

This is an important factor to evaluate the image of the Franks in these lines of Kydones. They are criticised for offering empty promises instead of any real help, and even the mere possibility of them sending an army to assist the collapsing Byzantine Empire against the Ottomans is in doubt. However, it is not presented as a peculiar characteristic of the Franks, but as a general human behaviour to leave those who are powerless to their fate when they are abused. As the hypocritical behaviour of the Franks is claimed to be common with all ethnic groups, it cannot create any boundary between them and the Byzantines.

Disappointing commentaries on the subject are not limited to the previous letter of Kydones. Writing to his brother, Prochoros, from Rome, during 1369-1370, the mesazon discloses his own, disappointing personal experience regarding Christian solidarity. At that time, Demetrios Kydones was a member of the diplomatic contingent of Emperor Ioannes V Palaiologos, who personally led the mission attempting to achieve Church Union and secure Western military assistance against the Ottomans. ${ }^{506}$

As Kydones explains, the Romans [the members of the papal court] explain their [of the Byzantines] ill [fortunes] with their religious beliefs and their innovation in Church and piety, and call the hybris of these barbarians [of the Ottomans] a [divine] punishment. ${ }^{507}$ This caption of the letter presents the audience with a not-too-understanding Catholic interpretation of the decline of Byzantine power and the Ottoman conquests. The view of the papal court on these, from the Byzantine view, most unfortunate political developments is claimed to be that they are divine retribution against the Byzantines for their very vaguely described religious errors.

A certain degree of pity may be supposed behind these Latin claims, but Kydones does not attribute any such emotion to the Catholic side and their alleged interpretation of Ottoman advances as the consequences of Byzantine religious errors suggests against this attribution.

\footnotetext{
505 DöRRIE, Heinrich: Antipodes. In CANCIK, Hubert-SCHNEIDER, Helmuth (Edd.): Der Neue Pauly. Enzyklopädie der Antike. Band 1. Metzler, Stuttgart-Weimar, 1996, p. 788.

${ }^{506}$ KIANKA, Frances: Demetrius Cydones: Intellectual and Diplomatic Relations between Byzantium and the West in the Fourteenth Century. New York, Fordham University, 1981. p. 174.

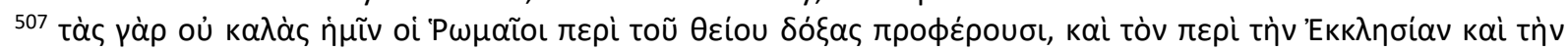

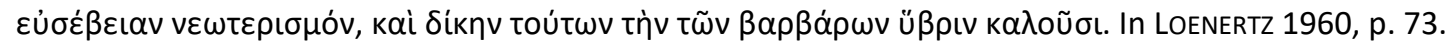


The Catholic negotiators are presented as being judgmental towards Byzantium and having little sympathy towards it, which attitudes rely on the contempt they feel for the Orthodox faith of the Byzantines. All of that is clearly unfair in the eyes of Kydones, especially as the imperial embassy has come to negotiate about Church Union with the papal court. The contrast between the two groups of negotiators with regard to Christian solidarity is sharp and this huge difference favours the Byzantines.

It is also remarkable that Kydones designates the Catholic negotiators with the ethnonym 'Roman', which the Byzantines usually used for themselves. The explanation for this peculiar phenomenon lies within the views promoted by Kydones. He argued that the Italians were in fact still 'Romans' and, as Rome was the metropolis of Constantinople, a special relationship existed between Byzantines and Italians. ${ }^{508}$

Demetrios Kydones was not alone with such great expectations about Western aid for Byzantium. Manuel Kalekas, writing to Maximos Chrysoberges, who resided in Italy, in September-October 1396, confesses that this fame of those men [of the soldiers of the Crusade of 1396] provided hope, which great ones he [Chrysoberges] said that he had seen in Italy, filled with zeal because of their [of the Byzantines] sufferings, and the crowd of military contingents [provided hope too], and this expedition has been hoped for a long time and which alone seemed sufficient to achieve their [of the Byzantines] freedom instead of the previous slavery, with the help of God. ${ }^{509}$

Kalekas refers here to the gathering of the forces of the Crusade of Nikopolis in the first half of 1396, culminating in the creation of a formidable army of various Western nations under the command of King Sigismund of Hungary (1387-1437). The establishment of such an army against the Ottoman Empire rightfully raised hope in many Byzantines, detectable in the letter of Kalekas too. However, the army suffered a crushing defeat from the Ottoman forces at Nikopolis ${ }^{510}$ (nowadays Nikopol in Northern Bulgaria) on 25 September 1396, shattering Byzantine hopes. ${ }^{511}$

The letter grips the atmosphere of the expectations of those Byzantines, who hoped that the Crusade may deliver them from the Turkish threat and would provide better

\footnotetext{
508 RYDER 2010, pp. 71-72.

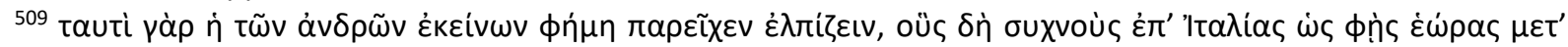

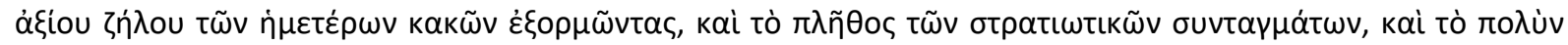

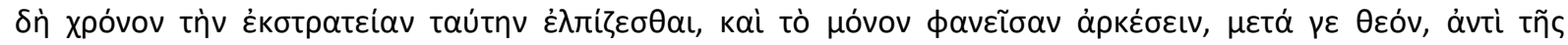

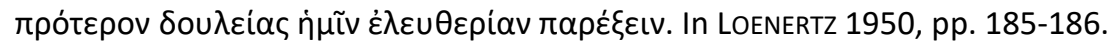

510 Nowadays Nikopol in Bulgaria.

${ }^{511}$ See, for instance, BARKER 1969, pp. 133-139 on the Battle of Nikopolis and the Byzantine reactions to it.
} 
opportunities for their state in the future. The soldiers of the Latin army are portrayed as brave warriors who feel sympathy for the sufferings of the Byzantines and are ready to endanger even their very lives in an attempt to help them and restore their freedom, ending their oppressed situation. Their solidarity towards the Byzantines is requited by the solidarity for them by the pro-Latin Byzantines, portraying the members of the two groups as similar in this respect, and implying that they do not differ from each other considerably in general. And such a depiction suggests that other Latins and Byzantines could be rather similar to each other in comparison.

The hope of Western solidarity is presented in a more optimistic tone in a letter of Manuel II Palaiologos. The letter was addressed to Euthymios, the later patriarch of Constantinople (1410-1416), sent to the imperial capital, from Paris, during the springsummer of 1401. The main concern expressed in the source is the seemingly successful attempt of the emperor to secure military aid against the Ottoman expansion. As he states, there is need of nothing else but the arrival of the day of starting the [of the emperor himself] journey to him [Euthymios] - as a day must be designated, just like a place where the contingents of the Britons and the other allies could assemble - so he [the emperor himself] started to write immediately. ${ }^{512}$

The most important detail is the awaited coming of Briton, that is, English, and other allied troops, logically Westerners, once again after the catastrophe at Nikopolis. As Manuel II had been negotiating with Western European rulers personally, including Henry IV of England (1399-1413), receiving very favourable promises in exchange of being open to the Church Union, the new crusading army was supposed to be more numerous and better organised than the previous one, defeated in 1396 by the Ottomans. ${ }^{513}$

Mainly this factor should be credited for the optimistic tone of the letter, but it was probably not the only one. Euthymios, although being a friend of the emperor, is remembered as a strong supporter of Palamism and an active anti-Latin polemist. ${ }^{514}$ The promised arrival of Western military aid was definitely beneficial for the Byzantine state, but it came with a

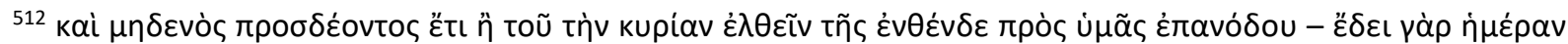

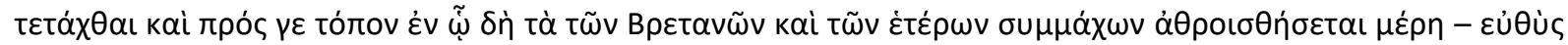

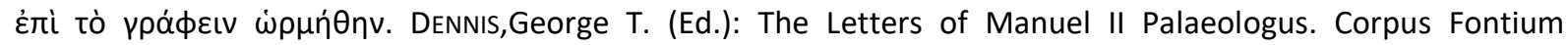
Historiae Byzantinae. Series Washingtonensis 8. Washington, D.C.: Dumbarton Oaks, 1977, pp. $105-107$. 513 BARKER 1969, pp. 181-184.

514 DeNNIS, George T. (Ed.): The Letters of Manuel II Palaeologus. Corpus Fontium Historiae Byzantinae. Series Washingtonensis 8. Washington, D.C.: Dumbarton Oaks, 1977, pp. xl-xli.
} 
possibility of establishing Church Union on Catholic terms, which was regarded as a grave danger by anti-Latins, including Euthymios himself.

Therefore, it was very logical for Manuel II to present the prospect of Western aid most positively, completely omitting any references to the possible unification of the Catholic and Orthodox Churches. It had the potential of easing the fears among the anti-Unionist members of a Byzantine audience about the possible religious consequences of his quid pro quo negotiations, while strengthening their hopes about the future of the Empire, and possibly making them less hostile towards Westerners.

The Britons and other Catholic Westerners are presented as willing to wage war to assist the Byzantines, logically to be explained with their fervent Christian solidarity towards them. Albeit the Byzantine attitude is not discussed by the author, his positive attitude towards the allied troops implies the existence of Orthodox Byzantines who feel similarly for the Latins. Their shared Christian solidarity towards the other ethnic community invokes the impression that these two subgroups are relatively similar to each other in general, which points to a considerable similarity between the Byzantines and the Latins in general. It is only enhanced by the circumstance that solidarity on both sides is logically felt towards the entire other community, not only towards those who are positively disposed towards the other group.

\section{IX.4. Conclusion}

The subjects addressed by the letters analysed in this chapter can be organised into three major groups. These are praises of tolerance towards Roman Catholicism, open sympathy for the Catholic faith, and hopes that the Latin Church may help and deliver Byzantium from the Ottoman threat.

These topics are connected not merely by their religious nature, but also by the overwhelmingly positive attitudes that they display towards Catholicism. Negative views are also expressed, but with implicit excuses for the Catholic side, as it can be seen in two letters of Demetrios Kydones. Writing to Symon Atoumanos in 1364 on the low chance of Western military aid, he interprets it as a part of a general phenomenon, a regrettable attitude of contemporary politicians not helping the powerless in their peril. In his letter to his brother, Prochoros Kydones, a fellow Catholic, in 1369-70, stated that the papal curia tended to see 
the troubled situation of Byzantium as a divine punishment for religious error, a claim that probably did not sound baseless for adherents of the Roman Church.

The positive attitudes displayed by these sources seems to be most logical at first glance, supposing that the subjects of tolerance towards Catholicism, sympathy for its teachings and the prospect of Christian solidarity resulting in a Crusade are naturally discussed in pro-Latin polemics. However, this is not the case, as the very same subjects could appear in sources that are highly critical of Catholicism. Calls for tolerance could present the very Christian mindset of staunch Orthodoxy, acknowledgements of 'right' Catholic practices could make attacks on 'wrong' ones more convincing, and hopes for a Crusade as a gesture of solidarity could be satirised as Unionist 'wishful thinking' or a cunning scheme to establish a Union of the Churches. Considering these circumstances, it is rather surprising that the sources discussing the above-mentioned subjects do not contain any anti-Latin arguments at all. 


\section{Summary}

The aim of this study was to present an analysis of generalising presentations of the Latins in selected corpora of Late Byzantine letters, with the help of cultural anthropological methodology. At the end of the study, its results can be summarised in four points.

First of all, a wide range of generalising claims about the characteristics of Westerners is presented within the letters. These remarks can be organised into various categories, ranging from everyday morality through armed conflict to religious beliefs.

Second, the subjects in the letters display a strong overlap with the topics generally discussed in Byzantine discourses about Westerners. There is a striking prevalence of theological issues and secular subjects that were key elements of contrasting being Byzantine and being Latin in the era, corroborating the self-definition of the Byzantines through the representations of the Westerners, just like the practice of azymes in the Catholic Eucharist, or the perception of difference between Byzantine and Western cultural niveau.

The third result involves the attitudes displayed by the authors regarding the subjects they discussed. The sources present a strong division between negative and positive depictions of Westerners. The range of the attitudes voiced in the texts range from harsh condemnations to passionate approvals, both negative and positive depictions tending towards the edges of the spectrum, providing few examples of compromising views, with a majority of negative opinions.

The fourth and final result is connected to the influences behind the attitudes towards the Latins displayed in various letters. Most importantly, the depictions of Westerners in the sources show a very strong correlation with the general attitudes of their respective authors towards the contemporary Catholic world. It meant that 'pro-Latin' authors are rather consequently pro-Latin in their positive remarks concerning Western ethnic groups, while 'anti-Latin' authors are heavily predisposed to present negative depictions of the Latins.

It is worth pointing out that research should not halt at this point. A logical continuation would be a study of the possible mitigating effects on the analysed presentations by the relationship between the author and the addressee, the contemporary situation in which the letter was to be sent and the factor of publicity, as letters in the Byzantine world were not strictly personal texts, as their modern counterparts, but literary products written while being conscious that they would most probably have an audience beyond the addressee. The influence of these factors, however elusive it may be in many cases, deserves further research. 
Similarly, it would be useful to compare the general characteristics of descriptions regarding the Latins in Late Byzantine epistolography with those that preserved the letter corpora of earlier periods, identifying the similarities and differences between subjects and attitudes and seeking explanations for them. Furthermore, detailed comparisons of the aforementioned general characteristics of these depictions with those presented in other Late Byzantine literary genres also offer possible continuations of this study. 


\section{Bibliography}

\section{Text Editions}

ADLER 1928-1935

AdLER, Ada (Ed.): Suidae lexicon, 4 vols. [Lexicographi

Graeci 1.1-1.4. Leipzig: Teubner, 1.1:1928; 1.2:1931;

$1.3: 1933 ; 1.4: 1935]: 1.1: 1-549 ; 1.2: 1-740 ; 1.3: 1-632$;

$1.4: 1-854$.

BALFOUR 1981

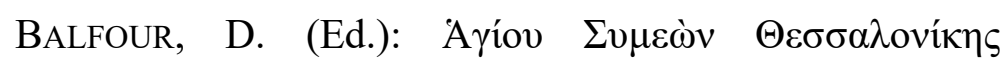

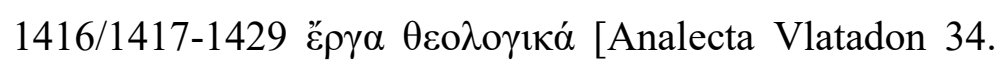
Thessalonike: Patriarchal Institute for Patristic Studies, 1981]: 84-184, 199-246.

BEES 1971-1974

BEES, Nicholas A. (Ed.): “Unedierte Schriftstücke aus der Kanzlei des Johannes Apokaukos des Metropoliten von Naupaktos (in Aetolien)." Byzantinisch-neugriechische Jahrbücher 21 (1971-1974): 57-160.

BosCH 1965

Bosch, Ursula Victoria: Kaiser Andronikos III. Versuch einer Darstellung der byzantinischen Geschichte in den Jahren 1321-1341. Verlag Adolf M. Hakkert, Amsterdam, 1965.

Constantinides-Hero 1983 Constantinides-Hero, A. (Ed.): Letters of Gregory Akindynos [Corpus Fontium Historiae Byzantinae. Series Washingtonensis 21. Washington, D.C.: Dumbarton Oaks, 1983]: 2-304.

DENNIS 1977

DenNIS, George T. (Ed.): Manuelis II Paleologi epistulae. Corpus Fontium Historiae Byzantinae VIII = Dumbarton Oaks Texts IV) Washington D.C. 1977. 
EUSTRATIADES 1910

FESTA 1898

FORSTER 1921-1922

GALLAY 1964-1967

GUTHRIE 1939

HALLIWELL 1995

HALM 1863

HUNGER 1969

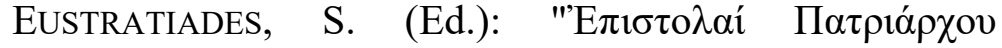

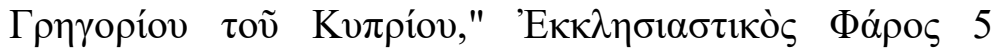
(1910).

FESTA, Niccolo (Ed.): Theodori Ducae Lascaris epistulae CCXVII. Florence, 1898.

Forster, R. (Ed.): Libanii opera X-XI. Leipzig, Teubner, 1921-1922.

Gallay, P. (Ed.), S. Gregoire de Nazianze. Lettres. 2 vols. Paris, Budé, 1964-1967.

Guthrie, W. K. C. (Ed.): Aristotle: On the Heavens. Loeb Classical Library 338. Cambridge (Mass.) - London, Harvard University Press, 1939.

HALliwell, Stephen - FyFE, W. Hamilton - InNES, Doreen C. - RoberTs, W. Rhys (Transls.): Aristotle, Longinus, Demetrius. Poetics. Longinus: On the Sublime. Demetrius: On Style. Revised by Donald A. Russell. Loeb Classical Library 199. Cambridge, MA: Harvard University Press, 1995.

HALM, K. (Ed.): Rhetores Latini minores. Leipzig, Teubner, 1863.

Hunger, Herbert (Ed.): Johannes Chortasmenos (ca. 1370 - ca. 1436/1437). Briefe, Gedichte und kleine Schriften. Einleitung, Regesten, Prosopographie, Text. WBS 7, Wien, 1969. 
JUGIE 1928-1936

KocK 1880

Kolovou 1995

Kolovou 2001

LAMPROS 1910

LAMPROS 1912-1923

LAURENT 1971

LEE 1952

LEONE 1982

LEONE 1991
Jugie, M. - Petit, L. - Siderides, X. A. (Eds.): Oeuvres complètes de Georges (Gennadios) Scholarios, Paris, Maison de la Bonne Presse, 1928-1936.

Kock, T. (Ed.): Comicorum Atticorum fragmenta, vol. 1, Leipzig: Teubner, 1880.

Kolovou, Foteini (Ed.): Euthymios Tornikes als Briefschreiber. JÖB 45 (1995) pp. 53-74.

Kolovou, Foteini (Ed.): Michaelis Choniatae Epistulae. Walter de Gruyter, Berlin - New York, 2001.

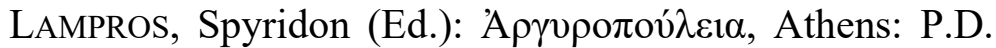
Sakellarios, 1910, pp. 129-141.

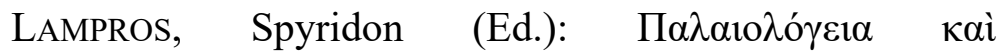

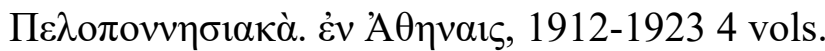

LAurent, Vitalien (Ed.): Les "Mémoires 》 du Grand Ecclésiarque de l'Église de Constantinople Sylvestre Syropoulos sur le concile de Florence (1438-1439), Paris, Centre National de Recherche Scientifique, 1971.

LEE, H. D. P. (Ed.): Aristotle: Meteorologica: Loeb Classical Library 397. Cambridge (Mass.) - London, Harvard University Press, 1952.

LEONE, Pietro Luigi M. (Ed.): Nicephori Gregorae epistulae. I-II. Matino, 1982.

Leone, Pietro Luigi M. (Ed.): Maximi monachi Planudis epistulae. Amsterdam, Hakkert, 1991. 
LOENERTZ 1950

LOENERTZ 1960

LOENERTZ 1964

NRSV

MEYENDORFF 1962

PAPADOPOULOS 1976

PETIT 1923

PITRA 1891
LOENERTZ, Raymond-Joseph (Ed.): Correspondance de Manuel Calecas. Epistolae. Città del Vaticano, Biblioteca Apostolica Vaticana, 1950.

LoEnerTZ, Raymond - Joseph (Ed.): Démétrius Cydonès, Correspondance [Studi e Testi 208. Vatican City: Biblioteca Apostolica Vaticana, 1960]: 1-417.

LOENERTZ, Raymond - Joseph (Ed.): "Lettre de Georges Bardanès, métropolite de Corcyre, au patriarche

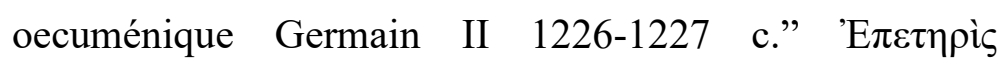

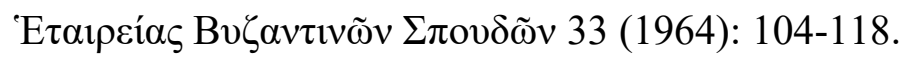

Metzger, Bruce Manning (Ed.): The Bible. New Revised Standard Version with the Apocrypha. Division of Christian Education of the National Council of the Churches of Christ in the USA, 1989.

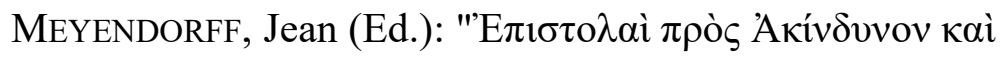

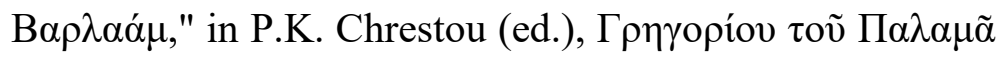

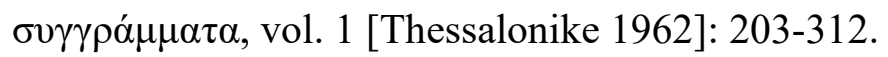

Papadopoulos-Kerameus, Athanasios (Ed.): Noctes Petropolitanae. Sankt-Petersburg, 1913 (Reprint 1976).

Petit, L. (Ed.): Documents relatifs au concile de Florence. II Oeuvres anticonciliaire de Marc d'Ephese. Documents VII-XXIV. (Patrologia Orientalis XVII 2 Nr. 83) Paris 1923 (Reprint Turnhout 1974).

PitrA, J. (Ed.): Analecta sacra e classica spicilegio Solesmensi parata VI (VII) (Juris ecclesiastici graecorum). Paris, 1891. 
PRINZING 2002

RUSSELL 2003

SABBADINI 1915

SCHIRÒ 1954

TOMADAKES 1983-1986

TRAPP 2003

WEICHERT 1910

ZIEGLER 1952
PrinZING, Günter (Ed.): Demetrii Chomateni Ponemata

Diaphora. Berlin - New York, Walter de Gruyter, 2002.

RusSELL, Norman: Palamism and the Circle of Demetrius

Cydones. In Dendrinos, Charalambos - HARris, Jonathan - HARVALIA-CrooK, Eirene - HERrin, Judith (Eds.): Porphyrogenita. Essays on the History and Literature of Byzantium and the Latin East in Honour of Julian Chrysostomides. Aldershot, Ashgate, 2003, pp. 153-174.

SAbBAdini, R. (Ed.): Epistolario di Guarino Veronese, vol. II, Venice, 1915.

SchIRÒ, Giuseppe (Ed.): Barlaam Calabro, Epistole Greche [Istituto Siciliano di Studi Bizantini e Neogreci. Testi e Monumenti 1. Palermo 1954].

TOMADAKES, Nikolaos (Ed.): "'Ек $\tau \tilde{\eta} \varsigma \quad \beta v \zeta \alpha \nu \tau \imath v \tilde{\eta} \varsigma$

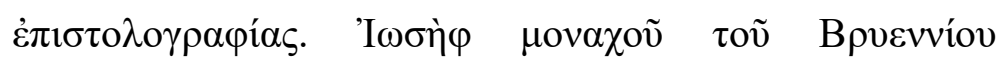

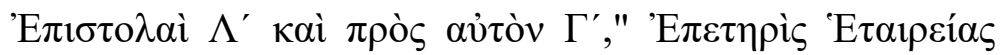

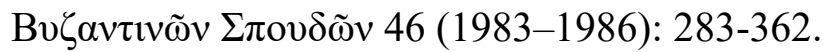

TrAPP, Michael (Ed.): Greek and Latin Letters. An Anthology with Translation. Cambridge, University Press, 2003.

Weichert, V. (Ed.): Demetrii et Libanii quae feruntur 'Typoi epistolikoi' et 'Epistolimaioi characteres'. Leipzig, Teubner, 1910.

ZIEGLER, Adolf W. (Ed.): Die restlichen vier unveröffentlichten Briefe Isidors von Kiev. OCP 18 (1952), pp. 135-142. 


\section{Lexica Grammatica}

LAMPE 1961

LAmpe, G. W. H. (Ed.): A Patristic Greek Lexicon. Oxford, University Press, 1961.

LSJ (9TH EDITION)

LIDDEL, Henry George - ScOTT, Robert - JoneS, Henry Stewart - McKenZIE, Roderick (Eds.): Greek-English Lexicon. Ninth Edition with a Revised Supplement. Oxford, University Press, 1996.

\section{Secondary Literature}

AGOSTI 2001

Agosti, Gianfranco: Late Antique Iambics and Iambikè Idea. In Cavarzere, Alberto - Aloni, Antonio - Barchiesi, Alessandro (Eds.): Iambic Ideas. Essays on a Poetic Tradition from Archaic Greece to the Late Roman Empire. Lanham - Boulder - New York - Oxford, Rowman \& Littlefield Publishers, 2001, pp. 219-255.

AHRWEILER 1975

AHRWEILER, Hélène. L'idéologie politique de l'empire byzantin. Paris: Presses universitaires de France (1975), 1975.

AlBu 2000

AlBU, Emily: Bohemund and the Rooster: Byzantines, Normans, and the Artful Ruse. In Thalia Gouma-Peterson (Ed.): Anna Komnene and Her Times. New York-London, Garland Publishing, 2000. pp. 159-168.

AleXIOU 1991

AleXIOU, Margaret B.-Ševčenko, Nancy Patterson: Hades. In Kazhdan, Alexander - Talbot, Alice-Mary (Eds.): The Oxford Dictionary of Byzantium. New York, Oxford, Oxford University Press, 1991, p. 891. 
ANGELOV 2005

ANGELOV 2007

ANGOLD 1975

ANGOLD 1989

ANGOLD 1995

ANGOLD 2012

ARBEL 1989
ANGELOV, Dimiter: Byzantine Ideological Reactions to the Latin Conquest of Constantinople. In Laiou, Angeliki: Urbs Capta. The Fourth Crusade and its Consequences. La IVe Croisade et ses conséquences. Réalités Byzantines 10. Paris, Lethielleux, 2005, pp. 293-310.

ANGELOV, Dimiter. Imperial Ideology and Political Thought in Byzantium (1204-1330). Cambridge, UK; New York: Cambridge University Press, 2007.

ANGOLD, Michael: Byzantine 'Nationalism' and the Nicean Empire. In BMGS 1975 pp. 49-70.

ANGOLD, Michael: Greeks and Latins After 1204: The Perspective of Exile. In Arbel, Benjamin - Hamilton, Bernard - Jacoby, David (Eds.): Latins and Greeks in the Eastern Mediterranean After 1204. London, Frank Cass, 1989, pp. 63-86.

ANGOLD, Michael: Church and Society in Byzantium under the Comneni, 1081-1261. Cambridge, University Press, 1995.

ANGOLD, Michael: Michael VIII Palaiologos and the Aegean. In Saint-Guillain, Guillaume - Stathakopoulos, Dionysios (Eds.): Liquid and Multiple. Individuals and Identities in the Thirteenth Century Aegean. Paris, ACHCByz, 2012, pp. 27-44.

Arbel, Benjamin: The Cypriot Nobility from the Fourteenth to the Sixteenth Century: A New Interpretation. In Arbel, Benjamin - Hamilton, Bernard Jacoby, David (Eds.): Latins and Greeks in the Eastern 
Mediterranean After 1204. London, Frank Cass, 1989, pp. 175-197.

ASDRACHA 1994

AVVAKUMOV 2002

BALARD 1989

BARKER 1969

BARTH 1969

BARTUSIS 1991

BECK 1977
ASDRACHA, Catherine: Cypriot Culture during the Lusignan Period. Symmeikta 9 (1994), pp. 81-93.

AvvaKumov, Yuri Georgi: Die Entstehung des Unionsgedankens. Die lateinische Theologie des Hochmittelalters in der Auseinandersetzung mit dem Ritus der Ostkirche. Veröffentlichungen des GrabmannInstitutes zur Erforschung der mittelalterlichen Theologie und Philosophie 47. De Gruyter, 2002.

BALARD, Michel: The Genoese in the Aegean (12041566), Mediterranean Historical Review, 4:1 (1989), pp. 158-174.

BARKER, John W.: Manuel II Palaeologus (1391-1425): A Study in Late Byzantine Statesmanship. Rutgers Byzantine Series. New Brunswick, N.J: Rutgers University Press, 1969.

BARTH, Fredrik: Introduction. In BARTH, Fredrik (Ed.): Ethnic Groups and Boundaries. The Social Organisation of Cultural Difference. Bergen, Universitetsforlaget,1969.

Bartusis, Mark C.: Pronoia In Kazhdan, Alexander TAlbot, Alice-Mary (Eds.): The Oxford Dictionary of Byzantium. New York, Oxford, Oxford University Press, 1991, pp. 1733-1734.

BECK, Hans-Georg: Kirche und theologische Literatur im byzantinischen Reich. 2., unveränd. Aufl. Handbuch der 
Altertumswissenschaft Abt. 12, Byzantinisches Handbuch, Teil 2, Bd. 1. München: Beck, 1977.

BERNARD 2011

BERNARD, Floris: 'Greet me with words': Gifts and Intellectual Friendships in Eleventh-century Byzantium. In GRÜNBART, Michael (Ed.): Geschenke erhalten die Freundschaft. Gabentausch und Netzwerkpflege im europäischen Mittelalter. Akten des internationalen Kolloquiums Münster, 19. - 20. November 2009 (= Byzantische Studien und Texte; Bd. 1), Münster / Hamburg / Berlin / London: LIT 2011, pp. 1-11.

BETT 2019

BETT, Richard, "Timon of Phlius", The Stanford Encyclopedia of Philosophy (Winter 2018 Edition), Edward N. Zalta (Ed.), URL = $<$ https://plato.stanford.edu/archives/win2018/entries/timon -phlius/>. Last accessed 5 November 2019.

BEYER 1971 BEYER, Hans-Veit: Nikephoros Gregoras als Theologe und sein Erstes Auftreten gegen die Hesychasten. JÖB 21 (1971), pp. 171-188.

BEYER 1993

BeYer, Hans-Veit: Die Chronologie der Briefe des Maximos Planudes an Alexios Doukas Philanthropenos und dessen Umgebung. REB 51 (1993), pp. 111-137.

BLANCHET 2008

BLANCHET, Marie-Hélène: Georges-Gennadios Scholarios (vers 1400 - vers 1472). Un intellectuel orthodoxe face à la disparition de l'Empire Byzantin. Paris, Institute Français d'Études Byzantines, 2008.

BLANCHET 2009

BlANCHET, Marie-Hélène: George-Gennadios Scholarios et la question de l'addition au symbole. In RigO, Antonio - Ermilov, Pavel (Eds.): Byzantine Theologians. The 
Systematization of Their Own Doctrine and Their Perception of Foreign Doctrines. Università degli Studi di Roma “Tor Vergata”, 2009. Pp. 181-192.

BLONDAL 1978

BREMMER 2003A

BREMMER 2003B

BROWN 2003

BURGMANN 1991

CAMERON 1976

CAMERON 2003
Blondal, Sigfus: The Varangians of Byzantium. Revised by Benedikz, S. Cambridge, University Press, 1978.

Bremmer, Jan N.: Harpies. In HornblOwer, Simon SpAWfORTH, Anthony (Eds.): The Oxford Classical Dictionary. 3rd edition revised. Oxford, University Press, 2003, p. 667.

Bremmer, Jan N.: Phineus. In Hornblower, Simon SPAWFORTH, Anthony (Eds.): The Oxford Classical Dictionary. 3rd edition revised. Oxford, University Press, 2003, p. 1172.

Brown, Andrew L.: Danaus and the Danaids In Hornblower, Simon - SpAwforth, Anthony (Eds.): The Oxford Classical Dictionary. Third Revised Edition. Oxford, University Press, 2003, p. 428.

Burgmann, Ludwig: Hybris. In KazHDAN, Alexander TALBOT, Alice-Mary (Eds.): The Oxford Dictionary of Byzantium, New York-Oxford, Oxford University Press, 1991, p. 959.

Cameron, Alan: Circus Factions: Blues and Greens at Rome and Byzantium. Oxford, 1976.

CAmeron, Averil: How to Read Heresiology? In Journal of Medieval and Early Modern Studies, 33:3, Fall 2003, pp. 471-492. 
Celenza 2001

ChARATZAS 1976

Cheynet 1990

CONGOURDEAU 2009

CONSTANTElos 1992

CONSTANTINE 1973

Coureas 2015
CelenzA, Christopher S.: Piety and Pythagoras in Christian Florence. The Symbolum Nesianum. Studies in the History of Christian Thought CI. Ed.: Bast, Robert J. Brill, Leiden - Boston - Köln, 2001.

Charatzas, St. C.: Les Tzakones. Berlin, 1976.

Cheynet, Jean-Claude: Pouvoir et Contestations à Byzance. Série Byzantina Sorbonensia 9. Paris, Publications de la Sorbonne, 1990.

Congourdeau, Marie-Hélène: Nicolas Cabasilas et la théologie latine. In RigO, Antonio - ERMILOV, Pavel (Eds.): Byzantine Theologians. The Systematization of Their Own Doctrine and Their Perception of Foreign Doctrines. Università degli Studi di Roma "Tor Vergata", 2009, pp. 169-179.

Constantelos, Demetrios J.: Poverty, Society and Philanthropy in the Late Medieval Greek World. New Rochelle, Aristide D. Charatzas, 1992.

Constantine, N: Mark Eugenicus and the Council of Florence. A Historical-Re-evaluation of His Personality. Unpublished doctoral dissertation, Fordham University, 1973.

COUREAS, Nicholas: The Latin and Greek Churches in Former Byzantine Lands under Latin Rule. In Tsougarakis, Nickiphorus - Lock, Peter (Eds.): A Companion to Latin Greece. Boston - Leiden, Brill, 2015, pp. 145-184. 
DARROUZES 1965

DEISSMANN 1923

DELACROIX-BESNIER 2001

DENDRINOS 2019

DENNIS 1960

DENNIS 1988
DARROUZES, Jean: Notes sur Euthyme Tornikès, Euthyme Malakès et Georges Tornikès. REB 23 (1965), pp. 148167.

DeIssman, G. A.: Licht vom Osten.Das Neue Testament und die neuentdeckte Texte der hellenistisch-römischen Welt. Tübingen, 1923 (1895), pp. 193-208.

DelacroiX-Besnier, Claudine: Manuel Calécas et les Frères Chrysobergès, grecs et prêcheurs. In: Actes des congrès de la Société des historiens médiévistes de l'enseignement supérieur public, $32^{\mathrm{e}}$ congrès, Dunkerque, 2001. Les échanges culturels au Moyen Âge, pp. 151-164.

DENDRINOS, Charalambos: Co-operation and friendship among Byzantine scholars in the circle of Emperor Manuel II Palaeologus (1391-1425) as reflected in their autograph manuscripts. Paper given at the conference "Unlocking the Potential of Texts: Interdisciplinary Perspectives on Medieval Greek" at the Centre for Research in the Arts, Social Sciences, and Humanities, University of Cambridge, 18-19 July 2006; (C) 2007, Charalambos Dendrinos. URL: http://www.mml.cam.ac.uk/greek/grammarofmedievalgree k/unlocking/Dendrinos.pdf; last accessed 4th November 2019, pp. 1-17.

DENNIS, George T: The Reign of Manuel II Palaeologus in Thessalonike 1382-1387. Orientalia Christiana Analecta 159, Roma, Pontificale Institutum Orientalium Studiorum, 1960.

DenNIS, George T.: The Byzantines as Revealed in Their Letters. In DufFy, John - PerAdotto, John (Eds.): 
Gonimos. Neoplatonic and Byzantine Studies Presented to Leendert G. Westerink at 75. Buffalo, New York, Arethousa, 1988, pp. 155-165.

DENNIS 2004

DenNIS, George T.: The Late Byzantine Metropolitans of Thessalonike DOP 57 (2004), pp. 255-264.

DoTY 1969

Doty, William G.: The Classification of Epistolary Literature. The Catholic Biblical Quarterly 31 (1969), pp. 183-199.

DOUGLAS 1966

Douglas, Mary: Purity and Danger. An Analysis of Concepts of Pollution and Taboo. Abingdon-on-Thames, Routledge, 1966.

DOWNEY 1957

Downey, Glanville: Themistius and the Defense of Hellenism in the Fourth Century. The Harvard Theological Review, Oct., 1957, Vol. 50, No. 4 (Oct., 1957), pp. 259274.

DÖRRIE 1996

DÖRRIE, Heinrich: Antipodes. In CANCIK, Hubert SCHNEIDER, Helmuth (Eds.): Der Neue Pauly. Enzyklopädie der Antike. Band 1. Metzler, StuttgartWeimar, 1996, p. 788.

EGO 1997

EgO, Beate: Circumcisio. In CANCIK, Hubert SCHNEIDER, Helmuth (Eds.): Der Neue Pauly. Enzyklopädie der Antike. Band 2. Metzler, StuttgartWeimar, 1997, p. 1209.

EPSTEIN 1996

EPSTEIN, Steven A.: Genoa and the Genoese 958-1528. University of North Carolina Press, Chapel Hill \& London, 1996. 
ERIKSEN 1993

FAZZO 2012

FINE 1987

FISHER 2003

FRÖHLICH 1998

FYRIGOS 2005

GEANAKOPLOS 1976
ERIKSEN, Thomas Hylland: Ethnicity and Nationalism: Anthropological Perspectives. Anthropology, Culture, and Society. London, Boulder, Colo: Pluto Press, 1993.

FAzzo, Sylvia: The 'Metaphysics' from Aristotle to Alexander of Aphrodisias. Bulletin of the Institute of Classical Studies, 2012, Vol. 55, No. 1, Ancient Philosophy in Memory of R. W. Sharples (2012), pp. 5168.

FINE, John Jr.: The Late Medieval Balkans. A Critical Survey from the Late Twelfth century to the Ottoman Conquest. Ann Arbor, the University of Michigan Press, 1987.

FiSHER, Nick R. E.: Hubris. In HoRnBlOwer, Simon SPAWFORTH, Anthony (Eds.): The Oxford Classical Dictionary. 3rd edition revised. Oxford, University Press, 2003, pp. 732-733.

FrÖHLICH, Roland: Felix II. In CANCIK, Hubert SCHNEIDER, Helmuth (Eds.): Der Neue Pauly. Enzyklopädie der Antike. Band 4. Metzler, StuttgartWeimar, 1998, p. 464.

FYrigOS, Antonio: Dalla controversia palamitica alla polemica esicastica (con un' edizione critica delle Epistole greche di Barlaam). Antonianum, Roma, 2005.

GeANAKOPlos, Deno John: Western Influence on Byzantium in Theology and Classical Latin Literature. In GeAnAKoplos, Deno John: The Interaction of the 'Sibling' Byzantine and Western Cultures in the Middle 
Ages and the Italian Renaissance (330-1600) New Haven and London, Yale University Press, 1976, pp. 95-117.

GEANAKOPLOS 1989A

GeanaKoplos, Deno John: A Reevaluation of the Influences of Byzantine Scholars on the Development of the Studia Humanitatis, Metaphysics, Patristics, and Science in the Italian Renaissance (1361 - c. 1531). In Geanakoplos, Deno John: Constantinople and the West. Essays on the Late Byzantine (Palaeologan) and Italian Renaissances and the Byzantine and Roman Churches. Madison, The University of Wisconsin Press, 1989, pp. 38-67.

GEANAKOPLOS 1989B

Geanakoplos, Deno John: Italian Renaissance Thought and Learning and the Role of the Byzantine Emigré Scholars in Florence, Rome, and Venice: A Reassessment. In Geanakoplos, Deno John: Constantinople and the West. Essays on the Late Byzantine (Palaeologan) and Italian Renaissances and the Byzantine and Roman Churches. Madison, The University of Wisconsin Press, 1989, pp. 3-37.

GILL 1959

GILL, Joseph: Le concile de Florence. Desclée \& Co., Tournai, Belgium (originally published in English under the title 'The Council of Florence' Cambridge University Press, 1959).

GILL 1964A

GILL, Joseph: Agreement on the Filioque. In GILL, Joseph: Personalities of the Council of Florence. Basil Blackwell, Oxford, 1964, pp. 254-263.

GILL 1964B

GILL, Joseph: George Scholarius. In GILL, Joseph: Personalities of the Council of Florence. Oxford, Basil Blackwell, 1964, pp. 79-94. 
GILL 1964C

GILL 1977

GOUILLARD 1938

GRABAR 1971

GRAF 1998

GRANT 1994

GRÜNBART 2001A

GRÜNBART 2001B

GRÜNBART 2003
GILL, Joseph: John VIII Palaeologus. A Character Study. In GILL, Joseph: Personalities of the Council of Florence. Oxford, Basil Blackwell, 1964. pp. 104-124.

GILL, Joseph: The Tribulations of the Greek Church in Cyprus 1196-c. 1280. Byzantinische Forschungen V (1977), pp. 73-93.

GOUILLARD, Jean: Les influences latines dans l'oeuvre théologique de Manuel Calécas. In Échos d'Orient, tome $37, \mathrm{n}^{\circ} 189-190$ (1938), pp. 36-52.

GRABAR, André: L'empereur dans l'art byzantin. Paris, Les Belles Lettres, 1936 (reprint London, 1971).

GRAF, Fritz: Herakles. In CANCIK, Hubert - SCHNEIDER, Helmuth (Eds.): Der Neue Pauly. Enzyklopädie der Antike. Band 5. Metzler, Stuttgart-Weimar, 1998, pp. 387-394.

GRANT, Edward: Planets, Stars and Orbs. The Medieval Cosmos 1200-1687. Cambridge, University Press, 1994 [Reprint 1996].

GRÜNBART, Michael: Epistularum Byzantinarum Initia. Hildesheim et al., 2001.

GRÜNBART, Michael: Ferngespräche - Zum Briefschreiben im ausgehenden zehnten Jahrhundert. Byzantina 22 (2001), pp. 25-46.

GRÜNBART, Michael: Beobachtungen zur byzantinischen Briefrhetorik. In Odorico, Paolo (Ed.): Épistolographie et 
la Poésie Épigrammatique. Actes de la 16e Table ronde du XX Congrès international des Études byzantines, Paris 2001. Paris, Centre d'études byzantines, néo-helléniques et sud-est européennes, École des Hautes Études en Sciences Sociales, 2003, pp. 31-41.

GRÜNBART 2005A

GRÜNBART, Michael: Byzantinisches Rednerideal? Anmerkungen $\mathrm{zu}$ einem kaum beachteten Aspekt mittelgriechischer Beredsamkeit. In KOFLER W. KorenjaK M. - Tilg S. - Töchterle, K (Hrsg.): Pontes III: Die antike Rhetorik in der europäischen Geistgeschichte. (Comparanda. Literaturwissenschaftliche Studien zu Antike und Moderne). Innsbruck, 2005, pp. 103-114.

GRÜNBART 2005B

GRÜNBART, Michael: Der byzantinische Brief und der Raum. In Virtuelle Räume. Raumwahrnehmung und Raumvorstellung im Mittelalter. Akten des 10. Symposiums des Mediävistenverbandes, Krems, 24-26. März, 2003. Berlin, Akademie Verlag, 2005, pp. 343-355.

GRÜNBART 2005C

GRÜNBART, Michael: Formen der Anrede im byzantinischen Brief vom 6. bis zum 12. Jahrhundert. Wien, Verlag der Österreichischen Akademie der Wissenschaften, 2005.

GRÜNBART 2010A

GRÜNBART, Michael: Aspekte der Waren- und Informationsaustauschs in personalen Netzwerken. Byzantion 80 (2010), pp. 157-172.

GRÜNBART 2010B

GRÜNBART, Michael: Zusammenstellen vs Zusammenstehlen. Zum Traditionsverständnis in der byzantinischen Kultur. In RHOBY, Andreas - SCHIFFER, Elisabeth (Eds.): Imitatio - Aemulatio - Variatio. Akten 
des internationalen wissenschaftlichen Symposiums zur byzantinischen Sprache und Literatur (Wien, 22.-25. Oktober 2008) (Veröffentlichungen zur Byzanzforschung 21). Wien, Österreichische Akademie der Wissenschaften, 2010, pp. 129-136.

GRÜNBART 2014

GRÜNBART, Michael: Paideia Connects: The Interaction Between Teachers and Pupils in Twelfth Century Byzantium. In STECKel, Sita - GAUL, Niels - GrÜNBART, Michael (Eds.): Networks of Learning. Perspectives on Scholars in Byzantine East and Latin West, c. 1000-1200. Münster, LIT Verlag, 2014, pp. 17-31.

HADOT 1992

HADOT, Ilsetraut: Aristote dans l'enseignement philospohique néoplatonicien: Les préfaces des commentaires sur les Catégories. Revue de Théologie et de Philosophie, Troisième série, Vol. 124, No. 4 (1992), pp. 407-425.

HATLIE 1996A

Hatlie, Peter: Life and Artistry in the 'Publication' of Demetrios Kydones' Letter Collection. GRBS 37 (1996), No. 1, pp. 75-102.

HATLIE 1996B

Hatlie, Peter. 'Redeeming Byzantine Epistolography'. BMGS, no. 20 (1996), pp. 213-48.

HARRIS 2003

HARRIS, Jonathan: Byzantium and the Crusades. Hambledon Continuum, New York, 2006 (First edition: 2003).

HEIM 1998

HeIM, Manfred: Liberius. In CANCIK, Hubert SchneIDER, Helmuth (Eds.): Der Neue Pauly. Enzyklopädie der Antike. Band 7. Metzler, StuttgartWeimar, 1998, p. 144. 
HENDY 1985

HERMAN 1951

HERRIN 1975

HERRIN 2013

HILD 1976

HINTERBERGER 2011

HUFFMAN 1993
HENDY, Michael F.: Studies in Byzantine Monetary Economy, c. 300-1450. Cambridge, University Press, 1985.

Herman, E.: Hat die Byzantinische Kirche von selbst eintretende Strafen (poenae latae sententiae) gekannt? BZ 44 (1951), pp. 258-264.

HERrin, Judith: Realities of Byzantine Provincial Government: Hellas and Peloponnesos, 1180-1205. Dumbarton Oaks Papers, Vol. 29 (1975), pp. 253-284.

Herrin, Judith - McManus, Stuart M.: Renaissance Encounters: Byzantium Meets the West at the Council of Ferrara-Florence in 1438-1439. In BROwnLEE, Marina S. - GondiCAS, Dimitri H. (Eds.): Renaissance Encounters: Greek East and Latin West. Leiden, Brill, 2013, pp. 35-56.

HILD, Friedrich: Belechatuïa. In KodER, Johannes - HILD, Friedrich: Tabula Imperii Byzantini Bd. 1. Österreichische Akademie der Wissenschaften Philosophisch-Historische Klasse Denkschriften. Bd. 125. Wien, Österreichische Akademie der Wissenschaften, 1976, p. 133.

Hinterberger, Martin: A Neglected Tool of Orthodox Propaganda? The Image of the Latins in Byzantine Hagiography. In HinTERBERGER, Martin - SCHABEL, Chris (Eds.): Greeks, Latins and Intellectual History 1204-1500. Leuven - Paris - Walpole, MA, Peeters, 2011.

Huffman, Carl A.: Philolaus of Croton. Pythagorean and Presocratic. A Commentary on the Fragments and 
Testimonia with Interpretative Essays. Cambridge, University Press, 1993.

HUNGER 1965

HUNGER 1969-1970

HUNGER 1978

ILIEVA 1991

IRMSCHER 1991

ISNENGHI 2008
Hunger, Herbert: Reich Der Neuen Mitte. Der christlichen Geist der byzantinischen Kultur. Wien, Köln, Verlag Styria, 1965, pp. 340-344.

Hunger, Herbert: On the Imitation (MIMH $\Sigma \mathrm{I} \Sigma)$ of Antiquity in Byzantine Literature. DOP 23-24 (1969-70), pp. 17-38.

Hunger, Herbert: Die hochsprachliche profane Literatur der Byzantiner. Byzantinisches Handbuch: Handbuch der Altertumswissenschaft, 12.5. 2 Bde. München 1978.

ILIEVA, Aneta: Frankish Morea (1205-1262) Sociocultural Interaction between the Franks and the Local Population. Historical Publications 9. Athens, S. D. Basilopoulos, 1991.

IRMSCHER, Johannes - WEYL Carl, Annamarie: Judas Iscariot. In KAZHDAN, Alexander - TALBOT, Alice-Mary (Eds.): The Oxford Dictionary of Byzantium. New York, Oxford, Oxford University Press, 1991, pp. 1077-1078.

ISNENGHI. Laura: La quarta crociata e la questione dell'identita. Spunti per una lettura di alcune fonti bizantine e occidentali, da Nicola Mesarite a Martin da Canal. In PiAtTI, P. (Ed.): The Fourth Crusade Revisited 1204-2004. Andros (Greece), 27-30 May 2004. Citta del Vaticano, 2008, pp. 104-126. 
JANIN 1975

JONES 1971

JUGIE 1912

KALDELLIS 2007

KALDELLIS 2009

KALDELLIS 2012

KALDELLIS 2013

KARAMANOLIS 2004
JANIN, Raymond: Les églises et les monastères des grands centres byzantins. Paris, Institut Français des Études Byzantines, 1975.

JONES, W. R.: The Image of the Barbarian in Medieval Europe. Comparative Studies in Society and History, Vol. 13, No. 4 (Oct., 1971), pp. 376-407.

JugIE, Martin: La vie et les oeuvres d'Euthyme Zigabène. In: Échos d'Orient, tome 15, N94 (1912) pp. 215-225.

Kaldellis, Anthony: Hellenism in Byzantium. The Transformations of Greek Identity and the Reception of the Classical Tradition. Cambridge, University Press, 2007.

KALDELLIS, Anthony: The Christian Parthenon. Classicism and Pilgrimage in Byzantine Athens. Cambridge, University Press, 2009.

KALDELlis, Anthony: From Rome to New Rome, from Empire to Nation-State: Reopening the Question of Byzantium's Roman Identity, in Grig, Lucy and Kelly, Gavin (Eds.), Two Romes: Rome and Constantinople in Late Antiquity (Oxford, 2012), pp. 387-404.

KALDELLIS, Anthony. Ethnography after Antiquity: Foreign Lands and Peoples in Byzantine Literature. Empire and After. Philadelphia: University of Pennsylvania Press, 2013.

KARAMAnOLIS, George: Porphyry: The First Platonist Commentator on Aristotle. Bulletin of the Institute of Classical Studies. Supplement, 2004, No. 83, Philosophy, 
Science and Exegesis in Greek, Arabic and Latin Commentaries: Volume One (2004), pp. 97-120.

KARPOZELOS 1973

KIANKA 1981

KIANKA 1985

KIANKA 1995

KODER 1976A

KODER 1976B
Karpozelos, Apostolos: The Ecclesiastical Controversy between the Kingdom if Nicea and the Principality of Epiros (1217-1233). Thessalonike, KENTPON

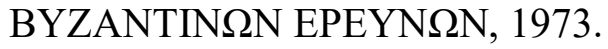

KIANKA, Frances: Demetrius Cydones: Intellectual and Diplomatic Relations between Byzantium and the West in the Fourteenth Century. New York, Fordham University, 1981.

KIANKA, Frances: Byzantine-Papal Diplomacy: The Role of Demetrius Cydones. The International History Review, Vol. 7, No. 2 (May 1985), pp. 175-213.

KIANKA, Frances: Demetrios Kydones and Italy. Dumbarton Oaks Papers, Vol. 49, Symposium on Byzantium and the Italians, 13th-15th Centuries (1995), pp. 99-110.

KodER, Johannes: Bela. In KoDER, Johannes - Hild, Friedrich: Tabula Imperii Byzantini Bd. 1. Österreichische Akademie der Wissenschaften Philosophisch-Historische Klasse Denkschriften. Bd. 125. Wien, Österreichische Akademie der Wissenschaften, 1976. p. 132.

KoDER, Johannes: Euripos. In KoDER, Johannes - HILD, Friedrich: Tabula Imperii Byzantini Bd. 1. Österreichische Akademie der Wissenschaften Philosophisch-Historische Klasse Denkschriften. Bd. 125. Wien, Österreichische Akademie der Wissenschaften, 1976. pp. 156-158, p. 156. 
KODER 1976C

KODER 1976D

KODER 1976E

KODER 1976F

KODER 1976G

KODER $1976 \mathrm{H}$
KoDER, Johannes: Hos. Meletios. In KoDER, Johannes HILD, Friedrich: Tabula Imperii Byzantini Bd. 1. Österreichische Akademie der Wissenschaften Philosophisch-Historische Klasse Denkschriften. Bd. 125. Wien, Österreichische Akademie der Wissenschaften, 1976, pp. 217-218.

KoDER, Johannes: Hymettos. In KoDER, Johannes - HILD, Friedrich: Tabula Imperii Byzantini Bd. 1. Österreichische Akademie der Wissenschaften Philosophisch-Historische Klasse Denkschriften. Bd. 125. Wien, Österreichische Akademie der Wissenschaften, 1976. p. 174.

Koder, Johannes: Karystos. In KodER, Johannes - HILD, Friedrich: Tabula Imperii Byzantini Bd. 1. Österreichische Akademie der Wissenschaften Philosophisch-Historische Klasse Denkschriften. Bd. 125. Wien, Österreichische Akademie der Wissenschaften, 1976, pp. 183-184.

Koder, Johannes: Makre. In Koder, Johannes - Hild, Friedrich: Tabula Imperii Byzantini Bd. 1. Österreichische Akademie der Wissenschaften Philosophisch-Historische Klasse Denkschriften. Bd. 125. Wien, Österreichische Akademie der Wissenschaften, 1976, p. 210.

KodER, Johannes: Neai Patrai. In KodER, Johannes HILD, Friedrich: Tabula Imperii Byzantini Bd. 1. Österreichische Akademie der Wissenschaften Philosophisch-Historische Klasse Denkschriften. Bd. 125. Wien, Österreichische Akademie der Wissenschaften, 1976. pp. 221-222.

KoDER, Johannes: Negroponte. Untersuchungen zur Topographie und Siedlungsgeschichte der Insel Euboia 
während der Zeit der Venezianerherrschaft. Wien, Verlag der Österreicischen Akademie der Wissenschaften, 1976.

KODER 1976I

Koder, Johannes: Salona. In Koder, Johannes - HILd, Friedrich: Tabula Imperii Byzantini Bd. 1. Österreichische Akademie der Wissenschaften Philosophisch-Historische Klasse Denkschriften. Bd. 125. Wien, Österreichische Akademie der Wissenschaften, 1976. p. 254.

KODER 2011

KODER, Johannes: Byzantium as Seen by Itself - Images and Mechanisms at Work, in: Proceedings of the 22nd International Congress of Byzantine Studies Sofia, 22-27 August 2011, I. Plenary Papers (Sofia, 2011), pp. 69-81.

KOLBABA 2000

KolbABA, Tia M.: The Byzantine Lists: Errors of the Latins. Illinois Medieval Studies. Urbana: University of Illinois Press, 2000.

LAIOU 1972

LAIOU, Angeliki E.: Constantinople and the Latins: The Foreign Policy of Andronicus II, 1282-1328. Cambridge, Mass., 1972.

LAIOU 1978

LAIOU, Angeliki: Some Observations on Alexios Philanthropenos and Maximos Planoudes. BMGS 4 (1978), pp. 89-99.

LAIOU 1982

LAIOU, Angeliki: The Greek Merchant of the Palaeologan Period: A Collective Portrait. The Proceedings of the Academy of Athens, 1982, pp. 96-124.

LAIOU 1984

LAIOU, Angeliki: Contribution à l'étude de l'institution familiale en Épire au XIIIème siècle. Fontes Minores (Forschungen zur byzantinischen Rechtsgeschichte) VI (1984), pp. 275-323. 
LAIOU 1992

LAIOU 1996

LAIOU 2012

LEMERLE 1957

LEONTE 2013

LITTLEWOOD 1976
LAIOU, Angeliki: Mariage, amour et parenté à Byzance aux XIe-XIIIe siècles. Travaux et Mémoires du Centre de Recherche d'Histoire et Civilisation de Byzance, Collège de France, Monographies 7. Paris, De Boccard, 1992.

LAIOU, Angeliki: The Correspondence of Gregorios II Kyprios as a Source for the History of Social and Political Behavior in Byzantium or, on Government by Rhetoric. In SEIBT, Werner (Ed.): Geschichte und Kultur der Palaiologenzeit. Wien, Verlag der Österreichischen Akademie der Wissenschaften, 1996, pp 91-108.

LAIOU, Angeliki: Monopoly and Privileged Free Trade in the Eastern Mediterranean. In LAIOU, Angeliki: Byzantium and the Other. Relations and Exchanges, Farnham, 2012, pp. 511-526.

LEMERLE, Paul: L'émirat d'Aydin, Byzance et l'Occident: recherches sur "La geste d'Umur Pacha", Paris, Presses Univ. de France; 1957.

LEONTE, Florin: A Brief History of the Morea seen Through the Eyes of an Emperor-Rhetorician. Manuel II Palaiologos's Funeral Oration for Theodore, Despot of Morea. In Gerstel, Sharon E. J. (Ed.): Viewing the Morea. Land and People in the Late Medieval Peloponnese. Washington DC, Dumbarton Oaks Research and Library Collection, 2013, pp. 397-417.

LiTTLEWOOD, Anthony: An 'Ikon of the Soul': The Byzantine Letter. In Visible Language 10 (1976), pp. $197-$ 226. 
LITTLEWOOD 1988

LOCK 2014

LOENERTZ 1949

LONGNON 1937

LOWDEN 1991

LUTTRELL 1989

MACRIDES 1994

LitTLEWOOD, Anthony: A Statistical Survey of the Incidence of Repeated Quotations in Selected Byzantine Letter-writers. In Duffy, John - Peradotto, John (Eds.): Gonimos. Neoplatonic and Byzantine Studies Presented to Leendert G. Westerink at 75. Buffalo, New York, Arethousa, 1988, pp. 137-154.

LocK, Peter. The Franks in the Aegean: 1204-1500. Longman, London and New York, 2014.

LoENERTZ, Raymond-Joseph: Pour la chronologie des œuvres de Joseph Bryennios. REB 7 (1949), pp. 12-32.

LONGNON, Jean: Les Autremencourt, seigneurs de Salona en Grèce (1204-1311)". Bulletin de la Société historique de Haute-Picardie XV (1937), pp. 15-46.

Lowden, John H. - IRMSChER, Johannes - CUTLER, Anthony: David. In KAZHDAN, Alexander - TALBOT, Alice-Mary (Eds.): The Oxford Dictionary of Byzantium, New York-Oxford, Oxford University Press, 1991, pp. 588-599.

LutTRELl, Anthony T.: The Latins and Life on the Smaller Aegean Islands, 1204-1453. In ARBEL, Benjamin - HAMILTON, Bernard - JACOBY, David (Eds.): Latins and Greeks in the Eastern Mediterranean After 1204. London, Frank Cass, 1989, pp. 146-157.

MACRIDES, Ruth: From the Komnenoi to the Palaiologoi: Imperial Models in Decline and Exile. In MagdaLino, Paul (Ed.): New Constantines. The Rythm of Imperial Renewal in Byzantium 4th-13th Centuries. Ashgate, Aldershot, 1994, pp. 269-282. 
MACRIDES, Ruth. '1204: The Greek Sources'. In LAIOU, Angeliki: Urbs Capta. The Fourth Crusade and its Consequences. La IVe Croisade et ses conséquences. Réalités Byzantines 10. Paris, Lethielleux, 2005, pp. 141150.

MAGDALINO 1977

MAGDALINO 1989

MAGDALINO 2010

MALATRAS 2011

MATSCHKE 1992
Magdalino, Paul: A Neglected Authority for the History of the Peloponnese in the Early Thirteenth Century: Demetrios Chomatenos, Archbishop of Bulgaria. BZ 70 (1977), pp. 316-323.

Magdalino, Paul: Honour among Romaioi: The Framework of Social Values in the World of Digenes Akritas and Kekaumenos. BMGS 13 (1989), pp. 183-218.

Magdalino, Paul: Orthodoxy and Byzantine Cultural Identity. In Rigo, Antonio - ERMILOv, Pavel (Eds.): Orthodoxy and Heresy in Byzantium. The Definition and the Notion of Orthodoxy and Some Other Studies on the Heresies and the Non-Christian Religions. Università degli Studia di Roma “Tor Vergata”, 2010 pp. 21-40.

MalatRAS, Christos: The Making of an Ethnic Group: The Romaioi in the 12th-13th Centuries, in DiMADIS, Konstantinos A. (Ed.), Identities in the Greek World (From 1204 to the Present Day), Proceedings of the 4th European Congress of Modern Greek Studies, Granada, 912 September 2010 (Athens, 2011) pp. 419-430.

MAtschKe, Klaus-Peter: The Notaras Family and Its Italian Connections. DOP 49 (1992), pp. 59-72. 
MERCATI 1929

MESSIS 2011

MEYENDORFF 1954

MEYENDORFF 1979

MEYENDORFF 1990

MEYENDORFF 1991A

MEYENDORFF 1991B

MitsIOU 2015
Mercati, Angelo: Giovanni Ciparissiota alla corte di Gregorio XI (Novembre 1376-Dicembre 1377) BZ 30 (1929), pp. 496-501.

Messis, Charis: Lectures sexuées de l'altérité. Les Latins et identité romaine menacée pendant les derniers siècles des Byzance. JÖB 61 (2011), pp. 151-170.

MEYENDORFF, Jean: L'origine de la controverse palamite. La première lettre de Palamas à Akindynos. Theologia XXV (1954), Athens, pp. 602-630.

MeyendorfF, John: The Holy Trinity in Palamite Theology. In FAHEY, Michael A. - MeYEndorfF, John: Trinitarian Theology East and West. St. Thomas Aquinas - St. Gregory Palamas. Holy Cross Orthodox Press, 1979. pp. 25-43.

MeYendorfF, John: Christian Marriage in Byzantium: The Canonical and Liturgical Tradition. DOP 44 (1990), pp. 99-107.

MeYendorfF, John: Azymes. In KazHDAn, Alexander TAlbot, Alice-Mary (Eds.): The Oxford Dictionary of Byzantium. Oxford University Press, 1991. p. 241.

MeyendorfF, John: Filioque. In KaZHDAN, Alexander TAlbot, Alice-Mary (Eds.): The Oxford Dictionary of Byzantium. Oxford University Press, 1991. pp. 785-786.

Mitsiou, Ekaterini: The Byzantines and the "Others". Between "Transculturality" and Discrimination. In GAstgeber, Christian - DAim, Falko (Eds.): Byzantium as Bridge between West and East. Wien, Verlag der 
Österreichischen Akademie der Wissenschaften, 2015, pp. $65-74$.

MuLlett 1981

Mullett, Margaret: The Classical Tradition in the Byzantine Letter. In MulletT, Margaret - ScOTT, Roger (Eds.): Byzantium and the Classical Tradition. University of Birmingham Thirteenth Spring Symposium of Byzantine Studies, 1979. Centre of Byzantine Studies, University of Birmingham, 1981, pp. 75-93.

MuLLETT 1984

MulLetT, Margaret: Aristocracy and Patronage in the Literary Circles of Comnenian Constantinople. In Angold, M. (Ed.): The Byzantine Aristocracy IX to XIII Centuries. Papers of the Sixteenth Spring Symposium of Byzantine Studies (Edinburg, March 1982). Oxford, BAR, 1984, pp. 173-201.

MuLLETT 1990

MuLLETT, Margaret: Writing in Early Mediaeval Byzantium. In MCKITTERICK, Rosamond (Ed.): The Uses of Literacy in Early Mediaeval Europe. Cambridge, University Press, 1990, pp.156-185.

MULLETT 1997

MuLLETT, Margaret: Theophylact of Ochrid. Reading the Letters of a Byzantine Archbishop. Aldershot, Ashgate Variorum, 1997.

MuLletT 1999

MulLETT, Margaret: Friendship in Byzantium: Genre, Topos and Network. In HASELDINE, Julian (Ed.): Friendship in Medieval Europe. Phoenix Mill, Sutton Publishing Limited, 1999, pp. 166-184.

MuLLETT 2003A

MulLeTT, Margaret: Rhetoric, Theory and the Imperative of Performance: Byzantium and Now. In JEFFREYS, Elisabeth (Ed.): Rhetoric in Byzantium. Papers from the 
Thirty-fifth Spring Symposium of Byzantine Studies, Exeter College (University of Oxford, March 2001). Aldershot, Ashgate, 2003, pp. 151-170.

Mullett 2003B

NAJEMY 2008

NiCOL 1957

NiCOL 1964

NiCOL 1965

NiCOL 1966
MulletT, Margaret: The Detection of Relationship in Middle Byzantine Literary Texts: The Case of Letters and Letter-Networks. In ODORICO, Paolo (Ed.): Épistolographie et la Poésie Épigrammatique. Actes de la 16e Table ronde du XX Congrès international des Études Byzantines, Paris 2001. Paris, Centre d'Études Byzantines, Néo-helléniques et Sud-est Européennes, École des Hautes Études en Sciences Sociales, 2003, pp. 63-74.

NAJEMY, John M.: A History of Florence, 1200-1575. Malden, Massachussets, Wiley-Blackwell, 2008 (1st edition).

Nicol, Donald M.: The Despotate of Epirus, Oxford, Basil Blackwell, 1957.

NiCOL, Donald M.: Mixed Marriages in Byzantium in the Thirteenth Century. In Dugmore, C. W. - Duggan, C. (Eds.): Studies in Church History I. Oxford - Edinburgh, 1964, pp. 160-172.

NicOL, Donald M.: Constantine Akropolites: A Prosopographical Note. DOP 19 (1965), pp. 249-256.

NiCOL, Donald M.: The Fourth Crusade and the Greek and Latin Empires 120-1261 In Hussey, J. M. (Ed.): The Cambridge Medieval History IV: The Byzantine Empire, part 1: Byzantium and its Neighbours. Cambridge, 1966, pp. $275-330$. 
NiCOL 1968

NiCOL 1976

NiCOL 1979

NICOL 1992

PAGE 2008

PAPADAKIS 1991

PAPADAKIS 1994

PAPADAKIS 2011
NICOL, Donald M.: Byzantine Requests for an Oecumenical Council in the Fourteenth Century. Annuarium Historiae Conciliorum I (1968), pp. 69-95.

NicOL, Donald M.: Refugees, Mixed Populations and Local Patriotism in Epiros and Western Macedonia after the Fourth Crusade. In XVe Congrès international d'études byzantines. Athens, 1976, pp. 1-33.

NicOL, Donald M.: Symbiosis and Integration. Some Greco-Latin Families in Byzantium in the 11th to 13th Centuries. Byzantinische Forschungen VII (1979), pp. 113-135.

NicOL, Donald M.: The Immortal Emperor: The Life and Legend of Constantine Palaiologos, Last Emperor of the Romans. Cambridge, University Press, 1992.

Page, Gill: Being Byzantine. Greek Identity before the Ottomans. Cambridge, UK; New York, Cambridge University Press, 2008.

PAPADAKIS, Aristeides: Anathema. In KAZHDAN, Alexander - TALBOT, Alice-Mary (Eds.): The Oxford Dictionary of Byzantium. New York, Oxford, Oxford University Press, 1991, p. 89.

PAPADAKIS, Aristeides: The Christian East and the Rise of the Papacy: The Church 1071-1453. New York, Crestwood, 1994.

PAPADAKIS, Aristeides: The Byzantines and the Rise of the Papacy: Points for Reflection, 1204-1453. In Hinterberger, Martin - Schabel, Chris (Eds.): Greeks, 
Latins and Intellectual History 1204-1500. Leuven - Paris

- Walpole, MA, Peeters, 2011, pp. 19-42.

PINGREE 1976

PINGREE, David: The Byzantine Version of the Toledan Tables: The Work of George Lapithes? DOP 30 (1976), pp. 86-132.

PODSKALSKY 1977

PRINZING 1973

PRINZING 1982

RAPP 2008

RHOBY 2003

RHOBY 2007
PODSKALSKY, Gerhard: Theologie und Philosophie in Byzanz. Der Streit um die theologischr Methodik in der spätbyzantinischen Geistesgeschichte (14./15. Jh.), seine systematischen Grundlagen und seine historische Entwicklung. Byzantinisches Archiv 15. C. H. Bech'sche Verlagsbuchhandlung, München, 1977.

PrINZING, Günter: Der Brief Kaiser Heinrichs von Konstantinopel vom 13. Januar 1212. Byzantion 43 (1973), pp. 395-431.

PRINZING, Günter: Sozialgeschichte der Frau im Spiegel der Chomatenos-Akten. JÖB 32.2 (1982), pp. 453-462.

RAPP, Claudia: Hellenic Identity, Romanitas, and Christianity in Byzantium. In: ZACHARIA, Katerina (ed.), Hellenisms. Culture, Identity and Ethnicity from Antiquity to Modernity (Aldershot, 2008) pp. 127-147.

RhOBY, Andreas: Reminiszenzen an antike Stätten in der mittel- und spätbyzantinischen Literatur. Eine Untersuchung zur Antikenrezeption in Byzanz. Göttingen, Peust \& Gutschmidt Verlag, 2003.

RHOBY, Andreas: Aspekte des Fortlebens von Gregory von Nazianz in byzantinischer und postbyzantinischer Zeit. In GRÜNBART, Michael: Theatron. Rhetorische 
Kultur in Spätantike und Mittelalter Rhetorical Culture in Late Antiquity and the Middle Ages Berlin - New York, De Gruyter, 2007, pp. 409-418.

RHOBY 2013

RHOвY, Andreas: Byzantine Greek Words in English Vocabulary? With an Appendix on Byzantine Terms for 'English'. In JuHÁsz, Erika (Ed.): Byzanz und das Abendland: Begegnungen zwischen Ost und West. Budapest, Eötvös-József-Collegium, 2013, pp. 53-69.

ROLLO 2002

Rollo, Antonio: Problemi e prospettive della ricerca su Manuele Crisolora. In MAISANO, Riccardo - Rollo, Antonio (Eds.): Manuele Crisolora e il ritorno del greco in Occidente: atti del Convegno internazionale, Napoli, 2629 giugno 1997. Napoli, Istituto universitario orientale. Dipartimento di studi del mondo classico e del mediterraneo antico, 2002, pp. 31-86.

RUNCIMAN 1955

Runciman, Steven. The Eastern Schism. A Study of the Papacy and the Eastern Churches During the XIth and XIIth Centuries. Oxford, Clarendon Press, 1955.

RUNCIMAN 1986

Runciman, Steven: The Great Church in Captivity: A Study of the Patriarchate of Constantinople from the Eve of the Turkish Conquest to the Greek War of Independence. Cambridge University Press, 1986.

RYDER 2010

RYDER, Judith R.: The Career and Writings of Demetrius Kydones. A Study of Fourteenth-Century Byzantine Politics, Religion and Society. Leiden - Boston, Brill, 2010.

RYDER 2012A

RYDER, Judith T.: Byzantium and the West in the 1360s:

The Kydones Version. In HARRIS, Jonathan - HoLMES, 
Catherine - Russell, Eugenia: Byzantines, Latins, and Turks in the Eastern Mediterranean World after 1150. Oxford University Press, 2012. pp. 345-366.

RYDER 2012B

RYDER, Judith R.: Catholics in the Byzantine Political Elite: The Case of Demetrius Cydones. In LAMBERT, Sarah - NichOLSON, Helen (Eds.): Languages of Love and Hate: Conflict, Communication and Identity in the Medieval Mediterranean. Brepols, Turnhout, 2012, pp. 159-174.

SCHABEL 2011

SchABEL, Chris: The Quarrel over Unleavened Bread in Western Theology 1234-1439. In HinTERBERGER, Martin - SchABEL, Chris (Eds.): Greeks, Latins and Intellectual History 1204-1500. Leuven - Paris - Walpole, MA, Peeters, 2011, pp. 85-127.

SCHMIDT 2016

SCHMIDT, Tristan: Protective and Fierce: The Emperor as a Lion in Contact with Foreigners and his Subjects in Twelfth and Early Thirteenth-Century Byzantine Court Literature. In STEWART, Kirsty - WAKELEY, James Moreton (Eds.): Cross-Cultural exchange in the Byzantine World, c. 300-1500 AD. Byzantine and Neohellenic Studies vol. 14. (2016) Edited by LouTH, Andrew RICKS, David. Peter Lang, Oxford - Bern - Berlin Bruxelles - Frankfurt am Main - New York - Wien, pp. 159-173.

SCHMIDT 2019

SCHMIDT, Tristan: Noble Hounds for Aristocrats, Stray Dogs for Heretics. In SCHMIDT, Tristan - PAHLITZSCH, Johannes: Impious Dogs, Haughty Foxes and Exquisite Fish: Evaluative Perception and Interpretation of Animals in Ancient and Medieval Mediterranean Thought. Berlin Boston, De Gruyter, 2019, pp. 105-133. 
SCHMITT 1968

SETTON 1956

SETTON 1975

SIECINSKI 2010

SIMON 1986

SMARNAKIS 2015

SMITH 1978

SMITH 1986
SchMITT, Wolfgang O.: Lateinische Literatur in Byzanz. Die Überestzungen des Maximos Planoudes und die moderne Forschung. JÖB 17 (1968), pp. 127-147.

SEtTon, Kenneth M.: The Byzantine Background to the Italian Renaissance. Proceedings of the American Philosophical Society, Vol. 100, No. 1 (Feb. 24, 1956), pp. $1-76$.

Setton, Kenneth M.: Catalan Domination of Athens, 1311-1388. Variorum, London, 1975.

SIECINSKI, Anthony Edward: The Filioque: History of a Doctrinal Controversy. Oxford, University Press, New York - Oxford, 2010.

SIMON, Dieter: Das Ehegüterrecht der Pira. Ein systematischer Versuch.Forschungen zur byzantinischen Rechtsgeschichte. Fontes minores VII, Löwenklau Gesellschaft e.V., Frankfurt a. Main, 1986, pp. 193-238.

SMARNAKIS, Ioannis: Rethinking Roman Identity after the Fall (1453): Perceptions of >Romanitas $২$ by Doukas and Sphrantzes, Byzantina Symmeikta 25 (2015), pp. 211-234.

Smith, Mahlon H.: And Taking Bread... Cerularius and the Azymes Controversy of 1054. Éditions Beauchesne, Paris, 1978.

Smith, Anthony D.: The Ethnic Origins of Nations. Oxford, 1986. 

among the Persons of the Trinity in Orthodox Theological Tradition. In BÖHNKE, Michael - KATTAN, Assaad Elias OBERDORFER, Bernd (Eds.): Die Filioque-Kontroverse: historische, ökumenische und dogmatische Perspektiven 1200 Jahre nach der Aachener Synode. Freiburg - Basel Wien, Herder, 2011.

STIREWALT 1993

STOURAITIS 2014

STOURAITIS 2017

STOURAITIS 2018
StIREWALT, Luther M. Jr.: The Uses and Development of Greek Letter-Writing through the Second Century C. E. In StiRewalt, Luther M. Jr.: Studies in Ancient Greek Epistolography. Scholars Press, Atlanta, Georgia, 1993, pp. 1-26.

StOURAITIS, Ioannis: Roman Identity in Byzantium: A Critical Approach. BZ 107/1 (2014), pp. 175-220.

StOURAITIS, Ioannis: Reinventing Roman Ethnicity in High and Late Medieval Byzantium. Medieval Worlds Comparative \& Interdisciplinary Studies, no. 2017/5 (n.d.), pp. 70-94.

STOURAITIS, Ioannis: Byzantine Romanness: From Geopolitical to Ethnic Conceptions. In POHL, W. Gantner, Cl. - Grifoni, C. - Pollheimer, M. (Eds.): Transformations of Romanness in the Early Middle Ages: Early Medieval Regions and Identities (Millennium Studies 71). Berlin, De Gruyter, 2018, pp. 123-139.

StOWERS, Stanley K.: Letter Writing in Greco-Roman Antiquity. Philadelphia, Westminster Press, 1986, pp. 1726. 
SYKUTRIS 1930

SYKUTRIS 1932

SYROS 2010

TALBOT 1991

TINNEFELD 1972

TINNEFELD 1979

TINNEFELD 2010
SYKUTRIS, I.: Epistolographie, in: Real-Encyclopedie der classischen Altertumswissenschaft, Suppl. 5. Stuttgart 1930, pp. 185-220.

SYKUTRIS, I.: Probleme der byzantinischen Epistolographie. In: Orlandos, A. C. (Ed.): Actes du IIIme Congrès International d'Études Byzantines (session d'Athènes, octobre 1930). Athènes, 1932, pp. 295-310.

Syros, Vasileios: Between Chimera and Charybdis: Byzantine and Post-Byzantine Views on the Political Organization of the Italian City-States. Journal of Early Modern History 14 (2010), pp. 451-504.

TALBOT, Alice-Mary: Metochion In Kazhdan, Alexander - TAlbot, Alice-Mary (Eds.): The Oxford Dictionary of Byzantium, New York-Oxford, Oxford University Press, 1991, pp. 1356-1357.

TINNEFELD Franz: Georgios Philosophos. Ein Korrespondent und Freund des Demetrios Kydones. OCP 28 (1972), pp. 141-171.

TinNEFELD, Franz: Das Niveau der abendländischen Wissenschaft aus der Sicht gebildeter Byzantiner im 13. und 14. Jahrhundert. BF, no. 6 (1979), pp. 241-80.

TINNEFELD, Franz: Die Briefe des Demetrios Kydones. Themen und literarische Form. Mainzer Veröffentlichungen zur Byzantinistik 11 (Hrsg. Günter Prinzing). Harrasowitz Verlag, Wiesbaden, 2010. 
THORN-WICKERT 2006

PLP

TSIRPANLIS 1978

TURNER 1965

VERRYCKEN 2001

WEISS 1955

WEISS 1969

WEST 1974
THORN-WICKERT, Lydia: Manuel Chrysoloras (ca. 13501415). Bonner Romanistische Arbeiten 92. Frankfurt am Main, Peter Lang, 2006.

TRAPP, Erich - RAINER, Walther - Beyer, Hans-Veit (Eds.) Prosopographisches Lexikon Der Palaiologenzeit. CD-ROM Version. Wien, Verlag der Österreichischen Akademie der Wissenschaften, 2001.

TSIRPANLIS, Constantine N.: John Eugenicus and the Council of Florence. Byzantion 48 (1978), pp. 264-274.

TURNER, C. J. G.: Another Anti-Latin Work Attributed to Gennadius Scholarius. BZ 58 (1965), pp. 337-347.

VerRYCKEn, Koenraad: La Métaphysique d'Ammonius chez Zacharie de Mytilène. Revue des Sciences philosophiques et théologiques, Avril 2001, Vol. 85, No. 2 (Avril 2001), pp. 241-266.

WEISS, Roberto: Iacopo Angeli da Scarperia. In Medieval and Humanist Greek. Collected Essays by Roberto Weiss. Padova, Editrice Antenore, 1977, pp. 255-277 [First published in Medioevo e Rinascimento. Studi in onore de Bruno Nardi, II, 1955, Firenze, pp. 803-817].

WEISS, Günter: Joannes Kantakuzenos - Aristokrat, Staatsmann, Kaiser und Mönch - in der Gesellschaftsentwicklung von Byzanz im 14. Jahrhundert (Schriften zur Geistesgeschichte des östlichen Europas 4.) Harrassowitz, Wiesbaden, 1969.

WeSt, Martin: Iambus. In WeST, Martin: Studies in Greek Elegy and Iambus. In DöRRIE, Heinrich - MORAuX, Paul 
(Eds.): Untersuchungen zur antiken Literatur und Geschichte. Band 14. Berlin - New York, De Gruyter, 1974, pp. 22-39.

WOLFF 1948

WoLfF, Robert Lee: The Organization of the Latin Patriarchate of Constantinople, 1204-1261: Social and Administrative Consequences of the Latin Conquest. In Traditio VI (1948), pp. 33-60.

ZAKYTHINOS 1953

ZAKYThinos, D. A.: Le despotat grec de Morée II (Athens, 1953).

ZAKYTHINOS 1957

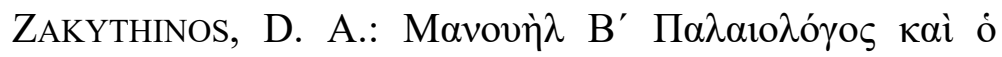

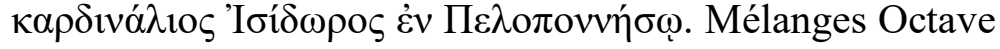
et Melpo Merlier, III (=Collection de 1'Institut Francaiş d'Athènes 94 (1957), pp. 45-69. 